\title{
Development of a Basic Biosensor System for Wood Degradation using Volatile Organic Compounds
}

\author{
Dissertation \\ In Partial Fulfilment of the Requirements for the Degree \\ Doctor of Philosophy (PhD) \\ of the Faculty of Forest Sciences and Forest Ecology \\ Georg-August-University Göttingen
}

submitted by

Prodpran Thakeow

born on $20^{\text {th }}$ August 1973, Chiangkham, Phayao, Thailand

Göttingen, 2008 
D7

$1^{\text {st }}$ examiner: Prof. Dr. Stefan Schütz

$2^{\text {nd }}$ examiner: Prof. Dr. Ursula Kües

$3^{\text {rd }}$ examiner: Prof. Dr. Reiner Finkeldey

Date of oral examination: 13 $3^{\text {th }}$ March 2008 


\section{ABSTRACT}

Wood inspection and durability testing of wood against microorganisms, as fungi, play an important role in forestry and wood-related material industries. An efficient testing method is required in order to facilitate inspections and to provide the accurate and precise assessment process. Monitoring volatile organic compounds (VOCs) released from wood substrates and from fungal metabolisms are marker compounds of the wood condition, i.e., indicating the type and stage of fungal infection. Insect antennae, which are recognised for their high sensitivity and selectivity in odour perception, are an alternative method for wood testing. On the basis of intact insect antenna biosensor it is possible to monitor wood released VOCs with high selectivity. This technique can be a complement to the traditional wood testing methods, providing a high throughput and non-destructive method.

This work was begun with the investigation of VOCs released from four different types of samples with gas chromatography-mass spectrometry. Firstly, VOCs from beech wood (Fagus sylvatica) infected with three wood rotting fungi; Trametes versicolor, Poria placenta, and Gloeophyllum trabeum were analysed. These fungi are commonly used in the durability testing of wood against microorganisms. The VOCs released from the fungal-infected beech showed species specific volatile patterns. The volatiles were grouped to five- and to eight- carbon (C5-C8) containing compounds and terpenoids. 1-Octen-3-ol, 3-octanone, and 3-octanol (C8-compounds) were commonly present in all samples, while terpenoids were species specific. $\alpha$ - and $\beta$-Barbatene were characteristic of $T$. versicolor-infected beech, protuillud-6-ene was characteristic of G. trabeum-infected beech, and daucene was characteristic of $P$. placenta-infected beech. Secondly, VOCs released from the minimally insect-colonised fruiting body $(<10 \%)$ and fully insect-colonised fruiting body $(\sim 100 \%)$ of Trametes gibbosa were identified. The minimally insect-colonised fruiting body released 1octen-3-ol, the typical fungal odour, at almost 20 times higher than in fully insectcolonised fruiting body. Thirdly, VOCs released during the fruiting body development of the ink-cap Coprinopsis cinerea, from the stage of mycelium to fruiting body autolysis, were studied. VOCs patterns of $C$. cinerea were specifically altered by the developmental stages. 
1-Octen-3-ol and 3-octanone were largely released during primodia formation and were gradually reduced in amount in later developmental stages. The terpenoids $\beta$ himachalene and cuparene drastically increased when the $C$. cinerea stipe elongated and became mature. Finally, the volatiles released during fruiting bodies autolysis of $C$. cinerea and other two ink-cap decomposing fungi (Coprinus comatus, Coprinopsis atramentaria), were investigated. In all three cases, $\mathrm{N}$-containing and S-containing compounds were additionally released during the autolytic stage.

The fungivorous beetle Cis boleti (Coloptera: Ciidae) and the fungal associated fly Suillia mikii (Diptera: Heleomizydae) were chosen for examining their olfactory perception since their life cycles are strongly related to fungi. For instance, $C$. boleti preferentially colonises fungi from the genus Trametes and S. mikii purposely land on the ink-cap fungi at a specific developmental stage. Gas chromatography-mass spectrometry with parallel electroantennographic detection was employed to demonstrate that both insect species are able to perceive the typical fungal odour 1-octen-3-ol with high selectivity and sensitivity. In addition, behavioural tests of $C$. boleti showed that this insect is able to discriminate the enantiomers of 1-octen-3-ol, where the female beetles were significantly more attracted to the $(S)-(+)$ enantiomer at lower doses than male beetles. The fly $S$. mikii reproducibly responded to the VOCs 1-undecene, 2-butanone, and dimethyl trisulfide, released from the autolysis fruiting bodies of the ink-cap fungi.

The C. boleti antenna perceived the typical fungal odour, 1-octen-3-ol, with high selectivity and sensitivity of down to $5 \mathrm{ng} \mathrm{ml}^{-1}$ in air. The antenna life time lasted up to one day. Consequently, as a proof of principle C. boleti antenna was used as a biocomponent in a biosensor system for testing beech wood samples infected by $T$. versicolor. The biosensor system using the superposition method in combination with a recalibration system was adopted. In this configuration C. boleti antenna yielded reproducible responses to the fungal marker volatile compound released from fungalinfected beech wood.

Altogether these results lead to a promising possibility to set up a biosensor based on intact antenna as a highly sensitive and selective testing method for wood durability against decay fungi. 


\section{KURZFASSUNG}

Die Prüfung von Holz und ein Test seiner Beständigkeit gegen Mikroorganismen wie Pilze spielen eine wichtige Rolle in der Forstwirtschaft und der holzverarbeitenden Industrie.

Um solche Prüfungen zu erleichtern und präzise Bewertungen zu ermöglichen, ist eine effiziente Testmethode erforderlich. Flüchtige organische Verbindungen (volatile organic compounds VOCs), die vom Holzsubstrat und vom pilzlichen Metabolismus erzeugt werden, sind Marker für den Zustand des Holzes, d.h. sie zeigen Art und Stadium einer Pilzinfektion an. Insektenantennen, die für ihre hohe Sensitivität und Selektivität in der Duftwahrnehmung bekannt sind, stellen eine alternative Methode zur Holzprüfung dar. Ein Biosensor auf der Basis intakter Insektenantennen ermöglicht es, vom Holz freigesetzte VOCs mit hoher Selektivität nachzuweisen. Diese Methode kann eine Ergänzung zu den traditionellen Prüfverfahren darstellen und bietet einen hohen Probendurchsatz sowie ein zerstörungsfreies Verfahren.

Als Beginn dieser Arbeit wurden die VOCs verschiedener Proben mit Gaschromatographie-Massenspektroskopie untersucht. Zuerst wurden die VOCs von Buchenholz (Fagus sylvatica) analysiert, das mit drei holzzersetzenden Pilzen (Trametes versicolor, Poria placenta und Gloeophyllum trabeum) infiziert war. Diese Pilze werden häufig verwendet, um die Beständigkeit von Holz gegen Mikroorganismen zu testen. Die vom pilzinfizierten Buchenholz freigesetzten VOCs zeigten artspezifische Muster. Die Volatile lassen sich gruppieren in Stoffe mit fünf bis acht Kohlenstoffen (C5-C8) sowie Terpenoide. 1-Octen-3ol, 3-Octanon und 3-Octanol (C8-Verbindungen) waren allgemein in allen Proben enthalten, während Terpenoide artspezifisch auftraten. $\alpha$ - und $\beta$-Barbaten waren charakteristisch für eine Infektion mit T. versicolor, Protuillud-6-en war charakteristisch für G. trabeum und Daucen war charakteristisch für $P$. placenta.

Als Zweites wurden VOCs identifiziert, die von verschiedenen Stadien von Trametes gibbosa mit schwacher bis vollständiger Kolonisierung durch den Käfer Cis boleti freigesetzt wurden. Die schwach besiedelten Fruchtkörper setzten den typischen Pilzduftstoff 1-Octen3-ol in fast zwanzigfach höherer Menge frei als vollständig besiedelte Fruchtkörper. 
Als Drittes wurden die VOCs untersucht, die während der Fruchtkörperentwicklung vom Stadium des Myceliums bis zur Autolyse von Coprinopsis cinerea freigesetzt werden. Die VOCMuster von $C$. cinerea änderten sich spezifisch mit den Entwicklungsstadien. 1-Octen-3-ol und 3-Octanon zeigten während der Bildung der Primodia eine starke Freisetzung, die in späteren Stadien abnahm. Die Terpenoide $\beta$-Himachalen und Cuparen wurden während Wachstum und Reifung des Stängels von $C$. cinerea drastisch erhöht.

Zum Abschluss wurden die autolytischen Fruchtkörper der Tintlinge Coprinus comatus, Coprinopsis atramentaria und C. cinerea untersucht. Als zusätzliche Stoffe wurden hier stickstoffund schwefelhaltige Verbindungen freigesetzt.

Der fungivore Käfer Cis boleti (Coloptera: Ciidae) und die pilzassoziierte Fliege Suillia mikii (Diptera: Heleomizydae) wurden ausgewählt, um ihre geruchliche Wahrnehmung zu untersuchen, da ihre Lebenszyklen einen starken Bezug zu Pilzen haben. Zum Beispiel kolonisiert C. boleti vorzugsweise Pilze der Gattung Trametes und S. mikii landen gezielt auf Tintlingen in spezifischen Entwicklungsstadien. Gaschromatographie-Massenspektrometrie mit paralleler elektroantennographischer Detektion (EAD) wurde eingesetzt, um zu demonstrieren, dass beide Insektenarten in der Lage sind, den typischen Pilzgeruchsstoff 1Octen-3-ol mit hoher Selektivität und Sensitivität nachzuweisen. Zusätzlich zeigten Verhaltenstests, dass C. boleti in der Lage ist, die Enantiomere von 1-Octen-3-ol zu unterscheiden, wobei weibliche Käfer signifikant stärker vom $(S)-(+)$-Enantiomer angelockt wurden und dies schon bei geringeren Konzentrationen als die männlichen Käfer. Die Fliege S. mikii reagierte in EAD-Tests reproduzierbar auf die VOCs 1-Undecene, 2-Butanon und Dimethyl-Trisulfid, die bei der Autolyse der Fruchtkörper von Tintlingen freigesetzt werden.

Die Antennen von $C$. boleti detektierten den typischen Pilzgeruch 1-Octen-3-ol mit hoher Selektivität und Sensitivität bis zu einer Konzentration von $5 \mathrm{ng} \mathrm{ml}^{-1}$ in Luft. Die Lebensdauer der Antennen betrug bis zu ein Tag. Als grundlegender Test wurden Antennen von $C$. boleti als Biokomponenten eines Biosensorsystems benutzt, um Buchenholzproben mit Infektion durch T. versicolor zu untersuchen. Dazu diente ein Biosensorsystem, das auf der Überlagerungsmethode in Verbindung mit einem Rekalibrierungssystem basiert. In dieser Konfiguration lieferten die Antennen von C. boleti 
reproduzierbare Reaktionen auf die pilzlichen Markerstoffe, die von pilzinfiziertem Buchenholz freigesetzt werden.

Zusammengefasst führen diese Ergebnisse zu einer aussichtsreichen Möglichkeit, einen Biosensor auf Basis von intakten Antennen als hoch empfindliche und selektive Testmethode für die Holzbeständigkeit gegen zersetzende Pilze zu entwickeln. 


\section{RIASSUNTO}

Il controllo delle qualità del legno e della sua durevolezza contro diverse specie di microrganismi e funghi cariogeni riveste un ruolo importante nelle scienze forestali e nelle industrie che trattano materiale legnoso. Vi è perciò la necessità di sviluppare un metodo efficiente che faciliti i controlli e fornisca un processo accurato e preciso di valutazione della qualità del legno. I composti organici volatili (VOCs) che si originano dai substrati legnosi e dal metabolismo dei fungi può rilevare il processo di degradazione in corso, indicando la specie di fungo e la fase di infezione. Le antenne degli insetti possono rappresentare un metodo alternativo per il monitoraggio della qualità del legno, avendo un'alta sensibilità e selettività nella percezione di composti volatili. Attraverso l'utilizzo di biosensori che impieghino le antenne degli insetti come biocomponenti è possibile identificare i VOCs rilasciati da materiale legnoso con alta selettività. Questa nuova tecnica potrebbe essere di complemento ai metodi di controllo tradizionali, fornendo uno strumento efficacie e un non distruttivo.

Questo lavoro di tesi è stato avviato con un'indagine sui VOCs rilasciati da tre differenti campioni di legno utilizzando la gascromatografia -spettrometria di massa. In primo luogo, sono stati analizzati i VOCs rilasciati dal legno di faggio (Fagus sylvatica) precedentemente infettato con i funghi cariogeni: Trametes versicolor, Poria placenta e Gloeophyllum trabeum. Questi funghi sono comunemente usati in laboratorio per le prove di durevolezza del legno contro i microorganismi. I VOCs rilasciati dal legno di faggio infettato hanno mostrato la presenza di pattern specie-specifici. I volatili ritrovati sono stati raggruppati in: composti con cinque o otto atomi di carbonio (C5-C8) e composti terpenici. L'1-otten-3-olo, il 3-ottanone e il 3ottanolo (composti C8) sono stati ritrovati in tutti i campioni testati, mentre i composti terpenici sono risultati specifici della specie infettante. Nel legno di faggio infettato con $T$. versicolor erano presenti specificatamente l' $\alpha$ - e il $\beta$-barbatene, mentre il protuillud-6-ene è caratteristico di campioni infettati con $G$. trabeum e il daucene in campioni infettati con $P$. placenta.

Secondariamente sono stati analizzati i VOCs liberati dai carpofori del fungo Trametes gibbosa distinguendo fra carpofori colonizzati in minima parte $(<10 \%)$ o completamente 
$(\sim 100 \%)$ da insetti fungivori. I carpofori con un basso tasso di colonizzazione rilasciavano l'1-otten-3-olo -il tipico odore di fungo- ad un tasso quasi 20 volte superiore rispetto ai carpofori colonizzati completamente.

In terzo luogo, è stata studiata l'emissione dei VOCs durante le diverse fasi di sviluppo del fungo dell'inchiostro Coprinopsis cinerea, iniziando dalla fase di micelio fino alla fase di autolisi dei carpofori. I pattern di VOCs nelle diverse fasi di sviluppo hanno mostrato specifiche variazioni.L'1-otten-3-olo e il 3-ottanone sono rilasciati in grande quantità durante la formazione dei primordi e gradualmente diminuiscono nelle fasi successive. I terpenoidi $\beta$ himachalene e cuparene aumentano drasticamente nella fase di allungo dei gambi di $C$. cinerea e nella fase di maturazione dei carpofori. Infine, i composti volatili dei carpofori di $C$. cinerea, Coprinus comatus e Coprinopsis atramentaria, sono stati analizzati durante la fase terminale di autolisi. Caratteristici di questa fase sono composti contenenti azoto e composti contenenti zolfo che vengono rilasciati in aggiunta ai composti già descritti .

L'insetto fungivoro Cis boleti (Coloptera: Ciidae) e il dittero Suillia mikii (Diptera: Heleomizydae) sono stati scelti per esaminare la loro percezione olfattiva in quanto i loro cicli di vita sono fortemente collegati con diverse specie di funghi. Per esempio, C. boleti colonizza preferenziale i funghi del genere Trametes e S. mikii è attratta dai funghi dell'inchiostro (per esempio Coprinus) in una fase specifica dello sviluppo del carpoforo. Combinando la gascromatografia - spettrometria di massa con la rilevazione parallela dell'elettoantennografia è stato dimostrato che entrambe le specie percepiscono l'odore 1otten-3-olo con alta selettività e sensibilità. Le prove comportamentali successive utilizzando C. boleti hanno dimostrato che gli adulti di questa specie riescono a discriminare i due enantiomeri dell'1-otten-3-olo, dove le femmine sono sensibilmente più attratte verso l'enantiomero (S)-(+) a dosi più basse rispetto ai maschi. Il dittero $S$. mikii ha fornito risposte elettroantennografice riproducibili ai VOCs: 1-undecene, 2-butanone e dimetiltrisolfuro. Questi composti sono rilasciati dai carpofori del fungo dell'inchiostro in fase autolitica. Le antenna di C. boleti riescono a percepire l'1-otten-3-olo con alta selettività e una bassissima soglia fino a una concentrazione di $5 \mathrm{ng} / \mathrm{ml}$ d'aria. Inoltre le antenne di C. boleti rimangono vitali per la durata di un giorno dopo essere state recise dal corpo dell'insetto. Conseguentemente, le antenne di C. boleti sono state utilizzate come parte di un biosensore 
allo scopo di verificare il grado d'infezione fungina in campioni di faggio infettati con $T$. versicolor. Per questo esperimento è stato utilizzato un biosensore che addotta il metodo della superposizione congiuntamente ad un sistema di ricalibratura. In questa configurazione le antenne di C. boleti hanno generato risposte riproducibili all'1-otten-3-olo rilasciato dal legno di faggio infetto.

In conclusione, questi risultati dimostrano la promettente possibilità di utilizzo di biosensori basati sulle antenne degli insetti come metodi di analisi altamente sensibili e selettivi per controllare la durevolezza del legno contro funghi cariogeni. 


\section{บทคัดย่อ}

การตรวจสอบและการทดสอบความคงทนของไม้ที่มีต่อจุลินทรีย์ เช่น เชื้อรา เป็นส่วนที่สำคัญสำหรับ อุตสาหกรรมป่าไม้และอุตสาหกรรมที่ใช้ไม้ ด้วยเหตุนี้ จึงมีความจำเป็นอย่างยิ่งที่ต้องมีวิธีการทดสอบที่มี ประสิทธิภาพที่สามารถทำให้การตรวจสอบทำได้ง่าย มีความถูกต้องและแม่นยำ การเฝ้าติดตามสารระเหย อินทรีย์ (volatile organic compounds; VOCs) ที่ปลดปล่อยออกมาจากไม้และจากกระบวนการเมตา บอลิซึมของเชื้อราสามารถบ่งชี้สภาวะของไม้ได้ ยกตัวอย่างเช่น แสดงถึงสภาวะของการย่อยสลายของไม้ โดยเชื้อราและชนิดของเชื้อรา การติดตาม VOCs ที่ปลดปล่อยออกมาจากไม้โดยใช้ไบโอเซนเซอร์ สามารถใช้เป็นวิธีทางเลือกอีกทางหนึ่งสำหรับการทดสอบไม้ โดยมีหนวดของแมลงในสภาพที่สมบูรณ์เป็น ส่วนสำคัญของไบโอเซนเซอร์ เนื่องจากหนวดของแมลงมีความไวและความเฉพาะเจาะจงสูงต่อการรับกลิ่น วิธีการทดสอบนี้จะเป็นวิธีการทดสอบที่รวดเร็วและเป็นวิธีการทดสอบที่ไม่เกิดการทำลาย ซึ่งสามารถเติม เต็มวิธีการทดสอบไม้ที่ใช้ในปัจจุบัน

งานวิจัยนี้ ได้เริ่มจากการสำรวจ VOCs ที่ปลดปล่อยออกมาจากเชื้อรา 3 ชนิด โดยใช้เทคนิคแกสโคร มาโตรกราฟีแมสสเปคโตรเมทรี ในขั้นตอนแรกได้ทำการวิเคราะห์ VOCs ที่ปลดปล่อยจากไม้บีช (Fagus sylvatica) ที่ถูกทำลายโดยเชื้อราทำลายไม้ 3 ชนิด ได้แก่ ทราเมเทส เวอร์สิคัลเลอร์ (Trametes versicolor) พอเรีย พลาเซนทา (Poria placenta) และ กลอเอโอฟีลลุม ทราเบอุม (Gloeophyllum trabeum) ซึ่งเชื้อราเหล่านี้เป็นเชื้อรามาตรฐานที่ใช้ทดสอบความคงทนของไม้ จากการทดสอบพบว่า $\mathrm{VOCs}$ ที่ปลดปล่อยออกมาจากไม้บีชที่ถูกทำลายด้วยเชื้อราทั้ง 3 ชนิด มีรูปแบบของ VOCs ที่ เฉพาะเจาะจง ซึ่ง $\mathrm{VOCs}$ เหล่านั้นสามารถจัดกลุ่มได้เป็น สารประกอบที่ประกอบด้วยคาร์บอน 5 ถึง 8 อะตอม และสารประกอบเทอร์พีนอยด์ สารประกอบที่มีคาร์บอน 8 อะตอม ได้แก่ สาร 1 -อ๊อกเทน-3-ออล 3-อ๊อกทาโนน และ 3-อ๊อกทานอล ปรากฏในทุกตัวอย่างที่ทดสอบ ในขณะที่สารประกอบเทอร์พีนอยด์ ขึ้นอยู่กับชนิดของเชื้อรา โดยที่ อัลฟา- และ เบทา-บาร์บาทีนเป็นสารที่ปลดปล่อยจากไม้บีชที่ถูกทำลาย โดยเชื้อ T. versicolor สารโปรทูอิลลูด-6-อีนเป็นสารที่ปลดปล่อยจากไม้บีชที่ถูกทำลายโดยเชื้อ $G$. trabeum และเดาซีนเป็นสารที่ปลดปล่อยจากไม้บีชที่ถูกทำลายโดยเชื้อ P. placenta ในขั้นตอนที่สอง ได้ ทำการวิเคราะห์และแยกแยะ VOCs ที่ปลดปล่อยจากดอกเห็ด ทราเมเทส จิบโบซา (Trametes gibbosa) ที่ถูกอาศัยโดยแมลงแบบบางส่วน (น้อยกว่าร้อยละ 10) และแบบทั้งหมด (ประมาณร้อยละ 100) พบว่าดอกเห็ดที่ถูกอาศัยแบบบางส่วนจะปลดปล่อยสาร 1 -อ๊อกเทน-3-ออล ซึ่งเป็นสารเฉพาะ สำหรับเชื้อรา ในปริมาณสูงเกือบ 20 เท่าสูงกว่าดอกเห็ดที่ถูกอาศัยแบบทั้งหมด ในขั้นตอนที่สาม ได้ศึกษา VOCs ที่ปลดปล่อยระหว่างการเจริญเติบโตของเชื้อราโคพรินอพซีส ซินเนเรีย (Coprinopsis cinerea) 
ตั้งแต่ไมเซเลียมไปจนถึงขั้นตอนการพัฒนาเป็นดอกเห็ด พบว่ารูปแบบของ VOCs มีความเฉพาะเจาะจง กับช่วงระยะเวลาของการเจริญเติบโตโดยในช่วงการเกิดไพรมอร์เดียมีการปลดปล่อย 1 -อ๊อกเทน-3-ออล และ 3-อ๊อกทาโนน ในปริมาณมาก แต่ปริมาณของสารทั้งสองจะลดลงในช่วงเวลาการเจริญต่อๆ ไป ใน ขณะเดียวกันพบว่า สารประกอบเทอร์พีนอยด์ ฮิมาชาลีนและคูพารีน มีการเพิ่มขึ้นอย่างมาก เมื่อ $C$. cinerea ในช่วงยืดก้านดอกเห็ดและช่วงที่มีการเจริญเติบโตอย่างเต็มที่ ในขั้นตอนสุดท้าย ได้ทำการ ตรวจสอบเห็ดน้ำหมึกในช่วงที่เกิดการย่อยสลายตัวเอง เห็ดเหล่านั้นได้แก่ โคพรินุส โคมาทุส (Coprinus comatus) โคพรินอพซิส อาทราเมนทาเรีย (Coprinopsis atramentaria) และ C. cinerea พบว่าในช่วง ที่เกิดการย่อยสลายตัวเองมีการปลดปล่อยสารประกอบที่มีไนโตรเจนและซัลเฟอร์เป็นองค์ประกอบ

ทำการศึกษาการได้รับกลิ่นของแมลง โดยได้ทำการเลือกแมลงที่วงจรชีวิตขึ้นอยู่กับเชื้อรา ซิส โบเลทิ (Cis boleti) และ แมลงที่มีวงจรชีวิตเกี่ยวเนื่องกับเชื้อรา ซูอิลเลีย มิคิอิ (Suillia mikiz) เนื่องจากแมลง เหล่านี้มีวงจรชีวิตที่มีความเกี่ยวพันกับเชื้อราอย่างชัดเจน จะเห็นได้จาก C. boleti จะเลือกใช้วงจรชีวิต อยู่ในเห็ดชนิดทราเมเทส และ $S . m i k i i$ เลือกที่จะไปเกาะเห็ดน้ำหมึกในช่วงการเจริญที่เฉพาะเจาะจง สำหรับการศึกษาการได้รับกลิ่นของแมลง ได้ใช้เทคนิคแกสโครมาโตรกราฟีแมสสเปคโตรเมทรี ควบคู่กับ อีเลคโทรแอนเทนโนกราฟิคดีเทคชัน เพื่อแสดงให้เห็นว่าแมลงทั้ง 2 สปีชีส์ สามารถรับกลิ่นเฉพาะของเชื้อ รา (1-อ๊อกเทน-3-ออล) ได้อย่างมีประสิทธิภาพและมีความเฉพาะเจาะจงสูง นอกเหนือจากนี้ การทดสอบ เชิงพฤติกรรมของ $C$. boleti แสดงให้เห็นว่า แมลงชนิดนี้สามารถแยกแยะอีแนนที่อเมอร์ของ 1-อ๊อกเทน3 -ออล ได้ โดยที่แมลงตัวเมียแสดงความสนใจอย่างมีนัยสำคัญ ต่อ $(S)-(+)$ enantiomer ที่ความ เข้มข้นต่ำ มากกว่าแมลงตัวผู้ ส่วนแมลง $S . m i k i i$ มีการตอบสนองต่อ 1 -อุนเดซีน 1 -บิวทาโนนและได เมทิลไตรซัลไฟด์ ที่ปลดปล่อยจากเห็ดน้ำหมึกในสภาวะที่เกิดการย่อยตัวของมันเอง

หนวดของ $C$. boleti สามารถรับกลิ่นเฉพาะของเชื้อรา (1-อ๊อกเทน-3-ออล) ด้วยความไวและ เฉพาะเจาะจงในปริมาณที่ต่ำถึง 5 นาโนกรัมต่อมิลลิลิตร ในอากาศ และอายุการใช้งานของหนวดนานถึง 1 วัน เพื่อเป็นการพิสูจน์ถึงความสามารถที่จะใช้หนวดของ C. bolet $i$ เป็นส่วนหนึ่งของระบบไบโอเซนเซอร์ โดยการติดตามจาก VOCs ในการทดสอบไม้ที่ถูกย่อยสลายด้วยเชื้อรา $T$. versicolor โดยที่ระบบ ไบโอเซนเซอร์นี้ใช้วิธีการซุปเปอร์โพสิชัน (superposition method) และระบบรีแคลิเบรซัน (recalibration system) เพื่อแสดงการตอบสนองของหนวดแมลงต่อ VOCs จากการทดลอง หนวด ของ C. boleti มีการตอบสนองอย่างสม่ำเสมอต่อสารระเหยที่เป็นตัวบ่งชี้ของไม้บีชที่ถูกย่อยสลายด้วยเชื้อรา จากผลการทดลองข้างต้นนำไปสูความเป็นไปได้ที่จะสร้างไบโอเซนเซอร์ไดยใช้หนวดที่สมบูรณ์ของแมลง เป็นตัวตรวจจับ วิธีการทดสอบนี้มีความไวและความเฉพาะเจาะจงสูงสำหรับการทดสอบความคงทนของไม้ ที่มีต่อเชื้อรา 


\section{ACKNOWLEDGEMENTS}

I would like to express my gratitude to my supervisor, Prof. Dr. Stefan Schütz for giving me an opportunity to join the chemical ecology world and to learn how to make use of that. Moreover, I would like to thank for his idea, advice, encouragement, and kindness throughout my PhD studying. I would like to thank Prof. Dr. Ursula Kües for giving comments and suggestion on my dissertation, being an examiner of my $\mathrm{PhD}$ defense, providing me a chance to contribute to her textbook, and involving me to a "Frauenbeauftragte" group. I am thankful to Prof. Dr. Reiner Finkeldey for undertaking the examination of my work.

I would like to thank Dr. Bernhard Weißbecker for all laboratorial and technical support. I would like to thank Frau Ulrike Eisenwiener and Frau Miriam Rameckers for teaching and assisting me on laboratory works. I would like to thank Frau Kirstin Kosanke-Schütz for a systematic working on the biosensor system. I would like to thank Frau Kira Dunteman, Frau Sigrid Warzecha, Herr Reinhold Dankworth, Herr Jörg Berger, Herr Wolfgang Tambour and Herr Stefan Rath for their kindness in technical assistance. I am also thankful for Frau Elizabeth Wandt and Frau Brunhilde Brunotte for their help in bureaucracy.

I would like to thank Prof. Dr. Uwe Koch for his clear lecture on EAG system in Kaiserslautern. I would like to thank Dr. Norbert Menke and Dr. Pavel Plašil for insect identification and to Dr. Holm Frauendorf for enantiomer identification. I would like to give my thanks to Wassana Chaisaena for her kind cooperation in working on Coprinopsis.

I would like to thank to Dr. Ernst Kürsten for his kind coordination of the $\mathrm{PhD}$ program in Wood Biology and Technology and his hospitality.

I am indebted to the Royal Thai Government and ChiangMai University for providing the financial support throughout my PhD studying. I would like to thank COST Action E37 committee and ECRO for granting. 
Thanks to all of you for sharing knowledge and nice time during studying, Bettina Johne, Sonja Weissteiner, Marta Paczkowska, Maria Vlaic, Gerrit Holighaus, Julian Heierman, Hu Jiafu, Sebastian Paczkowski, Matthias Schulz, and Martin Scholz.

Thanks for all Thai friends for making Germany not too far from Thailand.

I would like to give my innermost thanks to my mother, my father, and my sister and her family for their tireless assistance, encouragement, and endless love.

I would like to give my special thank to Dr. Sergio Angeli for his laboratorial and technical support and scientific inspiration. My dissertation would not be nicely accomplished without your drive and great effort. Thanks to mio Angelo for being beside me in any difficult moments and filling my life with love. I am happy that I know you. 


\section{CONTENTS}

Abstract $\quad$ i

Acknowledgements $\quad$ xi

Contents $\quad$ xiii

Chapter 1 General introduction 1

1.1. Introduction 3

1.2. Wood testing 3

1.3. Volatile organic compounds 4

1.3.1. Volatile sampling $\quad 7$

1.3.2. Volatile analysis $\quad 8$

1.4. Insect olfaction 10

1.5. Electroantennography (EAG) 16

1.6. Biosensors 19

1.7. Purposes of this study 24

1.8. References 25

Chapter 2 Volatile organic compounds for wood assessment 31

2.1. Introduction $\quad 33$

2.2. Volatiles released by living trees 34

2.3. Volatiles released by trunks and deadwood 37

2.4. VOCs emitted by wood and wood products $\quad 40$

2.5. Volatile released by fungi 41

2.6. Volatiles released by fungus-infested wood 47

2.7. Sick building syndrome (SBS) as a consequence of VOCs 49

2.8. What is the role of VOCs for insects? 50

2.9. VOCs mediating insect interaction with trees, wood and fungi 51

2.10. Techniques for assessing wood quality on the basis of VOCs

2.11. Outlook

60

Chapter 3 Monitoring of volatile organic compounds released from 73 fungal-infected wood

3.1. Abstract $\quad 75$

3.2. Introduction $\quad 76$

3.3. Materials and methods $\quad 76$

3.3.1. Fungal culture preparation $\quad 76$ 
3.3.2. VOC sampling

3.3.3. VOC analysis using gas chromatography and mass spectrometry (GC-MS)

3.4. Results

3.4.1. Fungal cultures

78

3.4.2. VOC analysis

3.5. Discussion

3.6. References

Chapter 4 Monitoring of volatile organic compounds released from

\section{Coprinopsis cinerea fruiting body development}

4.1. Abstract

4.2. Introduction

4.3. Materials and methods

4.3.1. C. cinerea strain 93

4.3.2. Culture preparation 93

4.3.3. Volatile sampling 94

4.3.4. Volatile analysis with gas chromatography-mass spectrometry (GC-MS) 95

4.3.5. Principle component analysis (PCA) 95

4.4. Results

4.4.1. C. cinerea culture

4.4.2. Principle component analysis (PCA) of $C$. cinerea volatiles

96

4.5. Discussion

98

4.6. References

Chapter 5 External antennal morphology and sensillar type 107 distribution of Cis boleti (Coleoptera: Ciidae)

5.1. Abstract 109

5.2. Introduction 110

5.3. Materials and methods 111

5.3.1. Insects 111

5.3.2. Scanning electron microscopy 111

5.3.3. Distribution of sensilla on the antennae 111

5.4. Results 112

5.4.1. Gross morphology of the antenna 112

5.4.2. Morphological sensillar types 113

5.4.3. Distribution of the sensillar types 115

5.5. Discussion $\quad 120$

5.6. References 121 
Chapter 6 Antennal and behavioural responses of Cis boleti to fungal odour of Trametes gibbosa

6.1. Abstract 125

6.2. Introduction $\quad 125$

6.3. Materials and methods $\quad 127$

6.3.1. Collection of fungi and insects 127

6.3.2. Extraction of T. gibbosa volatiles 127

6.3.3. T. gibbosa headspace analysis and emission rate of 1 $\begin{array}{ll}\text { octen-3-ol } & 128\end{array}$

6.3.4. Chemicals 128

6.3.5. GC-MS analysis 129

6.3.6. Identification and quantification of T. gibbosa volatiles 130

6.3.7. Electrophysiological measurements 131

$\begin{array}{ll}\text { 6.3.8. Behavioural test } & 132\end{array}$

6.4. Results 133

6.4.1. Volatile compounds of T. gibbosa extract 133

6.4.2. Electrophysiological response of $C$. boleti antennae to T. gibbosa volatiles 135

6.4.3. Behavioural test 138

6.5. Discussion 140

6.6. References 144

Chapter 7 Electroantennographic response of Suillia mikii to 147 volatiles released by autolytic Coprinus comatus, Coprinopsis cinerea and Coprinopsis atramentaria fruiting bodies

7.1. Abstract 149

7.2. Introduction $\quad 150$

7.3. Materials and methods $\quad 150$

7.3.1. Fungi and insects $\quad 150$

7.3.2. Analysis of C. comatus, C. atramentaria, and
C. cinerea volatile organic compounds

7.3.3. Electrophysiological response of $S$. mikii to
C. comatus, C. atramentaria, and $C$. cinerea volatiles

7.4. Results 153

7.4.1. Volatiles of C. comatus, C. atramentaria, and C. cinerea

7.4.2. Electrophysiological response of $S$. mikii fly to $C$. comatus, C. atramentaria, and C. cinerea volatile 154

7.3. Discussion

158

7.4. References 159 
Chapter 8 Fungivorous insect antenna as a biosensor for wood-rotting fungi

8.1. Abstract 165

8.2. Introduction 166

8.3. Materials and methods $\quad 167$

8.3.1. Cis boleti 167

8.3.2. Electrophysiological response of C. boleti to 1-octen-3-ol 167

8.3.3. Biosensor system 169

8.4. Results 171

8.4.1. Electrophysiological response of C. boleti to 1-octen-3-ol 171

8.4.2. C. boleti antennal response using the portable biosensor system 174

$\begin{array}{ll}\text { 8.5. Discussion } & 174\end{array}$

8.6. References 175

$\begin{array}{lll}\text { Chapter } 9 \quad \text { General discussion } & 179\end{array}$

9.1. General discussion 181

9.2. Volatile sampling techniques $\quad 182$

9.3. Identification of VOCs in fungi 183

9.4. Insect antennae as biocomponent in biosensors 186

9.6. Conclusion and future prospectives 189

9.7. References 190

\section{Curriculum vitae}




\section{ABBREVIATIONS}

CLSA Close loop stripping analysis

CSPs Chemosensory proteins

EAD Electroantennographic detector

EAG Electroantennography

FID Flame ionisation detector

GC-EAD Gas chromatograph coupled with electroantennographic detector

GC-MS Gas chromatograph coupled with mass spectrometer

GC-FID Gas chromatograph coupled with flame ionisation detector

HS-VOCs Headspace-VOCs

MVOCs Microbial volatile organic compounds

NIST National Institute of Standards and Technology

OBPs Odorant binding proteins

ODE Odorant degrading enzymes

ODP Olfactory detector port

PDMS Polydimethylsiloxane

PTFE Polytetrafluoroethylene

RH Relative humidity

SBS Sick building syndrome

SCR Sing cell recording

SEM Scanning electron microscopy

SIM Single ion monitoring

SPME Solid phase microextraction

TDS-CIS Thermodesorption system with cold injection system

TIC Total ion current

UMVOCs Unique microbial volatile organic compounds

VOCs Volatile organic compounds

YMG/T Yeast malt glucose/L-tryptophan 


\section{LISTS OF FIGURES}

Figure 1-1 Schematic drawing of three volatile sampling methods

Figure 1-2 Schematic drawing of a gas chromatograph-mass spectrometer/electroantennographic detector setup (GC$\mathrm{MS} / \mathrm{EAD})$

Figure 1-3 The "speciescape" illustrates the relative diversity of insects in relation to other species groups

Figure 1-4 Scanning electron micrograph of the adult head of the rust red flour beetle Tribolium castaneum (Coleoptera: Tenebrionidae)

Figure 1-5 Schematic representation of the sensory organs and peripheral nerves of an adult fly

Figure 1-6 Schematic representation of insect sensilla

Figure 1-7 Electroantennography

Figure 1-8 Schematic representation of a biosensor

Figure 1-9 Schematic drawing of the biosensor-system

Figure 2-1 Distribution of physiological decay states on beech trunk; grey to black patches: fresh to seriously decayed

Figure 2-2 VOC patterns released by differently decayed bark patches on a trunk of European beech

Figure 3-1 Examples of the chromatograms of fungal-infected beech wood after 1 -week inoculation

Figure 4-1 Volatile sampling method 
Figure 4-2 Fruiting body development of Coprinopsis cinerea

Figure 4-3 Principal component analysis (PCA) of Coprinopsis cinerea 97 volatiles

Figure 4-4 A gas chromatogram of volatiles released in day 6 (mature 98 fruiting body of Coprinopsis cinerea)

Figure 4-5 Alteration of 1-octen-3-ol, 3-octanone, $\beta$-himachalene and cuparene during Coprinopsis cinerea fruiting body development

Figure 5-1 Scanning electron micrographs of the antenna of a Cis boleti (Ciidae) adult

Figure 5-2 Sensilla trichodea Scanning electron micrographs

Figure 5-3 Sensilla basiconica Scanning electron micrographs

Figure 5-4 Sensilla coeloconica Scanning electron micrographs

Figure 5-5 Map representation of the distribution of four sensillar morphological categories found on the antennal surface of the adult of Cis boleti (Coleoptera: Ciidae)

Figure 6-1 Gas chromatography (GC) - electroantennographic detection (EAD) and mass spectrometer (MS) chromatograms of $C$. boleti response to 1-octen-3-ol in T. gibbosa fruiting body extract

Figure 6-2 EAG responses (mean $\pm \mathrm{SE}$ ) of $C$. boleti males and females to 1-octen-3-ol

Figure 6-3 Behavioural responses to 1-octen-3-ol enantiomers

Figure 7-1 Gas chromatogram (GC) - electroantennographic detection (EAD) and mass spectrogram (MS) of Suillia mikii fly to the volatiles of autolytic fruiting bodies.

xix 
Figure 8-1 Schematic of EAG system

Figure 8-2 An example of gas chromatography (CG) - mass spectrometry (MS)/electroantennographic detection (EAD) chromatograms of $C$. boleti (male) response to $5 \mathrm{ng}$ of 1 -octen-3-ol

Figure 8-3 Dose-response curves of male and female C. boleti to 1-octen-3ol

Figure 8-4 EAG responses (mean $\pm \mathrm{SE}$ ) of male and female C. boleti to 1octen-3-ol

Figure 9-1 The cycle wood-decaying fungi

Figure 9-2 Chemical oxidation of 3-methylbutan-1-ol and proposed biosynthetic relation of 3-methylbutan-1-ol, 3-methylbutanal, and 3-methylbutanoic acid at different stages of fungal development

Figure 9-3 General idea of using the diversity of insect antennae as biocomponents in biosensors.

Figure 9-4 Excised insect antennae placed in EAG antennal holder 


\section{LISTS OF TABLES}

Table 1-1 Examples of VOCs from different sources 6

Table 2-1 VOC classes as released by wood, infested wood, and microorganisms

Table 2-2 VOCs released from Tuber borchii fruiting bodies during ascus maturation

Table 2-3 Low molecular weight VOCs released from different types of fungi grown on $\mathrm{C}$ - and $\mathrm{N}$-rich media

Table 2-4 VOCs released by micro-organisms 48

Table 3-1 VOCs released from fungal-infected beech (Fagus sylvatica) 80

Table 4-1 Volatiles released during life cycle development of Coprinopsis 100 cinerea

Table 6-1 Volatile compounds of Trametes gibbosa identified by GC-MS in 134 fruiting body headspace and extract

Table 6-2 Electroantennographic responses of $C$. boleti antennae to Trametes gibbosa volatiles and standard compounds

Table 7-1 GC operating programs for volatiles sampled with CLSA and SPME methods

Table 7-2 Volatiles of the autolytic Coprinus comatus, Coprinopsis atrametaria and Coprinopsis cinerea fruiting bodies 



\section{CHAPTER 1}

General Introduction 



\subsection{Introduction}

Wood is a versatile material, being useful since standing in the forest till in service. The Alpine folks say that wood gives them three heats, first when cutting, second when moving them down the mountain and the third when being burnt in fireplaces. Wood does not only provide warmness, but it also gives a good construction because of its toughness. The strength of wood is the result of the complex structures forming several layers in wood microfibrils of cellulose, hemicelluloses, and lignin (Eaton and Hale 1993). Even though wood components provide the mechanic stability, they are also susceptible to degradation because of their compositions. The physical and biological factors can cause degradation as for example light, moisture, microorganisms, insects and marine borers (Eaton and Hale 1993), consequently wood properties are altered. Therefore, in order to maintain wood for longer use or to reduce deterioration, many researches have been carried out about woodmodification. For example, wood has been subjected to chemical modification e.g. with acetic anhydride, to impregnation with resins, to thermal modification and to plasma treatments (Hill 2006).

Except for damage by insects, practically almost all deterioration of wood is caused by decay fungi, which are therefore an important issue for wood industry. Although decay fungi cause considerable economic losses, they are also key factors as the major organisms decomposing forest biomasses. Therefore, they have very important ecological roles (Zabel and Morrell 1992; Boddy 1991; Boddy and Watkinson 1995).

\subsection{Wood Testing}

There are several approaches to prevent the progress of wood degradation leading to loss in wood properties such as mechanical properties and appearance. One first action could be already taken in the forest, immediately after tree cutting, where a biocontrol agent is applied to wood to prevent the establishment of blue stain fungi, which are commonly infecting only the sapwood of trees (Benjamin et al. 2003). Once the wood logs arrived in the wood- 
processing industries, the incoming wood is chemically or thermally treated before storage. For example, a dilute aqueous solution of sodium bisulfite and a phenolic compound can be applied in order to prevent microbial growth (US Patent 4045554). When applying those treatments, large quantity of chemicals may be used in order to ensure that the full wood material was treated and all microorganisms were affected. This handling may require more chemicals than indeed needed, resulting in high processing cost and environmental impacts. For these reasons there is a strong request of innovative solutions, and research on new wood modification and wood preservation is conducted in several experimental stations and Universities. Testing the durability of the modification against microorganisms is a central process of this type of research. It may take about 3-4 weeks by traditional testing methods where incubation with target microorganisms is preformed (Eaton and Hale 1993).

There are therefore two main research objectives in wood decaying processes, the first involving preservation of wood by preventing microbial infections and the second to detect and to identify which microorganisms are responsible for wood degradation. To this second aspect there have been several researches aiming to investigate the fungal infestations on wood. Those are, for example, using Fourier-transformed infrared spectrometry (FTIR) in discriminating of beech wood infested with Trametes versicolor and Schizophyllum commune (Naumann et al. 2005), using MALDI-TOF-MS to differentiate closely related indoor wood decay fungi (Schmidt and Kallow 2005). Molecular methods have been also proposed for fungal decayed wood investigation, i.e. identification of fungal decaying oak using polymerase chain reaction (PCR) (Parfitt et al. 2003) and detection of wood decay fungi Postia placenta (Poria placenta) and Coniophora puteana by using terminal restriction fragment length polymorphism (T-RFLP) (Råberg et al. 2005).

\subsection{Volatile Organic Compounds}

Volatile organic compounds (VOCs) are chemical substances that have high enough vapour pressures under normal conditions to significantly vaporize and enter the atmosphere (Grossmannova et al. 2007). The volatility of a chemical depends on the size (molecular weight), polarity, and structure of the molecule and can be expressed as the 
vapour pressure. Thus molecules with a high molecular weight and a high polarity have a low vapour pressure. As an example, the highly volatile ethyl acetate has a vapour pressure of 76 Torr at room temperature, while on the other end of the vapour pressure scale a low volatile compound is nonacosane $(n \mathrm{C} 29)$ with a vapour pressure of $5.0 \times 10^{-10}$ Torr at room temperature (Schulz 2001). However, international agencies define VOCs as organic chemicals containing carbon atoms and having a vapour pressure larger than 10 or $13.3 \mathrm{~Pa}$ at $25^{\circ} \mathrm{C}$, equal to $7.5 \times 10^{-2}$ or $9.9 \times 10^{-2}$ Torr, according to the EU Solvents Directive (1999/13/EC) and the American Society for Testing and Materials (method D3960), respectively. A wide range of carbon-based molecules, such as aldehydes, acids, alcohols, ketones, esters, hydrocarbons and terpenoids are VOCs. Moreover, various oxygen-, nitrogen-, sulfur-, and halogen-containing molecules are also VOCs (Hunter et al. 2000). They are released from several sources as shown in some examples in Table 1-1.

VOCs can contribute to pleasant or nasty odours, e.g. odours from flowers and foods are favoured, while smells of paints or moulds are not favoured. Moreover, VOCs could cause sickness. Recently it was revealed that microorganism-infested buildings released compounds affecting human health, generally known as "sick building syndrome" (Jaakkola et al. 2007). On the other hand, VOCs can be used in promoting human health, as the use of natural volatile compounds in aromatherapy.

An increasing interest of studying VOCs is coming from chemoeclogical sciences, since several VOCs have been found to play important roles in nature as chemical signals among different organisms and ecosystems. As an example, the so-called "cry for help" phenomenon is perhaps the most remarkable one. In this case plants released specific volatile compounds (e.g. methyl salicylate) as an external signal for the recruitment of beneficial insects (Forouhar et al. 2005). Therefore, VOCs are an issue of major concern for many scientists worldwide, being active in different disciplines such as wood technology, food, flavour and fragrances, medical, pharmaceutical, forensic sciences, and particularly environmental sciences (Demeestere et al. 2007). 
Table 1-1 Examples of VOCs from different sources

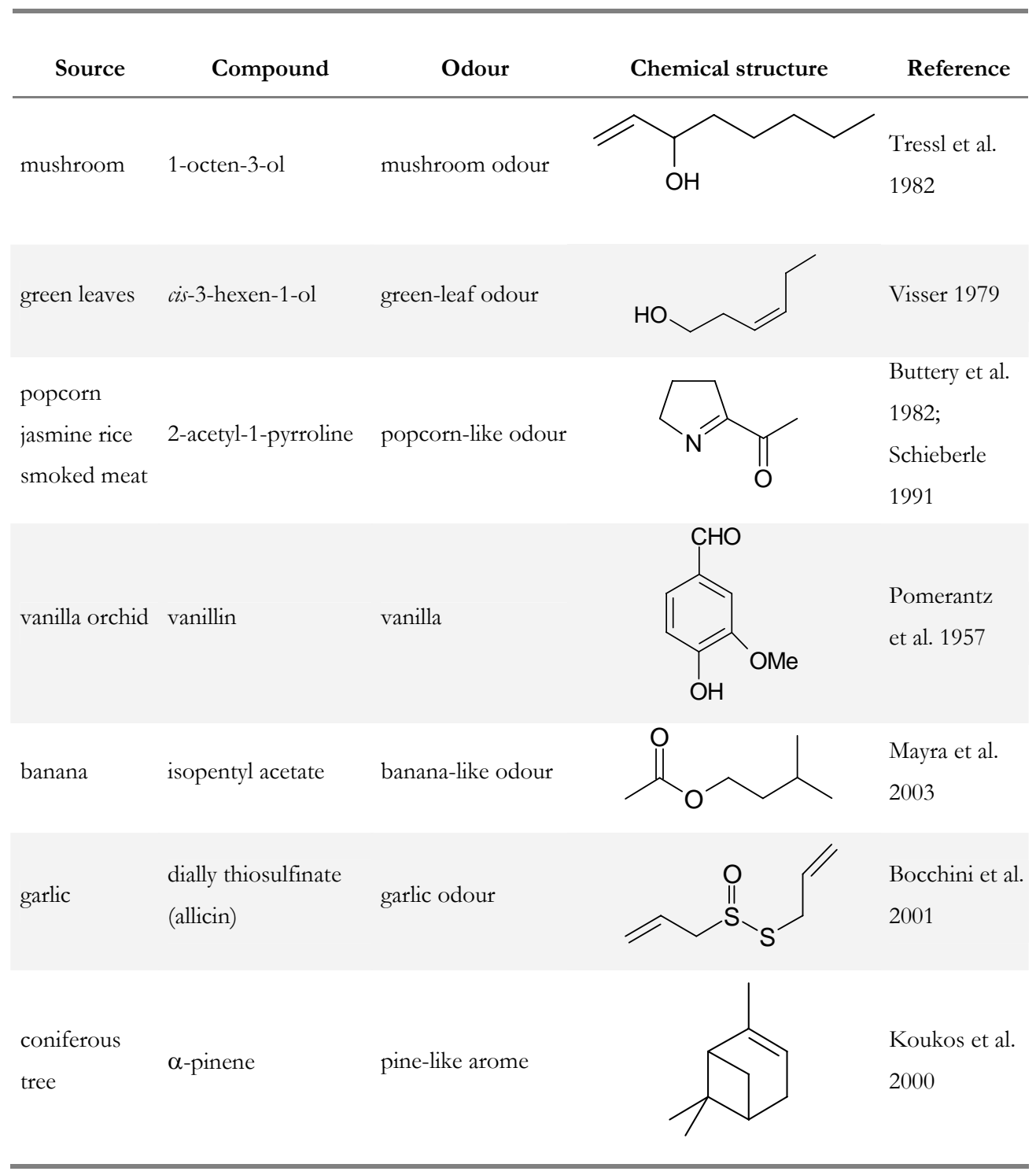

To increase the knowledge on the occurrence of VOCs in all fields of interest, precise and accurate analytical techniques are necessary. There are two main steps for volatile characterisation: volatile sampling and volatile analysis. 


\subsubsection{Volatile Sampling}

Appropriate volatile sampling and pre-concentration techniques are required particularly in environmental conditions where VOCs concentrations are often very low, varying mostly from levels of $\mathrm{pg} / \mathrm{l}$ to $\mu \mathrm{g} / \mathrm{l}$ in air. Sample preparation and sampling methods are often the bottleneck and most time consuming task in VOCs analytical scheme. They can be roughly categorised in: passive and active samplings as shown in Figure 1-1.

Passive sampling is performed without air circulation, i.e., static headspace sampling. The VOCs are sampled in static condition where they diffuse to specific absorbent materials. For example, solid phase microextraction (SPME) is a passive sampling technique where volatiles are adsorbed on polymer matrixes coated on silicon fibres (Zhang et al. 1994). In the last years, SPME has become an attractive and widely used sampling technique, despite its relative recent character (Belardi and Pawliszyn 1989; Arthur and Pawliszyn 1990). Another passive sampling technique is the direct headspace sampling, where the headspace volatiles are taken using a syringe and are accumulated in a cold trap, before being analysed. Passive sampling techniques are often adopted for indoor air measurements and when air samples are taken from a confined area. They are often chosen being less elaborated than active sampling techniques.

Active sampling is carried out by promoting an air circulation. The air is forced to pass through adsorbents where VOCs are trapped. Widely used absorbents are activated charcoal and polymer matrixex (i.e. TENAX ${ }^{\circledR}$, Gerstel, Mülheim an der Ruhr, Germany). The entrapped volatiles are later eluted with solvent for further analysis in case of chemical desorption (activated charcoal) or are eluted by hot gas and directly analysed in case of thermodesorption (TENAX). Active sampling requires power supply and may necessitate expensive equipments and skilled staff. Moreover, in this case there is a higher risk of contamination since pumps, loops and bags are often necessary. The advantages of active sampling are linked with a general higher sensitivity of the techniques and the possibility to quantify the volatile concentration and releasing rate with higher accuracy. Moreover, in case of solvent elution methods there is a possibility to store for long time the VOCs samples allowing further analyses. 


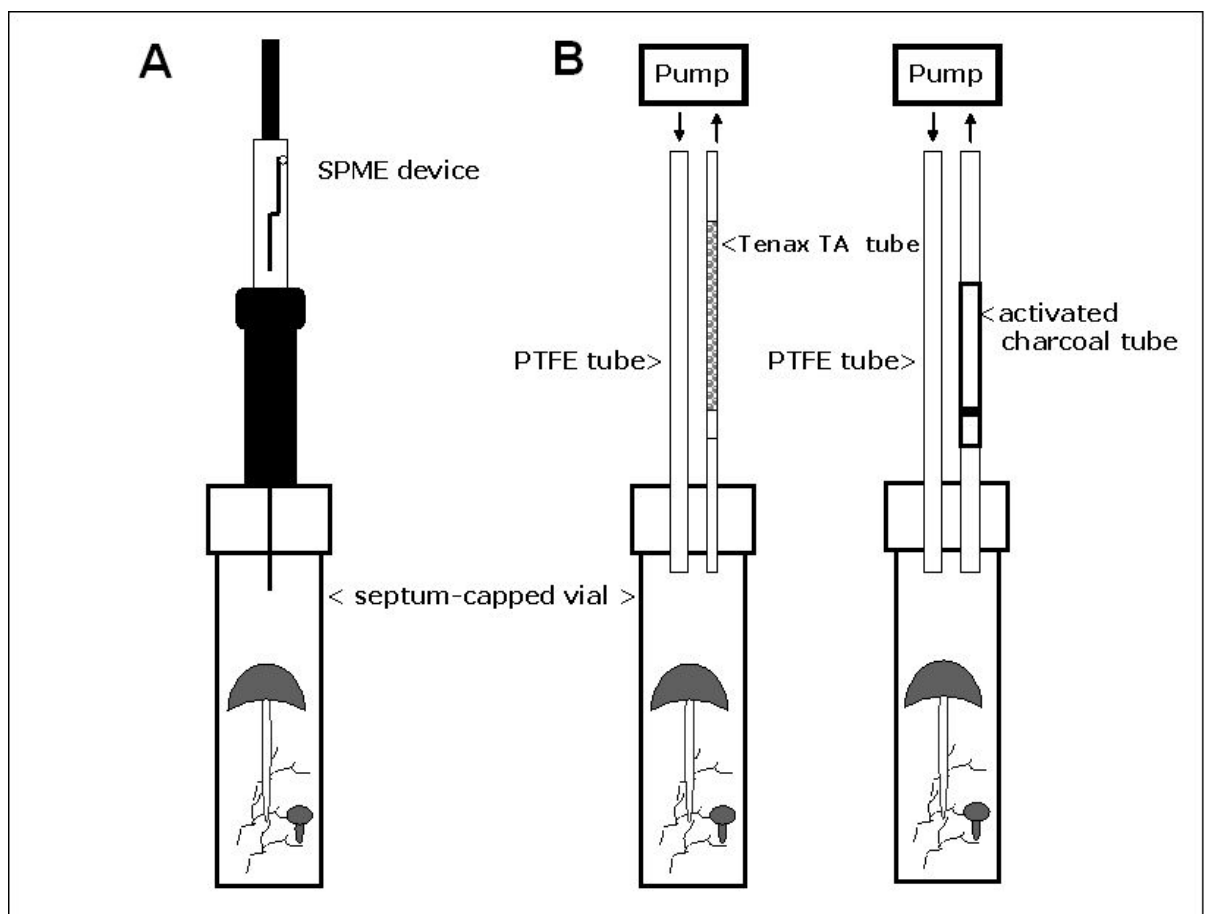

Figure 1-1 Schematic drawing of three volatile sampling methods. (A) passive sampling of static air with headspace-SPME device and (B) active sampling of circulating air with TENAX-TA tube (left) and activated charcoal tube (right).

\subsubsection{Volatile Analysis}

The analysis of volatile compounds is traditionally performed using gas chromatography (GC). There are many detectors which can be used in gas chromatography, each one giving different types of selectivity. Gas chromatography- flame ionisation detection (GCFID) uses ionised combustion products and is the most common detector. Gas chromatography-mass spectrometry (GC-MS) uses chemical masses of ionised fragments for interpretation. Gas chromatography- electroantennographic detection (GC-EAD) uses insect antennae as detectors as depicted in Figure 1-2. Volatiles dissolved in solvents are 
injected into the GC injection port and run through the GC column for separation. Volatiles absorbed in a polymer matrix have to be first desorbed, trapped and later heated up and run thought the GC column.

After the volatile samples are detected by the GC-MS, their chemical identification is done by interpreting and matching their mass spectra and retention times to the ones of authentic compounds. The Mass Spectral Search Library of the National Institute of Standards and Technology (NIST) and the Wiley GC-MS database are two mass spectra libraries widely adopted for this comparison.

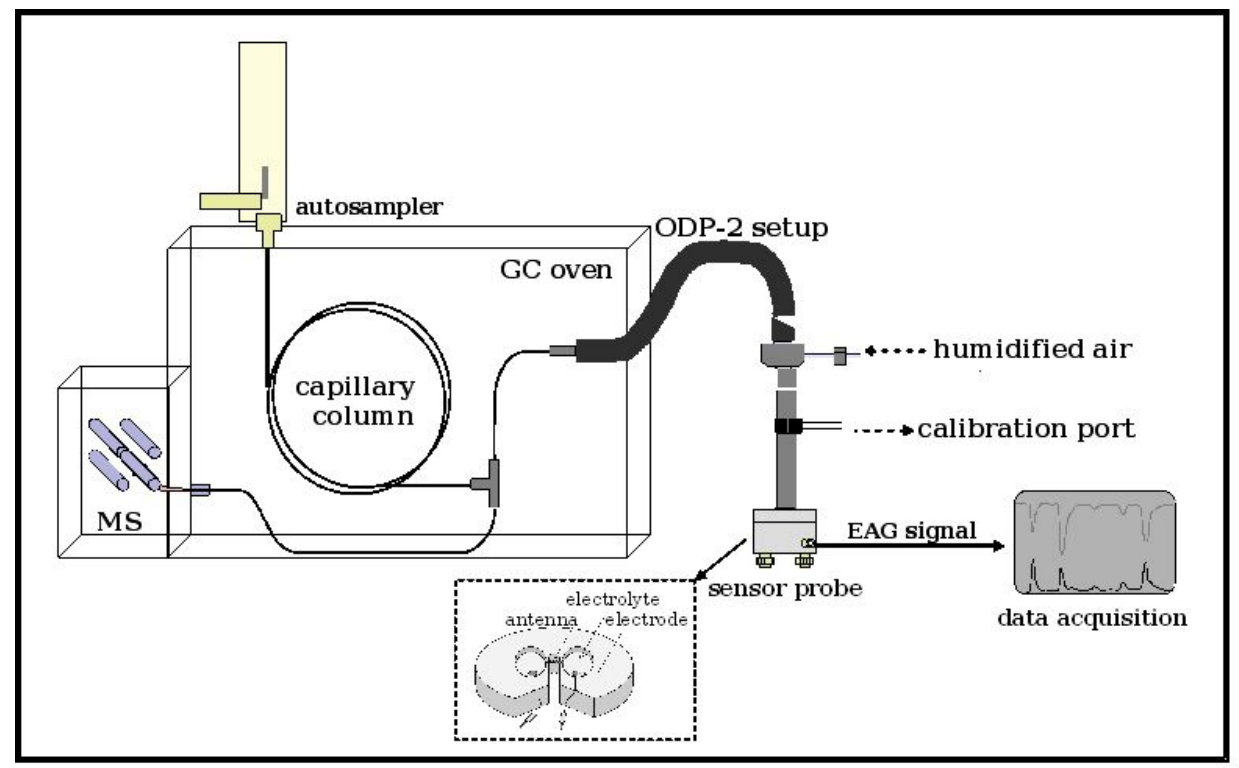

Figure 1-2 Schematic drawing of a gas chromatograph-mass spectrometer/electroantennographic detector setup (GC-MS/EAD). MS: mass spectrometer, GC: gas chromatograph, ODP: olfactory detection port and EAD: electroantennogram (modified from Weissbecker et al. 2004). 


\subsection{Insects and olfaction}

Insects belong to arguably the most successful and most diverse group of animals (Stork 2003). Out of 1.75 million species that have been formally described, 850,000 to $1,000,000$ are insect species. However, the number of undescribed species is undoubtedly much higher. Insects comprise over half of the described species, and circa $3 / 4$ of known animal species (Stork 2007). Whatever the global estimate, insects are highly diverse as illustrated in Figure 1-3. Not only insects are so abundant, but they have evolved to live on Earth for the last 400 million of years, with an extreme diversification and filling all available environmental niches (Grimaldi and Engel 2005). An outstanding feature is their sensory system. For instance, insect olfaction is highly evolved so that insects can search for food

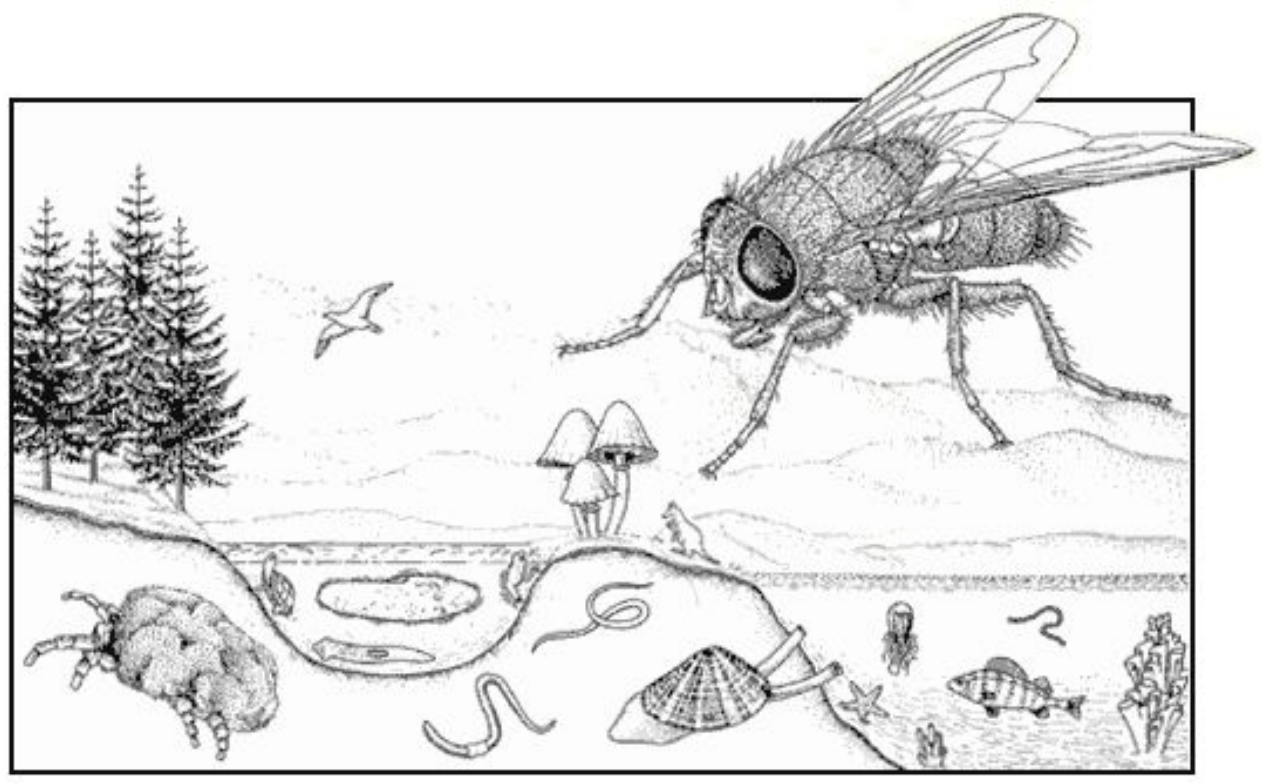

Figure 1-3 This "speciescape" illustrates the relative diversity of insects in relation to other species groups. The relative diversity is proportional to the size of the organism and therefore in the illustration above the fly is much larger than all the other organisms (after Wheeler 1990 and Gullan and Cranston 1999). 
sources, shelters and mates. In highly social species, like the honey bee and ants, olfaction is used to recognize a huge variety of airborne molecules, providing the members of the colonies with a high sensory network (Forêt and Maleszka 2006). In some cases the perception of VOCs is so highly sensitive to reach values far below modern analytical equipments. One interesting example is the black jewel beetle, Melanopbila acuminata (Coleoptera: Buprestidae) which can detect smoke odour as far as 50 kilometers to locate forest fires. Their larvae can develop only in burned wood (Schütz et al. 1999a). The most sensitive perception is evolved in the sex pheromone perception of male Lepidoptera. Minute quantities of the so-called sex pheromones can attract males from huge distances to the female insects for mating (Kassiling 1979).

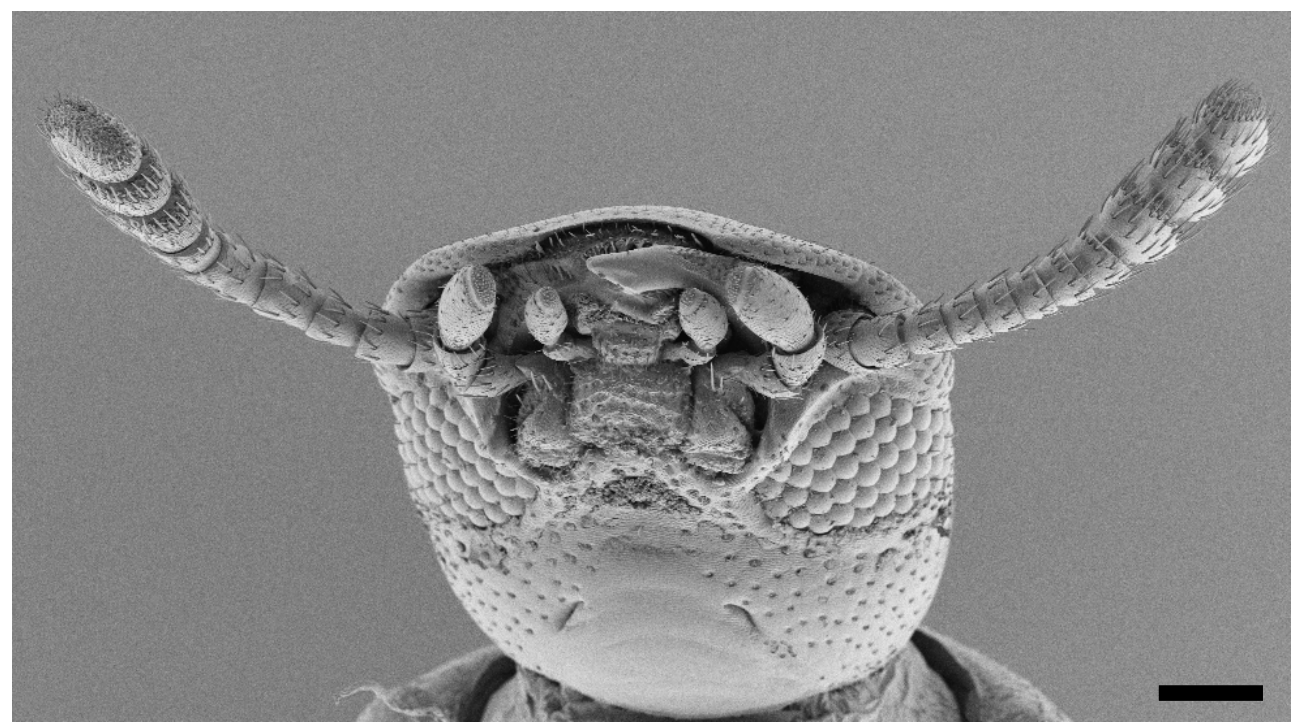

Figure 1-4 Scanning electron micrographs of the adult head of the rust red flour beetle Tribolium castaneum (Coleoptera: Tenebrionidae). General overview of the insect ventral part showing the antennae, the mouth parts and the compound eyes. Bar: $100 \mu \mathrm{m}$. (with courtesy of Dr. Sergio Angeli). 
Insect sensory organs are housed in hair-like structures, known as sensilla, which are protruding from the cuticle of specific organs as antennae, mouth parts, and tarsal segments, but also on other parts of the insect body as wings and external genitalia as shown in Figure 1-4 and in Figure 1-5. The insect sensilla (singular = sensillum) protrude from the cuticle, or sometime lie within or beneath it. They can be divided in chemo-, mechano-, thermo-, visual and hygrosensory sensilla (Keil 1999). The structures of all sensilla types are rather uniform regardless of the specific receptor modality.

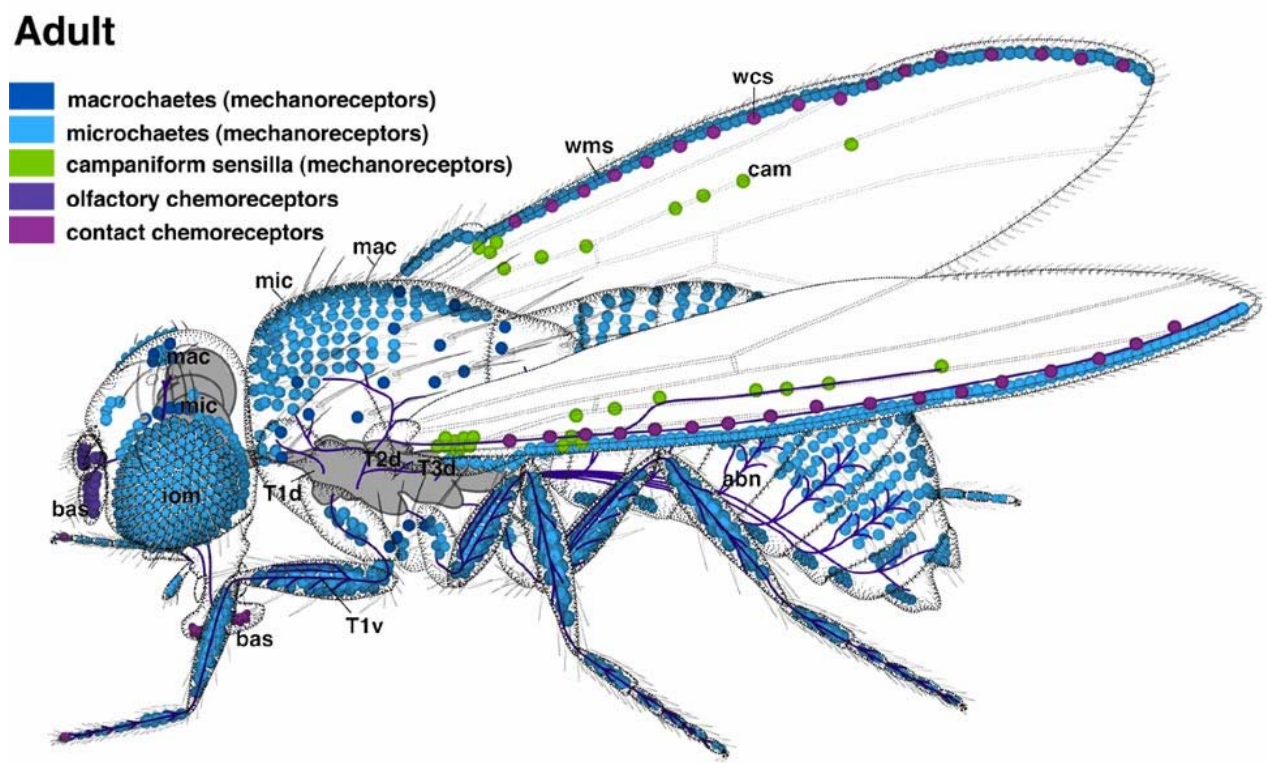

Figure 1-5 Schematic representation of the sensory organs and peripheral nerves of an adult fly. The main structural and functional subclasses of sensilla are represented in different colours. abn: abdominal nerves; bas: basiconic sensilla; cam: large campaniform sensilla of the wing blade; cns: central nervous system; iom: interommatidial bristles; mac: macrochaetae; mic: microchaetae; wcs: chemoreceptors of wing margin; wms: mechanoreceptors of wing margin (after Hartenstein 1993). 
Each sensillum consists of one or more bipolar receptor cells which send their axons to the brain and their dendrites to the peripheral cuticle region of stimulus uptake. A specific cuticular apparatus is present in the outside part of the sensillum and it exhibits features characteristic of the specific stimulus modality of the sensillum. Three types of auxiliary cells, thecogen, trichogen, and tormogen cells, surround the sensory neurones and border the sensillar lymph cavity (Figure 1-6). The sensillar cuticle plays an important role in stimulus transport to the receptor membrane of the sensory neurones. These neurones are surrounded by an extracellular fluid, the sensillar lymph, which composition is regulated by the auxiliary cells.

The chemosensory sensilla are divided in olfactory and gustatory sensilla. In insects the distinction between olfaction and taste is not as clear as in vertebrate, since olfactory sensilla can respond to substances in solution and gustatory sensilla can detect molecule in the vapour phase. However, the signal processing is however quite different for the two types of stimuli. The axons from all the olfactory neurones terminate in the antennal lobes, whereas the axons from gustatory sensilla terminate in the ganglion of the body segment to which the sensillum belongs, as for instance the suboesophageal ganglion for the sensilla of the maxillary palps. Insect olfaction is therefore defined as the neuronal transduction of all chemical compounds, which leads to the activation of antennal lobes, in analogy with the vertebrate where olfactory neurones terminate in the olfactory bulb (Schmuker and Schneider 2007).

Olfactory sensilla are more concentrated on the antenna and maxillary palps. Their cuticle structure shows the presence of numerous small wall pores, for this reason they are also called wall pore sensilla or multiporous sensilla.

The external morphology of these sensilla can be further distinct in sensilla trichodea, sensilla basiconica, and sensilla coeloconica. Sensilla trichodea have usually the external shape of hairs with a sharply pointed tip. They are usually the most abundant on the antennae. Sensilla basiconica have generally a smooth surface and are covered with irregular dense wall pores detected in large number over the external cuticle. In some species of Lepidoptera it was found that long sensilla trichoidea respond to the female pheromone, while sensilla 
basiconica are tuned to the perception of plant odour also called green volatiles or general odours or (Steinbrecht et al. 1996; Tegoni et al. 2004) (Figure 1-6, sensillar type d).

Gustatory sensilla are also called contact chemoreceptors. Most of them are found on the month parts as labrum, maxillae and labium, but they also occur on the antenna, tarsi and even on the female ovipositor. In contrast to the olfactory sensilla, they lack wall pores but have a single, terminal pore, therefore they are also called uniporus or terminal pore sensilla. (Figure 1-6, sensillar type c).

The olfactory transduction of odorant stimuli is performed on the cell membrane of the sensory neurones. Odorants are first absorbed on the cuticular surface of the sensillum and are thought to reach the interior part via the wall pores. The cavity of the pore is in some cases connected with pore tubules which some times directly contact the sensory neurone membrane. The conversion of extracellular chemical signal to a neurone electrical stimulus is known as signal transduction. In insects before odorants are coded into electrical signals they interact with the sensillar lymph, while in vertebrate they interact with the nasal mucosa. The group of biochemical processes which take place between the sensillar wall pores and the dendritic membrane of the sensory neurones are known as "perireceptor events" (Getchell et al. 1984). As a consequence, perireceptor events occur in the sensillar lymph which is an aqueous barrier, whereas odorants are often hydrophobic.

In the sensillar lymph odorants interact with different classes of soluble proteins: odorant binding proteins (OBPs) (Vogt and Riddiford 1981), chemosensory proteins (CSPs) (Angeli et al. 1999) and odorant degrading enzymes (ODE) (Vogt and Riddiford, 1981). OBPs are present in very high concentration in the sensillar lymph and, similar to the CSPs, they reversibly bind chemical stimuli. Binding capacity was demonstrated with sex pheromones and general odorants for some members of insect OBP (Pelosi 1994, 1998; Steinbrecht 1998) and for one member of CSPs (Ban et al. 2003). OBPs and CSPs are soluble proteins with a low pI (4-5) and low molecular weight (10-14 kDa). Whether these proteins participate in odour coding or function as carrier to transport the odorants 
to the olfactory receptors of the sensory neurones it is still not clear although several hypotheses have been proposed (Pelosi 2005; Forêt and Maleszka 2006).

Figure 1-6 Schematic representation of insect sensilla (above). A: the cellular organisation; B and $\mathrm{H}$ : mechanosensory campaniform sensillum; $\mathrm{C}$ and G: gustatory or terminal pore sensillum; $\mathrm{D}$, $\mathrm{E}$ and $\mathrm{F}$ : olfactory sensillum with single- (E) or double wall (F). ax: axon of the receptor cell; cu: cuticle: de: dendrite ep: epidermal cell (yellow); ne: receptor neurone (red); th: thecogen cell (green); to: tormogen cell (light brown); tr: trichogen cell (dark brown); sl: sensillar lymph (blue). Schematic representation of the insect olfactory transduction (under). (after Steinbrecht 1992).

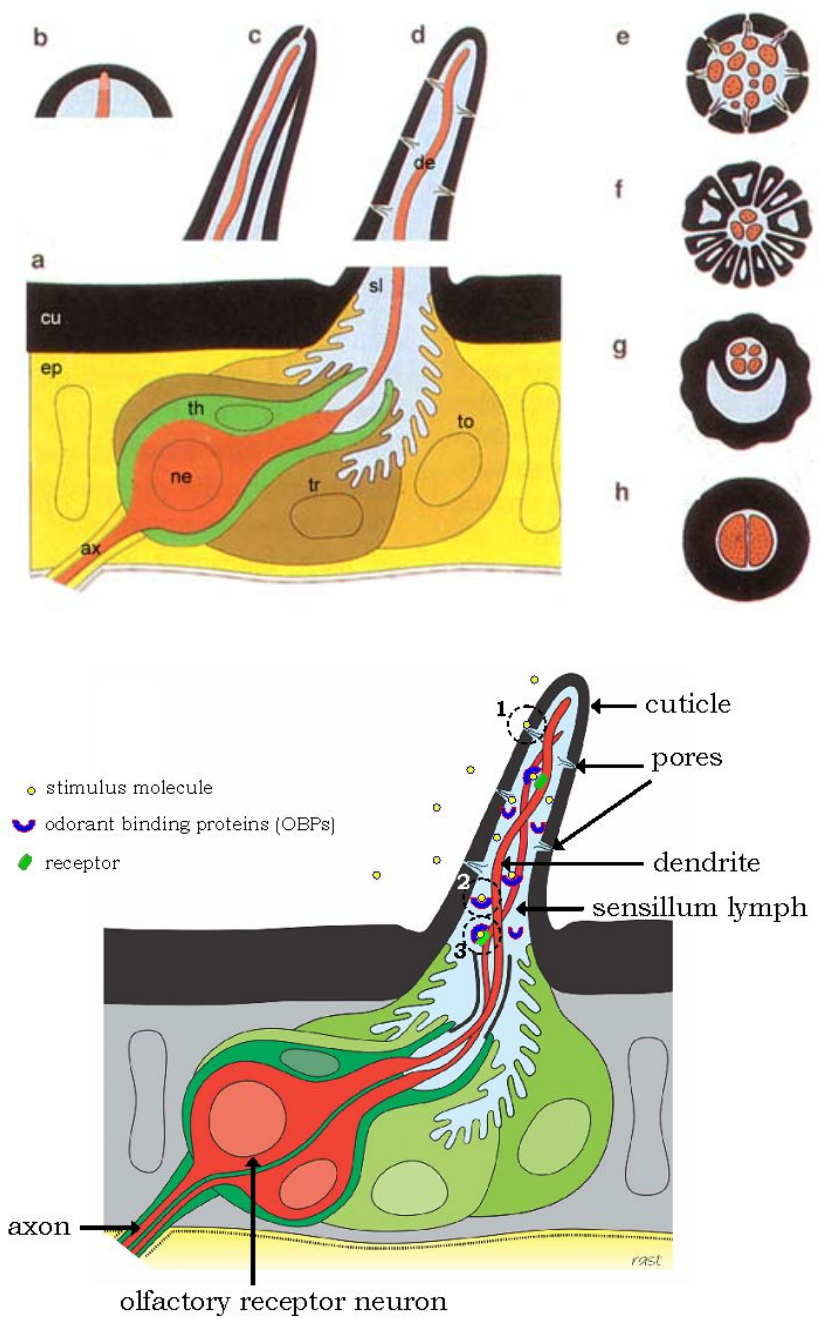


Odorant receptors are a group of transmembrane proteins, belonging to the class of G-protein coupled receptors. Once the odorant receptors are activated they drive two alternative intracellular signalling pathways, one utilising cAMP and the other inositol triphosphate $\left(\mathrm{IP}_{3}\right)$ as second messengers (Raming et al. 1993). These second messengers travel across the cell cytoplasm and activate gated ion channels, allowing $\mathrm{Ca}^{++}$(or other cations) to flow inside the cell. The increase in intracellular $\mathrm{Ca}^{++}$concentration appears to activate chloride a chloride current that helps to depolarise the olfactory cell leading to the generation of an electrical signal or action potential (Krieger et al. 1997).

\subsection{Electroantennography (EAG)}

Electroantennography is a technique to measure the electrical activity generated by an antenna for a given odorant. It is commonly used to study the function of the olfactory system in insects. The technique was developed after the discovery by the German biologist Dietrich Schneider (1957), who measured voltage changed between the tip and base of a freshly excised antenna from a male of the silkmoth, Bombyx mori, while the antenna was stimulated with an air puff containing the silkmoth sex pheromone bombykol. Schneider named this odour-prompted electrical response of an insect antenna an "electroantennogram" (EAG). It is interesting to note that his idea started thanks to a meeting with Schneider's neighbour (P. Karlson), who provided Schneider bombykol, the first discovered pheromone of animals (Butenandt et al. 1959) as nicely described later by Schneider (1999).

The EAG response is a bulk measure of the responses of the electrical depolarisations of many olfactory receptor neurones cells when the insect antenna is exposed to adequate stimulus (Figure 1-7). EAG responses are therefore related to the total number of stimulated sensilla (Mayer et al. 1984), although only in the recent years an explicit relationship to the neuronal activities has been demonstrated. The numbers of spikes elicited from receptor cells and the change in the EAG potential are interdependent measures of the stimulus strength (Mayer 2001). 

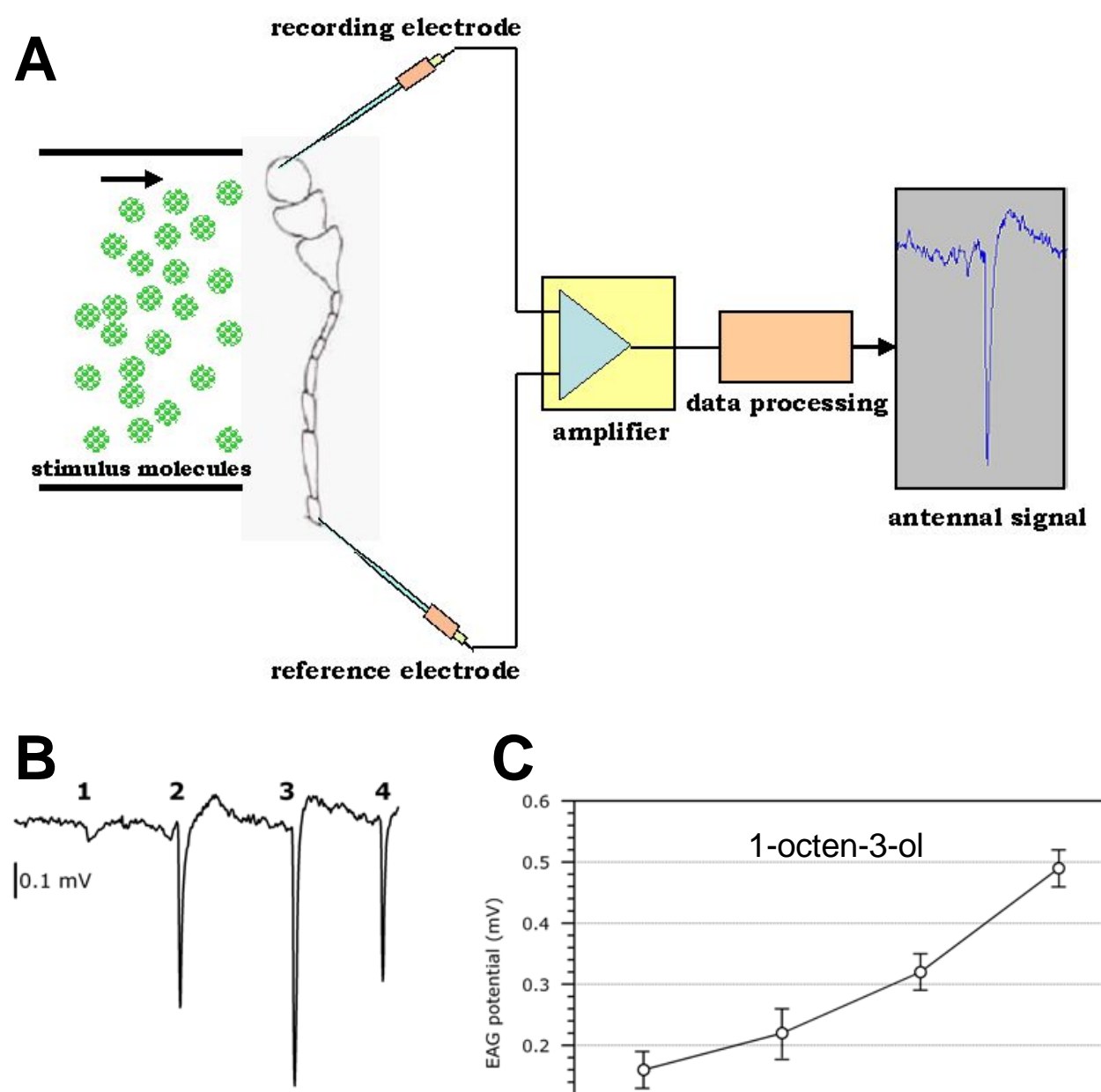

\footnotetext{
(1) control (filter paper + paraffinoil)

(2) 3-octanone

(3) 1-octen-3-ol

(4) octanal
}

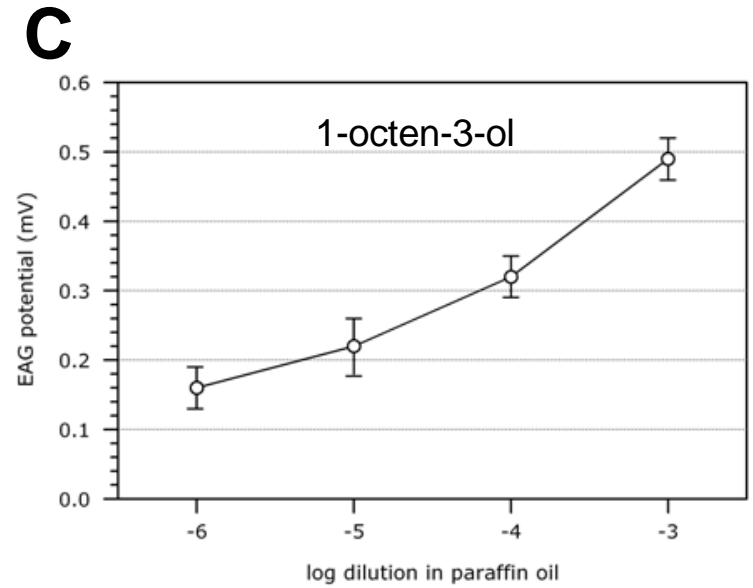

Figure 1-7 Electroantennography. (A) The antenna is exposed to stimulus molecules and the voltage changed between recording and reference electrodes is registered, after the signal is amplified and processed. (B) A typical antennal responses of the female beetle Cis boleti to different compounds at $10^{-3}$ paraffin dilution, and $(\mathrm{C})$ dose response curve of $C$. boleti to different dilutions (form $10^{-6}$ to $10^{-3}$ ) of 1-octen-3-ol. 
EAG registrations can be done in two ways: by exciting the antenna from the insect and make it in contact with two electrodes or by inserting a ground wire in an immobilised insect and another wire to the tip of its antenna (Figure 1-7). The latter method has the advantage that the insect antenna remains alive for longer time, therefore EAG signals can last very long. On the other hand, in this case the measurement is often disturbed by higher signal noise, due to the mechanical movement of the antenna and/or of the full animal.

The amplitude of the EAG responses is influenced many factors:

- nature and strength (concentration) of the stimulus;

- condition of the antenna e.g. sex, physiological status and previous stimulations;

- operating conditions e.g. temperature and humidity;

- quality of the amplifier input.

The insect circadian rhythm may also influence olfactory response, as it has demonstrated in the fruitfly, Drosophila melanogaster (Krishnan et al. 1999), and in the evolutionarily distant cockroach, Leucophaea maderae (Page and Koelling 2003). In the first case, EAG responses of flies tested near the middle of the night were significantly higher than those of flies tested at other times of the day. In the second case, a ten fold variation of the EAG amplitude was observed by testing odorants as specific time of the circadian rhythm. These experiments suggested that olfactory responses and circadian rhythm are linked with the photoreception and with the neuronal signalling of the insect optic lobes.

EAG technique has been further integrated with gas chromatography, by attaching an EAG detector to a gas chromatograph. This powerful analytical technique is known as a GC-EAD (gas chromatography-electroantennographic detection). With his apparatus it is possible to explore how insect antennae respond to different chemical compounds released by a given source as host plants or food substrates. To identify the volatile compounds detected by insects it is in this case necessary to run the samples separate in GC-EAD and GC-MS. This problem has been recently solved by the integration of the two systems. In this 
case the volatiles samples are injected in a gas chromatograph - mass spectrometer/electroantennographic detection (GC-MS/EAD), where the volatile substances are spitted between a mass spectrometer and a EAD detector at the end of the GC column (Figure 1-2) (Weissbecker et al. 2004). This system proved to be highly sensitive to compounds of importance to insects (able to detect them in the sub-picogram range) and profitably assists in chemical ecology research.

\subsection{Biosensors}

A biosensor is defined by the International Union of Pure and Applied Chemistry (IUPAC) as a "device that uses specific biochemical reactions mediated by isolated enzymes, immunosystems, tissues, organelles or whole cells to detect chemical compounds usually by electrical, thermal or optical signals" (Rasooly 2005). A biosensor consists of two main parts: a biological component also called biocomponent and a signaltransducing component. The biocomponent is a living organism or a biological product. The schematic of biosensor with some accessories is depicted in Figure 1-8.

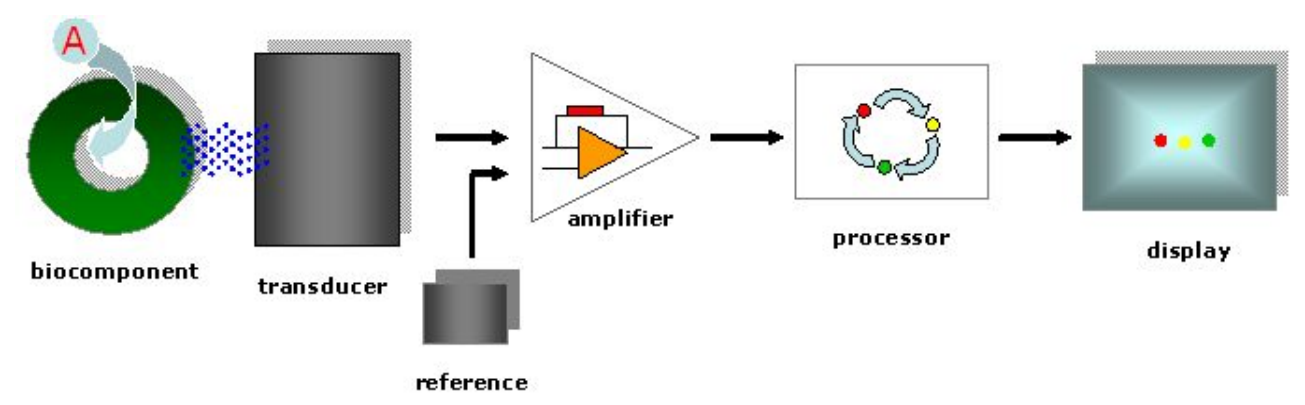

Figure 1-8 Schematic representation of a biosensor. A biosensor consists of two main parts: a biological component also called biocomponent (leftmost), which is sensitive to a target chemical compound (A) and a signal-transducing component. The latter is here represented by a transducer, an amplifier, a processor and a display. The biosensor may be equipped with a calibration part, here represented by a reference. 
Biosensor devices have great prospects in commercial applications in such fields as biomedicine, environmental monitoring, pharmacology, agriculture, quality control of food and water, and military applications. Biosensors are now being developed for detection of microbial pathogens and their toxins, monitoring and analysing blood metabolites, cancer monitoring and detection, allergen detection, food and biomaterial quality testing, and basic research on molecular interactions.

The most widespread example of a commercial biosensor is perhaps the blood glucose biosensor, which measure the concentration of blood glucose by using an enzyme to break down glucose. In doing so there is a transfer of electrons to an electrode, allowing a measurement of blood glucose concentration (Fogh-Andersen and D'Orazio 1998). Other examples are the use of yeast and filamentous fungi as sensing elements for detecting cell activities (Boranian 2004), the use of anaerobic bacteria as biosensors for analysing degradable organic matter in waste water (Kumlanghan et al. 2007), and the use of specific enzymes in amperometric biosensors for food analysis (Prodromidis and Karayannis 2002). Moreover, biosensors are developed in military applications as to detect buried explosives by using bacteria as sensing organisms (US Patent 5972638).

An ideal biosensor offer several advantages over other analytical methods including rapid and even real-time measurements, high sensitivity, selectivity, and stability (a rule known as "the three-S-rule") even when a complex or turbid sample matrix is used.

Olfactory-based biosensors have been fabricated by combining olfactory biocomponents with various signal-transducing devices. Olfactory biocomponents are for instance: intact insects, insect antennae, olfactory receptor neurons, and olfactory receptor proteins. These biocomponents are combined with detecting devices such as quartz crystal microbalance (QCM), field effect transistor (FET), microelectrode, surface plasmon resonance (SPR) and light addressable potentiometric sensor (LAPS) (Wu et al. 2007).

In this thesis we refer to the term "antennosensor" as an olfactory-based biosensor where the biocomponent part is an insect antenna, as the name hints. Insect antennae are highly sensitive to selective volatile compounds, wherefore they are ideal biocomponents of an olfactory-based biosensor. The study of insect olfaction started since the discovery 
of the first sex pheromone of the silkmoth, Bombyx mori (Lepidoptera: Bombycidae) as previously described (Schneider and Hecker 1956). A review about these aspects has been written by Keil (1999). Male moth antennae are extremely sensitive to their female sex pheromones. For example, amounts of less than $10 \mathrm{pg}$ of bombykol offered in a piece of filter paper elicit a typical behavioural response in the males (Kassiling 1979). Another extreme case was found in a jewel beetle Melanophila acuminata (Coleoptera: Buprestidae) which could detect guaiacol derivatives produced from forest fire in a range of part per billion (ppb) and in a distance as far as 50 kilometres (Schütz et al. 1999a).

The advantage of high volatile recognition allow insect antenna to be exploited as a biocomponent in a biosensor, providing fast and non-destructive detections. There are several applications by using insect antennae as detectors, especially in agriculture. For example, the antennae of Colorado potato beetle Leptinotarsa decemlineata (Coleoptera: Chrysomelidae) were used for identifying fungal-infested potatoes (Schütz et al. 1999b). By detecting the odorant 2-ethyl-hexane-1-ol, one single infested potato could be found up to $100 \mathrm{~kg}$ of healthy potatoes (Schütz et al. 1999b).

In other cases the antennae of Pectinophora gossypiella (Lepidoptera: Gelechiidae) and Cydia pomonella (Lepidoptera: Tortricidae) were used as biocomponents of portable biosensors to detect the ambient distribution of species specific pheromones in cotton fields (Färbert et al. 1997; Koch et al. 2002) and apple orchards (Koch et al. 1997), respectively. These applications are of high values in biocontrol of pest insects, where pheromone dispensers are adopted of mating disruption approach (Angeli et al. 2007). 

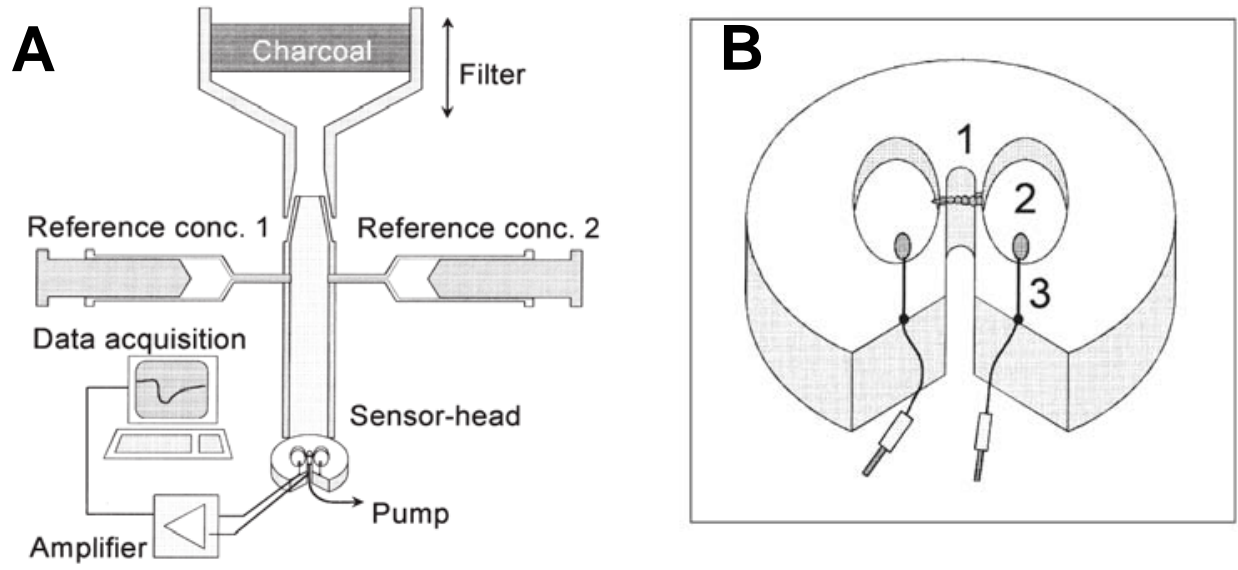

C
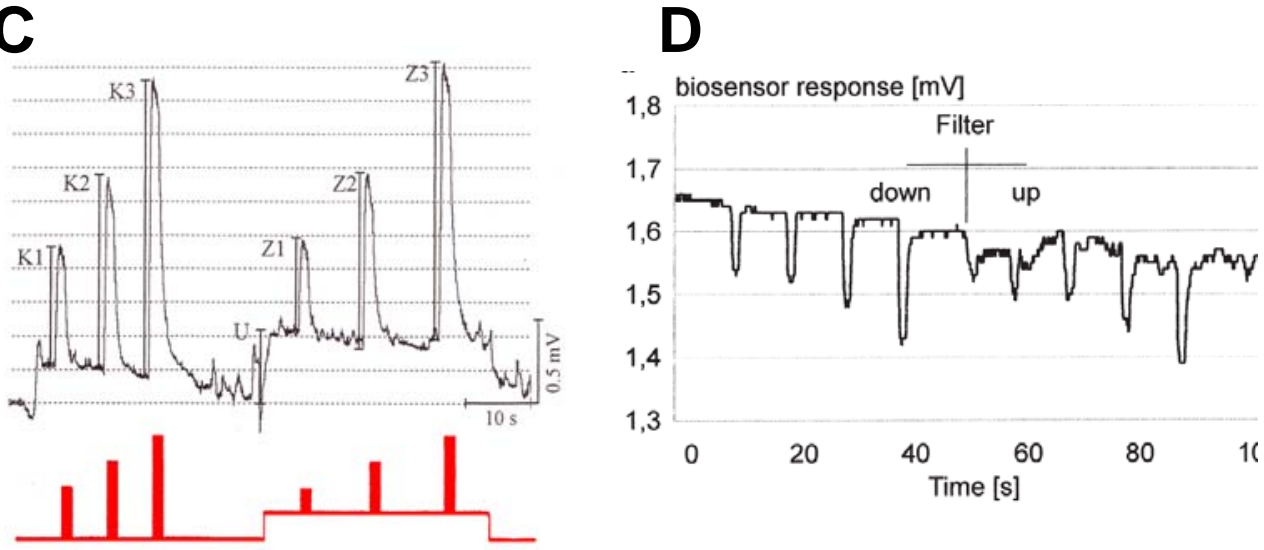

Figure 1-9 Schematic drawing of the biosensor-system. (A) Sampling and calibration system. (B) Antenna holder. 1: antenna, 2: reservoir of electrolyte, 3: $\mathrm{Ag} / \mathrm{AgCl}$-electrode. (C) Recording of 1 measurement cycle using superposition technique in a lepidopteran species. Upper trace: EAG recording. Lower trace: recording of syringe and filter activity. Vertical bars indicate syringe concentration of the puffs. K1, K2, K3: EAG amplitude generated by increasing odorant concentration when filter air was in the background. Z1, Z2, Z3: EAG amplitude generated by increasing odorant concentration when ambient air was the background. (D) Recording of 1 measurement cycle using superposition technique in a coleopteran species. First 4 EAG amplitudes (from left) generated when filter air was in the background. Second 4 EAG amplitudes (right) generated when ambient air was in the background. Draw A, B and D after Schütz et al. 1999b; draw C after Färbert et al. 1997. 
Olfactory-based biosensors can be grouped in two categories: qualitative biosensors, which provide information only in respect to the presence or not of the target compounds, and quantitative biosensors, which allow quantifying the concentration of the target compounds. A biosensor of the first type has been developed by van der Pers and co-workers (van der Pers and Minks 1998).

In case of quantitative biosensors have to hold a calibration part. In other words, the electrical signal, detected from the biocomponent and recorded in the transducing component, has to provide information about the concentration of the chemical stimulant. To achieve this goal it is important to isolate the background detection, which affects the target compound detection, and to calibrate the system.

In the antenna-based biosensor utilised in the present thesis, these parameters were controlled as described fully by Färbert et al. (1997). Since this is a critical part of the antenna-base biosensor a briefly description is here provided. The background effect was controlled by exposing the antenna first to a filtered and clean air and subsequently to the ambient air, where a target compound had to be measured. Antennal responses were measured by air puffs from three syringes previously equipped with defined concentrations of the target compound.

The concentration of the target compound in the ambient air was achieved by measuring first the antennal responses to define concentrations of the target compound when the antenna was exposed to filtered air, and then similar measurements were repeated when the antenna was exposed to the ambient air. The first three antennal responses were therefore not influenced by the ambient air, while the last three antennal responses are measured as extra signals, meanwhile the antenna was affected by the odorants of the ambient air. Generally, in the last three antennal responses there is a decrease of the peak amplitude as shown in the Figure 1-9. The comparison between the antennal responses registered without and with ambient air allowed the calculation of the concentration of the target compound by adopting defined algorithms. Basically, this operating way is called "superposition technique" and the biosensor is reported to operate in a "superposition mode" (Schütz et al. 1999b). More details about the adopted 
algorithms and the exact operating conditions are provided in the original publication (Färbert et al. 1997), in the pioneer works (Koch 1990; Milli et al. 1996) and in the following applications (Schütz et al. 1999b; Schütz et al. 2001; Koch et al. 2002).

Recently, olfactory-based biosensors are also proposed as new way to monitor and quantify volatile organic compounds that arise from food and beverages. In this content, an on going project aims to develop a so-called "Cybernose" as a robust, sensitive and portable biosensor to detect odorants of interest to the food and beverage industries (Trowell 2008). The biocomponent of this biosensor will be based on cluster of odorant receptors from a variety of species, including the fruitfly, Drosophila melanogaster, the nematode worm Caenorbabditis elegans and the silkmoth Bombyx mori. By 2013, the authors aim to develop a biosensor that will enable the wine industry to precisely measure aroma and flavour compounds.

Moreover, olfactory biosensors are an additional system for further studying the basic processes occurring in olfactory transduction.

In conclusion, "biosensors now play a vital and essential role in medicine, industry and the environment, providing routine analysis, crucial monitoring, and early detection of problems and crisis points. Biosensors are increasingly finding applications in homeland security, as well as in bio/pharmaceutical research. The market for biosensors is forecast to swell to $f_{5} .7$ billion in 2007 , with an annual growth rate of around $10 \%$ ", as reported by Adikan et al. (2006).

\section{7. Purposes of this research}

The experimental work of this $\mathrm{PhD}$ thesis was focused on pioneer studies for the development of "a biosensor system for wood degradation using volatile organic compounds". To achieve this result the following investigations were carried out:

1. Characterisation of VOCs released from fungal-infested wood (Chapter 3)

2. Characterisation of VOCs released during fruiting body development by using the fungus Coprinopsis cinerea as a model organism (Chapter 4) 
3. Olfactory detection of fungal VOCs by the fungivorous beetle Cis boleti (Chapter 5 and 6 )

4. Olfactory detection of VOCs released from C. cinerea by the associated fly Suillia mikii (Chapter 7)

5. Assessment of the Cis boleti antennae as the biocomponent in a biosensor system for the detection of wood decay (Chapter 8).

\subsection{References}

Adikan FRM, Webb AS, Standish RJ, Sahu JK, Holmes C, Major HE, Kundys D, Gates JC, Gawith CBE, Smith PGR, Payne DN. 2006. Sense and fibrelity: next generation optical biosensors. Optoelectronics Research Centre, University of Southampton, UK, Publication N.

Angeli G, Anfora G, Baldessari M, Germinara GS, Rama F, De Cristofaro A, Ioriatti C. 2007. Mating distuption of codling moth Cydia pomonella with high densities of Ecodian sex pheromone dispensers. Journal of Applied Entomology 131: 311-318.

Angeli S, Ceron F, Scaloni A, Monti M, Monteforti G, Minnocci A, Petacchi R, Pelosi P. 1999. Purification, structural characterization, cloning and immunocytochemical localization of chemoreception proteins from Schistocerca gregaria. European Journal of Biochemistry 262: 745-754.

Arthur CL, Pawliszyn J. 1990. Solid phase microextraction with thermal desorption using fused silica optical fibers, Analytical Chemistry 62: 2145-2148.

Ban LP, Scaloni A, Brandazza A, Angeli S, Zhang L, Yan YH, Pelosi P. 2003. Chemosensory proteins of Locusta migratoria. Insect Molecular Biology 12: 125-134.

Belardi RP, Pawliszyn J. 1989. The application of chemically modified fused silica fibres in the extraction of organics from water matrix samples and their rapid transfer to capillary columns. Water Pollution Research Journal of Canada 24: 179-191.

Benjamin WH, Thawaites JM, Farrell RL, Blanchette RA. 2003. Albino strains of Ophiostoma species for biological control of sapstain fungi. Holzforschung 57: 237-242.

Bocchini P, Andalòa C, Pozzia R, Gallettia GC, Antonelli A. 2001. Determination of diallyl thiosulfinate (allicin) in garlic (Allium sativum L.) by high-performance liquid chromatography with a post-column photochemical reactor. Analytica Chimica Acta 441: 37-43.

Boddy L, Watkinson SC. 1995. Wood decomposition, higher fungi, and their role in nutrient redistribution. Canadian journal of botany 73 (Suppl.): S1377-S1383.

Boddy L. 1991. Importance of wood decay fungi in forest ecosystems. In: Arora DK, Rai B, Mujerii KG, Knudsen GR, (Eds). Handbook of applied mycology. Soils and plants. Vol. 1. Marcel Dekker Inc., New York. pp. 507-540.

Boranian KHR. 2004. The use of yeast and mounds as sensing elements in biosensors. Biosensors and bioelectronics 19: 953-962. 
Butenandt A. Beckmann R, Stamm D, Hecker E. 1959. Über den Sexuallockstoff des Seidenspinners Bombyx mori. Reindarstellung und Konstitution. Zeitschrift für Naturforschung 14b: 283-284.

Buttery RG, Ling LC, Juliano BO. 1982. 2-Acetyl-1-pyrroline: An important aroma component of cooked rice. Chemistry and Industry, London. 24: 958-959.

Demeestere K, Dewulf J, De Witte B, van Langenhove H. 2007. Sample preparation for the analysis of volatile organic compounds in air and water matrices. Journal of Chromatography A 1153: 130-144.

Eaton RA, Hale MDC. 1993. Wood: decay, pests and protection. Chapman and Hall, London, UK.

Färbert P, Koch UT, Färbert A, Staten RT, Cardé RT. 1997. Pheromone concentration measured with EAG in cotton fields treated for mating disruption of Pectinophora gossypiella (Lepidoptera: Gelechiidae). Environmental Entomology 26: 1105-1116.

Fogh-Andersen N. D'Orazio P. 1998. Proposal for standardizing direct-reading biosensors for blood glucose. Clinical Chemistry 44: 655-659.

Forêt S, Maleszka R. 2006. Function and evolution of a gene family encoding odorant bindinglike proteins in a social insect, the honey bee (Apis mellifera). Genome Research 16: 14041413.

Forouhar F, Yang Y, Kumar D, Chen Y, Fridman E, Park S, Chiang Y, Acton T, Montelione G, Pichersky E, Klessig DF, Tong L. 2005. Structural and biochemical studies identify tobacco SABP2 as a methyl salicylate esterase and implicate it in plant innate immunity. Proceedings of the National Academy of Sciences 102: 1773-1778.

Getchell TV, Margolis FL, Getchell ML. 1984. Perireceptor and receptor events in vertebrate olfaction. Progress in Neurobiology 23: 317-345

Grimaldi D, Engel MS. 2005. Evolution of the insects. Cambridge University Press, Cambridge, New York.

Grossmannova H, Ciganek M, Krcma F. 2007. High-molecular products analysis of VOC destruction in atmospheric pressure discharge. Journal of Physics: Conference Series 63: Article n. 012011

Gullan PJ, Cranston PS. 1999. The insects: an outline of entomology. Stanley Thornes (Publishers) Ltd., United Kingdom.

Hartenstein V. 1993. Atlas of Drosophila Development. Cold Spring Harbor Laboratory Press, Cold Spring Harbor, New York.

Hill C. 2006. Wood modification: chemical, thermal and other processes. Wiley, West Sussex, England.

Hunter P, Oyama ST. 2000. Control of volatile organic compound emissions: conventional and emerging technologies. JohnWiley \& Sons, Inc., New York, 2000.

Jaakkola MS, Yang L, Ieromnimon A, Jaakkola JJK. 2007 Office work exposures and respiratory and sick building syndrome symptoms. Occupational and Environmental Medicine 64: 178-184.

Kaissling KE. 1979. Recognition of pheromones by moths, especially in Saturniids and Bombyx mori. In: Ritter FJ. (Ed) Chemical ecology: Odour communications in animals. Elsevier/ North-Holland/Biomed Press, Amsterdam. pp. 43-56.

Kaissling KE. 1987. Insect olfaction. Typographisher Betrieb W. Biering, H. Numberger, Munich, Germany.

Koch UT, Cardé AM, Cardé RT. 2002. Calibration of an EAG system to measure airborne concentration of pheromone formulated for mating disruption of the pink bollworm 
moth, Pectinophora gossypiella (Saunders Lep., Gelechiidae). Journal of Applied Entomology 126: 431-435.

Keil TA. 1999. Morphology and development of the peripheral olfactory organs. In: Hansson BS. (Ed). Insect olfaction. Springer-Verlag Berlin Heidelberg, Germany. pp. 1-47.

Krishnan B. Dryer S. Hardin P. 1999. Circadian rhythms in olfactory responses of Drosophila melanogaster. Nature 400: 375-378.

Krieger J, Maneli M, Breer H. 1997. Elements of the olfactory signalling pathways in insect antennae. Intertebrate Neuroscience 3: 137-144.

Koch UT. 1990. A portable EAG system for measurement of pheromones in the field. In: Proceedings of the 200th National Meeting of the American Chemical Society, Division of Agricultural and Food Chemistry. (Washington D.C. August 26-31, 1990) Abstract 31.

Koch UT, Lüder W, Clemens S, Cichon LI. 1997. Pheromone measurements by field EAG in apple orchards. Technology Transfer in Mating Disruption, IOBC wprs Bulletin 20: 181190.

Koukos PK, Papadopoulou KI, Patiaka DTh, Papagiannopoulos AD. 2000. Chemical Composition of Essential Oils from Needles and Twigs of Balkan Pine (Pinus pence Grisebach) Grown in Northern Greece. Journal of Agricultural and Food Chemistry. 48: 1266-1268.

Kumlanghan A, Liu J, Thavarungkul P, Kanatharana P, Mattiasson B. 2007. Microbial fuel cellbased biosensor for fast analysis of biodegradable organic matter. Biosensors \& Bioelectronics 22: 2939-2944.

Mayer MS, Mankin RW, Lemire GF. 1984. Quantitation of the insect electroantennogram: measurement of sensillar contributions, elimination of background potentials, and relationship to olfactory sensation. Journal of Insect Physiology 30: 757-763.

Mayer M. 2001. Nomographic correspondence between specialist cell responses, electroantennograms and the probability of behavioral response: the importance of comparable stimuli and a benchmark. Journal of Insect Physiology 47: 19-29.

Mayra D, Märka T, Lindingera W, Brevard H, Yeretzian C. 2003. Breath-by-breath analysis of banana aroma by proton transfer reaction mass spectrometry. International Journal of Mass Spectrometry 223-224: 743-756.

Milli R, Koch UT, de Kramer JJ. 1996. Measurement of pheromone distribution in apple orchards treated for mating disruption of Cydia pomonella. Entomologia Experimentalis et Applicata 82: 289-297.

Nauman A, Navarro-González M, Peddireddi S, Kües U, Polle A. 2005. Fourier transform infrared microscopy and imaging: Detection of fungi in wood. Fungal genetics and biology 42: 829-835.

Page TL, Koelling E. 2003. Circadian rhythm in olfactory response in the antennae controlled by the optic lobe in the cockroach. Journal of Insect Physiology 49: 697-707.

Parfitt D, Hynes J, Rogers JH, Boddy L. 2003. New PCR assay detects rare tooth fungi in wood where traditional approaches fail. Mycological research 109: 1187-1194.

Pelosi P. 1994. Odorant-binding proteins. Critical Reviews in Biochemistry and Molecular Biology 29: 199-228.

Pelosi P. 1998. Odorant-binding proteins: structural aspects. Annals of the New York Academy of Sciences 855: 281-293.

Pelosi P, Calvello M, Ban L. 2005. Diversity of odorant-binding proteins and chemosensory proteins in insects. Chemical Senses 30S: 291-292 
Pomerantz R, Goldblith SA, Proctor BE. 1957. Vanilla Evaluation, Rapid Spectrophotometric Technique for Evaluation of Vanilla Extracts. Journal of Agricultural and Food Chemistry 5: 292-293.

Prodomidis MI, Karayannis MI. 2002. Enzyme based amperometric biosensors for food analysis. Electroanalysis 14: 241-261.

Råberg U, Höberg NOS, Land CJ. 2005. Detection and species discrimination using rDNA TRFLP for identification of wood decay fungi. Holzforschung 59: 696-702.

Raming K, Krieger J, Strotmann J, Boekhoff I, Kubick S, Baumstark C, Breer H. 1993. Cloning and expression of odorant receptors. Nature 361:353-356

Rasooly A. 2005. Biosensor technologies. Methods 37: 1-3.

Schieberle P. 1991. Primary odorant in popcorn. Journal of Agricultural and Food Chemistry 39: 1411-1144.

Schmidt O, Kallow W. 2005. Differentiation of indoor wood decay fungi with MALDI-TOF mass spectrometry. Holzforschung 59: 374-377.

Schmuker M, Schneider G. 2007. Processing and classification of chemical data inspired by insect olfaction. Proceedings of the National Academy of Science 104: 20285-20289

Schneider D, Hecker E. 1956. Zur Elektrophysiologie der Antenne des Seidenspinners Bombyx mori bei Reizung mit angereicherten Extrakten des Sexuallockstoffes. Zeitschrift Naturforschung 11b: 121-124.

Schneider D. 1957. Elektrophysiologische Untersuchungen von Chemo- und Mechanorezeptoren der Antenne des Seidenspinners Bombyx mori. Zeitschrift für vergleiche Zoologie 40: 8-41.

Schneider D. 1999. Insect pheromone research: some history and 45 years of personal recollections. In: International Organisation for Biological Controll of Noxioux Animals and Plants. West Palaearctic Regional Section Bulletin 22: 1-10.

Schulz S. 2001. Selectivity in chemical communication systems of arthropods. In: Barth FG, Schmid A (Eds). Sensory Ecology. Springer, Stuttgart. pp. 237-252.

Schütz S, Weissbecker B, Hummel HE, Apel K-H, Schmitz H, Bleckmann H. 1999a. Insect antennae as a smoke detector. Nature 398: 298-299.

Schütz S, Weißbecker B, Koch UT, Hummel HE 1999b. Detection of volatiles released by diseased potato tubers using a biosensor on the basis of intact insect antennae. Biosensors and Bioelectronics 14: 221-228.

Schütz S, Weißbecker B, Schroth P, Schöning MJ. 2001. Linkage of inanimate structures to biological systems - Smart materials in biological micro- and nanosystems. In: Hoffmann, K.H. (Ed) Lecture notes in computational science and engineering. Springer-Verlag, Heidelberg - New York. pp. 215-221.

Steinbrecht RA. 1992. Cryotechniques with sensory organs. Microscopy and Analysis 20: 9-11.

Steinbrecht RA. 1996. Structure and function of insect olfactory sensilla. In: Bock GR, Cardew G. (Eds). Olfaction in mosquito-host interactions. Wiley, Chichester, UK. pp. 158-177.

Steinbrecht RA. 1998. Odorant-binding proteins: expression and function. Annals of the New York Academy of Sciences 855: 323-332.

Stork NE. 2003. Biodiversity. In: Resh VH, Cardé RT (Eds). Encyclopedia of Insects. Academic Press, San Diego. pp. 85-91.

Stork NE. 2007. Biodiversity: world of insects. Nature 448: 657-658.

Tegoni M, Campanacci V, Cambillau C. 2004. Structural aspects of sexual attraction and chemical communication in insects. Trends in Biochemical Sciences 29: 257-264. 
Tressl R, Bahri, D, Engel KH. 1982. Formation of eight-carbon and ten-carbon component in mushroom (Agaricus campestris). Journal of Agricultural and Food Chemistry 30: 89-93.

Trowell S. "The Flagship Cybernose project" for quality biosensors for the Food Futures National Research Flagship of the Australian National University. http://www.csiro.au/partnerships/ps241.html (verified 20/01/08).

van der Pers JNC, Minks AK. 1998. A portable electroantennogram sensor for routine measurements of pheromone concentrations in greenhouses. Entomologia Experimentalis et Applicata 87: 209-215.

Visser JH. 1979. Electroantennogram responses of the Colorado beetle Leptinotarsa decemlineata to plant volatiles. Entomologia Experimentalis et Applicata 25: 86-97.

Vogt RG, Riddiford LM. 1981. Pheromone binding and inactivation by moth antennae. Nature 293: 161-163.

Weissbecker B, Holighaus G, Schütz S. 2004. Gas chromatography with mass spectrometric and elecroantennographic detection: analysis of wood odorants by direct coupling of insect olfaction and mass spectrometry. Journal of Chromatography A 1056: 209-216.

Wheeler QD. 1990. Insect diversity and cladistic constraints. Annals of the Entomological Society of America 83: 1031-1047.

Wu CS, Wang LJ, Zhou J, Zhao LH, Wang P. 2007. The progress of olfactory transduction and biomimetic olfactory-based biosensors. Chinese Science Bulletin 52: 1886-1896.

Zabel RA, Morrell JJ. 1992. Wood Microbiology: decay and its prevention. Academic Press, Inc. New York.

Zhang Z, Yang MJ, Pawliszyn J. 1994. Solid phase microextraction. Analytical chemistry 66: 844A-853A. 



\section{CHAPTER 2}

\section{Volatile Compounds for Wood Assessment}

\section{Prodpran Thakeow, Gerrit Holighaus, and Stefan Schütz}

Thakeow P, Holighaus G, Schütz S. 2007. Volatile compounds for wood assessment. In: Kües U, editor. Wood production, wood technology and biotechnological impacts. Universitätsverlag Göttingen, Göttingen. pp. 197-228.

Contributions to this chapter: I contributed to the parts related to fungal volatiles and fungi-insect interaction. 



\subsection{Introduction}

Utilisation of volatile organic compounds (VOCs) for the quality assessment of wood is basically a bionic concept which is inspired by the impressive achievements of insects in performing this task just by olfaction in order to exploit wood as a resource. The word "bionics" is made up of the two words "biology" and "electronics". In German, however, the second part comes from "Technik", which means engineering in this context. In English, this approach of combining biology and engineering is often also called "biomimetics". The two expressions are used more or less synonymously. The interdisciplinary field of bionics is about scrutinising and transferring "natural inventions" into technical applications. In the course of evolution, nature has developed, improved and tested these inventions over millions of years. For technical exploitation, the optimised solutions to a specific set of problems have firstly to be thoroughly analysed. Subsequently, the newly described solutions can be implemented in technical applications with corresponding boundary conditions.

In order to highlight possibilities and limits of an assessment of wood by detecting VOCs released by wood, the first part of this contribution deals with the genesis of VOCs in wood, in fungi and in wood infested by fungi. In the second part, the interaction with insects is used as example how nature exploits the content of information encoded in patterns of VOCs released by wood. By examination of the recognition processes of insects and a parallel trace analysis of related VOC patterns released by fungus infested wood, we might learn how to assess wood quality as well as the kind and state of fungal infestation by detecting wood-released VOCs in a quick and non-destructive manner. In view of that, current techniques are displayed enabling the detection of specific VOCs or of patterns of VOCs released by wood, in order to suggest possible lines of development for devices assessing wood quality. 


\subsection{Volatiles released by living trees}

In the discussion of greenhouse gases and their impact on global climate changes (Hüttermann and Metzger 2007; Majcherczyk and Hüttermann 2007), there is an increasing interest in the complex chemistry of the troposphere. The dynamics of the global atmospheric chemistry through climate forcing is triggered by VOCs (Holopainen 2004; Dindorf et al. 2005). Beside VOCs of anthropogenic origin, especially VOCs emissions from forests which are covering ca. 30\% of landmass (FAO 2006) are sources affecting the system. The quantities of volatiles of natural origin (NVOC) released above the main landmasses as arable land and forests exceed by far the quantities from anthropogenic sources. Due to their dominance, reactivity and physical properties, they are classified as VVOCs (very volatile organic compounds like methane), reactive VOCs (isoprene and terpenes) and non-reactive VOCs (Guenther et al. 1995).

VOC-emissions by plants are unavoidable due to their metabolic activities (Peñuelas and Llusià 2004). A dominant reactive VOC released by forests for example is isoprene, which is widespread but not generally present throughout the plant kingdom (Harley et al. 1999, Owen and Peñuelas 2005). Isoprene is discussed to play an important role in tropospheric chemistry (Fehsenfeld et al. 1992; Lerdau et al. 1997). Similar to terpenes, its reactivity influences the atmospheric dynamics of ozone, formation and deposition of organic nitrates and organic acids (Harley et al. 1999). Due to this importance in atmospheric processes, algorithms were developed describing the dependence of isoprene and terpene emissions of plants on light and temperature (Dindorf et al. 2005). Further factors as drought, diurnal and seasonal variation or growth conditions were discussed as parameters influencing the VOC emissions of plants (Dudt and Shure 1994; Staudt et al. 2001, 2003). However, there are undisputable many additional internal (e.g. genetic, biochemical) and external (e.g. interaction with fungi and insects) factors that affect the presence (Litvak and Monson 1998) and emission of different VOCs by trees and other plants (Apel et al. 1999; Peñuelas and Llusià 2001; Schütz et al. 2004) which are not yet covered by known algorithms. 
Most trees are grouped, due to their affinity, in coniferous and broadleaved species. This is also reflected in their VOCs composition: VOCs differ highly from coniferous to broadleaved woodlands. Regarding coniferous trees, VOC-research is almost exclusively done in the family of Pinaceae, e.g. Pinus, Picea, Larix, Abies, Tsuga, and Cedrus (Hayward et al. 2004; Lee et al. 2005). Broadleaved species were examined on a somewhat broader scale comprising Fagales (Betula, Fagus, Quercus), Sapindales (Acer, Castanea) and e.g. Salicaceae (Salix, Populus) (Pasteels and Rowellrahier 1992; Tollsten and Müller 1996; Hakola et al. 2001; Paczkovska et al. 2006). Further genera such as Eucalyptus (Guenther et al. 1993; Zini et al. 2002) are characterised and several comparative studies screened plant species for single VOCs only (Owen et al. 1997). Plant VOCs are mostly alkanes/alkenes, aromatic hydrocarbons, alcohols, phenolics, terpenes, esters, aldehydes and ketones (Kesselmeier and Staudt 1999). However, due to technical restrictions, the analytical window covers currently only compounds with boiling points between $60^{\circ} \mathrm{C}$ to $250^{\circ} \mathrm{C}$ at atmospheric pressure, and of intermediate to high thermal stability (Schütz 2001).

General processes in plant cells, as the lipoxygenase (LOX)-pathway (Feussner and Wasternack 2002) are responsible for the release of generalistic VOCs as the so called “green leave volatiles" (GLV). Mainly alcohols, aldehydes of linear six carbon chains and their derivatives such as $(Z)$-3-hexen-1-ol, $(Z)$-3-hexen-1-yl-acetate, hexan-1-ol, and (E)-2-hexenal belong to this group (Visser 1979). Whereas the name GLV implies the paradigm that only leaves (not needles) are releasing these compounds, it was proven that coniferous trees release these compounds, too, but only in minute amounts (Schütz et al. 2004). GLV are released in low rates from nearly every plant species (Hatanaka 1993) and show a typical increase on mechanical wounding (de Bruxelles and Roberts 2001; Mithöfer et al. 2005) of any type of plant tissue, be it leaves, needles, stems or roots (Matsui 2006). Especially young developing leaves and damaged leaves - and leaves are damaged by wind or insects in a forest all the time - release increased rates of GLV. With regard to the function of trace compounds with low emission rates as carrier of information ("infochemicals"), these minor components must however not be neglected (Schütz 2001; Schütz et al. 2004). GLV are known to play an important role in insect attraction and aggregation (Visser 1979; Schütz et al. 1997, 2004; Ruther 2000) or insect repellence 
(Huber and Borden 2001; Zhang and Schlyter 2004) and even in signalling between plant individuals, known as the phenomenon of "talking trees" (Tscharntke et al. 2001; Arimura et al. 2002, Engelberth et al. 2004; Farag et al. 2005). All this points out a complex interactive defence system in plants in which the VOCs play the role of a language. VOCs carry information about the constitutive or induced defence status of the plant, whether it is mechanically wounded, attacked by insects or micro-organisms (Schütz et al. 1997; Schütz 2001; Holopainen 2004: Weissbecker et al. 2004; Holighaus and Schütz 2006; Johne et al. 2006a, b; Paczkovska et al. 2006).

Isoprenoids are characteristic defence chemicals of conifers and are produced through the mevalonate (MEV) or methyl-erythritol-diphosphate (MEP) pathways (Keeling and Bohlmann 2006). They are highly variable in structure $(>30,000$ terpenes are known) and occur in trees as isoprene (C5), monoterpenes (C10), sesquiterpenes (C15) and diterpenes (C20) (Sharkey and Singsaas 1995; Phillips and Croteau 1999; Trapp and Croteau 2001). Following just the name of a compound, for instance, $\alpha$-pinene should not be mistaken in that it is exclusively released by coniferous trees like Pinus spp. For example, European beech (Fagus sylvatica, Fagaceae) seems to be a much stronger monoterpene emitter than expected. The monoterpenes of this species, studied by Dindorf et al. (2005) and Moukhtar et al. (2005), are dominated by sabinene with more than $90 \%$ of the daily terpene emission, but the typical coniferous volatiles $\alpha$-pinene and $\beta$-pinene were also found in the VOC pattern of beech trees. This holds also true for Quercus suber, the cork oak (Pio et al. 2005). $\alpha$-Pinene, sabinene, $\beta$-pinene and limonene were the main compounds $(80 \%)$ among the released terpene fraction from the oak.

Within taxonomic groups of lower plants, the VOC patterns are more alike, based on a more similar biochemistry of secondary plant compounds (Asakawa 2004). This relationship is treated in the scientific field of chemotaxonomy (Harborne and Turner 1984). However, variability of VOC patterns can be high, notwithstanding the degree of relationship. The Southern beech Nothofagus dombeyi releases $\alpha$-pinene in considerable amounts, whereas five other species of Nothofagus do not at all (Quiroz et al. 1999). A similar variability was shown by Harley et al. (1999) for isoprene emission of several woody and herbaceous plant species of Northern America. 


\subsection{Volatiles released by trunks and deadwood}

Trees provide a huge variety of plant tissues and plant surfaces. Compared to herbaceous plants, their surface is much bigger and more sculptured resulting in a higher variety of local VOC pattern and subsequent niches for interacting organisms. For example, $80 \%$ of VOCs stored in and released by needles of Pinus sp. and Picea sp. are identical with those released by the trunk of the trees, but they display significantly different quantitative patterns of VOCs (Sjödin et al. 2000; Schütz et al. 2004). In contrast to leaves and needles, there are only few systematic examinations about the influence of internal or external parameters on VOC patterns or released VOC quantities of wood or bark of trees (Schütz et al. 2004; Holighaus and Schütz 2006). However, various commercial interests lead to the analysis of chemical bark contents. Bark (root or trunk) as well as wood (root or trunk) are outstanding sources for commercial products since rich in essential oils (Wang et al. 2005) which are often VOCs. These defence chemicals against attacking organisms often display antibiotic activity and are used for various aspects in human life, e.g. in medicine (Kalemba and Kunicka 2003), food (Burt 2004) and personal care products (Priest 2002). Besides, VOCs are examined for applications in biotechnical plant protection and biotechnical stored product protection (Manker 2005).

At the beginning of the dieing process of a tree, a remarkable differentiation of the ecological system "tree" takes place resulting in a tremendous diversity of species of insects and micro-organisms (Harmon 1986; Moore et al. 2004). The exact point of initiation of the dieing process, whether caused by storm, insects, fungi or other circumstances, is often hard to define. Although felling or breaking down is often stated as the borderline between living tree and deadwood, when looking closely to physiological and chemical processes, a clear separation is hardly possible. Continuously during life, cells of healthy trees die and are rebuilt. Programmed cell death (PCD) is an integral part of plant development and also of defence. It occurs at all stages of the life cycle, from fertilisation of the ovule up to death of the whole plant. Indeed, without it, tall trees would probably not exist (van Doorn and Woltering 2005). Permanent stress of the environment like oxidative stress, heat or draught, infestation by micro-organisms, etc. causes the loss 
of protective compounds which have to be renewed (Sharkey and Singsaas 1995; Blokhina et al. 2003; Loreto et al. 2006 and citations therein). The oxidation of unsaturated fatty acids as constituents of lipid membranes or storage compounds of cells leads to the production of aliphatic aldehydes, alcohols, alkanes and other VOCs (Feussner and Wasternack 2002). These kinds of compounds can all the time be found produced in bark and wood (Weissbecker et al. 2004; Holighaus and Schütz 2006). Attacks of fungi and insects increase oxidative stress on the plant tissue and, in the course, the emission rates of these VOCs (de Bruxelles and Roberts 2001; Schütz 2001). Such biotic stress occurs very often in living plants and in many instances it can be overcome or healed. If the plant is however not able to cope with the related damage, the dieing process is initiated. Regardless of whether biologically initiated or caused by felling, the end of a tree does not result in "chemical silence" since not all the cells of a tree are at the time dead. The defence system and other cell functions are still working, until the storage pools are empty and dieing is completed. In case of such deadwood, the decay process of a tree and wooden substrate results in an extensive release of VOCs, changing considerably due to abiotic environmental factors (humidity, temperature etc.) and biotic interactions (fungi, micro-organisms and insects) (Paiva 2000). The complexity of decay is demonstrated by the VOCs released from bark of a F. sylvatica trunk subsequently to felling (Figure 2-1). Felled beech trunks release more than 140 volatile compounds in detectable amounts during the first phase of decay (0-2 years after felling), up to 70 of them simultaneously. Differences between small bark samples hint at a high spatial variability of chemical processes of decay and related volatiles within one trunk (Figure 2-1; Holighaus and Schütz 2006).

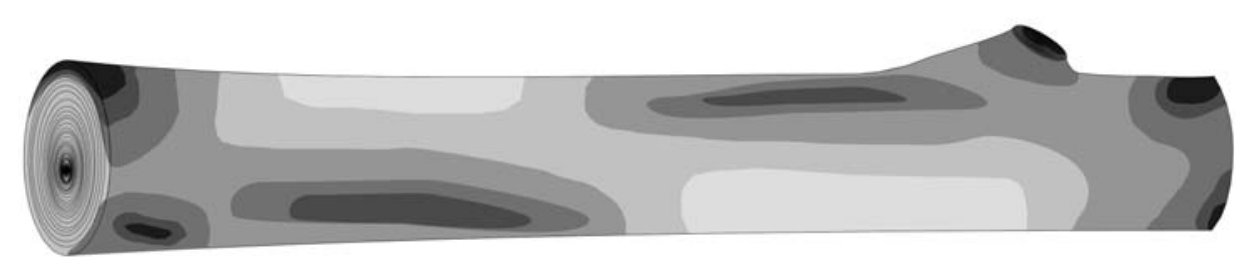

Figure 2-1 Distribution of physiological decay states on beech trunk; grey to black patches: fresh to seriously decayed (modified from Holighaus and Schütz 2006). 

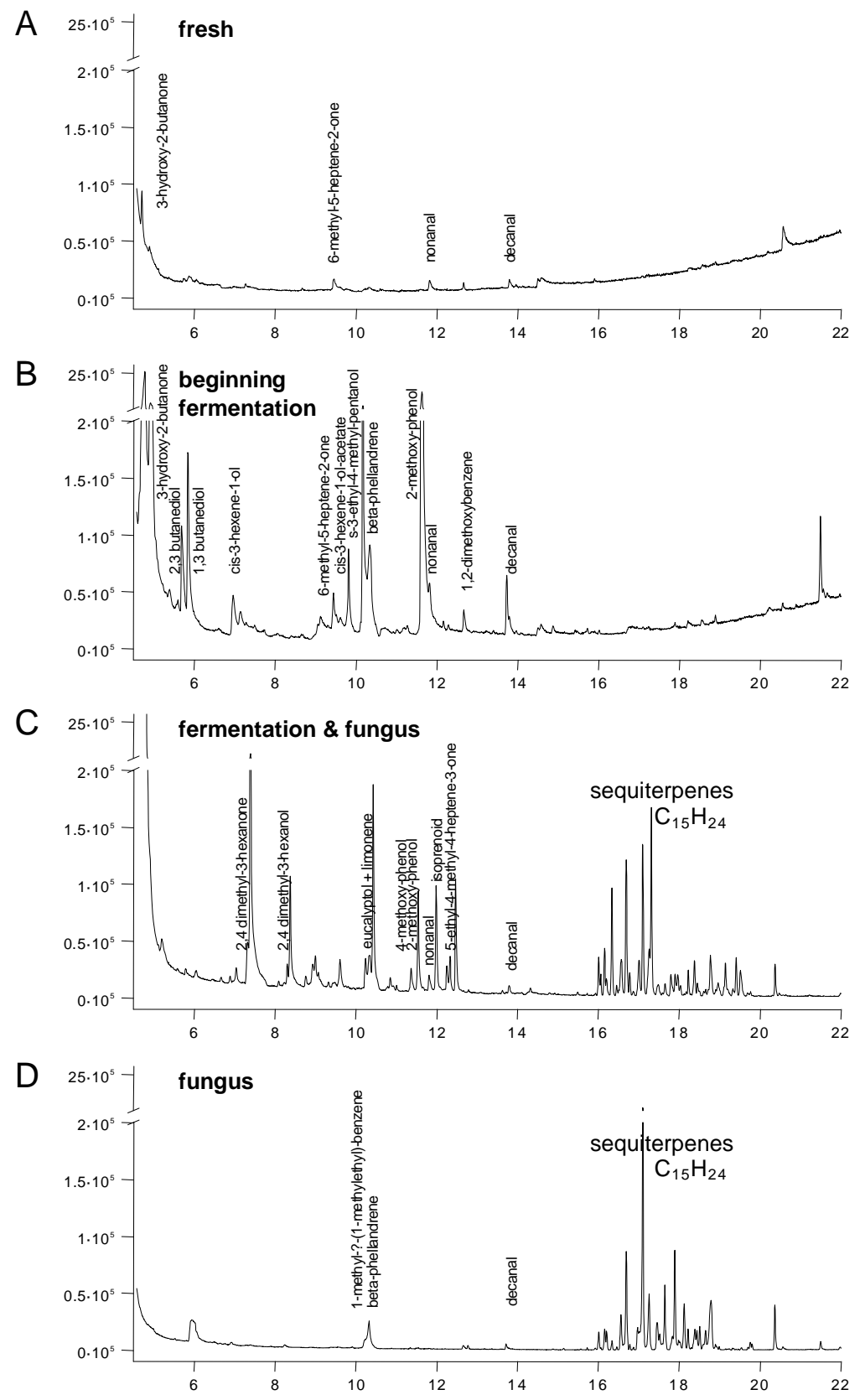

Figure 2-2 VOC patterns released by differently decayed bark patches on a trunk of European beech (data from Holighaus and Schütz 2006). 
Starting with felling, the number of volatiles and the emission rates of aldehydes increase (Holighaus and Schütz 2006). Following the decay progress, exemplary chromatograms yielding from a gas-chromatographic separation and subsequent massspectrometric detection of VOCs released by the bark of a beech trunk are displayed in Figure 2-2 with the main compounds named. Several simple and branched alcohols occur at the beginning of the fermentation process in the headspace of bark tissue (Figure 2-2B). Beside terpenes, phenolic compounds as 2-methoxy-phenole, 4-methoxy-phenole and 1,2dimethoxy-benzene emanate during the phase of oxidising bark tissue. They vanish fast and the branched alcohols change to longer straight-chained alcohols (Figure 2-2B, C). At initial infestation with white rot fungi, up to 30 sesquiterpenes are additionally detected in the bark samples (Figure 2-2C). After predominant degradation of lignin and cell structures of the bark by fungi, only sesquiterpenes are left to release (Figure 2-2D).

\subsection{VOCs emitted by wood and wood products}

Wood is one of the most widespread building materials. For usage in constructions, the fading of natural metabolic processes in wood is ennced by drying. The dried "deadwood" does not any more release VOCs on the basis of metabolic processes of the wood cells and, also, a part of the constitutive defence VOCs evaporated during the drying processes. VOC release rates differ between different drying and modification processes (Otwell et al. 2000). Air dried wood releases 8 times more VOCs than thermally modified wood (Manninen et al. 2002). The thermal modification has a high impact on wood chemistry and constructive properties. Thermally modified wood is dominated by aldehydes (hexanal), carboxylic acids and esters, air dried coniferous wood by terpenes (Tjeerdsma et al. 1998).

Analytical research on VOCs released by wood and wood products is performed by two reasons. Firstly, several VOCs released from wood are suspected to be toxic or cancerogenic to human beings. The main focus of examinations is therefore on toxic VOCs as well as on unpleasant odours (Bleich et al. 1998). Compared to solid wood, the 
release rate of VOCs of several derived timber products is significantly reduced (e.g. $\mathrm{OSB}=0.25 \mathrm{x}, \mathrm{MDF}=0.05 \mathrm{x}$ ), whereas the rate of aldehyde emission is much higher (Barry and Corneau 1999; Risholm-Sundman et al. 1998; Risholm-Sundman 2002). Of high concern are toxic formaldehyde emissions of processed wooden products (Sundin and Roffael 1992; Bleich et al. 1998; Schäfer and Roffael 2000; Kloeser et al. 2007; Müller et al. 2007). Glues and binding agents are releasers of this compound (Kloeser et al. 2007; Müller et al. 2007). According to Marutzky and Roffael (1977) and own examinations, freshly cut wood itself releases considerable amounts of formaldehyde surpassing sometimes even legal thresholds. However, the quantity of formaldehyde emissions of cut wood decreases quickly. Usually, after 6 month of storage, formaldehyde emissions of wood are below detection limits. Other natural compounds from wood discussed in the context of toxicity belong to the group of monoterpenes (Johansson 1999; Jentoft and Stray 2002). However, the positive affection to wooden products is strongly influenced by the perception of a typical wood-odour and needs also to be considered.

The second focus on VOCs of wood material involves several indoor molds and fungi using the wooden substrate for growth, thereby generating additional VOCs being of considerable concern regarding the "sick-building-syndrome" (Mølhave et al. 1997; Johansson 1999; Fischer and Dott 2003; Wilkins et al. 2003; Portnoy et al. 2005; see below and Pemmasani et al. 2007).

\subsection{Volatiles released by fungi}

Fungi are organisms that obtain nutrition by out-of-body digestion, releasing a range of extracellular enzymes to digest their substrates. For degrading wood, they produce cellulases (endo- and exo-cellulases), hemicellulases, $\alpha$-glucosidase and oxidase, phenoloxidases and laccases (Eaton and Hale 1993; Hoegger et al. 2007; Rühl et al. 2007). They further utilise the generated decomposition products for processing metabolism, extending mycelium, and in some cases, developing their fruiting bodies (Kües 2000; Kües et al. 2007). Besides obtaining energy and nutrients, metabolic activity yields also volatile 
by-products including VOCs. This attributes to the typical odour of each fungus. For example, the edible champignon, oyster mushroom, shiitake, puffball, truffle and straw mushroom all have their own individual aromas (Mau et al. 1997; Venkateshwarlu et al. 1999; Mauriello et al. 2004; Zawirska-Wojtasiak 2004; Chiron and Michelot 2005), motivating our appetite. What contributes to these emblematic odours or VOCs? What is their purpose and function? There is still much about the fungal metabolism, especially the secondary metabolism, to uncover.

\subsubsection{Classes of VOCs released by fungi}

VOCs released from wood and wood-decaying fungi range from low to high molecular weight and can be further sub-divided by their chemical structure (Korpi et al. 1998; Gao and Martin 2002; Schleibinger et al. 2005; Chiron and Michelot 2005; Gao et al. 2005; Thakeow et al. 2006) into the eight broad categories of alcohols, aldehydes, ketones, acids, esters, S- and N-containing compounds and isoprenoids (monoterpenes, oxidisedmonoterpenes, sesquiterpenes and oxidised-sesquiterpenes) as listed in Table 2-1.

The un-branched C8 compounds, 1-octen-3-ol, octan-3-one and octan-3-ol, are considered to be typical fungal constituents found in such diverse species as Aspergillus, Fusarium and Penicillium strains (Schnürer et al. 2002), Tuber borcbii, Tuber mesentericum, Tuber excavatum (Mauriello et al. 2004; Menotta et al. 2004), Lentinus sp., Agaricus bisporus, Agaricus campestris, Lactarius sp., and Calvatia sp. (Overton 1994), and wild Polyporus sulfureus and Fistulina hepatica (Wu et al. 2005a,b). However, not only filamentous fungi emit these C8 compounds, but, to a lesser extent, yeasts and bacteria, too (Bruce et al. 2004; Nilsson et al. 2004; Schleibinger et al. 2005). On beech wood, the wood rotting fungi Trametes versicolor, Poria placenta and Gloeophyllum trabeum all released the isoprenoides $\alpha$-pinene, 3carene, longifolene, and cedrene in addition to the alcohols 1-octen-3-ol and octan-3-ol, and the ketone octan-3-one. In addition, each fungus had its own characteristic compounds in the sesquiterpene-class, T. versicolor for example $\alpha$ - and $\beta$-barbartene, G. trabeum high amounts of protoillud-6-ene, and P. placenta fair amounts of daucene (Thakeow et al. 2006). 


\subsubsection{Impact of fungal development on VOCs released by fungi}

VOCs released by fungi can change considerably during their life cycles. For instance, the

VOCs produced by live and dead mycelium of Serpula lacrymans grown on Pinus sylvestris shavings were found to be different. Living mycelium released 1-octen-3-ol as a major volatile component, and dead mycelium 3-methylbutanal and 2-methylbutanal, but only trace amounts of 1-octen-3-ol (Ewen et al. 2004).

Table 2-1 VOC classes as released by wood, infested wood, and micro-organisms (data taken from Korpi et al. 1998; Gao and Martin 2002; Schleibinger et al. 2005; Chiron and Michelot 2005; Gao et al. 2005; Thakeow et al. 2006)

\begin{tabular}{ll}
\hline Chemical categories & Examples \\
\hline Alcohols & ethanol, isopropyl alcohol, octan-1-ol, octan-3-ol, \\
& $\begin{array}{l}\text { 1-octen-3-ol } \\
\text { acetaldehyde, bezaldehyde, furfural, nonanal }\end{array}$ \\
Adehydes & acetic acid, methyl butanoic acids, 2-methyl propanoic acid \\
Acids & acetone, pyranones, hexanones, heptanones, octan-3-one \\
Ketones & ethyl acetate, methyl propanoate \\
Esters & dimethy disulfide, dimethyl trisulfide \\
S-containing compounds & methyl pyrimidine, pyrazine, cyclobutyl amine \\
N-containing compounds & \\
Isoprenoids: & $\alpha-$ pinene, $\beta$-myrcene, 3-carene, limonene \\
Monoterpenes & borneol \\
Oxidised monoterpenes & farnesenes, barbatenes, protoilludenes \\
Sesquiterpenes & longiverbenone \\
Oxidised sesquiterpenes
\end{tabular}

The change of VOCs in sexual development was followed in fruiting bodies of the ascomycete $T$. borchii over four different stages of spore maturation which were defined by the percentage of asci containing mature spores (Zeppa et al. 2004; Table 2-2). The stages differed in number and type of VOCs. Immature asci and asci at the end of sporulation released sesquiterpenes, whereas S-containing compounds are released only at the later stages of ascus development. Interestingly, the sesquiterpene aromadendrene released by the immature ascus was also found produced by T. borchii mycelium grown in the presence 
of its host plant Tilia platyphyllos but not by free-living mycelium (Zeppa et al. 2004). In conclusion, vegetative and reproductive stages of fungal development produce different sets and also quantities of VOCs, likely as a result of the activation of different metabolic pathways. Therefore, VOC patterns can be used as a destruction-free probe system in order to explore biochemical processes underlying developmental processes of the fungi.

Table 2-2 VOCs released from $T$. borchii fruiting bodies during ascus maturation [ascus stage $0: 0-5 \%, 1: 6-30 \%, 2: 31-70 \%$, and $3: 71-90 \%$ of the sets of spores in the asci are mature, respectively (after Zeppa et al. 2004)]

\begin{tabular}{|c|c|c|c|c|}
\hline \multirow[t]{2}{*}{ VOC-Class } & \multicolumn{4}{|c|}{ Ascus stage } \\
\hline & $\mathbf{0}$ & 1 & 2 & 3 \\
\hline Isoprenes & $\begin{array}{l}\text { - 2-methyl-5- } \\
\text { (1,2,2-trimethyl- } \\
\text { cyclopentyl)-, } \\
\text { (S)-phenol } \\
\text { - valencene } \\
\text { - } \alpha \text {-patchoulene } \\
\text { - longiverbenon } \\
\text { e } \\
\text { - cedrene } \\
\text { - aromadendren } \\
\text { e }\end{array}$ & $\begin{array}{l}\text { - longifolen } \\
\text { - } \beta \text {-cedrene } \\
\text { - borneol }\end{array}$ & $\begin{array}{l}\text { - isopino- } \\
\text { camphone } \\
\text { - 3-thujene }\end{array}$ & $\begin{array}{l}\text { - D-limonene } \\
\text { - trans-ocimene } \\
\text { - }(\mathrm{R}) \text { - } \alpha \text {-pinene } \\
\text { - } \alpha \text {-farnesene } \\
\text { 4-isopropyl- } \\
\text { tropolene }\end{array}$ \\
\hline $\begin{array}{l}\text { N-containing } \\
\text { compounds }\end{array}$ & $\begin{array}{l}\text { - 3-(1- } \\
\text { piperazinyl }) \\
\text { propanamide }\end{array}$ & & & \\
\hline $\begin{array}{l}\text { S-containing } \\
\text { compounds }\end{array}$ & & & $\begin{array}{l}\text { - 5-methyl-3H- } \\
\text { pyran-1,2- } \\
\text { dithiol-3-one } \\
\text { - 2-(1,1-dime- } \\
\text { thylethoxy)-5- } \\
\text { methylthiophene }\end{array}$ & $\begin{array}{l}\text { - 3-methyl-thio- } \\
\text { phene } \\
\text { - 2,3-dihydro-5- } \\
\text { methyl-thiophene } \\
\text { - 1-(methylthio)- } \\
\text { 1,3-butadiene } \\
\text { - 2-methyl 4,5- } \\
\text { dihydro-thiophene } \\
\text { - 5-methyl-3H- } \\
\text { pyran-1,2-dithiol- } \\
\text { 3-one } \\
\text { - 5,6-dihydro- } \\
\text { 2H-thiopyran } \\
\text { - ethyl tert-butyl } \\
\text { sulphoxide }\end{array}$ \\
\hline
\end{tabular}




\subsubsection{Impact of substrate on VOCs released by fungi}

Growth and development of fungi are strongly dependent on nutrients and the physical environment (Kües 2000; Chang and Miles 2004), although they can adapt to a broad scale of conditions. Changes in growth conditions influence their metabolisms, resulting in altering VOC patterns (Wheatley et al. 1997; Gao and Martin 2002). For example during spirits production with carbohydrate-rich substrates such as potato or wheat, the yeast Saccharomyces cerevisiae produces ethanol as main product, but the individual substrate provides different and characteristic aroma, caused by the minor components of the yeast and also the substrate (Conner et al. 1998; Pinheiro et al. 2001; Kafkas et al. 2006; Porto et al. 2006).

Some investigations have been carried out on the impact of different media on VOC patterns released by micro-organisms (Wheatley et al. 1997; Bruce et al. 2000, Fiedler et al. 2001; Gao and Martin 2002; Gao et al. 2002; Scotter et al. 2005). Using two main groups of amino acid-rich and carbohydrate-rich media for microbial growth, it was put forward that there are VOCs unique to bacteria and fungi which are called unique microbial volatile organic compounds (UMVOCs) (Gao and Martin 2002). VOCs released from fungi on carbohydrate-rich media are mainly alcohols, acids, aldehydes and ketones. In case of amino acid-rich media, higher quantities of nitrogen (N)- and sulphur (S)containing VOCs are encountered, for instance, cyclobutylamine and dimethyl trisulphide, respectively (Bruce et al. 2004). Zygomycetes, ascomycetes, and deuteromycetes are likely to release the S-containing compound methanethiol when propagating on protein-rich media, in contrast to basidiomycetes (Scotter et al. 2005; Table 2-3). In comparison, bacteria on protein-rich media release also broad ranges of VOCs, most markedly S-containing VOCs like dimethyl trisulfide and heptan-2-one, the latter one independently of the media (Gao and Martin 2002).

Looking closer at molds, substrates have a strong effect on VOC production by different species. When Aspergillus spp. grow on media rich in nutrients, they proceed the normal primary metabolism and release in course alcohols like 3-methyl-1-butanol, 2methyl-1-propanol, 1-octen-3-ol and ketones like octan-3-one. Once the nutrients are ex- 
hausted, the fungi shift to special secondary metabolisms which yields changed VOC patterns. More and other VOCs are released, including terpineol from the terpene group. In case media are amino acid-rich, this leads to production of S-containing VOCs (Fiedler et al. 2001; Gao and Martin 2002). Moreover, some aspergilli can accept sulphur from inorganic substrate and release it in form of dimethyl-disulfide (Gao and Martin 2002). The situation is contrasting in Stachybotrys chartarum, which releases about five times higher quantities of VOCs, when exploiting rich media. VOCs released by $S$. chartarum belong to the group of alcohols, ketones and terpenes. Also Trichoderma spp. (Trichoderma psendokoningii, Trichoderma viride, Trichoderma harzianum) release different VOCs when grown on rich malt extract and poor minimal media, respectively (Wheatley et al. 1997; Fiedler et al. 2001; Humphris et al. 2001). However, no N-containing VOCs are observed, very low amounts of S-containing VOCs (benzothiazole) are released in T. viride, and ethanol is produced in large amounts, independently of the substrate types.

Most wood-rotting fungi belonging to the basidiomycetes on artificial nutrient-rich medium as well as on the natural substrate wood typically release linear aliphatic C8 compounds such as 1-octene, octan-1-ol, 1-octen-3-ol, 2-octenal, 2-octen-1-ol, octan-3one, and octan-3-ol (Rösecke et al. 2000; Ewen et al. 2004).

Table 2-3 Low molecular weight VOCs released from different types of fungi grown on C- and N-rich media, respectively (data from Scotter et al. 2005)

\begin{tabular}{|c|c|c|c|c|c|c|c|c|}
\hline \multirow{2}{*}{$\begin{array}{l}\text { Phylum } \\
\text { Species } \\
\text { Media }\end{array}$} & \multicolumn{2}{|c|}{$\begin{array}{c}\text { Zygomycete } \\
\text { Mucor } \\
\text { racemosus }\end{array}$} & \multicolumn{2}{|c|}{$\begin{array}{l}\text { Ascomycete } \\
\text { Apergillus spp. }\end{array}$} & \multicolumn{2}{|c|}{$\begin{array}{l}\text { Deuteromycete } \\
\text { Fusarium } \\
\text { solani }\end{array}$} & \multicolumn{2}{|c|}{$\begin{array}{c}\text { Basidiomycete } \\
\text { Cryptococcus } \\
\text { neoformans }\end{array}$} \\
\hline & $\begin{array}{c}\mathrm{C}- \\
\text { rich }\end{array}$ & $\begin{array}{l}\mathrm{N}- \\
\text { rich }\end{array}$ & $\begin{array}{l}\mathrm{C}- \\
\text { rich }\end{array}$ & $\begin{array}{l}\mathrm{N}- \\
\text { rich }\end{array}$ & $\begin{array}{c}\mathrm{C}- \\
\text { rich }\end{array}$ & $\begin{array}{l}\mathrm{N}- \\
\text { rich }\end{array}$ & $\begin{array}{l}\mathrm{C}- \\
\text { rich }\end{array}$ & $\begin{array}{l}\mathrm{N}- \\
\text { rich }\end{array}$ \\
\hline \multicolumn{9}{|l|}{ VOCs } \\
\hline Ethanol & + & + & + & + & + & + & + & + \\
\hline Acetaldehyde & - & + & - & + & + & - & + & + \\
\hline Acetone & - & + & - & + & - & - & + & - \\
\hline Methanethiol & - & + & - & + & - & - & - & - \\
\hline
\end{tabular}

+ found, - not found 
These examples from the literature document that VOCs released by micro-organisms are certainly useful to distinguish different groups and even species, but environmental and physiological conditions have to be considered. In order to gain a more consistent picture about growth conditions (temperature, humidity and light), kind of media and developmental stages have to be clearly and in depth addressed in research, since these factors strongly affect the metabolism, leading consequently to changes in VOC patterns (Table 2-4).

\subsection{Volatiles released by fungus-infested wood}

As discussed already above, VOCs released from fungi are strongly dependent on substrates and the stage of the life cycle and development. Wood as a substrate for wooddecaying fungi can be expected to influence the fungal metabolism. Fungi attack and colonise wood in different ways, depending on the properties of the wood. Wood as a substrate can be living or dead - namely in form of a standing tree, a felled tree, storage wood and wood in service, respectively -, engaging more or fewer living cells in the wood with the ability to render the substrate. When standing in the forest, the tree is a suitable nutrition source for fungi since it contains nutrients like sugars, amino acids and minerals. Anyway, when fungi infect a living tree, they have to adapt to or protect themselves against the tree defense system. In dead wood in contrast, most defence systems of the tree are not anymore active. However, dead wood provides less free sugar and amino acids, and more polymerised substrate which is more difficult to digest. Therefore, when fungi are growing on living or dead wood, the fungal metabolism and, thus, the fungal VOC patterns will be differentially affected. Besides nutrient contents, the water content of the wood is also severely affecting fungal growth and development, why in European standard EN 335-1 (1992) the hazard class for fungal decay is related to the water content in wood. 
Table 2-4 VOCs released by micro-organisms (data taken from Wheatley et al. 1997; Bruce et al. 2000, 2004; Fiedler et al. 2001; Gao and Martin 2002; Gao et al. 2002; Scotter et al. 2005)

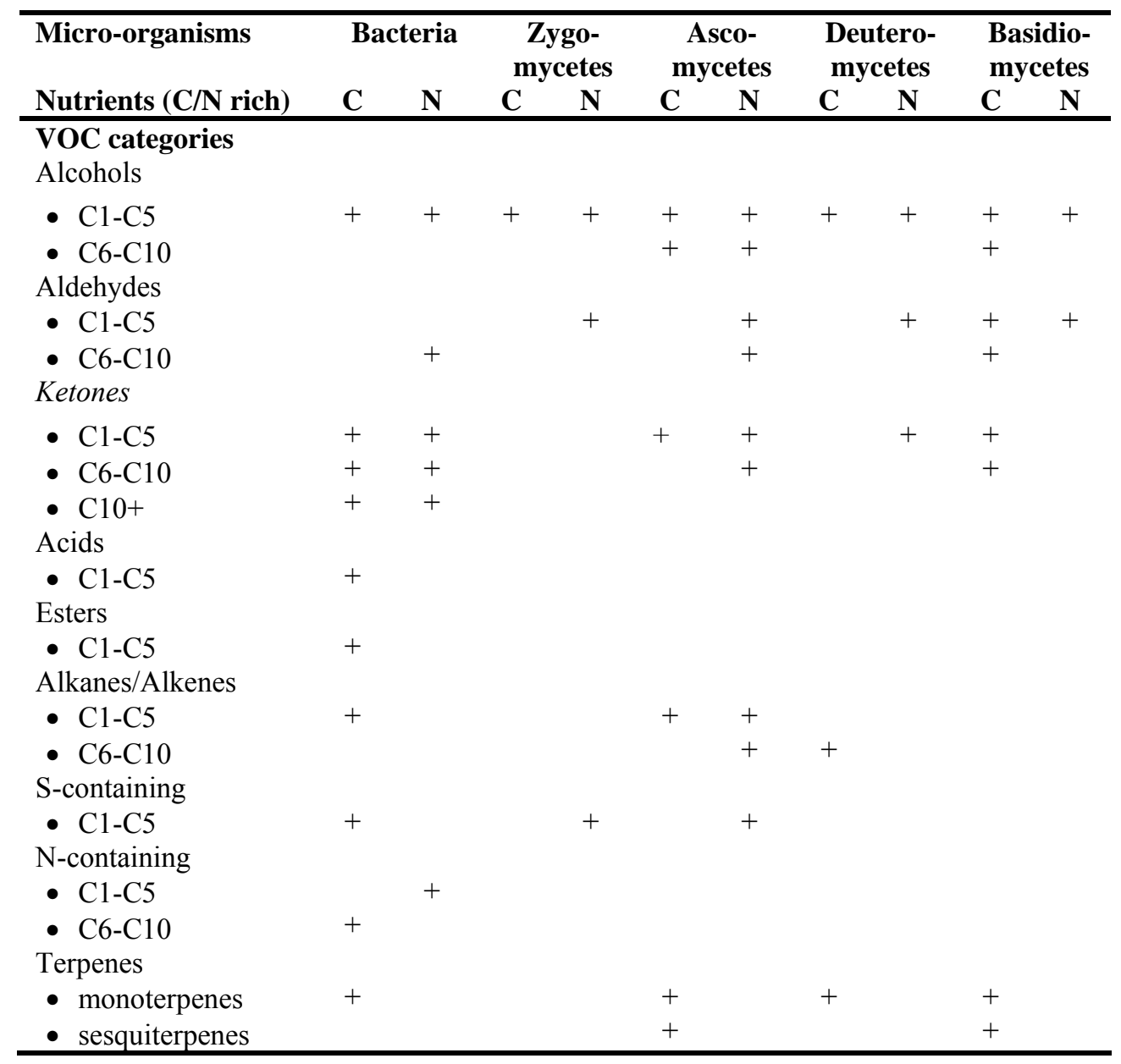

Most fungi that infest and decay wood belong to the phylum of basidiomycetes, more precisely to the class of homobasidiomycetes. These wood-decaying fungi are divided into two main types, brown- and white-rot fungi, respectively, according to the colour of the wood in an advanced stage of decay. This difference results from their ability to degrade lignin. Brown rot fungi can degrade all components in wood but lignin. The left-over phenolic substrate lignin turns brown in colour. In contrast, white rot fungi can degrade all 
types of wood components, even lignin. Their decay mechanism resembles the action of a bleaching agent resulting in whitish-stained cellulose as left-over from the wood (Hoegger et al. 2007). Another type of fungi softens the cell walls of wood by decay reactions. Such species are therefore called soft-rot fungi and they belong mostly to the phylum of ascomycetes. So far however, little is known between the effect of different rotting abilities of fungi and the release of respective VOC patterns (Thakeow et al. 2006).

\subsection{Sick building syndrome (SBS) as a consequence of VOCs}

When micro-organisms infest buildings, they may produce a potentially hazardous environment. Individuals exposed to environments that contain high concentrations of airborne contaminants from microbial organisms report health symptoms including eye and sinus irritation, headache, nausea, fatigue, congestion, sore throat, and even toxic poisoning. The term "sick-building syndrome" (SBS) was first coined in the mid-1980s referring to ill-health symptoms arising from poor indoor air quality, that further on have been frequently correlated with the presence of fungi (Ahearn 1996). Current methods for detecting microbial contamination include air and material sampling with fungal culture analysis, air sampling coupled with gas chromatography-mass spectrometry, and visual inspection (Pasanen 1992; Schiffman et al. 2001). Several micro-organisms infest buildings and release microbial volatile organic compounds (MVOCs). Typical fungi are of the genera Aspergillus/Eurotium, Penicillium, Cladosporium, Trichoderma and Stacbybotris. MVOCs released are mainly alcohols (pentanoles, hexanoles, octanoles), ketones (hexanones, heptanones, octanones), and a few $\mathrm{N}$ - and S-containing compounds (pyrazine and dimethylsulfide, respectively) (Wilkins et al. 2003; Nilsson et al. 2004; Schleibinger et al. 2005).

Besides contaminants released by micro-organisms, wooden buildings themselves also release VOCs which contribute to SBS. VOCs released from several wood species were examined (Risholm-Sundman et al. 1998), i.e., ash, beech, maple, birch, oak, cherry, rubber wood, pine and spruce. Acetic acid, a compound of corrosive nature, was emitted from 
every wood species, except pine and spruce. In contrast, terpenes are generally released from pine and spruce wood. Especially 3-carene may irritate skin and mucous membranes. Allergy and chronic lung function impairment might be elicited after prolonged exposure (Falk et al. 1991).

\subsection{What is the role of VOCs for insects?}

Wood is the basis of existence for adapted fungi and insects, influencing each other's living conditions. In the context of the trophic interaction between wood, insects, and fungi, we have seen the functions of the participants and the variation within. Wood can be living or dead, actively or passively defensive. It can be infested by specific insects and/or fungi-under indoor and outdoor environments. Insects can follow just wood VOCs (Weissbecker et al. 2004), fungal VOCs (Fäldt et al. 1999; Holighaus and Schütz 2006) or defense signals (Schütz and Weißbecker 2003). On the one hand, this broad and diverse information is a basis for diverse evolutionary development, marking ecological partitioned niches and suitable environments for hosting species such as insects. On the other hand, this requires a high plasticity of appendant organisms as receivers of the available chemical information (Johne et al. 2003, 2006a). Hence, relying on common VOCs keeps flexibility in a changing and dynamic environment whereas relying on a specific VOC as a kind of marker compound for suitable host plants represents the advantage of highly specific adaptation. Thus, research on a multitrophic system using VOCs as information needs advanced techniques in trace analysis and interpretation (Weissbecker et al. 2004). Sometimes, the crucial information is small and silent, maybe hidden behind abundant noises. 


\subsection{VOCs mediating insect interaction with trees, wood and fungi}

\subsubsection{Insects on living trees}

Insects attacking living trees use the typical host VOCs released by the tissue sought after. In stems of conifers, for example, several monoterpenes such as $\alpha$-pinene, $\beta$-myrcene, terpinolenes and $\beta$-pinene are attractive to a large number of conifer inhabiting beetles: an overview of the chemical ecology of bark beetles (Scolytidae) in this complex olfactory landscape is given by Byers (2004), of weevils (Curculionidae) by Schlyter (2004), of longhorn beetles (Cerambycidae) by Allison et al. (2004), and of jewel beetles (Buprestidae) by Schütz et al. (1999a, 2004). The influence of VOCs on insect behaviour is well studied in the case of Picea abies in the context of infestation with the bark beetle Ips typographus. A cascade of VOCs is released during the process of infestation and colonisation by the beetle: primary attractive VOCs from the bark draw beetles to a weakened tree, followed by production and release of aggregation pheromones by the insects. Subsequently, the release of VOCs from the tree indicating exhaustive overuse of the plant resource leads to repulsion and dispersal of the beetles (Byers 2004). The prospect of successful infestation led obviously during evolution to a high sensitivity of tree invading insects to VOC signals related to different stress factors. Defence reactions of the tree become transparent through shifts in VOC abundance and composition (Petterson and Boland 2003; Schütz et al. 2004). Franceschi et al. (2005) reviewed defence aspects by the wood anatomy influencing chemical defences against insects and blue-staining fungi. Both, anatomical and chemical defense turn out to be strongly interlinked (Hudgins et al. 2004; Erbilgin et al. 2006; Zeneli et al. 2006).

\subsubsection{Fungus-insect interaction on trees, trunks and deadwood}

Fungi often participate in tree-insect-interactions. These interactions with trees and wood are reviewed by various authors in the past (e.g. Buchner 1953; Wilding et al. 1989; Vega and Blackwell 2005). Insects can be a vector of fungi (Paine et al. 1997), feed on the fungi degrading wood (Mueller et al. 2005), or even host endosymbiotic fungi for wood 
digestion (Buchner 1953). Especially many xylophageous insects feeding on deadwood coevolved with fungi to complex symbiotic coenosis (Douglas 1989; Klepzig et al. 1996; Dillon and Dillon 2004). Enzymatic detoxification abilities of these endosymbiotic fungi make otherwise protected lignocellulosic resources accessible - not at least hence, these fungi and their enzymes are of commercial interest (Dowd 1992). Conversely, because of competition for the same resource volatiles from wood decaying fungi can be repellent for insects (Johne et al. 2006a) or toxic fungal metabolites (VOCs and non-VOCs) may keep insects away from the wood (Seybold et al. 2006). Overall, even healthy trees are not aseptic. Fungal interactions with living trees are known in forms of latent infections of the xylem or endophytic colonisations of leaves (Hendry et al. 2002), not to mention the symbiotic mycorrhiza (van der Heijden and Sanders 2002). In the xylem of European beech, for example, Hypoxylon fragiforme was identified as a latent invader besides other casual inhabitants (Hendry et al. 2002). Chemotaxonomic studies of this species give hints to metabolites released by the fungus (Stadler et al. 2004). However, up to now there are no data about chemical reactions, resultant VOCs, or insect preferences emerging from this type of fungus-tree interaction.

The insects related to tree trunks can be grouped roughly into phloem- and xylemfeeders. Phloem is rich in nutrients but strongly shielded by the active plant defense system and xylem is hard to digest but less protected (Lieutier 2004). Fungi can play a fundamental role for both groups of insects to overcome the respecttive defensive systems (Dowd 1992). Moreover, insects may feed on fungi utilising the ability of fungi to catabolise cellulose (Watanabe and Tokuda 2001). Some xylophagous or deadwood insects are therefore grouped as mycetophagous insects, too (Bouget et al. 2005). For example, the family of bark beetles (Scolytidae) with worldwide about 6000 species presents a huge variability of associations with trees and fungi (Jacobs and Wingfield 2001; Kolařík et al. 2005). These beetles differ widely in their ecology and biochemical adaptations to their host trees. Within this taxonomic group are phloem- and xylem feeders, ambrosia beetles with a compulsive association to symbiotic fungi and there are also several facultative connections between bark inhabiting insects and fungi (Farrell et al. 2001; Aukema et al. 2005; Mueller et al. 2005). The majority of Scolytidae are phloem-feeders with obviously 
mutualistic relationships to their fungal associates but the strength of interaction is still subject of considerable debate. Several cases are known where insects act as vectors of serious fungal pests, most noticeable when non-indigenous, newly introduced, and thus not adapted to a given environment (Harrington et al. 2001; Allen and Humble 2002). Many fundamental aspects of the degree of dependence in such insect-fungus relationships are however still poorly known (Kirisits 2004). A strong relationship to fungi is known in the scolytid xylophagous ambrosia beetle Trypodendron domesticum and the lymexylid Hylecoetus dermestoides which both infest the xylem of F. sylvatica trees. They follow the first chemical hints of weakness in living and especially freshly cut trees and initiate ongoing decay processes by introducing several associated "ambrosia" fungi (Farrell et al. 2001; Holighaus and Schütz 2006). VOCs are the main signals for these beetles obtaining information about precise decay and defence status of trunk patches (Holighaus and Schütz 2006). Electrophysiological techniques (EAG = electroantennography) use insect antennae, which are often much more sensitive to VOCs than trace analytical methods, to locate within the hundreds of VOCs those, carrying the information of suitability. General and omnipresent VOCs are little informative. Others correlate with general plant physiological processes and are therefore useful for an assessment of suitability of a trunk as breeding substrate. Further VOCs give highly specific information of e.g. certain fungal species colonising the wooden substrate which can be indispensable for insect development and hence lead to attraction (Belmain et al. 2002), or which are even fatal and have to be avoided. Evolution eventually led to highly specific adaptations which turned VOCs into triggers of these complex interactions. By observing these sensitive signals with analytical techniques, we can obtain the state of wood in aging, decaying and the status of interaction or infestation with fungi and insects (Weissbecker et al. 2004; Holighaus and Schütz 2006; Thakeow et al. 2006). 


\subsubsection{Insects on wood and wooden products}

Not all insects feeding on wooden substrate necessarily need fungal associates. There are species without as Ergates faber (Cerambycidae), producing own endogenous cellulases. This ability for cellulose degradation is found sometimes in other insect families, too, for example in cockroaches (Blattaria) and termites (Isoptera) (Douglas 1989; Watanabe and Tokuda 2001). Beside "wood worms" which are larvae from the family of Anobiidae, the old house borer Hylotrupes bajulus (Cerambycidae) is a widespread insect pest of coniferous timbers in buildings. Without any fungal support it can cause substantial damage to roof timbering or framework houses even in temperate climate. An understanding of the volatiles relevant for the orientation of $H$. bajulus could help to find new methods for protection of wood and a control of the beetle (Reddy et al. 2005a). H. bajulus is very delicate in the choice of sites for mating and oviposition and obviously, it is guided by olfactory cues. Recent behavioural studies assigned importance to monoterpenoid hydrocarbons as attractants (Fettköther et al. 2000; Reddy et al. 2005b). A direct investigation of the olfactory response of $H$. bajulus to original odour samples of its host trees by GC$\mathrm{EAD} / \mathrm{MS}$ yielded a more complex mixture of terpenes, aldehydes, alcohols and other hydrocarbons as VOCs being important to H. bajulus (Weissbecker et al. 2004). This knowledge will be crucial for the assessment of thermal wood treatments or chemical wood modification techniques for protecting constructional wood without any poisonous chemicals, just by reducing olfactory traceability and attraction for the old house borer.

Siricid woodwasps (Siricidae) (Thomsen and Koch 1999) and Anobiidae, like the death watch beetle Xestobium rufovillosum (Belmain et al. 2002), are xylophagous insects which have acquired fungal associates and cause substantial damage on wood and wooden products prior and during service. Both are examples for endosysmbiotic relationships to fungi. Ambrosia beetles (Holighaus and Schütz 2006), as described above, are known for ectosymbiotic relationships. In termite-species (Isoptera), (Brune and Friedrich 2000) both types of symbiosis can be found. 


\subsubsection{Insects on fungi}

Other beetles, for instance of the family of Cisidae, do not bother to prepare the wood for symbiotic fungi but just feed in more or less specialised manner on fruiting bodies of bracket fungi (Jonsell and Nordlander 2004). Fomitopsis pinicola and Fomes fomentarius, bracket fungi growing on tree trunks of Pinus and Fagus species, respectively, were shown to release C8 compounds, such as 1-octene, octan-1-ol, octan-3-ol, 2-octene-1-ol, and 1octen-3-ol, and sesquiterpenes such as $\beta$-barbatene. The cisid beetles Cis glabratus and Cis quadridens can discriminate the host odour of fruiting bodies of F. pinicola and F. fomentarius, respectively (Fäldt et al. 1999). Moreover, predatory Anaspidae feeding on cisid beetles, namely Anaspis marginicollis, Anaspis rufilabris and Epinotia tedella, were significantly attracted to 1-octen-3-ol released predominantly by damaged fruiting bodies of the bracket fungi (Fäldt et al. 1999). These different degrees of specialisation in insects for fungus infested wood might be used in biomimetic sensor systems for the assessment of wood with respect to fungal infestation.

\subsection{Techniques for assessing wood quality on the basis of VOCs}

It is a bionic concept to utilise VOCs as a parameter for wood quality assessment: This concept is inspired by the impressive achievements of insects in performing this task just by olfaction and taste. However, the approaches to copy these "inventions of nature" are so far sparse.

\subsubsection{Biosensors}

The selectivity and sensitivity of biological recognition processes motivated the development of biosensors. Biosensors are miniature measuring devices consisting of a biological recognition component in close spacial and functional contact with a physical transducer unit. The biocomponent utilised can be of different levels of organisation: whole (micro-) organisms in organismic biosensors, whole sensory systems in biosensors on the basis of 
sensory organs, and enzymes, antibodies, or receptor-proteins as well as nucleic acids in bio-molecular biosensors. The physical transduction unit is needed to transduce analyte caused changes of the biocomponent (heat, mass, light, resistance, capacity, current, potential, ...) into output signals that can be processed by electronic data processing units (Wollenberger et al. 2000; Pemmasani et al. 2007).

Biosensors for detecting volatile compounds principally fight the problem that biocomponents tend to deteriorate when exposed to air. Especially biomolecules have to be protected by membranes which are hindering diffusion of VOCs and thus, compromising sensitivity. Hence, most biosensors utilising biomolecules as a biocomponent are relying on extraction of VOCs by aqueous solvents, as it is done for the amperometric enzyme biosensor for detecting phenolic compounds from wood pulp (Rosatto et al. 2001), and the amperometric enzyme biosensor for the assessment of wood ageing (Campanella et al. 2005).

In contrast, biosensors on the basis of immobilised micro-organisms show considerable working stability in air. One major field for these biosensors is the measurement of complex parameters like toxicity. Biosensors for the toxicity of VOCs using recombinant bioluminiscent Escherichia coli bacteria (Gil et al. 2000; Mwinyihija et al. 2005) or different strains of algae (Podola et al. 2004) were designed, which might be applicable for wood quality assessments with regard to potential health implications of wood materials. Moreover, biosensors on the basis of immobilised micro-organisms were proposed for the analysis of fermentation characteristics of spoilage micro-organisms (Wang and Wang 2002). This proposal was picked up utilising a potentiometric biosensor based on immobilised yeast cells (Rotariu et al. 2004), and for the analysis of microbial communities utilising an array of electrochemical microsensors and microscale biosensors selectively responding to volatile fatty acids based on immobilised bacteria (Meyer et al. 2002; Revsbech 2005). These biosensors might be applicable for wood quality assessments with regard to microbial infestation and degradation. 
Biosensors on the basis of insect olfaction provide unrivalled measuring rates, selectivity and sensitivity in the analysis of VOCs in air (Schroth et al. 1999). Integrating ecological and behavioural observations with electrophysiological measurements of antennal responses to VOC mixtures corresponding to specific situations (for instance: forest fires) yielded sets of insect antennae and marker compounds for the detection of these situations. The black jewel beetle (Melanophila acuminata) was found to be attracted by forest fires, because burnt wood is the only suitable substrate for bringing up its offspring. The antennae of the black jewel beetle were proved to be highly sensitive and selective to guaiacol derivatives, compounds which are generated by the pyrolysis of wood (Schütz et al. 1999a). The antennae and with them the set of detected compounds can thus be appointted by the biosensor-designer to assess wood species and fire parameters (temperature, oxygen access) involved in the forest fire in distances of kilometres (Schütz 2004). A few of the compounds recorded by the beetle's antennae are recognised to be of special interest to coopers' thermally modified oak wood used to produce barrels for wine storage (Chatonnet et al. 1999; Campbell et al. 2005), identifying a promising field of application for such a biosensor in process and quality control of thermally modified wood. Thermal and chemical wood modification is recently discussed to replace treatments of construction wood with poisonous biocides (Mai and Militz 2007). The house borer $H$. bajulus is one of the major reasons for this problematic biocide treatment (see above). Besides terpenes, there are aldehydes involved in detection and classification of wood by the beetle (Weissbecker et al. 2004). A biosensor on the basis of the antennae of H. bajulus can be useful to assess the VOC patterns generated by different wood modification techniques with regard to the detectability and acceptability of treated wood by this dangerous beetle.

The detection and characterisation of fungal infestation and decay in construction wood prior to and during service is another important task by the fact that fungal infestation can have deleterious impacts on the mechanical stability of construction wood. According to their ecology and behaviour, different insect antennae respond differentially to microbial VOCs. However, virtually every insect examined responds to branched and linear C-8 compounds as markers for microbial activity (Fäldt et al. 1999; Schütz and Weißbecker 2003; Holighaus and Schütz 2006). With this knowledge, biosensors on the 
basis of insect antennae for the infestation by micro-organisms were established (Schütz et al. 1999b). Despite the high performance of this kind of biosensors, their field of application is limited to on-site-measurements because of the limited life-time of the biocomponent antennae, ranging from hours to days. Further development of biomimetic sensors employing key principles of stablisation, pre-filtering and recognition of insect olfaction will be necessary in order to extend life time and availability of sensor devices on the basis of insect olfaction (Schütz et al. 2001).

\subsubsection{Electronic noses}

The biological olfactory system inspired furthermore the development of electronic nose technology. An electronic nose is a machine that is designed to detect and discriminate complex mixtures of VOCs (odours) using a sensor array (Eberheim et al. 2004). The sensor array consists of broadly tuned (non-specific) sensors that are treated with a variety of odour-sensitive biological or chemical materials. An odour stimulus generates a characteristic fingerprint from the sensor array. Patterns or fingerprints from known odours are used to construct a database and train a pattern recognition system so that odours within the trained range can subsequently be classified and identified. Thus, electronic nose instruments are comprised of hardware components to collect and transport odours to the sensor array as well as electronic devices to digitise and store the sensor responses for signal processing (Pearce et al. 2003).

The pulp and paper industries in eastern Canada need to differentiate black spruce, balsam fir, and jack pine because their proportions in wood chips affect the quality of the pulp and paper produced. A prerequisite to determine their proportions is to be able to rapidly identify the wood of the three conifers. Using a combination of marker compounds and GC profiles of hexane extracts made a distinction even of the sapwood of these tree species possible (Pichette et al. 1998). However, this initial method is too slow and expensive to be used by paper mills. A more advanced electronic nose consisting of 32 conducting polymer sensors (Cyranose ${ }^{\mathrm{TM}} 320$ ) was able to rapidly discriminate and identify black spruce, balsam fir and jack pine wood chips, utilising principal component 
analysis as a data analysis tool (Hobbs et al. 2000; Garneau et al., 2004). In another application, thermally modified oak wood for wine barrels was assessed regarding its toasting level by an electronic nose consisting of 6 metal oxide semiconductor sensors utilising principal component analysis, discriminant function analysis and neuronal network techniques for data analysis (Chatonnet 1999).

The growth of bacteria and fungi on organic matter generates a broad range of VOCs (see above). Most studies with electronic noses deal with the detection and classification of bacteria (Holmberg 1997; Gardner et al. 1998), using sensor-arrays consisting of six to nine metal oxide semiconductor gas sensors. Few reports are available for fungal detection: with an accuracy of $93 \%$ six spoilage fungi of meat (four Eurotium spp., each one Penicillium and Wallemia species) were classified on blood agar 24 hours after infestation and prior to visible growth, using an electronic nose consisting of 14 polymer sensors (Keshri et al. 1998). With the same electronic nose, seven homobasidiomycetes (Agaricus arvensis, A. bisporus, A. campestris, Agaricus maleolens, Agaricus nivescens, Pleurotus sajor-caju, and Volvariella bombycina) were differentiated (Keshri et al. 2003). Twenty-four hours after their inoculation on rich potatodextrose-agar (PDA) and a minimal medium (Czapek-Dox agar), 5 fungi suspected to be involved in SBS (Aspergillus flavus, Aspergillus niger, Cladosporium cladosporioides, Penicillium chrysogenum, and $S$. chartarum) were detected and classified by an electronic nose designed at North Carolina State University (NC State E-Nose) consisting of 15 metal oxide sensors. The classification was independent on type of the growth medium. The raw data of this analysis were transferred to an electronic data processing system. They were first compressed using windowing functions which provided a set of four features for each sensor. Lineardiscriminant analysis was then applied to the compressed data to maximise class separability. Sixty percent of the compressed data were randomly selected to form a training set for the classification algorithms. K-nearest-neighbours (KNN) and least-squares (LS) techniques were both employed to classify the remaining $40 \%$ of the compressed data. The KNN technique resulted in $90 \%$ accuracy of species identification after the first day of inoculation (Schiffman et al. 2000). 


\subsection{Outlook}

Bionic noses integrate two different approaches by copying algorithms used by nature in odour perception on different level of organisation. Biosensors selectively tuned to marker compounds are amended by algorithms of electronic noses operating with an array of broadly tuned chemical sensors in order to discriminate complex situations based on a set of marker compounds.

As a complex sensing device, an insect antenna can serve as a blueprint for technical sensor optimisation in a "constructive bionics" approach, using for instance the principles of the porous cuticle for sample enrichment, as shelter against air and dust, and as a chemical pre-filter. Algorithms used by insects for contrast enhancement in odour mixture recognition can be exploited as a source of inspiration in an "informational bionics" approach. The identification of marker compounds or pattern recognition algorithms from sensory ecology of insects interacting with wood and degrading micro-organisms might serve as a guideline in a "process bionics" approach in the development of new bionic sensors for wood assessment. Thus, in the near future the possibilities in wood assessment can be considerably extended by thorough application of a bionics/biomimetic approach.

\section{Acknowledgements}

This work was supported by the German Science Foundation and the Federal Minister of Research and Technology through several projects and by the Royal Thai Government and the Chiang Mai University through a PhD fellowship awarded to PT.

\subsection{References}

Ahearn DG. 1996. Fungal colonization of fiberglass insulation in the air distribution of a multistory of ice building: VOC production and possible relationship to sick building syndrome. Journal of Industrial Microbiology and Biotechnology 16: 280-285.

Allen EA, Humble LM. 2002. Nonindigenous species introductions: A threat to Canada's forests and forest economy. Canadian Journal of Plant Pathology 24: 103-110. 
Allison JD, Borden JH, Seybold SJ. 2004. A review of the chemical ecology of the Cerambycidae (Coleoptera). Chemoecology 14: 123-150.

Apel K-H, Kätzel R, Lüttschwager D, Schmitz H, Schütz S. 1999. Untersuchungen zu möglichen Mechanismen der Wirtsfindung durch Phaenops cyanea F. (Col., Buprestidae). Mitteilungen der Deutschen Gesellschaft für allgemeine und angewandte Entomologie 12: 23-27.

Arimura GI, Ozawa R, Nishioka T, Boland W, Koch T, Kühnemann F, Takabayashi J. 2002. Herbivore-induced volatiles induce the emission of ethylene in neighbouring lima bean plants. Plant Journal 29: 87-98.

Asakawa Y. 2004. Chemosystematics of the Hepaticae. Phytochemistry 65: 623-669.

Aukema BH, Werner RA, Haberkern KE, Illman BL, Clayton MK, Raffa KF. 2005. Quantifying sources of variation in the frequency of fungi associated with spruce beetles: implications for hypothesis testing and sampling methodology in bark beetle-symbiont relationships. Forest Ecology and Management 217: 187-202.

Barry AO, Corneau D. 1999. Volatile organic chemicals emissions from OSB as a function of processing parameters. Holzforschung 53: 441-446.

Belmain SR, Simmonds MSJ, Blaney WM. 2002. Influence of odor from wood-decaying fungi on host selection behavior of deathwatch beetle, Xestobium rufovillosum. Journal of Chemical Ecology 28: 741-754.

Bleich S, Hapla F, Sprung R. 1998. Possible risk to develop nasal cancer by occupational exposure to wood dust containing methanol and methylacetate. Investigations of wood dust using headspace gas chromatography. Holz als Roh- und Werkstoff 56: 367-372.

Blokhina O, Virolainen E, Fagerstedt KV. 2003. Antioxidants, oxidative damage and oxygen deprivation stress: a review. Annals of Botany 91: 179-194.

Bouget C, Brustel H, Nageleisen L-M. 2005. Nomenclature of wood-inhabiting groups in forest entomology: synthesis and semantic adjustments. [Nomenclature des groupes écologiques d'insectes liés au bois: Synthèse et mise au point sémantique]. Comptes Rendus - Biologies 328: 936-948.

Brune A, Friedrich M. 2000. Microecology of the termite gut: Structure and function on a microscale. Current Opinion in Microbiology 3: 263-269.

Bruce A, Wheatley ER, Humphris NS, Hackett CC, Florence EJM. 2000. Production of volatile organic compounds by Trichoderma in media containing different amino acids and their effect on selected wood decay fungi. Holzforschung 54: 481-486.

Bruce A, Verrall S, Hackett AC, Wheatley ER. 2004. Identification of volatile organic compounds (VOCs) from bacterial and yeast causing growth inhibition of sapstain fungi. Holzforschung 58: 193-198.

Buchner P. 1953. Endosymbiose der Tiere mit pflanzlichen Mikroorganismen. Publisher: Birkhäuser, Basel, Switzerland.

Burt S. 2004. Essential oils: their antibacterial properties and potential applications in foods - a review. International Journal of Food Microbiology 94: 223-253.

Byers JA. 2004. Chemical ecology of bark beetles in a complex olfactory landscape. In: Lieutier F, Day KR, Battisti A, Grégoire J-C. (Eds.) Bark and wood boring insects in living trees in Europe: a synthesis. Kluwer Academic Publisher, Boston, MA, pp. 89-134.

Campanella L, Chicco F, Favero G, Gatta T, Tomassetti M. 2005. Further applications of a new biosensor method for dating cellulosic finds. Annali di Chimica 95: 1-10. 
Campbell JI, Sykes M, Sefton MA, Pollnitz AP. 2005. The effects of size, temperature and air contact on the outcome of heating oak fragments. Australian Journal of Grape \& Wine Research 11: 348-354.

Chang ST, Miles GP. 2004. Mushrooms: Cultivation, nutritional value, medicinal effect and environmental impact, $2^{\text {nd }}$ edition. Chapter 4: Overview of the biology of fungi. CRC Press, New York. pp. 53-144.

Chatonnet P. 1999. Discrimination and control of toasting intensity and quality of oak wood barrels. American Journal of Ecology and Viticulture 50: 479-494.

Chatonnet P, Cutzach I, Pons M, Dubourdieu D. 1999. Monitoring toasting intensity of barrels by chromatographic analysis of volatile compounds from toasted oak wood. Journal of Agricultural Food Chemistry 47: 4310-4318.

Chiron N, Michelot D. 2005. Mushroom odours, chemistry and role in the biotic interactions a review. Cryptogamie Mycologie 26: 299-364.

Conner JM, Birkmyre L, Paterson A, Piggot JR. 1998. Headspace concentrations of ethyl ester at different alcoholic strengths. Journal of the Science of Food and Agriculture 77: 121126.

de Bruxelles GZ, Roberts MH. 2001. Signals regulating multiple responses to wounding and herbivores. Critical Reviews in Plant Sciences 20: 487-521.

Dillon RJ, Dillon VM. 2004. The gut bacteria of insects: nonpathogenic interactions. Annual Review of Entomology 49: 71-92.

Dindorf T, Kuhn U, Ganzeveld L, Schebeske G, Ciccioli P, Holzke C, Köble R, Seufert G, Kesselmeier J. 2005. Emission of monoterpenes from European beech (Fagus sylvatica L.) as a function of light and temperature. Biogeosciences Discussions 2: 137-182.

Douglas AE. 1989. Mycetocyte symbiosis in insects. Biological Reviews - Cambridge Philosophical Society 64: 409-434.

Dowd PF. 1992. Insect fungal symbionts: a promising source of detoxifying enzymes. Journal of Industrial Microbiology 9: 149-161.

Dudt JF, Shure DJ. 1994. The influence of light and nutrients on foliar phenolics and insect herbivory. Ecology 75: 86-98.

Eaton RA, Hale MDC. 1993. Wood: decay, pests and protection. Chapman \& Hall, London, UK.

Eberheim A, Schieberle P, Schütz S, Kohl D. 2004. Fire recognition based on new technologies. Abstracts of the XXII International Conference of Entomology in Brisbane, Australia 15.-21. August 2004 (unpaged).

EN (European standard) 335-1. 1992. Durability of wood and wood-based products Definition of hazard classes of biological attack - Part 1: General (in revision).

Engelberth J, Alborn HT, Schmelz EA, Tumlinson JH. 2004. Airborne signals prime plants against insect herbivore attack. Proceedings of the National Academy of Sciences of the United States of America 101: 1781-1785.

Erbilgin N, Krokene P, Christiansen E, Zeneli G, Gershenzon J. 2006. Exogenous application of methyl jasmonate elicits defenses in Norway spruce (Picea abies) and reduces host colonization by the bark beetle Ips typographus. Oecologia 148: 426-436.

Ewen JR, Jones RHP, Ratcliffe MN, Spencer-Phillips TNP. 2004. Identification by gas chromatography-mass spectrometry of the volatile organic compounds emitted from the wood-rotting fungi Serpula lacrymans and Coniophora puteana, and from Pinus sylvestris timber. Mycological Research 7: 806-814. 
Fäldt J, Jonsell M, Nordlander G, Borg-Karlson KA. 1999. Volatiles of bracket fungi Fomitopsis pinicola and Fomes fomentarius and their functions as insect attractants. Journal of Chemical Ecology 25: 567-589.

Falk A, Löf A, Hagberg M, Hjelm EW, Wang Z. 1991. Human exposure to 3-carene by inhalation: toxicokinetics, effects on pulmonary function and occurrence of irritative and CNS symptoms. Toxicology and Applied Pharmacology 110: 198-205.

FAO (Food and Agricultural Organisation of the United Nations). 2006. Global forest resources assessment 2005 - Progress towards sustainable forest management. FAO Forestry Paper, 147, Rome, Italy.

Farag MA, Fokar M, Abd H, Zhang H, Allen RD, Paré PW. 2005. (Z)-3-Hexenol induces defence genes and downstream metabolites in maize. Planta 220: 900-909.

Farrell BD, Sequeira AS, O'Meara BC, Normark BB, Chung JH, Jordal BH. 2001. The evolution of agriculture in beetles (Curculionidae: Scolytinae and Platypodinae). Evolution 55: 2011-2027.

Fehsenfeld F, Calvert J, Fall R, Goldan P, Guenther AB, Hewitt CN, Lamb B, Liu S, Trainer M, Westberg H, Zimmermann P. 1992. Emissions of volatile organic compounds from vegetation and the implications for atmospheric chemistry. Global Biogeochemical Cycles 6: 389-430.

Fettköther R, Reddy GVP, Noldt U, Dettner K. 2000. Effect of host and larval frass volatiles on behavioural response of the old house borer, Hylotrupes bajulus (L.) (Coleoptera: Cerambycidae), in a wind tunnel bioassay. Chemoecology 10: 1-10.

Feussner I, Wasternack C. 2002. The lipoxygenase pathway. Annual Review of Plant Biology 53: $275-297$.

Fiedler K, Schütz E, Geh S. 2001. Detection of microbial volatile organic compounds (MVOCs) produced by moulds on various materials. International Journal of Hygiene and Environmental Health 204: 111-121.

Fischer G, Dott W. 2003. Relevance of airborne fungi and their secondary metabolites for environmental, occupational and indoor hygiene. Archives of Microbiology 179: 75-82.

Franceschi VR, Krokene P, Christiansen E, Krekling T. 2005. Anatomical and chemical defenses of conifer bark against bark beetles and other pests. New Phytologist 167: 353376.

Gao P, Martin J. 2002. Volatile metabolites produced by three strains of Stachybotrys chartarum cultivated on rice and gypsum board. Applied Occupational and Environment Hygiene 17: 430-436.

Gao P, Korley F, Martin J. 2002. Determination of unique volatile metabolites produced by five Aspergillus species commonly found in problem buildings. American Industrial Hygiene Association Journal 63: 135-140.

Gao Y, Jin YJ, Li HD, Chen HJ. 2005. Volatile organic compounds and their roles in bacteriostasis in five conifer species. Journal of Integrative Plant Biology 47: 499-507.

Gardner JW, Craven M, Dow C, Hines EL. 1998. The prediction of bacteria type and culture growth phase by an electronic nose with a multilayer perception network. Measurement Science and Technology 9: 120-127.

Garneau FX, Riedl B, Hobbs S, Pichette A, Gagnon H. 2004. Anwendung einer elektronischen Geruchs-Sonde für die schnelle Unterscheidung des Splint- und Kernholzes von ostkanadischer Fichte, Tanne und Kiefer. The use of sensor array technology for rapid differentiation of the sapwood and heartwood of Eastern Canadian spruce, fir and pine. Holz als Roh- und Werkstoff 62: 470-473. 
Gil GC, Mitchell RJ, Chang ST, Gu MB. 2000. A biosensor for the detection of gas toxicity using a recombinant bioluminiscent bacterium. Biosensors \& Bioelectronics 15: 23-30.

Guenther AB, Zimmerman PR, Harley PC, Monson RK, Fall R. 1993. Isoprene and monoterpene emission rate variability: model evaluations and sensitivity analyses. Journal of Geophysical Research 98: 609-617.

Guenther AB, Hewitt C, Erickson D, Fall R, Geron C, Graedel T, Harley P, Klinger PL, Lerdau M, McKay W, Pierce T, Scholes B, Steinbrecher R, Tallamraju R, Taylor J, Zimmerman P. 1995. A global model of natural volatile organic compound emissions. Journal of Geophysical Research 100: 8873-8892.

Hakola H, Laurila T, Lindfors V, Hellén H, Gaman A, Rinne J. 2001. Variation of the VOC emission rates of birch species during the growing season. Boreal Environment Research 6: 237-249.

Harborne JB, Turner BL. 1984. Plant chemosystematics. Academic Press, London, UK.

Harley PC, Monson RK, Lerdau MT. 1999. Ecological and evolutionary aspects of isoprene emission from plants. Oecologia 118: 109-123.

Harmon ME. 1986. Ecology of coarse woody debris in temperate ecosystems. Advances in Ecological Research 15: 133-302.

Harrington TC, McNew D, Steimel J, Hofstra D, Farrell R. 2001. Phylogeny and taxonomy of the Ophiostoma piceae complex and the Dutch elm disease fungi. Mycologia 93: 111-136.

Hatanaka A. 1993. The biogeneration of green odour by green leaves. Phytochemistry 34: 1201-1218.

Hayward S, Tani A, Owen SM, Hewitt CN. 2004. Online analysis of volatile organic compound emissions from Sitka spruce (Picea sitchensis). Tree Physiology 24: 721-728.

Hendry J, Boddy L, Lonsdale D. 2002. Abiotic variables effect differential expression of latent infections in beech (Fagus sylvatica). New Phytologist 155: 449-460.

Hobbs S, Garneau F, Riedl B. 2000. Distinguishing spruce, fir and pine woods fort he pulp and paper industry. Cyrano Sciences Application Note. Cyrano Sciences, Pasadena, CA.

Hoegger PJ, Majcherczyk A, Dwivedi RC, Kilaru S, Svobodová K, Kües U. 2007. Enzyme in wood degradation. In: Kües $\mathrm{U}$ (Ed). Wood production, wood technology and biotechnological impacts. Universitätsverlag Göttingen, Göttingen. pp. 383-432.

Holighaus G, Schütz S. 2006. Odours of wood decay as semiochemicals for Xyloterus domesticus, L. (Col., Scolytidae). Mitteilungen der Deutschen Gesellschaft für allgemeine und angewandte Entomologie 15: 161-165.

Holmberg M. 1997. Data evaluation for an electronic nose. PhD thesis, Linköping University, Linköping, Sweden.

Holopainen JK. 2004. Multiple functions of inducible plant volatiles. Trends in Plant Science 9: 529-533.

Huber DPW, Borden JH. 2001. Protection of lodge pole pines from mass attack by mountain pine beetle, Dendroctonus ponderosae, with nonhost angiosperm volatiles and verbenone. Entomologia Experimentalis et Applicata 99: 131-141.

Hudgins JW, Christiansen E, Franceschi VR. 2004. Induction of anatomically based defense responses in stems of diverse conifers by methyl jasmonate: A phylogenetic perspective. Tree Physiology 24: 251-264.

Humphris SN, Wheatley ER, Bruce A. 2001. The effects of specific volatile organic compounds produced by Trichoderma spp. on the growth of wood decay basidiomycetes. Holzforschung 55: 233-237. 
Hüttermann A, Metzger JO. 2007. Carbon dioxide, forests and the Kyoto process. In: Kües U (Ed). Wood production, wood technology and biotechnological impacts. Universitätsverlag Göttingen, Göttingen. pp. 85-98.

Jacobs K, Wingfield MJ. 2001. Leptographium species: tree pathogens, insect associates, and agents of blue-stain. APS Press, St. Paul, Minnesota, USA.

Jentoft NA, Stray H. 2002. Stack emission monitoring - on-line capillary gas chromatography. In: Tagungsband 2. Fachtagung Umweltschutz in der Holz- und Werkstoffindustrie, 21. und 22. März 2002, Göttingen. Georg-August-Universität Göttingen, Institut für Holzbiologie und Holztechnologie, Lehrbereich Holzchemie und Holztechnologie, Göttingen, Germany. pp. 147-151.

Johansson I. 1999. The role of volatile organic compounds in the assessment of indoor air quality. PhD thesis, Royal Institute of Technology, Stockholm, Sweden.

Johne B, Füldner K, Weißbecker B, Schütz S. 2003. Kopplung der phänologischen Entwicklung der Rosskastanie (Aesculus hippocastnum, L.) mit Lebenszyklus und Verhalten der Kastanienminermotte (Cameraria obridella, Deschka \& Dimic) (Lepidoptera: Gracillariidae). Nachrichtenblatt des deutschen Pflanzenschutzdienstes 55: 213-220.

Johne B, Sprauer S, Weißbecker B, Schütz S. 2006a. The influence of flower odour compounds on the oviposition behaviour of the horse chestnut leafminer (Cameraria obridella). Mitteilungen der Deutschen Gesellschaft für allgemeine und angewandte Entomologie 15: 137-140.

Johne B, Weißbecker B, Schütz S. 2006b. Volatile emissions from Aesculus hippocastanum induced by mining of various larval stages of Cameraria obridella influence the oviposition behaviour of the moth. Journal of Chemical Ecology 32: 2303-2319.

Jonsell M, Nordlander G. 2004. Host selection patterns in insects breeding in bracket fungi. Ecological Entomology 29: 697-705.

Kafkas E, Cabaroglu T, Selli S, Bozdoğan A, Kürkçüoğlu M, Paydaş S, Başer KH. 2006. Identification of volatile aroma compounds of strawberry wine using solid-phase microextraction techniques coupled with gas chromatography-mass spectrometry. Flavour and Fragrance Journal 21: 68-71.

Kalemba D, Kunicka A. 2003. Antibacterial and antifungal properties of essential oils. Current Medicinal Chemistry 10: 813-829.

Keeling CI, Bohlmann J. 2006. Genes, enzymes and chemicals of terpenoid diversity in the constitutive and induced defence of conifers against insects and pathogens. New Phytologist 170: 657-675.

Keshri G, Magan N, Voysey P. 1998. Use of an electronic nose for the early detection and differentiation of spoilage fungi. Letter of Applied Microbiology 27: 261-264.

Keshri G, Challen M, Elliott T, Magan N. 2003. Differentiation of Agaricus species and other homobasidiomycetes based on volatile production patterns using an electronic nose system. Mycological Research 5: 609-613.

Kesselmeier J, Staudt M. 1999. Biogenic volatile organic compounds (VOC): an overview on emission, physiology and ecology. Journal of Atmospheric Chemistry 33: 23-88.

Kirisits T. 2004. Fungal associates of European bark beetles with special emphasis on the Omphiostomatoid fungi. In: Lieutier F, Day KR, Battisti A, Grégoire J-C. (Eds.) Bark and wood boring insects in living trees in Europe: a synthesis. Kluwer Academic Publisher, Boston, MA. pp. 181- 235.

Klepzig KD, Smalley EB, Raffa KF. 1996. Combined chemical defences against an insectfungal complex. Journal of Chemical Ecology 22: 1367-1388. 
Kloeser L, Kües U, Schöpper C, Hosseinkhani H, Schütz S, Dantz S, Malik I, Vos H, Bartholme M, Müller C, Polle A, Kharazipour A. 2007. Panel boards and conventional adhesives. In: Kües U (Ed). Wood production, wood technology and biotechnological impacts. Universitätsverlag Göttingen, Göttingen. pp. 297-346.

Kolařík M, Kubátová A, Čepička I, Pažoutová S, Šrůtka P. 2005. A complex of three new white-spored, sympatric, and host range limited Geosmithia species. Mycological Research 109: 1323-1336.

Korpi A, Pasanen A L, Viitanen H. 1998. Volatile metabolites of Serpula lacrymans, Coniophora puteana, Poria placenta, Stachybotrys chartarum and Chaetomium globosum. Building and Environment 34: 205-211.

Kües U. 2000. Life history and development processes in the basidiomycete Coprinus cinereus. Microbiology and Molecular Biology Reviews 64: 316-353.

Kües U, Navarro-Gonzaléz M, Srivilai P, Chaisaena W, Velagapudi R. 2007. Mushroom biology and genetics. In: Kües U (Ed). Wood production, wood technology and biotechnological impacts. Universitätsverlag Göttingen, Göttingen. pp. 587-608.

Lee J-G, Lee C-G, Kwag J-J, Buglass AJ, Lee G-H. 2005. Determination of optimum conditions for the analysis of volatile components in pine needles by double-shot pyrolysis-gas chromatography-mass spectrometry. Journal of Chromatography A 1089: 227-234.

Lerdau M, Guenthe A, Monson R. 1997. Plant production and emission of volatile organic compounds: plant-produced hydrocarbons influence not only the plant itself but the atmosphere a well. BioScience 47: 373-383.

Lieutier F. 2004. Host resistance to bark beetles and its variations. In: Lieutier F, Day KR, Battisti A, Grégoire J-C. (Eds) Bark and wood boring insects in living trees in Europe: a synthesis. Kluwer Academic Publisher, Boston, MA, pp. 135-180.

Litvak ME, Monson RK. 1998. Patterns of induced and constitutive monoterpene production in conifer needles in relation to insect herbivory. Oecologia 114: 531-540.

Loreto F, Barta C, Brilli F, Nogues I. 2006. On the induction of volatile organic compound emissions by plants as consequence of wounding or fluctuations of light and temperature. Plant Cell and Environment 29: 1820-1828.

Mai C, Militz H. 2007. Chemical wood protection. In: Kües U (Ed). Wood production, wood technology and biotechnological impacts. Universitätsverlag Göttingen, Göttingen. pp. 259-272.

Majcherczyk A, Hüttermann A. Wood as a renewable energy source. In: Kües U (Ed). Wood production, wood technology and biotechnological impacts. Universitätsverlag Göttingen, Göttingen. pp. 99-116.

Manker D. 2005. Fungus fumes could replace methyl bromide. Industrial Bioprocessing 27: 56.

Manninen AM, Pasanen P, Holopainen JK. 2002. Comparing the VOC emissions between airdries and heat treated Scots pine wood. Atmospheric Environment 36: 1763-1768.

Marutzky R, Roffael E. 1977. Über die Abspaltung von Formaldehyd bei der thermischen Behandlung von Holzspänen. Holzforschung 31: 8-12.

Matsui K. 2006. Green leaf volatiles: hydroperoxide lyase pathway of oxylipin metabolism. Current Opinion in Plant Biology 9: 274-280.

Mau JL, Chyau CC, Li JY, Tseng YH. 1997. Flavor compounds in straw mushrooms Volvariella volvacea harvested at different stages of maturity. Journal of Agricultural and Food Chemistry 45: 4726-4729. 
Mauriello G, Marino R, D’Auria M, Cerone G, Rana LG. 2004. Determination of volatile organic compounds from truffles via SPME-GC-MS. Journal of Chromatographic Science 42: 299-305.

Menotta M, Gioacchini MA, Amicucci A, Buffalini M, Sisti D, Stocchi V. 2004. Headspace solid-phase microextraction with gas chromatography and mass spectrometry in the investigation of volatile organic compounds in an ectomycorrhizae synthesis system. Rapid Communications in Mass Spectrometry 18: 206-210.

Meyer RL, Larsen LH, Revsbech NP. 2002. Microscale biosensor for measurement of volatile fatty acids in anoxic environments. Applied Environmental Microbiology 68: 1204-1210.

Mithöfer A, Wanner G, Boland W. 2005. Effects of feeding Spodoptera littoralis on lima bean leaves. II. Continuous mechanical wounding resembling insect feeding is sufficient to elicit herbivory-related volatile emission. Plant Physiology 137: 1160-1168.

Mølhave L, Clausen G, Berglund B, De Ceaurriz J, Kettrup A, Lindvall T, Maroni M, Pickering AC, Risse U, Rothweiler H, Seifert B, Younes M. 1997. Total Volatile Organic Compounds (TVOC) in indoor air quality investigations. Indoor Air 7: 225-240.

Moore JC, Berlow EL, Coleman DC, De Suiter PC, Dong Q, Hastings A, Johnson NC, McCann KS, Melville K, Morin PJ, Nadelhoffer K, Rosemond AD, Post DM, Sabo JL, Scow KM, Vanni MJ, Wall DH. 2004. Detritus, trophic dynamics and biodiversity. Ecology Letters 7: 584-600.

Moukhtar S, Bessagnet B, Rouil L, Simon V. 2005. Monoterpene emissions from beech (Fagus sylvatica) in a French forest and impact on secondary pollutants formation at regional scale. Atmospheric Environment 39: 3535-3547.

Mueller UG, Gerardo NM, Aanen DK, Six DL, Schultz TR. 2005. The evolution of agriculture in insects. Annual Review of Ecology, Evolution and Systematics 36: 563-595.

Müller C, Kües U, Schöpper C, Kharazipour A. 2007. Natural binders. In: Kües U (Ed). Wood production, wood technology and biotechnological impacts. Universitätsverlag Göttingen, Göttingen. pp. 347-382.

Mwinyihija M, Strachan NJC, Meharg A, Killham K. 2005. Biosensor based toxicity dissection of tannery and associated environmental samples. Journal of the American Leather Chemists Association 100: 481-490.

Nilsson A, Khilström E, Lagesson V, Wessén B, Szponar B, Larsson L, Tagesson C. 2004. Microorganisms and volatile organic compounds in airborne dust from damp residences. Indoor Air 14: 74-82.

Otw ell LP, Hittmeier ME, Hooda U, Yan H, Su W, Banerjee S. 2000. HAPs release from wood drying. Environmental Science and Technology 34: 2280-2283.

Overton VS. 1994. Determination of volatile organic compounds in mushrooms. The Mass Spec Source 18: 4-7.

Owen S, Boissard C, Street RA, Duckham SC, Csiky O, Hewitt CN. 1997. Screening of 18 mediterranean plant species for volatile organic compound emissions. Atmospheric Environment 31: 101-117.

Owen SM, Peñuelas J. 2005. Opportunistic emissions of volatile isoprenoids. Trends in Plant Science 10: 420-426.

Paczkovska M, Füldner K, Weissteiner S, Benival R, Polle A, Schütz S. 2006. The role of the poplar's volatiles for the butterflies of the forest margin. Mitteilungen der Deutschen Gesellschaft für allgemeine und angewandte Entomologie 15: 213-217.

Paine TD, Raffa KF, Harrington TC. 1997. Interactions among scolytid bark beetles, their associated fungi, and live host conifers. Annual Review of Entomology 42: 179-206. 
Paiva NL. 2000. An introduction to the biosynthesis of chemicals used in plant-microbe communication. Journal of Plant Growth Regulation 19: 131-143.

Pasanen AL. 1992. Occurrence and moisture requirements of microbial growth in buildings. International Biodeterioration \& Biodegradation 30: 273-283.

Pasteels JM, Rowellrahier M. 1992. The chemical ecology of herbivory on willows. Proceedings of the Royal Society of Edinburgh Section B - Biological Sciences 98: 63-73.

Pearce TC, Schiffman SS, Nagle H, Gardner JW. (Eds) 2003. Handbook of Machine Olfaction, Wiley-VCH Verlag, Weinheim, Germany.

Pemmasani JK, Polle A, Bolte A, Kües U. 2007. Biological monitoring of pollution in forests and of pollution caused by wood utilisation. In: Kües U (Ed). Wood production, wood technology and biotechnological impacts. Universitätsverlag Göttingen, Göttingen. pp. 229-256.

Peñuelas J, Llusià J. 2001. The complexity of factors driving volatile organic compound emissions by plants. Biologia Plantarum 44: 481-487.

Peñuelas J, Llusià J. 2004. Plant VOC emissions: making use of the unavoidable. Trends in Ecology \& Evolution 19: 402-404.

Petterson E, Boland W. 2003. Potential parasitoid attractants, volatile composition throughout a bark beetle attack. Chemecology 13: 27-37.

Phillips MA, Croteau RB. 1999. Resin-based defenses in conifers. Trends in Plant Science 4: 184-190.

Pichette A, Garneau F-X, Jaen F-I, Riedl B, Girard M. 1998. Chemical differences between the wood extracts of jack pine (Pinus banksiana), black spruce (Picea mariana) and balsam fir (Abies balsamea) from eastern Canada. Journal of Wood Chemistry Technology 18: 427.

Pio CA, Silva PA, Cerqueira MA, Nunes TV. 2005. Diurnal and seasonal emissions of volatile organic compounds from cork oak (Quercus suber) trees. Atmospheric Environment 39: $1817-1827$.

Pinheiro C, Rodrigues CM, Schäfer T, Crespo JG. 2001. Monitoring the aroma production during wine-must fermentation with an electronic nose. Biotechnology and Bioengineering 77: 632-636.

Podola B, Nowack ECM, Melkonian M. 2004. The use of multiple-strain algal sensor chips for the detection and identification of volatile organic compounds. Biosensors \& Bioelectronics 19 1253-1260.

Portnoy JM, Kwak K, Dowling P, Van Osdol T, Barnes C. 2005. Health effects of indoor fungi. Annals of Allergy, Asthma and Immunology 94: 313-320.

Porto D, Cordaro F, Marcassa N. 2006. Effects of carbohydrate and noncarbohydrate sweeteners on the orange spirit volatile compounds. Food Science and Technology 39: 159-165.

Priest D. 2002. Natural antimicrobials for personal care. Chimica Oggi 20: 43-46.

Quiroz A, Fuentes-Contrera E, Ramírez CC, Russell GB, Niemeyer HM. 1999. Host-plant chemicals and distribution of Neuquenaphis on Nothofagus. Journal of Chemical Ecology 25: 1043-1054.

Reddy GVP, Fettköther R, Noldt U, Dettner K. 2005a. Capture of female Hylotrupes bajulus as influenced by trap type and pheromone blend. Journal of Chemical Ecology 31: 21692177. 
Reddy GVP, Fettköther R, Noldt U, Dettner K. 2005b. Enhancement of attraction and trap catches of the old-house borer, Hylotrupes bajulus (Coleoptera: Cerambycidae), by combination of male sex pheromone and monoterpenes. Pest Management Science 61: 699-704.

Revsbech NP. 2005. Analysis of microbial communities with electrochemical microsensors and microscale biosensors. Methods in Enzymology 397: 147-166.

Risholm-Sundman M. 2002. VOC-emission from Wood Based Panels. In: Tagungsband 2. Fachtagung Umweltschutz in der Holz- und Werkstoffindustrie, 21. und 22. März 2002, Göttingen. Georg-August-Universität Göttingen, Institut für Holzbiologie und Holztechnologie, Lehrbereich Holzchemie und Holztechnologie, Göttingen, Germany. pp. 152-161.

Risholm-Sundman M, Lundgren M, Vestin E, Herder P. 1998. Emission of acetic acid and other volatile organic compounds from different species of solid wood. Holz als Roh- und Werkstoff 56: 125-129.

Rosatto SS, Freire RS, Durán N. 2001. Amperometric biosensors for phenolic compounds determination in environmentally interesting samples. Quimica Nova 24: 77-86.

Rösecke J, Pietsch M, König WA. 2000. Volatile constitutents of wood-rotting basidiomycetes. Phytochemistry 54: 747-750.

Rotariu L, Bala C, Magearu V. 2004. New potentiometric microbial biosensor for ethanol determination in alcoholic beverages. Analytica Chimica Acta 513: 119-123.

Ruther J. 2000. Retention index database for identification of general green leaf volatiles in plants by coupled capillary gas chromatography-mass spectrometry. Journal of Chromatography A 890: 313-319.

Rühl M, Kilaru S, Hoegger PJ, Kharazipour A, Kües U. 2007. Production of laccase and other enzymes for the wood industry. In: Kües $U(E d)$. Wood production, wood technology and biotechnological impacts. Universitätsverlag Göttingen, Göttingen. pp. 469-508.

Schäfer M, Roffael E. 2000. On the formaldehyde release of wood. Holz als Roh- und Werkstoff 58: 259-264.

Schiffman SS, Wyrick DW, Guitierrez-Osuna R, Nagle HT. 2000. Effectiveness of an electronic nose for monitoring bacterial and fungal growth. In: Gardner JW, Persaud KC. (Eds) Electronic Noses and Olfaction 2000. Institute of Physics Publishing, Bristol, UK. pp. 173-180.

Schiffman SS, Bennett JL, Raymer JH. 2001. Quantification of odours and odourants from swine operations in North Carolina. Agricultural and Forest Meteorology 108: 213-240.

Schleibinger H, Laußmann D, Brattig C, Mangler M, Eis D, Rüden H. 2005. Emission patterns and emission rates of MVOC and the possibility for predicting hidden mold damage? Indoor Air 15: 98-104.

Schlyter F. 2004. Semiochemicals in the life of bark feeding weevils. In: Lieutier F, Day KR, Battisti A, Grégoire J-C. (Eds) Bark and wood boring insects in living trees in Europe: a synthesis. Kluwer Academic Publisher, Boston, MA, pp. 351-364.

Schnürer J, Olsson J, Börjesson T. 2002. Fungal volatiles as indicators of food and foods spoilage. Fungal Genetics and Biology 27: 209-217.

Schroth P, Schöning MJ, Kordos P, Lüth H, Schütz S, Weißbecker B, Hummel HE. 1999. Insect-based BioFETs with improved signal characteristics. Biosensors \& Bioelectronics 14: 303-308. 
Schütz S. 2001. Der Einfluß verletzungsinduzierter Emissionen der Kartoffelpflanze (S. tuberosum) auf die geruchliche Wirtspflanzenfindung und -auswahl durch den Kartoffelkäfer (L. decemlineata) - Ein Biosensor für die Diagnose von Pflanzenschäden. Wissenschaftlicher Fachverlag Dr. Fleck, Wetzlar, Germany.

Schütz S. 2004. Fire recognition on the basis of insect olfactory systems. Abstracts of the XXII International Conference on Entomology, Brisbane, Australia, 15-21 August 2004. p. 314.

Schütz S, Weißbecker B. 2003. Mechanismen duftvermittelter Pflanze-Insekt Interaktionen: Vom Pflanzenstress zum Insektenfraß. Nova Acta Leopoldina 328: 215-235.

Schütz S, Weißbecker B, Klein A, Hummel HE. 1997. Host plant selection of the Colorado potato beetle as influenced by damage induced volatiles of the potato plant. Naturwissenschaften 84: 212-217.

Schütz S, Weissbecker B, Hummel HE, Apel K-H, Schmitz H, Bleckmann H. 1999a. Insect antennae as a smoke detector. Nature 398: 298-299.

Schütz S, Weißbecker B, Koch UT, Hummel HE. 1999b. Detection of volatiles released by diseased potato tubers using a biosensor on the basis of intact insect antennae. Biosensors and Bioelectronics 14: 221-228.

Schütz S, Weißbecker B, Schroth P, Schöning MJ. 2001. Linkage of inanimate structures to biological systems - Smart materials in biological micro- and nanosystems. In: Hoffmann $\mathrm{KH}$. (Ed) Lecture notes in computational science and engineering. Springer-Verlag, Heidelberg-New York. pp. 215-221.

Schütz S, Weißbecker B, Apel K-H, Wenk M. 2004. Duftstoffe als Marker für die Befallsdisposition von Kiefern durch den Blauen Kiefernprachtkäfer Phaenops cyanea F. (Col., Buprestidae). Mitteilungen der Deutschen Gesellschaft für allgemeine und angewandte Entomologie 14: 301-306.

Scotter MJ, Langford SV, Wilson FP, McEwan JM, Chambers TS. 2005. Real-time detection of common microbial volatile organic compounds from medically important fungi by Selected Ion Flow Tube-Mass Spectrometry (SIFT-MS). Journal of Microbiological Methods 63: 127-134.

Seybold SJ, Huber DPW, Lee JC, Graves AD, Bohlmann J. 2006. Pine monoterpenes and pine bark beetles: A marriage of convenience for defense and chemical communication. Phytochemistry Reviews 5: 143-178.

Sharkey TD, Singsaas EL. 1995. Why plants emit isoprene. Nature 374: 769.

Sjödin K, Persson M, Fäldt J, Ekberg I, Borg-Karlson AK. 2000. Occurrence and correlations of monoterpene hydrocarbon enantiomers in Pinus sylvestris and Picea abies. Journal of Chemical Ecology 26: 1701-1720.

Stadler M, Ju YM, Rogers JD. 2004. Chemotaxonomy of Entonaema, Rhopalostroma and other Xylariaceae. Mycological Research 108: 239-256.

Staudt M, Joffre R, Rambal S, Kesselmeier J. 2001. Effect of elevated $\mathrm{CO}_{2}$ on monoterpene emission of young Quercus ilex trees and its relation to structural and ecophysiological parameters. Tree Physiology 21: 437-445.

Staudt M, Joffre R, Rambal S. 2003. How growth conditions affect the capacity of Quercus ilex leaves to emit monoterpenes. New Phytologist 158: 61-73.

Sundin B, Roffael E. 1992. Determination of emissions from wood-based panels using the flask method. Holz als Roh- und Werkstoff 50: 383-386.

Thakeow P, Weißbecker B, Schütz S. 2006. Volatile organic compounds emitted from fungalrotting beech (Fagus sylvatica). Mitteilungen der Deutschen Gesellschaft für allgemeine und angewandte Entomologie 15: 157-160. 
Thomsen IM, Koch J. 1999. Somatic compatibility in Amylostereum aerolatum and A. chailleti as a consequence of symbiosis with syricid woodwasps. Mycological Research 103: 817-823.

Tjeerdsma BF, Boonstra M, Pizzi A, Tekely P, Militz H. 1998. Characterisation of thermally modified wood: molecular reasons for wood performance improvement. Holz als Rohund Werkstoff 56: 149-153.

Tollsten L, Müller PM. 1996. Volatile organic compounds emitted from beech leaves. Phytochemistry 43: 759-762.

Trapp S, Croteau R. 2001. Defensive resin biosynthesis in conifers. Annual Review of Plant Physiology and Plant Molecular Biology 52: 689-724.

Tscharntke T, Thiessen S, Dolch R, Boland W. 2001. Herbivory, induced resistance and interplant signal transfer in Alnus glutinosa. Biochemical Systematics and Ecology 29: 10251047.

van der Heijden MGA, Sanders IR. (Eds) 2002. Mycorrhizal ecology. Ecological studies, analysis and synthesis, Vol. 157. Springer, Berlin, Germany.

van Doorn WG, Woltering EJ. 2005. Many ways to exit? Cell death categories in plants. Trends in Plant Science 10: 117-122.

Vega FE, Blackwell M. (Eds) (2005). Insect-fungal associations: ecology and evolution. Oxford University Press, Oxford, UK.

Venkateshwarlu G, Chandravadana MV, Tewari RP. 1999. Volatile flavour components of some edible mushrooms (Basidiomycetes). Flavour and Fragrance Journal 14: 191-194.

Visser JH. 1979. Electroantennogram responses of the Colorado beetle Leptinotarsa decemlineata to plant volatiles. Entomologia Experimentalis et Applicata 25: 86-97.

Wang JC, Wang HH. 2002. Fermentation products and carbon balance of spoilage Bacillus cereus. Journal of Food and Drug Analysis 10: 64-68.

Wang S-Y, Wu C-L, Chu F-H, Chien S-C, Kuo Y-H, Shyur L-F, Chang S-T. 2005. Chemical composition and antifungal activity of essential oil isolated from Chamaecyparis formosensis Matsum. wood. Holzforschung 59: 295-299.

Watanabe H, Tokuda G. 2001. Animal cellulases. Cellular and Molecular Life Sciences 58: 1167-1178.

Weissbecker B, Holighaus G, Schütz S. 2004. Gas chromatography with mass spectrometric and electroantennographic detection: analysis of wood odour by direct coupling of insect olfaction and mass spectrometry. Journal of Chromatography A 1056: 209-216.

Wheatley R, Hackett C, Bruce A, Kundzewicz A. 1997. Effect of substrate composition on production of volatile organic compounds from Trichoderma spp. inhibitory to wood decay fungi. International Biodeterioration \& Biodegradation 39: 199-205.

Wilding N, Collins NM. Hammond PM, Webber JF. (Eds) 1989. Insect-fungus interactions. Symposium of the Royal Entomological Society of London 14. Academic Press, London, $\mathrm{UK}$.

Wilkins K, Larsen K, Simkus M. 2003. Volatile metabolites from indoor molds grown on media containing wood constituents. Environmental Science and Pollution Research 10: 206208.

Wollenberger U, Rennenberg R, Bier TF, Scheller FW. (Eds) 2000. Biosensors. Wiley VCH Weinheim, Germany.

Wu S, Krings U, Zorn H, Berger GR. 2005a. Volatile compounds from the fruiting bodies of beefsteak fungus Fistulina hepatica (Schaeffer: Fr.). Food Chemistry 92: 221-226. 
Wu S, Zorn H, Krings U, Berger G. 2005b. Characteristic volatiles from young and aged fruiting bodies of wild Polyporus sulfureus (Bull.:Fr.). Journal of Agricultural Food Chemistry 53: 4524-4528.

Zeneli G, Krokene P, Christiansen E, Krekling T, Gershenzon J. 2006. Methyl jasmonate treatment of mature Norway spruce (Picea abies) trees increases the accumulation of terpenoid resin components and protects against infection by Ceratocystis polonica, a bark beetle-associated fungus. Tree Physiology 26: 977-988.

Zawirska-Wojtasiak R. 2004. Optic purity of (R)-(2)-1-octen-3-ol in the aroma of various species of edible mushrooms. Food Chemistry 86: 113-118.

Zeppa S, Gioacchini MA, Guidi C, Cuescini M, Pierleni R, Zambonelli A, Stocchi V. 2004. Determination of specific volatile organic compounds synthesised during Tuber borchii fruit body development by solid-phase microextraction and gas chromatography/mass spectrometry. Rapid Communications in Mass Spectrometry 18, 199-205.

Zhang Q-H, Schlyter F. 2004. Olfactory recognition and behavioural avoidance of angiosperm nonhost volatiles by conifer-inhabiting bark beetles. Agricultural and Forest Entomology 6:1-19.

Zini CA, Augusto F, Christensen E, Caramão EB, Pawliszyn J. 2002. SPME applied to the study of volatile organic compounds emitted by three species of Eucalyptus in situ. Journal of Agricultural and Food Chemistry 50: 7199-7205. 


\section{CHAPTER 3}

\section{Monitoring of Volatile Organic Compounds Released from Fungal-Infected Beech \\ (Fagus sylvatica)}

Some part of this chapter was published in:

Thakeow P, Weißbecker B, Schütz S. 2006. Volatile organic compounds emitted from fungal-rotting beech (Fagus sylvatica). Mitteilungen der Deutschen Gesellschaft für allgemeine und angewandte Entomologie 15: 157-160. 



\subsection{Abstract}

Three types of wood-rotting fungi, Trametes versicolor, Poria placenta and Gloeophyllum trabeum were inoculated on beech wood (Fagus sylvatica). These fungi were chosen because they are employed in standard procedures testing wood durability. Volatile organic compounds (VOCs) were sampled for twelve weeks after inoculation using solid phase microextraction (SPME) and were analysed by gas chromatography- mass spectrometry (GC-MS). Beech wood inoculated with those three different fungi released specific patterns of VOCs. The VOCs were identified and categorised into two groups: C5-C8 compounds and terpenoids. Compounds in the first group like 1-octen-3-ol, 3-octanone, and 3-octanol were common in all fungal infested samples. Additionally, some sesquiterpenes were species specific. $\alpha$ - and $\beta$-Barbatene were characteristic for T. versicolorinfected beech, protuillud-6-ene was characteristic for G. trabeum-infected beech, and daucene was characteristic for $P$. placenta-infected beech. Monitoring the VOCs released from fungal-infected wood could be a promising method for a fast and non-destructive screening of wood quality.

Keywords: wood decay, fungi, GC-MS, SPME, VOCs, Trametes versicolor, Poria placenta, Gloeophyllum trabeum 


\subsection{Introduction}

The major agents contributing to wood degradation are bacteria, fungi, insects, and marine borers (Robert and Morrell 1992; Eaton and Hale 1993). Wood degradation compromises important properties of wood. Therefore, wood quality has to be examined prior to use. Wood degrading fungi release enzymes reacting with the wood substrate, i.e., celluloses, hemicelluloses, and lignin. The degradation of wood substrate and the metabolism of the fungi yield different degradation products and metabolites. Some of these compounds can vaporise at room temperature as 'volatile organic compounds' (VOCs) and can indicate wood degrading activity of fungi. There have been approaches in different fields to perform quality assessment by monitoring VOCs. In food and beverage industry, VOCs are used for evaluation of wine (Begala et al. 2002) and cheese quality (Trihaas et al. 2005). In medicine, VOCs of human breath are used for diagnosis of diabetics (Deng et al. 2004) and halitosis (van den Velde et al. 2007). In addition, volatile metabolites were used as indicators for potential health effects because of indoor climate, commonly known as “sick-building syndrome" (Sunesson et al. 1995; Griffith et al. 2007). This study assesses if monitoring VOCs might become a promising method for non-destructive and fast evaluation of microbial activity on wood. For this purpose we investigated the VOCs released from beech wood samples (Fagus sylvatica) infected by different types of woodrotting fungi (Basidiomycetes), Trametes versicolor, Poria placenta, and Gloeophyllum trabeum during time course of infection using solid phase microextraction (SPME) technique.

\subsection{Materials and methods}

\subsubsection{Fungal culture preparations}

The cultures of three wood-rotting Basidiomycete fungi, T. versicolor (white rot, WR), G. trabeum (brown rot, BR) and P. placenta (BR) were kindly provided by Dr. Ulrich Junga, Department of Wood Biology and Wood Product, University of Göttingen. The untreated beech wood (Fagus sylvatica), approximately 100-year old from Ebergoetzen, North-East 
from Goettingen, Germany, was used in this experiment as a substrate. The sapwood was cut into approximately $1 \times 1 \times 1 \mathrm{~cm}^{3}$ cubelets, and 12 grams of those pieces were filled in an 60-ml septum-capped vial, soaked with 6-ml tap water and were consequently autoclaved for $20 \mathrm{~min}\left(121^{\circ} \mathrm{C}, 100 \mathrm{kPa}\right)$. Each of these samples was inoculated with $1 \mathrm{~cm}^{2}$ mycelium patch of T. versicolor, P. placenta or G. trabeum. The wetted and un-inoculated samples were kept as control samples throughout the whole experiment. The cultures were incubated in the darkness at $22^{\circ} \mathrm{C}$ and $70 \%$ relative humidity for 12 weeks.

\subsubsection{VOC sampling}

The sampling was carried out 1, 2, 3, 4, 8, and 12 weeks after inoculation at room temperature. VOCs released to headspace were sampled by solid phase microextraction (SPME), $85 \mu \mathrm{m}$ Carboxen ${ }^{\mathrm{TM}} /$ Polydimethylsiloxane (PDMS) StableFlex ${ }^{\mathrm{TM}}$ fibre type (Supelco, USA). Before sampling, the fibre was cleaned and sterilised by inserting to a $250^{\circ} \mathrm{C}$ injection port for $5 \mathrm{~min}$. For sampling the fibre housed inside the needle was pierced through a septum into the headspace of the vial and was exposed to adsorb the VOCs for $30 \mathrm{~min}$. After sampling the fibre was retracted into the needle and was afterwards directly inserted into the GC injection port and exposed for desorption and further analysis. The control samples were taken in parallel throughout the whole experiment.

In order to mimic the dynamically natural system and to monitor the fungal VOCs possibly released, the vials were manually shaken for inflicting small damages to the mycelium. The vials were sampled three hours after damage. Under natural conditions mycelium is frequently damaged by wind movement or insects. 


\subsubsection{VOC analysis using gas chromatography and mass spectrometry} (GC-MS)

A gas chromatograph (Agilent Technologies, model 6890N) connected with a mass spectrometer (Agilent Technologies, MS model 5973N) was used for VOCs analysis. The column was HP-5MS ( $30 \mathrm{~m} \times 0.25 \mathrm{~mm}$, i.d., $0.25 \mu \mathrm{m}$ film thickness), and helium was used as a carrier gas at $1.0 \mathrm{ml} \mathrm{min}{ }^{-1}$. The GC run was started with the initial temperature of $40^{\circ} \mathrm{C}$ and held for $1.5 \mathrm{~min}$, then heated up to $200^{\circ} \mathrm{C}$ with a heating rate of $6^{\circ} \mathrm{C} \mathrm{min}^{-1}$ and held at this temperature for $5 \mathrm{~min}$. MS was carried out with the mass scan range of 15-300 amu, $230^{\circ} \mathrm{C}$ source temperature and $\mathrm{EI}$ mode at $70 \mathrm{eV}$. Enhance chemstation version D00.00.38 (Agilent Technologies), the Mass Spectral Search library of the National Institute of Standards and Technology (NIST, Gaithersburg, USA), and the database of Massfinder version 3.0 software together with the library "Terpenoids and Related Constituents of Essential Oils" (Hochmuth, König, Joulain, Hamburg, Germany) were used for preliminary chromatogram interpretation. The analysis was confirmed by matching of mass spectra and retention times with those of authentic standards. 3-methyl1-butanol (98\%, Aldrich), 1-octen-3-ol (>98\%, Merck), 3-octanol (97\%, Merck), 3octanone (>96\%, VWR), 1-octene (98\%, Aldrich), $\alpha$-pinene (98\%, Sigma), 3-carene (>98.5\%, Fluka), $\alpha$-cubebene (97\%, Aldrich), (+)-longifolene (98\%, Aldrich), copaene $(>90 \%$, Fluka), chamigrene ( $\sim 90 \%$, Fluka).

\subsection{Results}

\subsubsection{Fungal cultures}

After one week of inoculation, the mycelium of T. versicolor, G. trabeum and P. placenta grew cover the upper part of wood stacks in vial. T. versicolor and P. placenta mycelium were white in colour, but $G$. trabeum was brownish yellow. On the third week after inoculation, all of 
them did not grow well. The mycelium started to grow well again in the eighth and twelfth weeks of inoculation.

\subsubsection{VOC analysis}

In this experiment we investigated the VOCs released from fungal-infected wood by inoculating beech either with T. versicolor, P. placenta or G. trabeum. The results are shown in Table 3-1 and Figures 3-1, for beech inoculated with T. versicolor, P. placenta and G. trabeum, respectively. During the whole course of experiments, these samples of rotted beech wood released individual patterns of VOCs. These volatiles included chemicals as alcohols (1methyl-3-butanol, 1-octen-3-ol and 3-octanol), ketones (3-octanone), aromatics (2,5-dimethyl furan), and sesquiterpenes (barbartenes and 6-protoilludene). Consequently, they were grouped into two categories, C5-C8 compounds and terpenoids. The monoterpenes $\alpha$ pinene and 3-carene were detected in beech wood control samples. Fungal infected samples without any mechanical damage to the mycelium released less volatiles than the damaged samples, especially in samples infected by the fungi T. versicolor and P. placenta, respectively. The compounds identified in these two beech sample sets infected with these two wood-rot fungi were 1-octen-3-ol, 3-octanone and 3-octanol, contributing a mushroom-like aroma to these two fungal- infected samples. In contrast, G. trabeuminfected beech, released many sesquiterpenes even without any damage on mycelium. The mixture of those volatiles resulted in pleasant and fruity odour. When the mycelium was ruptured, different compounds were released and the quantities increased, especially eightcarbon containing compounds (C8 compounds). Those, for example, were 1-octene, 3octanone, 3-octanol, and 1-octen-3-ol which are considered as typical compounds in mushrooms (Combet et al. 2006). In addition, many sesquiterpenes were released and some were typically released from each fungal species. For instance, $\alpha$ - and $\beta$-barbatene were individually found in beech infested with T. versicolor, 6-protoilludene was detected only from beech infested with $G$. trabeum, and daucene was specific to beech infested with P. placenta. 
Table 3-1 VOCs released from fungal-infected beech (Fagus sylvatica)

\begin{tabular}{|c|c|c|c|c|c|c|c|c|c|c|c|c|c|c|c|c|c|c|c|}
\hline \multirow[t]{2}{*}{ VOCs } & \multirow{2}{*}{$\begin{array}{c}\text { Retention } \\
\text { index } \\
\end{array}$} & \multicolumn{6}{|c|}{$\begin{array}{l}\text { Trametes } \\
\text { versicolor }\end{array}$} & \multicolumn{6}{|c|}{ Poria placenta } & \multicolumn{6}{|c|}{$\begin{array}{c}\text { Gloeophyllum } \\
\text { trabeum }\end{array}$} \\
\hline & & 1 & 2 & 3 & 4 & 8 & 12 & 1 & 2 & 3 & 4 & 8 & 12 & 1 & 2 & 3 & 4 & 8 & 12 \\
\hline \multicolumn{20}{|l|}{ Alcohols } \\
\hline 3-methyl-1-butanol ${ }^{\mathrm{S}}$ & 735 & + & + & + & + & + & & & & & & & & + & & & & & \\
\hline 1-octen-3-ol ${ }^{\mathrm{S}}$ & 980 & + & & & & & + & & & + & & + & + & + & & + & & & + \\
\hline 3-octanol ${ }^{\mathrm{S}}$ & 995 & + & + & & & & + & + & + & + & & + & & & & & & & \\
\hline \multicolumn{20}{|l|}{ Ketones } \\
\hline 3-octanone ${ }^{\mathrm{S}}$ & 987 & + & + & & + & & + & + & + & + & + & + & + & + & + & + & + & & + \\
\hline \multicolumn{20}{|l|}{ Ethers } \\
\hline 2,5-dimethyl furan ${ }^{\mathrm{L}}$ & 706 & & & & & + & & & & & & & & & & & & & \\
\hline \multicolumn{20}{|l|}{ Esters } \\
\hline propyl propanoate ${ }^{\mathrm{L}}$ & & + & & & & & & & & & & & & & & & & & \\
\hline $\begin{array}{l}\text { Hydrocarbons } \\
\text { 1-butyl methyl } \\
\text { cyclopropane/1-octene }\end{array}$ & 789 & + & & & & & + & & & & & & + & + & & & & & + \\
\hline \multicolumn{20}{|l|}{ Terpenoids } \\
\hline$\alpha$-pinene ${ }^{\mathrm{S}}$ & 935 & + & + & + & + & + & + & + & + & + & + & & & + & + & $T$ & + & + & \\
\hline 3 -carene ${ }^{\mathrm{S}}$ & 1011 & & & & & + & + & + & + & & & & & + & + & + & & & \\
\hline$\alpha$-cubebene ${ }^{\mathrm{s}}$ & 1359 & + & & & + & & + & & + & + & & & & & & & & & \\
\hline$\alpha$-longipinene ${ }^{\mathrm{L}}$ & 1365 & + & & & & & & & & & & & & & & & & & \\
\hline daucene $^{\mathrm{L}}$ & 1391 & & & & & & & + & + & + & + & & & & & & & & \\
\hline 6-protoilludene ${ }^{\mathrm{L}}$ & 1391 & & & & & & & & & & & & & + & + & + & + & + & + \\
\hline$\beta$-cubebene ${ }^{\mathrm{L}}$ & 1402 & + & & & & & + & & & + & & & & & & & & & \\
\hline sativene $^{\mathrm{L}}$ & 1411 & + & & & + & & + & & + & & + & & & + & & & & & \\
\hline$\beta$-longipinene ${ }^{\mathrm{L}}$ & 1417 & + & & & & & + & & & & & & & & & & & & \\
\hline
\end{tabular}


Table 3-1 continued

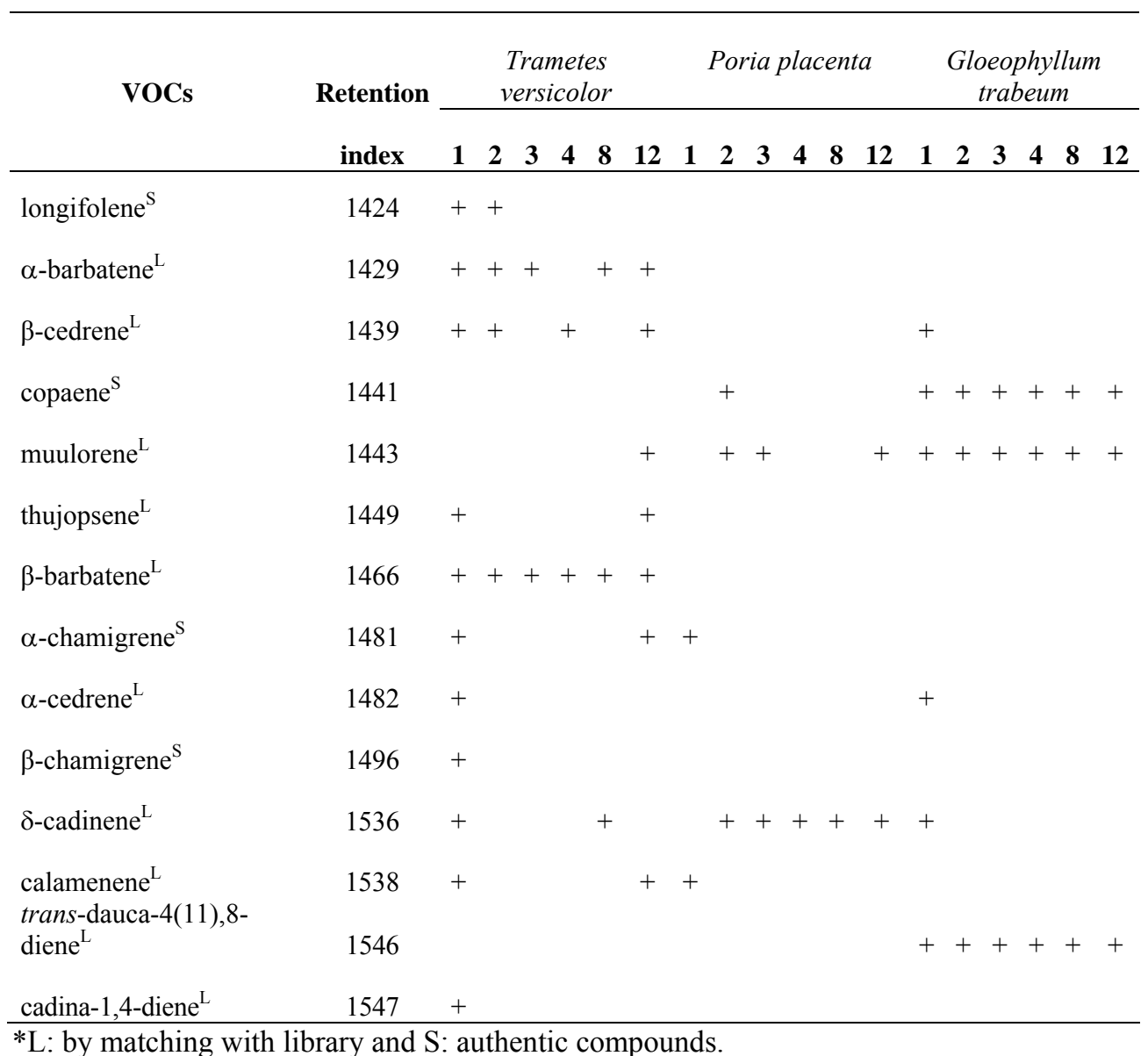

For the four consecutive weeks of experiment, the mycelium became weaken because of shaking and fewer VOCs were detected comparing to the VOCs released after the first week of inoculation. After they were let to develop (8- and 12-week of inoculations), they started to become fresh and more VOCs were released. During this time courses, the species specific sesquiterpenes were detected. 

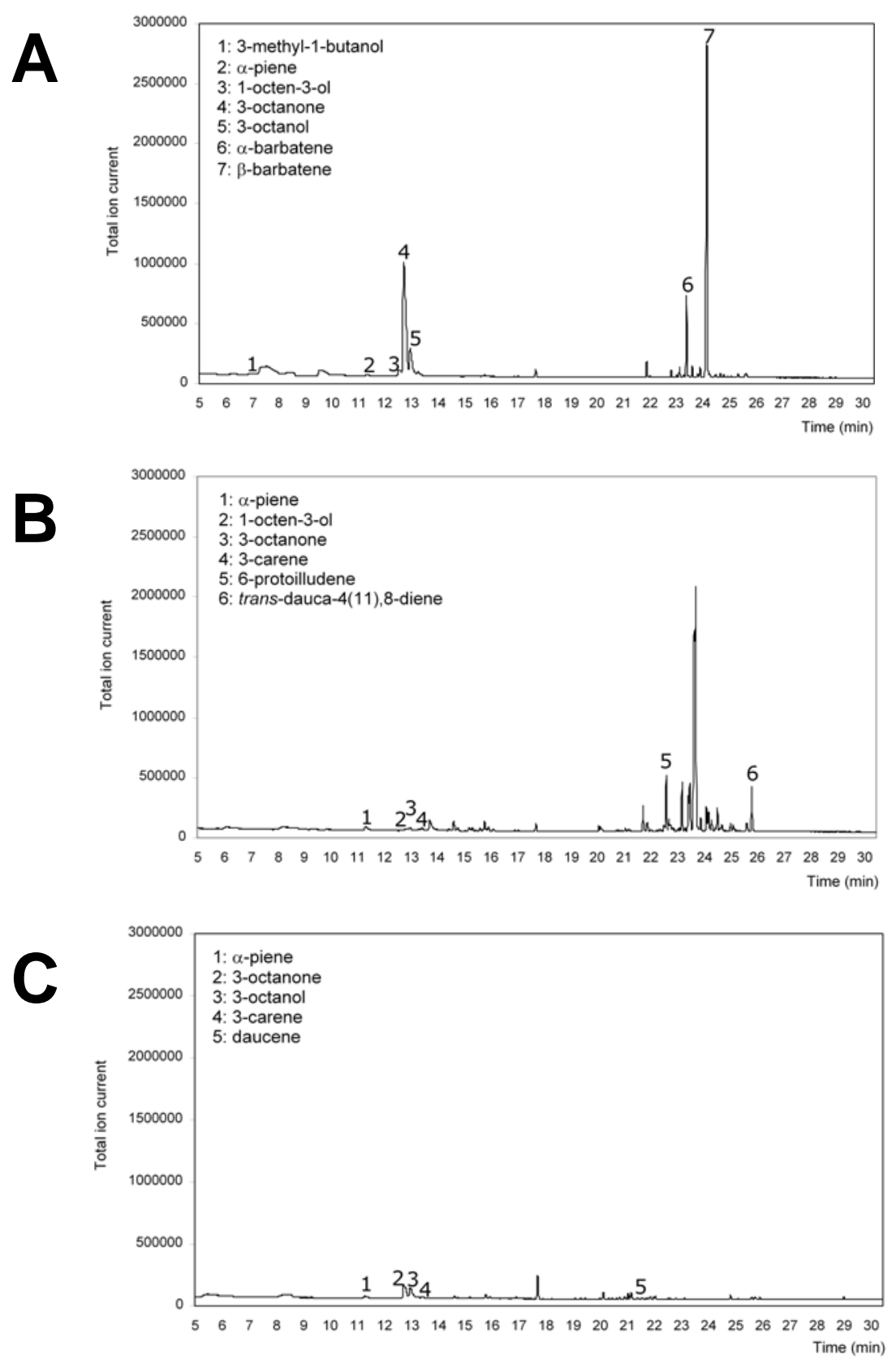

Figure 3-1 Examples of the chromatograms of fungal-infected beech wood (Fagus sylvatica) after 1-week inoculation. (A) T. versicolor, (B) G. trabeum, and (C) P. placenta. 
Table 3-1 showed VOCs released from beech infested with T. versicolor after the first week of infection. Those included typical fungal odours; 1-octene, 1-octen-3-ol, 3octanone and 3-octanol and other VOCs in aliphatic C5-C8 range, 3-methyl-1-butanol. The sesquiterpenes were mostly produced, which the distinguished ones released from this sample were $\alpha$ - and $\beta$-barbatene. It was observed that $\beta$-barbatene was released about four times in abundance higher than $\alpha$-barbatene, and it was detected over the whole course of experiment.

VOCs released from beech infested with $P$. placenta were less abundant and less numerous compounds, resulting in less complicated chromatograms than of T. versicolor and G. trabeum. The typical C8 compounds were dominant in the chromatograms and few sesquiterpenes were detected. The aliphatic of eight-carbon containing compounds were identified; those were 1-octen-3-ol, 1-octene, 3-octanone and 3-octanol. Two compounds from fungal odours of 3-octanone and 1-octanol were drastically released, therefore, this sample smelled like mushroom. The sesquiterpene daucene was not detected in the other tested fungi (Table 3-1).

Unlike to beech infested with the other brown rot fungus, beech inoculated with $G$. trabeum released (Table 3-1) sesquiterpenes being the main products. Three compounds in the aliphatic C5-C8 group were detected. Those were 1-octen-3-ol, 1-octene and 3octanone. In contrast to T. versicolor and P. placenta, sesquiterpenes were the most diverse group emitted from beech infected by this BR fungus. Some of the sesquiterpenes still need to be identified. Brasila-1,10-diene, italicene and 6-protoilludene were exclusively released from this sample. Amongst those chemicals, 6-protuilludene showed a remarkable high abundance. In contrast to the other two samples, the typical fungal odour of 1-octen3 -ol and 3-octanone was detected only in minute quantities. 


\subsection{Discussion}

Fungal deterioration causes changes of wood fibre and consequently a decline in physical properties of the mechanical wood properties. During wood degradation, volatile metabolites were released. Our experiments revealed that beech wood infected with three different fungi species released specific patterns of VOCs. Furthermore, course of infection and damage status of the mycelium alter the VOC patterns enhancing the amounts of $\mathrm{C} 8$ compounds and sesquiterpenes. The VOCs released by the fungi were products of their metabolisms which could be influenced by several factors, for example, different stages of life cycle (Zeppa et al. 2004; Schmidt and Kallow 2005; Thakeow et al. manuscript in preparation) and growth substrate (Bruce et al. 2004; Thakeow et al. 2007). C8 compounds, which are considered as typical fungal odours, were also present in these fungal-infected samples. Among those C8 volatiles, 1-octen-3-ol is mainly attributed to mushroom odour and it is proposed to be derived from linoleic acid (Tressl et al. 1982; Wurzenber and Grosch 1982; Combet et al. 2006). It was generally found in fungi. However, it is not yet clarified what the role of C8 compounds is. Plant volatiles derived from linoleic acid, like methyl jasmonate and 1-hexen-3-ol (green leave volatile) have been shown to play a crucial role in intra- and interspecific communication (Far 2001; León, et al. 2001; Matsui 2006). Lately it was found that in Penicillium paneum, 1-octen-3-ol plays an important role in conidia germination as a volatile self-inhibitor (Chitarra et al. 2004). In addition to the typical fungal odours, some sesquiterepenes contribute to the characteristic odour of each mushroom. Some were specifically released from each fungal-infected beech i.e., $\alpha$ - and $\beta$-barbatene, 6-protoilludene and daucene. These terpenes are specific products of secondary fungus metabolism (Abraham 2001; Keller et al. 2005). In general, sesquiterpenes are known to provide a wide range of useful antibiotic and pharmaceutical activities such as antifungal and antibacterial activities (Yu and Keller 2005). The volatiles released by microorganisms can have an antagonistic effect to other microorganisms for instance the growth of sapstain fungi can be inhibited by VOCs released from bacteria and yeast (Bruce et al. 2003, 2004). 
C8 compounds and species-specific sesquiterpenes can be used as marker compounds for fungal-infected wood. Additionally to these marker volatiles, 3-methyl-1-butan-1-ol was an optionally noticeable compound since it was consistently detected in T. versicolor infected beech samples. It was found that in pine rotted with Serpula lacrymans mycelium, 3methylbutanal was profoundly released from the dead mycelium (Ewen et al. 2004). This 3-methylbutanal could be the product of 3-methyl-1-butan-1-ol according to oxidation process of alcohol to aldehyde. These fungal compounds are well perceived by insects, for instance, 1-octen-3-ol is sensitively and selectively detected by the fungivorous insect Cis boleti (Thakeow et al. 2008) and $\beta$-barbatene from bracket fungi was proposed to be a marker compound used by beetles for host location (Fäldt et al. 1999).

There are several alternative approaches to identify wood degrading microorganisms. Fourier transform infrared spectrometry (FT-IR) can be used to identify T. versicolor and Schizophyllum commune degrading beech wood (Naumann et al. 2005). Polymerase chain reaction (PCR) (SooKyung et al. 2003; Horisawa et al. 2004; Råberg et al. 2005; Luchi et al. 2006) and matrix-assisted laser desorption/ionisation time-of-flight mass spectrometry (MALDI-TOF MS) (Schmidt and Kallow 2005) can be used to identify wood decaying fungi in wood samples. Here we showed that volatiles released by fungal-infected beech showed different patterns, including C8 compounds as common volatiles and sesquiterpenes as specific volatiles. These VOCs can be sensitively and selectively perceived by insects. For that reason, sampling the VOCs as metabolites from fungal action in combination with utilisation of insect olfaction is a promising method for wood quality assessment.

According to the traditional tests to fungal resistance of wood physical property, e. g., tensile strength and modulus of elasticity, they are usually performed after more than two to three weeks after incubation with fungi (Eaton and Hale 2003). This would make possible to create a detecting method for fungal-infested wood by mean of insect-antennabase biosensor as has been achieved as demonstrated by the detection of infested potatoes (Schütz et al. 1999), using a biosensor as a fast and non-destructive test method and is complement to the traditional testing methods. 


\subsection{References}

Abraham WR. 2001. Bioactive sesquiterpenes produced by fungi: are they useful for humans as well? Current Medical Chemistry 8: 583-606.

Begala M, Corda L, Podda G, Fedrigo MR, Traldi P. 2002. Headspace solid-phase microextraction gas chromatography/mass spectrometry in the analysis of the aroma constituents of 'Cannonau of Jerzu' wine. Rapid Communication in Mass Spectrometry 16: 1086-1091.

Bruce A, Stewart, D, Verrall S, Wheatley RE 2003. Effect of volatile from bacteria and yeast on the growth and pigmentation of sapstain fungi. International Biodeterioration and Biodegradation 51: 101-108.

Bruce A, Verrall S, Hackett CA, Wheatley RE. 2004. Identification of volatile organic compounds (VOCs) from bacterial and yeast causing growth inhibition of sapstain fungi. Holzforschung 58: 193-198.

Chitarra GS, Abee T, Rombouts FM, Posthumus MA, Diijksterhuis J. 2004. Germination of Penicillium paneum conidia is regulated by 1-octen-3-ol, a volatile self-inhibitor. Applied and Environmental Microbiology 70: 2823-2829.

Combet E, Henderson J, Eastwood DC. 2006. Eight-carbon volatiles in mushrooms and fungi: properties, analysis, and biosynthesis. Mycoscience 47: 317-326.

Coutts MP, Dolezal JE. 1969. Emplacement of fungal spores by the woodwasp, Sirex noctilio, during oviposition. Forest Science 15: 412-416.

Deng, C, Zhang J, Yu X, Zhang W, Zhang X. 2004. Determination of acetone in human breath by gas chromatography-mass spectrometry and solid-phase microextraction with on-fiber derivatization. Journal of Chromatography B 810: 269-275.

Eaton RA, Hale MDC. 1993. Wood - decay, pests and protection. Chapman \& Hall, Cambridge.

Ewen RJ, Jones PRH, Ratcliffe NM, Spencer-Phillips PTN. 2004. Identification by gas chromatography-mass spectrometry of the volatile organic compounds emitted from the wood-rotting fungi Serpula lacrymans and Coniophora puteana, and from Pinus sylvestris timber. Mycological Research. 108: 806-814.

Fäldt J, Jonsell M, Nordlander G, Borg-Karlson AK. 1999. Volatiles of bracket fungi Fomitopsis pinicola and Fomes fomentarius and their functions as insect attractants. Journal of Chemical Ecology 25: 567-590.

Far EE. 2001. Surface-to-air signals. Nature 411: 854-856.

Fiedler K, Schütz E, Geh S. 2001. Detection of microbial volatile organic compounds (MVOCs) produced by moulds on various materials. International Journal of Hygiene Environment Health 204: 111-121.

Griffith RT, Jayachandran K, Shetty KG, Whitstine W, Furton KG. 2007. Differentiation of toxic molds via headspace SPME-GC/MS and canine detection. Sensors 7: 1496-1508.

Horisawa S, Sakuma Y, Takata K, Doi S. 2004. Detection of intra- and interspecific variation of the dry rot fungus Serpula lacrymans by PCR-RFLP and RAPD analysis. Journal of Wood Science 50: 427-432.

Keller NC, Turner G, Bennett JW. 2005. Fungal secondary metabolism-from biochemistry to genomicsNature Reviews Molecular Cell Biology 3: 937-947.

León J, Rojo E, Sánchez-Serrano J. 2001. Wound signalling in plants. Journal of Experimental Biology 52: 1-9. 
Luchi N, Capretti P, Vettraino AM, Vannini A, Pinzani P, Pazzagli M. 2006. Early detection of Biscogniauxia nummularia in symtomless European beech (Fagus sylvatica L.) by TaqMan ${ }^{\mathrm{TM}}$ quantitative real-time PCR. Letter in Applied Microbiology 43: 33-38.

Matsui K. 2006. Green leaf volatiles: hydroperoxide lyase pathway of oxylipin metabolism. Current Opinion in Plant Biology 9: 274-280.

Meyer RL, Larsen LH, Revsbech NP. 2002. Microscale biosensor for measurement of volatile fatty acids in anoxic environments. Applied and Environmental Microbiology 68: 12041210.

Naumann A, Navarro-Gonzalez M, Peddireddi S, Kues U, Polle A. 2005. Fourier transform infrared microscopy and imaging: detection of fungi in wood. Fungal Genetics and Biology 42: 829-35.

Råberg U, Edlung M-L, Terziev N, Land CJ. 2005. Testing and evaluation of natural durability of wood in above ground conditions in Europe-an overview. Journal of Wood Science 51: 429-440.

Robert AZ, Morrell JJ. 1992. Wood microbiology, decay and its prevention. Academic Press, Inc. Califonia.

Schmidt O, Kallow W. 2005. Differentiation of indoor wood decay fungi with MALDI-TOF mass spectrometry. Holzforschung 59: 374-377.

Schütz S, Weißbecker B, Koch UT, Hummel HE. 1999. Detection of volatiles released by diseased potato tubers using a biosensor on the basis of intact insect antennae. Biosensors and Bioelectronics 14: 221-228.

SooKyung O, Kamdem DP, Keathley DE, Han KH. 2003. Detection and species identification of wood-decaying fungi by hybridization of immobilized sequence-specific oligonucleotide probes with PCR-Amplified fungal ribosomal DNA internal transcribed spacers. Holzforschung 57: 346-352.

Sunesson A-L, Vaes, WHJ, Nilsson C-A, Blomquist G, Andersson B, Carlson R. 1995. Identification of volatile metabolites from five fungal species cultivated on two media. Applied and Environmental Microbiology 61: 2911-2918.

Thakeow P, Holighaus G, Schütz S. 2007. Volatile compounds for wood assessment. In: Kües U. (Ed). Wood production, wood technology and biotechnological impacts. Universitätsverlag Göttingen, Göttingen. pp. 197-228.

Thakeow P, Angeli S, Weissbecker B, Schütz S. 2008. Antennal and behavioural responses of fungivorous insect Cis boleti to fungal odour of Trametes gibbosa. Chemical Senses 33: 379387.

Thakeow P, Chaisaena W, Kües U, Schütz S. Volatile organic compounds released during Coprinopsis cinerea fruiting body development. Manuscript in preparation.

Tressl R, Bahri D, Engle KH. 1982. Formation of eight-carbon and then-carbon components in mushrooms (Agaricus campestris). Journal of Agriculture and Food Chemistry 30: 89-93.

Trihaas J, van den Tempel T, Nielsen PV. 2005. Electronic nose technology in quality assessment: predicting volatile composition of Danish blue cheese during ripening. Journal of Food Science 70: E392-E400.

Yu J-H, Keller N. 2005. Regulation of secondary metabolism in filament fungi. Annual Review of Phytopathology 43: 437-458.

van den Velde S, Quirynen M, Van hee P, van Steenberghe D. 2007. Halitosis associated volatiles in breath of healthy subjects. Journal of Chromatography B 853: 54-61. 
Wurzenberger M, Grosch W. 1982. The enzymic oxidative breakdown of linoleic acid in mushrooms (Psalliota bispora). Zeitschrift für Lebensmittel-Untersuchung und-Forschung 175: 186-190.

Zabel R., Morrel JJ. 1992. Wood microbiology-Decay and its prevention. Academic Press, Inc. New York.

Zeppa S, Gioacchini AM, Guidi C, Guescini M, Pierleoni R, Zambonelli A, Stocchi V. 2004. Determination of specific volatile organic compounds synthesised during Tuber borchii fruiting body development by solid-phase microextraction and gas chromatography/mass spectrometry. Rapid Communication in Mass Spectrometry. 18: 199-205. 


\title{
CHAPTER 4
}

\section{Volatile Organic Compounds Released during Coprinopsis cinerea Fruiting Body Development}

\author{
Prodpran Thakeow, Wassana Chaisaena, Ursula Kües,
}

\author{
and Stefan Schütz
}

\begin{abstract}
This work had been done in cooperation with the working group of Prof. Dr. Ursula Kües, Section of Molecular Wood Biotechnology at the Büsgen Institute, Georg-AugustUniversity of Göttingen. Wassana Chaisaena had prepared fungal cultures, sampled volatiles and written some parts of the manuscript. Prof. Dr. Ursula Kües and Prof. Dr. Stefan Schütz had provided useful advice, idea, and critical comment in this work. This chapter is in manuscript preparation step and planned to submit to Mycological Research.
\end{abstract}





\subsection{Abstract}

Volatile organic compounds (VOCs) released during the fruiting body development of the basidiomycete Coprinopsis cinerea were monitored. The fruiting body development begins after the formation of hyphal aggregates (hyphal knots). During, primordia development cap and stipe tissue differentiate triggered by light. In the following three days then the primordia become mature and karyogamy occurs in the basidia. This process activates onset of fruiting body maturation. Over a night, mushrooms are shaped and basidiospores are released in the day after by cap autolysis. The headspace (HS)-VOCs released in these stages was collected using a passive sampling with solid phase microextraction. Afterwards, the adsorbed HS-VOCs were analysed using gas chromatography-mass spectrometry. Seventeen volatiles were identified, and four of them, 1-octen-3-ol, 3octanone, $\beta$-himachalene and cuparene were quantitatively observed during the development. 1-octen-3-ol and 3-octanone were substantially released during primodia formation and were gradually reduced in later stages. In the same time, the two sesquiterpenes $\beta$-himachalene and cuparene were steadily released during the primordia formation, and drastically increased in amount when the stipe of $C$. cinerea elongated and C. cinerea fruiting body became mature. Possible roles during fungal development and in interspecies interaction are discussed.

Keywords: Basidiomycetes, VOCs, GC-MS, SPME, 1-octen-ol, 3-octanone, cuparene, $\beta$ himachalene 


\subsection{Introduction}

In developmental process study of homobasidiomycetous fungi, Coprinopsis cinerea (formerly known as Coprinus cinereus) is one of the model organisms used since it shows a within-two-week life cycle development (Kües 2000). The growth of C. cinerea starts from the mycelium as the vegetative stage in the dark. Triggered by light condition, the hyphal aggregates (hyphal knots) are formed. Then, cap and stipe tissues differentiate (primordia development) in the following three days. When the primordia become mature, karyogamy occurs in the basidia, inducing the beginning of fruiting body formation. The fruiting body is developed overnight and in the next day basidiospores are released by cap autolysis. $C$. cinerea has been well studied in several research areas, for example, identification and characterization of fungal multi-copper oxidase gene families (Kilaru et al. 2006), developmental process and genetic studies in the basidiomycetes (Moore 1981; Kües 2000; Walser et al. 2003; Terashima et al. 2005; Lui et al. 2006; Srivilai et al. 2006), morphological investigation (Moore 1998; Moore et al 1979; Chaisaena et al. 2007; Navarro-González et al. 2005) and biomechanics of stipe elongation (Money and Ravishankar 2005). Nevertheless, none of them was focused on volatile organic compounds (VOCs) of $C$. cinerea and their possible link to fungal metabolisms.

VOCs have been recently and increasingly used as a qualification-evaluation method, for instance, investigation of VOCs for studying in biological process in basidiomycetes (Sugihara and Humfeld 1954; Sánchez 2004), wood quality assessment (Ewen et al. 2004; Thakeow et al. 2007), sick-building syndrome appraisal (Korpi et al. 1998; Nilsson et al. 2004), diabetic detection in medicine (Deng et al. 2004) and meat spoilage detection in food industry (Mayr et al. 2003). Therefore, together with analytical technology, using volatiles or volatile patterns are a promising indication method for monitoring $C$. cinerea fruiting body development.

In this study, we investigated VOCs released during the fruiting body development of C. cinerea. The correlation of the VOCs with fungal growth might provide a promising tool for non-invasive observation of biochemical process during fungus development. 
Moreover, VOCs specific for discrete developmental stages of the fungus might yield a definition of ecological niches for mycelial feeding and fruiting body feeding fungivorous insects.

\subsection{Materials and methods}

\subsubsection{C. cinerea Strain}

C. cinerea strain AmutBmut (A43mut, B43mut, pab1), a self-compatible homokaryon that forms fruiting body and oidia in a light-regulated manner (Swamy et al. 1984; May et al. 1991; Kertesz-Chaloupková et al. 1998; Kües 2000), was used for investigating VOCs released during life cycle development.

\subsubsection{Culture preparation}

The YMG/T medium was prepared by mixing 0.4\% yeast extract (Oxoid Ltd., Hamshire, England), 1\% malt extract (Oxoid Ltd., Hamshire, England), 0.4\% D-(+)-glucose monohydrate (Applichem GmbH, Darmstadt, Germany) and 0.01\% L-tryptophan (Carl Roth GmbH, Karlsruhe, Germany) in distilled water. Then it was autoclaved at $121^{\circ} \mathrm{C}$ for $20 \mathrm{~min}$. After that, $10 \mathrm{ml}$ of this medium were poured into a $60-\mathrm{ml}$ vial and the vial was loosely closed with a septum cap and left on a slope holder to form an agar slant.

C. cinerea was inoculated in the middle of the prepared agar slant and the vial was loosely closed in order to allow the aeration. The cultures were incubated for four days at $37^{\circ} \mathrm{C}$ in the darkness for the vegetative growth before they were transferred to an incubator room with the conditions of $12 \mathrm{~h}$ dark $/ 12 \mathrm{~h}$ light cycle at $28^{\circ} \mathrm{C}$ and $80-90 \%$ humidity. 


\subsubsection{Volatile sampling}

The passive sampling technique of solid phase microextraction (SPME) was employed to collect volatiles released to the headspace of the vial. The sketch of this tool is shown in Figure 4-1. SPME, $85 \mu \mathrm{m}$ Carboxen $^{\mathrm{TM}} /$ Polydimethylsiloxane (PDMS) StableFlex $^{\mathrm{TM}}$ fibre type (Supelco, USA) was used for sampling volatiles which released to the vial headspace. Before sampling the fibre was cleaned and sterile by exposing it into the GC injection port at $250^{\circ} \mathrm{C}$ for $5 \mathrm{~min}$. For volatile collection, the SPME needle was inserted through the septum. The fibre, housed inside the needle, was exposed to the headspace of vial. The exposure time was 0.5 and 24 hrs.

Figure 4-1 SPME-Volatile sampling method.

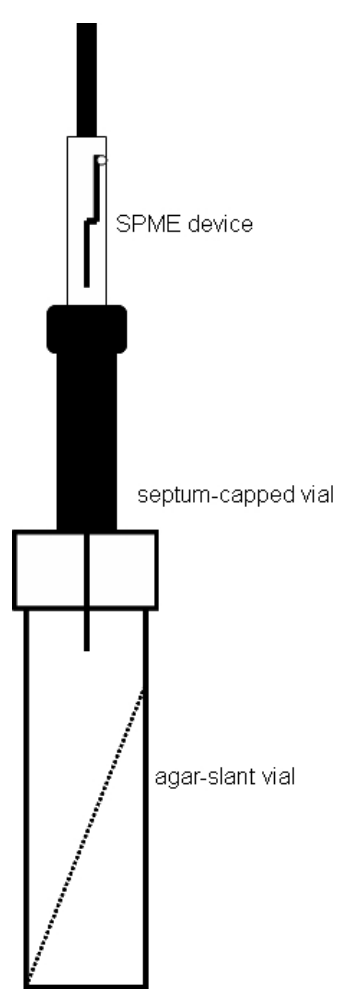




\subsubsection{Volatile Analysis with Gas Chromatography-Mass Spectrometry (GC-MS)}

To analyse the chemical components of the VOC mixture, a gas chromatograph (GC, HP 6890N, Agilent Technologies, Paolo Alto, USA) was coupled to a mass spectrometer (MS, 5973, Agilent Technologies, Paolo Alto, USA). The column used was non polar type, HP5MS (Agilent Technologies, Paolo Alto, USA), $30 \mathrm{~m}$ x $0.25 \mathrm{~mm}$ i.d., $0.25 \mu \mathrm{m}$ film thickness. For analzing VOCs, the volatile-loaded fibre was inserted into the injection port $\left(250^{\circ} \mathrm{C}\right)$ and then the desorbed volatiles were run through the column with helium as a carrier gas

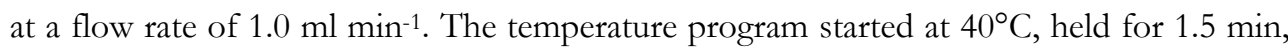
heated with a rate of $6.0^{\circ} \mathrm{C} \mathrm{min}^{-1}$ to $200^{\circ} \mathrm{C}$ and held at this temperature for $5 \mathrm{~min}$.

The mass spectrometer was operated in the scan mode in a range of 20-300 amu, a source temperature of $230^{\circ} \mathrm{C}$, and EI mode at $70 \mathrm{eV}$. The preliminary interpretation of the chromatograms were carried out by matching mass spectra with Enhanced chemstation version D00.00.38 (Agilent Technologies, Paolo Alto, USA), the Mass Spectral Search library of the National Institute of Standards and Technology (NIST, Gaithersburg, USA), and the database of Massfinder version 3.0 software together with the library "Terpenoids and Related Constituents of Essential Oils" (Hochmuth, König, Joulain, Hamburg, Germany). The interpretation was confirmed by evaluating mass spectra and retention times with those of authentic standards. The quantification of major constituents was done by five-point calibration of standard compounds and evaluation of peak areas in the selected ion monitoring mode.

\subsubsection{Principle component analysis (PCA)}

In order to preliminarily differentiate the $C$. cinerea volatiles from the experimental chromatograms, Pirouette program version 3.11 (Infometrix Inc., Washington, USA) was used. This program was designed for direct analysis of chromatogram data by mean of mass perion $(\mathrm{m} / \mathrm{z})$. 


\subsection{Results}

\subsubsection{C. cinerea culture}

Fruiting body development and morphology of C. cinerea are shown in Figure 4-2. After four days at $37^{\circ} \mathrm{C}$ in darkness, mycelium grew cover the whole surface of the YMG/T slant. At this stage of development, the hyphal knots had been developed. It took about eleven days from inoculation of $C$. cinerea plug on $\mathrm{YMG} / \mathrm{T}$ slant till autolysis stage of the fruiting body, where black spores were released. The development of $C$. cinerea was well described by Chaisaena et al. 2007 and Navarro-González et al. 2005.

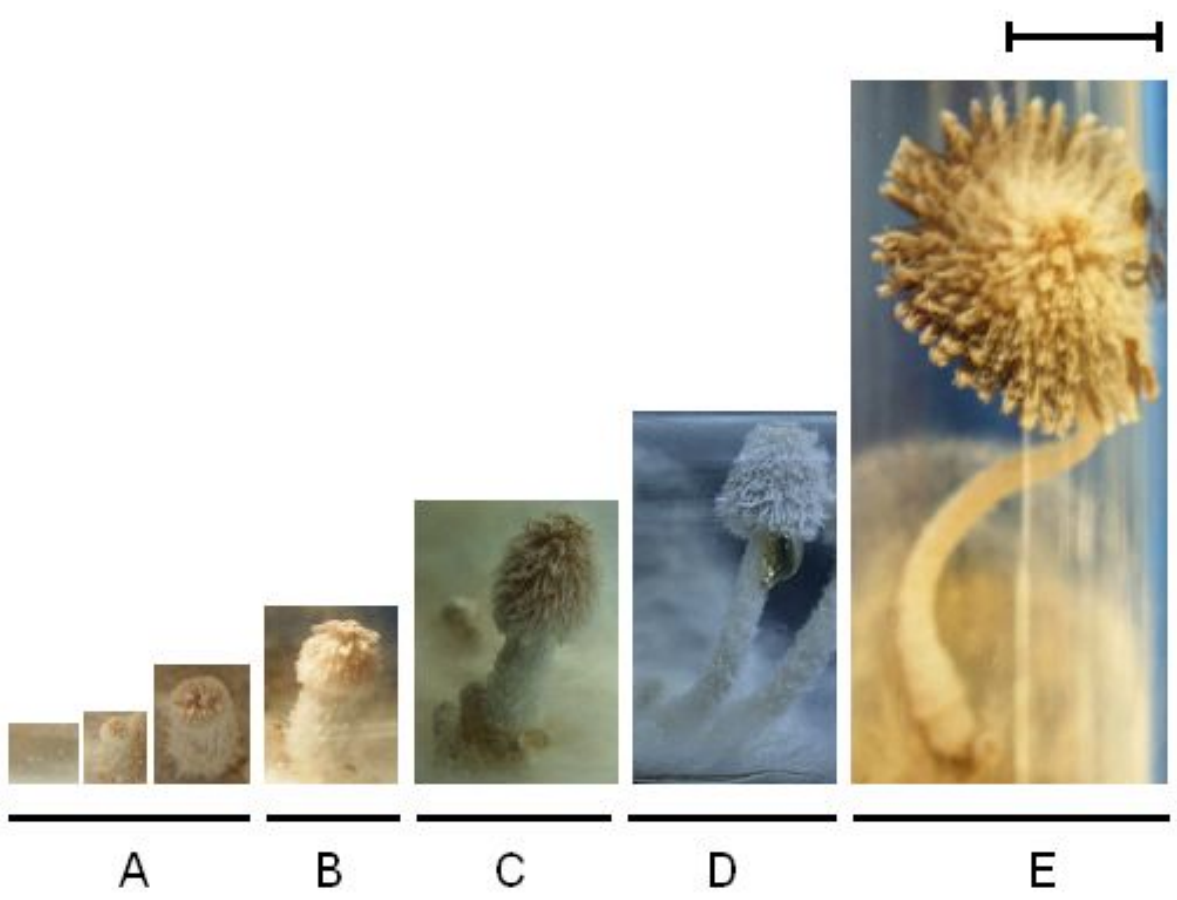

Figure 4-2 Fruiting body development of Coprinopsis cinerea. A: primodia (day 0-4), B: mature primodia (day 5), C: immature fruiting body (day 5), D: mature fruiting body (day 5) and E: fruiting body autolysis (day 6). Bar: $1 \mathrm{~cm}$. Photograph D by courtesy of W. Chaisaena. 


\subsubsection{Principle component analysis (PCA) of $C$. cinerea volatiles}

Volatiles released during the growth of $C$. cinerea were preliminarily examined using Pirouette program version 3.11 (Infometrix Inc., Washington, USA). It was found that volatiles from the whole stage of development were approximately grouped into four developmental stages, mycelium, primodia, fruiting body and autolysis (Figure 4-3A). The mass ions which obviously separated the volatiles were 43, 57, 119 and $132 \mathrm{~m} / \mathrm{z}$ (Figure 43B).
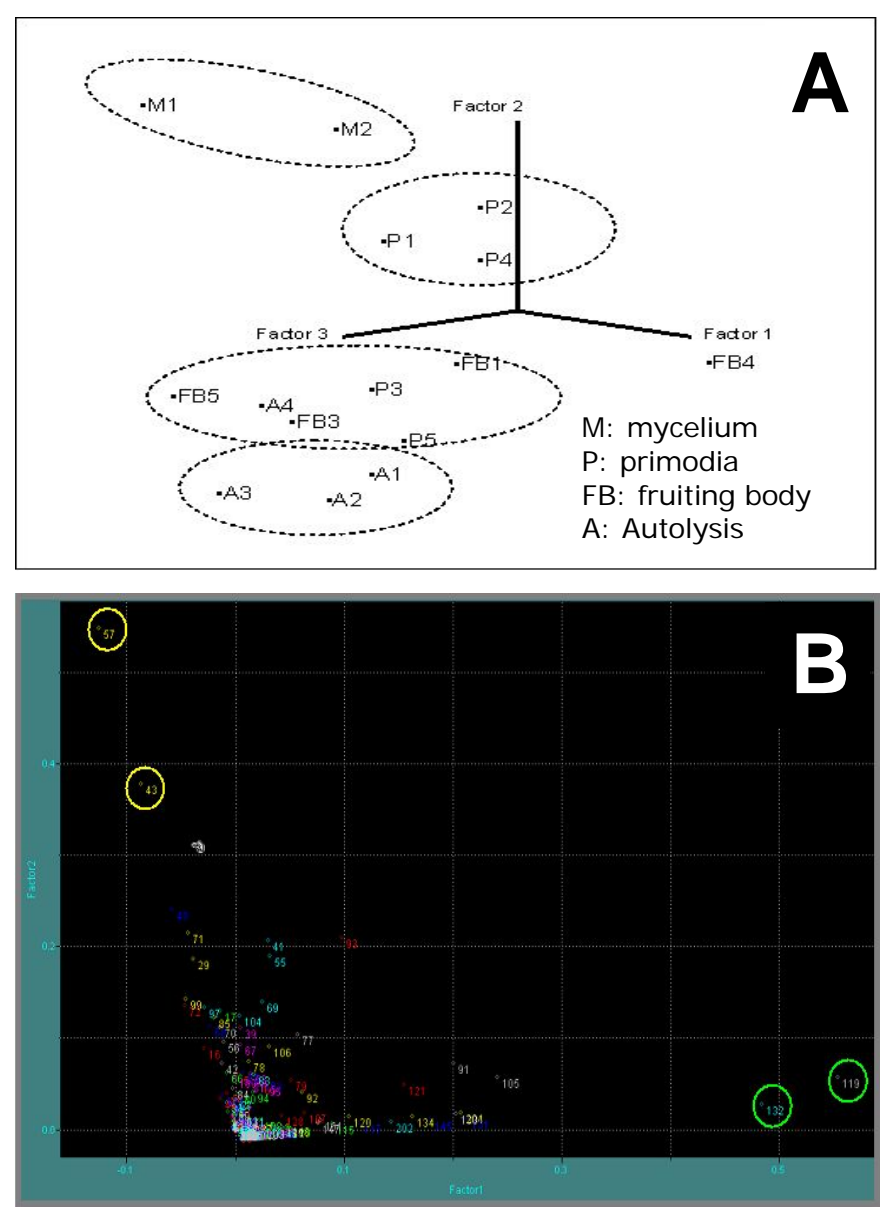

Figure 4-3 Principal component analysis (PCA) of Coprinopsis cinerea volatiles. A: During the life cycle development. B: Differentiation by mass per ion $(\mathrm{m} / \mathrm{z})$. 


\subsubsection{Volatiles of wild type $C$. cinerea (AmutBmut)}

After four days at $37^{\circ} \mathrm{C}$ in the darkness for the vegetative growth, the $C$. cinerea mycelium developed and covered the whole surface of $\mathrm{YMG} / \mathrm{T}$ slant. Then, it was moved to the incubator room, $28^{\circ} \mathrm{C}$ and $80-90 \% \mathrm{RH}$, where the fruiting body developed and the volatiles were sampled. As shown in Table 4-1 and Figure 4-4, 17 compounds were detected and 14 compounds were identified of the volatiles released during the $C$. cinerea fruiting body development. Those volatiles were detected through the whole fungal development, but some of them varied in quantities. The peaks without numbers were found also in the YMG/T control, therefore they were not assigned. Two compounds of typical fungal odours (Combet et al. 2006), 1-octen-3-ol and 3-octanone, were found throughout the whole period of the experiment. However, the quantities of these eight-carbon containing

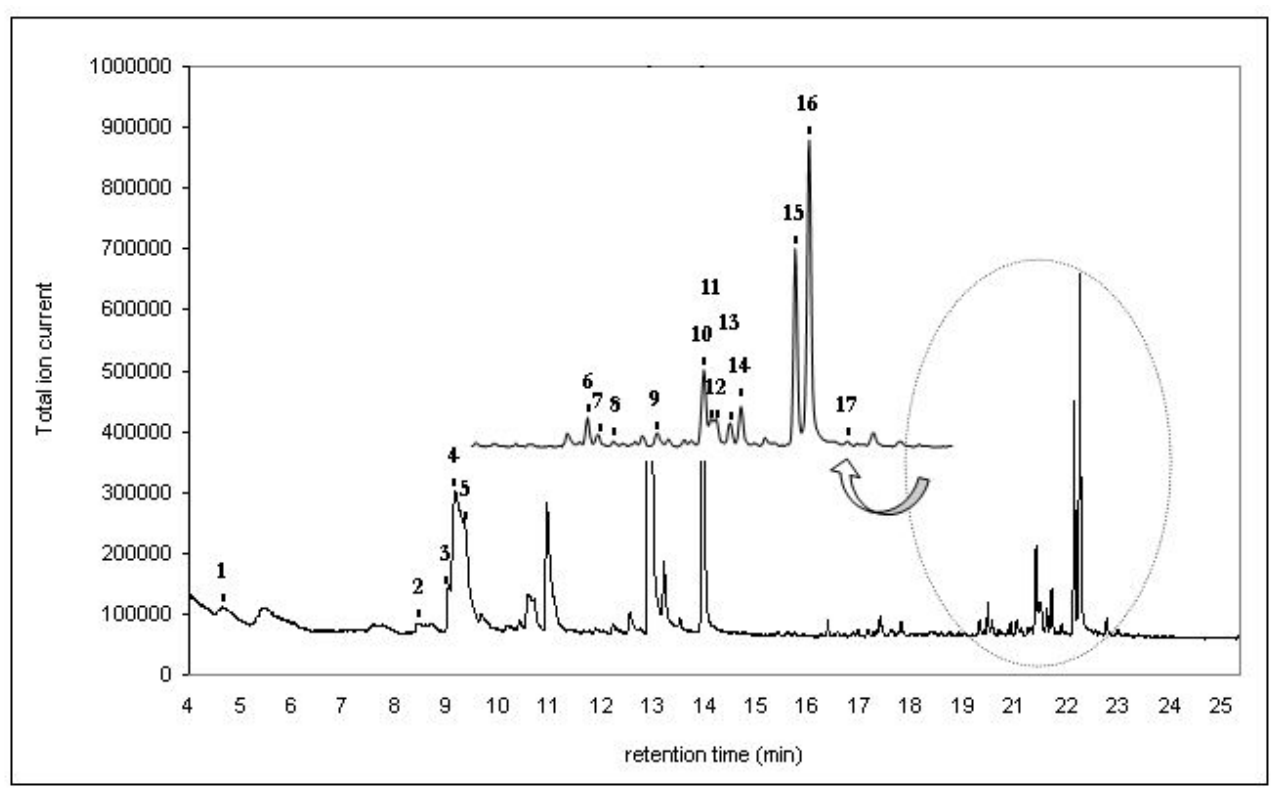

Figure 4-4 A gas chromatogram of volatiles released in day 6 (mature fruiting body of Coprinopsis cinerea). Sampling by SPME for $24 \mathrm{hrs}$. Identified compounds (numbered peaks) are shown in Table 4-1. The peaks which are not numbered are also found in the YMG/T. 
compounds (C8 compounds) changed during the fruiting body development process (Figure 4-5). After two days exposing to light, the primodia developed, where 1-octen-3-ol was released at the highest quantities, and they were gradually reduced in the later stages. In addition to those compounds, there were 13 sesquiterpenes detected. $\beta$-himachalene (tentatively identified) and cuparene were increasingly released during the stipe elongation and through autolysis as shown in Figure 4-5.

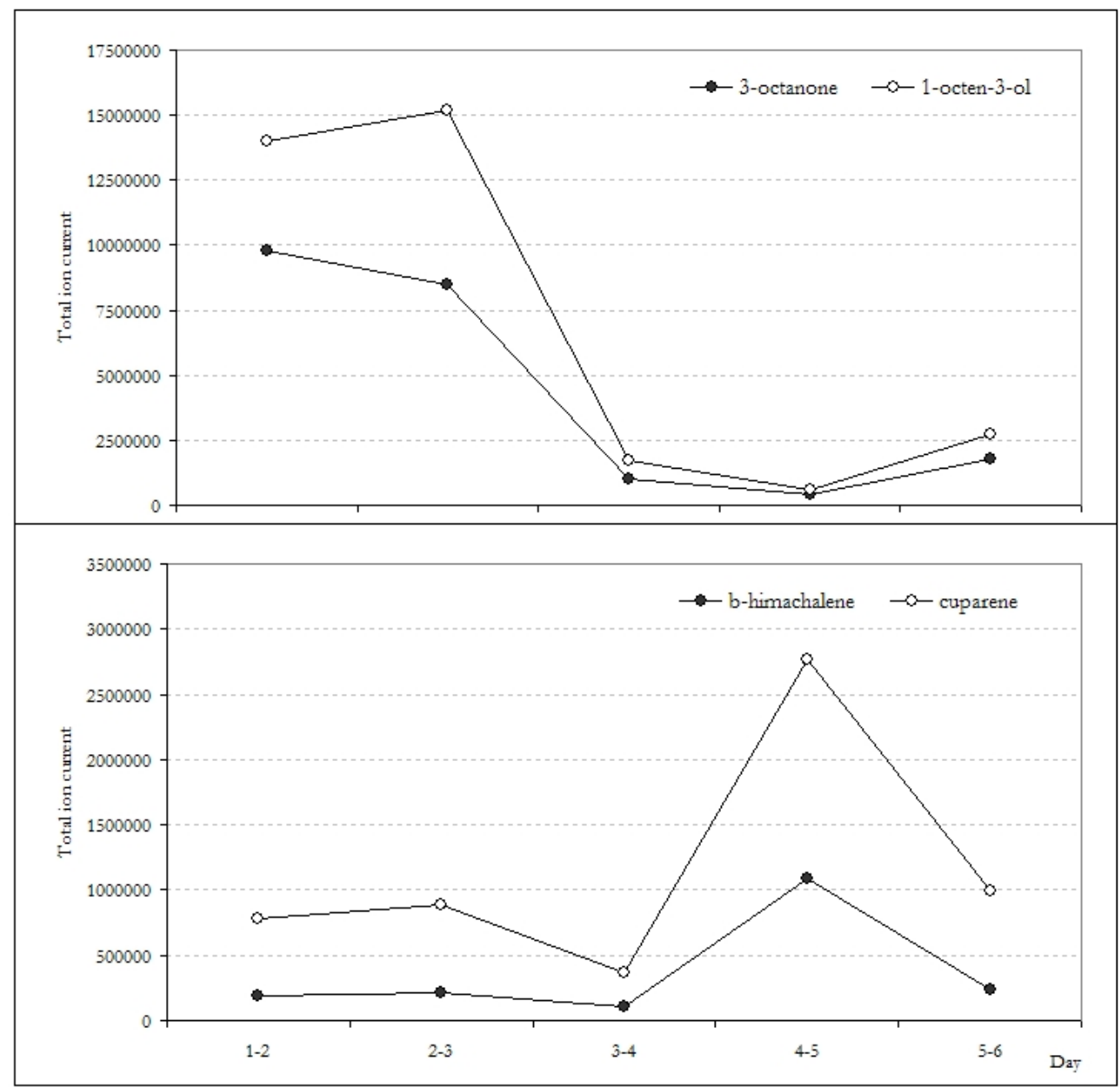

Figure 4-5 Alteration of 1-octen-3-ol, 3-octanone, $\beta$-himachalene and cuparene during Coprinopsis cinerea fruiting body development. Sampling by using SPME for 24 hours. 
Table 4-1 Volatiles released during fruiting body development of Coprinopsis cinerea

\begin{tabular}{|c|c|c|c|}
\hline Peak No. & Compounds & Chemical structure & Identification* \\
\hline 1 & $\begin{array}{l}\text { 1-butyl-2- } \\
\text { methylcyclopropane/octene }\end{array}$ & & \\
\hline 2 & $\begin{array}{l}\text { dihydro-3-methyl-2(3H)- } \\
\text { furanone }\end{array}$ & & $70 \%$ a \\
\hline 3 & $\begin{array}{l}\text { 4-ethyl-1,3- } \\
\text { cyclopentanedione }\end{array}$ & & $74 \%^{\text {a }}$ \\
\hline 4 & 1-octen-3-ol & & standard \\
\hline 5 & 3-octanone & & standard \\
\hline 6 & $\alpha$-cedrene & & $83 \%^{a}$ \\
\hline 7 & $\begin{array}{l}\text { 1,2,3,4,6,8a-hexahydro-1- } \\
\text { isopropyl-4,7-dimethyl- } \\
\text { naphthalene }\end{array}$ & & $93 \%^{a}$ \\
\hline 8 & $\begin{array}{l}(+) \text {-epi- } \\
\text { bicyclosesquiphellandrene }\end{array}$ & & $95 \%$ a \\
\hline 9 & unidentified sesquiterpene & - & - \\
\hline
\end{tabular}


Table 4-1 - continued

\begin{tabular}{|c|c|c|c|}
\hline Peak No. & Compounds & Chemical structure & Identification* \\
\hline 10 & $\alpha$-cubebene & & $92 \%$ a \\
\hline 11 & unidentified sesquiterpene & - & - \\
\hline 12 & $\beta$-cubebene & & $86 \%{ }^{a}$ \\
\hline 13 & unidentified sesquiterpene & - & - \\
\hline 14 & $\beta$ - chamigrene & & $94 \%$ a \\
\hline 15 & $\beta$-himachalene & & $98 \%{ }^{a}$ \\
\hline 16 & $(+)$-cuparene & & standard $^{* *}$ \\
\hline 17 & calamenene & & $94 \%$ a \\
\hline
\end{tabular}

* Identification was carried out by comparing the verified compounds with mass spectra and retention indices with internal database and co-elution with authentic standards: Merck, Darmstadt, Germany

${ }^{a}$ preliminary identification by two different sampling methods (percent of similarity to databases) 


\subsection{Discussion}

To our knowledge, this paper reports the first description of volatiles released during life cycle development of $C$. cinerea from the different developmental stages of hyphal-knot mycelium, stipe tissues differentiation (primordia development), fruiting body and autolysis. Principle component analysis using Pirouette program can be used for preliminary identification of VOCs released from $C$. cinerea life cycle development. The mycelial and fruiting body stages are completely separated by different abundance of C8 compounds (m/z 57 and 43) and sesquiterpenes (m/z 119 and 132). Those compounds were, later on identified by comparing of mass spectra and retention indices with our internal database and co-elution with authentic standards, 1-octen-3-ol, 3-octanone, cuparene and $\beta$-himachalene.

In this experiment, the two compounds of 1-octen-3-ol and 3-octanone, well-known as the typical fungal odours (FOs), were found during the whole fungal development. 1octen-3-ol, recognised as a mushroom-like aroma (Tressl et al. 1982; Mau et al. 1997; Nidiry 2001), was found to be abundantly released in the mycelium stage and was gradually reduced during fruiting body formation. A similar phenomenon was observed regarding the abundance of 3-octanone. There have been reports on the 1-octen-3-ol formation, i.e., in Agaricus campestris (Tressl et al. 1982), in Pleurotus pulmonarius (Assaf et al. 1997), in Lentinus decadetes (Matsui et al. 2003) and in Lentinula edodes and Tricholoma matsutake (Akakabe et al. 2005). In addition, different pathways from linoleic acid to 1octen-3-ol have been proposed, those are, for example, via hydroperoxide lyase enzymatic reaction of (10E,12Z)-9-hydroperoxyoctadeca-10,12-dienoic acid (9-HPOD) (Tressl et al. 1982), of (8E,12Z)-9-hydroperoxyoctadeca-8,12-dienoic acid (10-HPOD) (Wurzenber and Grosch 1982) and homolytic cleavage of 10-HPOD (Combet et al. 2006). In plants, the analogous 6-carbon (C6) containing compounds known as green leave volatiles (GLVs) (Visser 1979) are believed to function as intra- and interplant volatile signals (Matsui 2006). However, it is not clear whether the C8 compounds have similar functions. Recently it was found that 1-octen-3-ol in Penicillium paneum plays an important role in conidia germination as a volatile self-inhibitor (Chitarra et al. 2004). 
Cuparene and $\beta$-himachalene were detected from beginning in minute quantities and sharply increased during the fruiting body formation. It was found that cuparene-type sesquiterpenes from a mycelial culture of Flammulina velutipes proved an antimicrobial activity against the fungus Clodosporium herbarum, and the bacteria Bacillus subtilis and Staphylococcus aureus (Ishikawa et al. 2001). Additionally, $\beta$-himachalene, as a component in essential oils of Vigna mungo and Chamaecyparis obtusa showed antimicrobial activity as well (Singh and Tripathi 1999; Yang et al. 2007). These two sesquiterpenes might serve as antibiotic compounds to protect the spores of $C$. cinerea. Consequently, altogether cuparene and $\beta$-himachalene released during the formation of $C$. cinerea fruiting body could prevent the infestation by other microorganisms and ensure that the germination of the spores will be successful. C8 compounds and sesquiterpenes are prime candidates for mediating species specific interaction between fungi and insects (Fäldt et al. 1999; Thakeow et al. 2007, 2008). Moreover, they might become an important tool to investigate developmental process involving fungal liopoxygenase-like signalling pathways with high time resolution on individual fungi.

\subsection{References}

Akakabe Y, Matsui K, Kajiwara T. 2005. Stereochemical correlation between 10hydroperoxyoctadecadienoic acid and 1-octen-3-ol in Lentinula edodes and Tricholoma matsutake mushrooms. Bioscience, Biotechnology and Biochemistry 69: 1539-1544.

Assaf S, Hadar Y, Dosoretz CG. 1997. 1-octen-3-ol and 13-hydroperoxylinoleate are products of distinct pathways in the oxidative breakdown of linoleic acid by Pleurotus pulmonarius. Enzyme and Microbial Technology 7: 65-70.

Chaisaena W, Granado J, Navarro-González, Srivilai P, Aebi M, Kües U. 2007. Defects in Light-regulation of development in the basidiomycete Coprinopsis cinerea. In press.

Chitarra GS, Abee T, Rombouts FM, Posthumus MA, Diijksterhuis J. 2004. Germination of Penicillium paneum conidia is regulated by 1 -octen-3-ol, a volatile self-inhibitor. Applied and Environmental Microbiology 70: 2823-2829.

Combet E, Henderson J, Eastwood DC, Burton KS. 2006. Eight-carbon volatiles in mushrooms and fungi: properties, analysis, and biosynthesis. Mycoscience 47: 317-326.

Deng C, Zhang J, Yu X, Zhang W, Zhang X. 2004. Determination of acetone in human breath by gas chromatography-mass spectrometry and solid-phase microextraction with on-fiber derivatization. Journal of Chromatography B 810: 269-275.

Ewen JR, Jones RHP, Ratcliffe MN, Spencer-Phillips TNP. 2004. Identification by gas chromatography-mass spectrometry of the volatile organic compounds emitted from the 
wood-rotting fungi Serpula lacrymans and Coniophora puteana, and from Pinus sylvestris timber. Mycological Research 7: 806-814.

Fäldt J, Jonsell M, Nordlander G, Borg-Karlson AK. 1999. Volatiles of bracket fungi Fomitopsis pinicola and Fomes fomentarius and their functions as insect attractants. Journal of Chemical Ecology 25: 567-590.

Ishikawa NK, Fukushi Y, Yamaji K, Tahara S, Takahashi K. 2001. Antimicrobial cuparenetype sesquiterpenes, Enokipodins C and D, from a mycelial culture of Flammulina velutipes. Journal of Natural Products 64: 932-934.

Kertesz-Chaloupková K, Walter PJ, Granado JD, Aebi M, Kües U. 1998. Blue light overrides repression of asexual sporulation by mating type genes in the basidiomycete Coprinus cinereus. Fungal Genetic Biology 23: 95-109.

Kilaru S, Hoegger PJ, Kües U. 2006. The laccase multi-gene family in Coprinopsis cinerea has seventeen different members that divide into two distinct subfamilies. Current Genetics 50: 45-60.

Korpi A, Pasanen A-L, Viitanen H. 1998. Volatiles metabolites of Serpula lacrymans, Coniophora puteana, Poria placenta, Stachybotrys chartarum and Chaetomium globosum. Building and Environment 34: 205-211.

Kües U. 2000. Life history and development processes in the basidiomycete Coprinus cinereus. Microbiology and Molecular Biology Reviews 64: 316-353.

Liu Y, Srivilai P, Loos S, Aebi M, Kües U. 2006. An essential gene for fruiting body initiation in the basidiomycete Coprinus cinereus is homologous to bacterial cyclopropane fatty acid synthase genes. Genetics 172: 873-884.

Matsui K, Sasahara S, Akakabe Y, Kajiwara T. 2003. Linoleic acid 10-hydroperoxide as an intermediate during formation of 1-octen-3-ol from linoleic acid in Lentinus decadetes. Bioscience, Biotechnology and Biochemistry 67: 2280-2282.

Matsui K. 2006. Green leaf volatiles: hydroperoxide lyase pathway of oxylipin metabolism. Current Opinion in Plant Biology 9: 274-280.

Mau JL, Chyau CC, Li JY, Tseng YH. 1997. Flavor compounds in straw mushrooms Volvariella volvacea harvested at different stages of maturity. Journal of Agricultural and Food Chemistry 45: 4587-4591.

May G, Le Chevanton, Pukkila PJ. 1991. Molecular analysis of the Coprinus cinereus mating type $A$ factor demonstrated an unexpectedly complex structure. Genetics 128: 529-538.

Mayr D, Margesin R, Klingsbichel E, Hartungen E, Jenewein D. 2003. Rapid detection of meat spoilage by measuring volatile organic compounds by using proton transfer reaction mass spectrometry. Applied and Environmental Microbiology 69: 4697-4705.

Money NP, Ravishankar JP. 2005. Biomechanics of stipe elongation in the basidiomycete Coprinopsis cinerea. Mycological Research 109: 627-634.

Moore D. 1981. Developmental genetics of Coprinopsis cinereus: genetic evidence that carpophores and sclerotia share a common pathway of initiation. Current Genetics 3: 145150.

Moore D. 1998. Fungal morphogenesis. Cambridge University press, Cambridge, United Kingdom.

Moore D, Elhiti MMY, Butler RD. 1979 Morphogenesis of the carpophore of Coprinus cinereus. New Phytologist 66: 377-382.

Navarro-González M, Kilaru S, Majcherczyk A, Kües U. 2005. Copper in fruiting body development of Coprinus cinereus. Congress genetics and cellular biology of basidiomycetes VI, Pamplona, Spain, Abstract book, poster 31. 
Nidiry ESJ. 2001. Structure-fungitoxicity relationships of some volatile flavour constituents of the edible mushrooms Agaricus bisporus and Pleurotus florida. Flavour and Fragrance Journal 16: $245-248$.

Nilsson A, Khilström E, Lagesson V, Wessén B, Szponar B, Larsson L, Tagesson C. 2004. Microorganisms and volatile organic compounds in airborne dust from damp residences. Indoor Air 14: 74-82.

Sánchez C. 2004. Modern aspects of mushroom culture technology. Applied Microbiology and Biology 64: 756-762.

Srivilai P, James TY, Vilgalys R, Chaisaena W, Kües U. 2006. Heterologous expression of mating type genes in basidiomycetes. In: Proc. "Genetics and Cellular Biology of Basidiomycetes VI." Pamplona, 3-6 June 2005, Spain. In press.

Singh J, Tripathi NN. 1999. Inhibition of storage fungi of blackgram (Vigna mungo L.) by some essential oils. Flavour and Fragrance 14: 1-4.

Sugihara TF, Humfeld H. 1954. Submerged culture of mycelium of various species of mushroom. Applied Microbiology 2: 170-172.

Swamy S, Uno I, Ishikawa T. 1984. Morphogenic effects of mutations at the $A$ and $B$ inconpatability factors in Coprinopsis cinereus. Journal of General Microbiology 130: 32193224.

Terashima K, Yuki K, Muraguchi H, Akiyama M, Kamada T. 2005. The dst1gene involve in mushroom photomorphogenesis of Coprinus cinereus. Encodes a putative photoreceptor for blue light. Genetics 171: 101-108.

Thakeow P, Angeli, S, Weißbecker B, Schütz S. 2008. Antennal and behavioural responses of Cis boleti to fungal odour of Trametes gibbosa. Chemical Senses 33: 379-387.

Thakeow P, Holighaus G, Schütz S. 2007. Volatile compounds for wood assessment. In: Kües U. (Ed). Wood production, wood technology and biotechnological impacts. Universitätsverlag Göttingen, Göttingen. pp. 197-228.

Tressl R, Bahri D, Engel K-H. 1982. Formation of eight-carbon and ten-carbon components in mushrooms (Agaricus campestris). Journal of Agricultural Food and Chemistry 30: 89-93.

Visser JH. 1979. Electroantennogram responses of the Colorado beetle Leptinotarsa decemlineata to plant volatiles. Entomologia Experimentalis et Applicata 25: 86-97.

Walser PJ, Velagapudi R, Aebi M, Kües U. 2003. Extracellular matrix proteins in mushroom development. Recent Research Development in Microbiology 7: 381-415.

Wurzenberger M, Grosch W. 1982. The enzymic oxidative breakdown of linoleic acid in mushrooms (Psalliota bispora). Zeitschrift für Lebensmittel-Untersuchung und-Forschung 175: 186-190.

Yang JK, Choi M-S, Seo W-T, Rinker DL, Han SW, Cheong G-W. 2007. Chemical composition and antimicrobial activity of Chamaecyparis obtusa leaf essential oil. Fitoterapia 78: 149-152. 



\section{CHAPTER 5}

\section{External Antennal Morphology and Sensillar Type \\ Distribution of Cis boleti \\ (Coleoptera: Ciidae)}

Prodpran Thakeow, Sergio Angeli, and Stefan Schütz

This chapter presents a research manuscript written for submission to the journal

"Arthropod Structure \& Development". The insect preparations, the experimental work were preformed by Prodpran Thakeow. The manuscript was written by all authors. 



\subsection{Abstract}

Cis boleti is a specialist fungivorous insect, spending most of its life cycle in the fruiting body of Trametes spp. (Basidiomycete: Polyporaceae). The adults of this species are able to discriminate fungal volatile compounds, where 1-octen-3-ol was the key compound perceived. In this study, we carried out a morphological study on antennae of male and female adults by light microscopy and scanning electron microscopy, in order characterise the structure and the distribution of various types of sensilla of this species. C. boleti has a classical clubbed antenna formed by ten antennomers, where the distal part comprised a distinctly 3-segmented club. No sexual dimorphism was observed between the male and female antennae. The major types of sensilla were observed on the distal three antennomers and were categorised in four morphological types: long and short sensilla trichodea, sensilla basiconica and sensilla coeloconica. Long s. trichodea occurred on the distal part of each of the last 3 antennomers, while short $s$. trichodea were distributed over the entire surface of the antennal segments, with a higher density on the apex of the $10^{\text {th }}$ segment. Basiconic sensilla were restricted to 4 clusters on the lateral apical corners of each of the last three antennomers. Each cluster strongly reassembled an "octopus-like" structure, being formed of 9-14 single sensilla protruding from a common cuticular structure. Coeloconic sensilla were found in a very low number nearby each octopus-like cluster. At high magnification, s. basiconica and short s. trichodea showed a porous sensory cuticle, indicating an olfactory function.

Keywords: Cis boleti, antennal sensilla, morphology, Ciid beetle, scanning electron microscopy, insect olfaction, host discrimination, Trametes gibbosa, 1-octen-3-ol 


\subsection{Introduction}

Cis boleti (Scopoli 1763) (Coleoptera: Ciidae) is a fungivorous beetle, living in polyporous fungi and mining in fungal tissues for most of its life cycle (Lawrence 1973 and Hanski 1989). This Ciid beetle has a strong host preference to the genus Trametes (Fossli and Anderson 1998; Guevara et al. 2000; Thakeow et al. 2008), although other Ciid species are able to colonise several groups of bracket-fungi. The ecology of these beetles was investigated in regard to host preference and it was hypothesised that the chemical composition of fungal odours plays an important role (Jonsell and Nordlander 2004; Komonen and Kouki 2005). To address this question we previously investigated the volatile composition of the C. boleti host Trametes gibbosa (Basidiomycetes: Polyporaceae). Moreover, electrophysiological experiments performed with electroantennography (EAG) showed that the typical mushroom-like odour, 1-octen-3-ol, elicited strong antennal signals of $C$. boleti (Thakeow et al. 2008). When testing the pure volatiles in behavioural tests it was found that $C$. boleti is able to discriminate between the $(R)$ and $(S)$ enantiomers of 1-octen-3-ol, suggesting that these similar compounds may activate different pathways of the odour transduction. Up to now this enantiomeric discrimination was found in some insect species, either to specific configuration of pheromone components (Kozlov et al. 1996), or to key compounds of host volatiles (Ulland et al. 2006). Our results demonstrated that olfactory perception play an important role in host finding of $C$. boleti and most likely in the full family of Ciid beetles. However, no detailed examination of the chemosensory system of the antennae of the C. boleti was found in literature. In the attempt to find comparable data regarding the antennal morphology of other Ciid species, we did not find any description of the fine structure of the antennal morphology in species belonging to this family. Therefore, we decided to investigate for the first time the antennal morphology of $C$. boleti and the distribution of the different sensillar types. 


\subsection{Materials and methods}

\subsubsection{Insects}

Cis boleti beetles, colonising the wood rotting fungus Trametes gibbosa (Basidiomycete: Polyporaceae), were collected from Königsbuche, a natural forest protection area nearby Göttingen, Germany. The adults were collected from the fruiting bodies of Trametes gibbosa, classified taxonomically and sexed by looking at the characteristic setiferous patches, called setiferous fovea, which are present on the $1^{\text {st }}$ visible abdominal sternite of the males (Faustini and Halstead 1982).

\subsubsection{Scanning electron microscopy}

Ten intact male and female beetles were selected for scanning electron microscopy (SEM) examination. The specimens were first fixed in 50\% ethanol (Merck, Darmstadt, Germany) for 1 day. The animals were then cleaned in an ultrasonic bath for 2 min and subjected to dehydration in a graded ethanol series $(70,80,90$, and $96 \%$ ), by changing the alcohol concentration every day. The insects were then soaked in 98\% ethanol and liquid carbon dioxide was utilised for drying in a critical point dryer (Balzers CPD 030, Bal Tec AG, Fürstentum, Liechtenstein). Subsequently, the specimens were mounted on aluminium stubs with the ventral or the dorsal surface upwards and coated with gold in a sputter coater (Blazers SCD 050, Bal Tec AG, Fürstentum, Liechtenstein). Specimens were examined in a LEO SRV-32 scanning electron microscope (Electron Microscopy Ltd., Germany) at the Institut für Materialphysik, Georg-August University of Göttingen, Germany.

\subsubsection{Distribution of sensilla on the antennae}

The identification of the morphological sensillar structures was done according to Schneider (1964) and Keil (1999), adopting the nomenclature proposed for the insect 
sensilla by Altner (1977). The sensillar types were identified and counted on the microscope screen. Ventral surface sensilla as well as dorsal surface sensilla were mapped on all the antennal segments of both male and female adults. Because sensillar distributions were found to be identical in both sexes, data were pooled.

\subsection{Results}

\subsubsection{Gross morphology of the antenna}

The antenna of $C$. boleti is a classical clubbed or clavate antenna, formed by 10 antennomers where the last three are expanded and enlarged resembling a club. In Figure 5-1A, an SEM picture of the ventral view on the entire C. boleti antenna is displayed. Under a light microscope, the distal parts of all three antennomers look like a dense cover of sensilla. The antenna was measured under light microscopy and SEM and showed to be about $0.84 \pm 0.22 \mathrm{~mm}$ long. In several specimens, the antenna was protectively placed under the insect head and thorax as it is shown in Figure 5-1A. A representation of the original proportion of antennal shape is proposed in Figure 5-5, based on SEM images. The first antennal segment, or scape, is an expanded segment with an oblong form of circa $0.2 \mathrm{~mm}$ on its longitudinal diameter. The second antennal segment, or pedicel, has a spherical form of circa $70 \mu \mathrm{m}$, followed by an elongate third and fourth segment of circa 80 and $70 \mu \mathrm{m}$ of length, respectively. Segments five, six, and seven have a subspherical shape and are the smallest antennal segments of circa 40, 35 and $35 \mu \mathrm{m}$ of length, respectively. The last three segments are enlarged antennomers and contribute almost to the half of the length of the whole antenna. The eighth, the ninth and the tenth segments are circa $95 \times 85 \mu \mathrm{m}, 95 \times 90 \mu \mathrm{m}$ and $120 \times 90 \mu \mathrm{m}$ (length x width), respectively (Figure 5$1 \mathrm{~B}$ and Figure 5-5). No significant differences were found between males and females, although female antennae showed the tendency to be bigger than the male ones. 


\subsubsection{Morphological sensillar types}

Four morphological types of sensilla can be distinguished in the SEM pictures of the antennae of both male and female $C$. boleti beetles: two types of sensilla trichodea, sensilla basiconica and sensilla coeloconica.

\section{Sensilla trichodea}

The most abundant sensilla found along the antennomers of $C$. boleti in both male and female beetles are the sensilla trichodea (grooved peg surface) (Figure 5-2). There are two types of s. trichodea identified according to its length, long s. trichodea (LT) and short $s$. trichodea (ST). The long $s$. trichodea is a sharply pointed sensillum, which is inclined and slightly curving toward the apex of the segment, and therefore they are also referred as sensilla trichodea curvata according to Renthal et al. (2003). The length of this sensillar type is $54.7 \pm 5.5 \mu \mathrm{m}$ and the basal width is $2.82 \pm 0.55 \mu \mathrm{m}$. They are the longest sensillar type among the identified antennal sensilla of $C$. boleti. The short s. trichodea are $33.0 \pm 2.4 \mu \mathrm{m}$ in length and $1.84 \pm 0.20 \mu \mathrm{m}$ in basal width (Figure $2 \mathrm{~A}$ ). Their structure is similar to that of the long s. trichodea possessing a sharp point, but with a lower inclination toward their apex. At high magnification, the surface of both long and short trichoid sensilla showed small longitudinal ridges, and wall pores were seen as small rounded openings between the cuticular ridges (Figure 5-2B).

\section{Sensilla basiconica}

Rounded-tip s. basiconica on the antenna of $C$. boleti were found only arranged in clusters (Figure 5-3.) on each of the distal three antennomers. Each antennomer bears 4 clusters of basiconic sensilla on the lateral apical corners of each antennomer, nearby the junction with the other antennomer for the eighth and ninth antennomer and on the apex of the last antennomer. Each cluster strongly reassembled an "octopus-like" structure, being formed of 9-14 single sensilla protruding from a common cuticular structure. Therefore, these sensillar clusters were called octopus-like clusters. As shown in the dorsal and ventral view of the antenna representation there were totally 12 octopus-like clusters on each antenna (Figure 5-5). The s. basiconica present on each octopus-like cluster have an 
average length of $22.5 \mu \mathrm{m}$, with a relatively high variability in their length from 18 to 35 $\mu \mathrm{m}$. The calculated basal width was $3.04 \pm 0.32 \mu \mathrm{m}$. At high magnification, the surface of the s. basiconica was smooth and covered with irregular dense wall-pores detected in a large number all over the sensillar cuticle, with the exception of the basal part. By SEM the diameter of the pores was estimated as approximately $30 \mathrm{~nm}$ and the pore density as $\leq 20$ pores $/ \mu \mathrm{m}^{2}$.
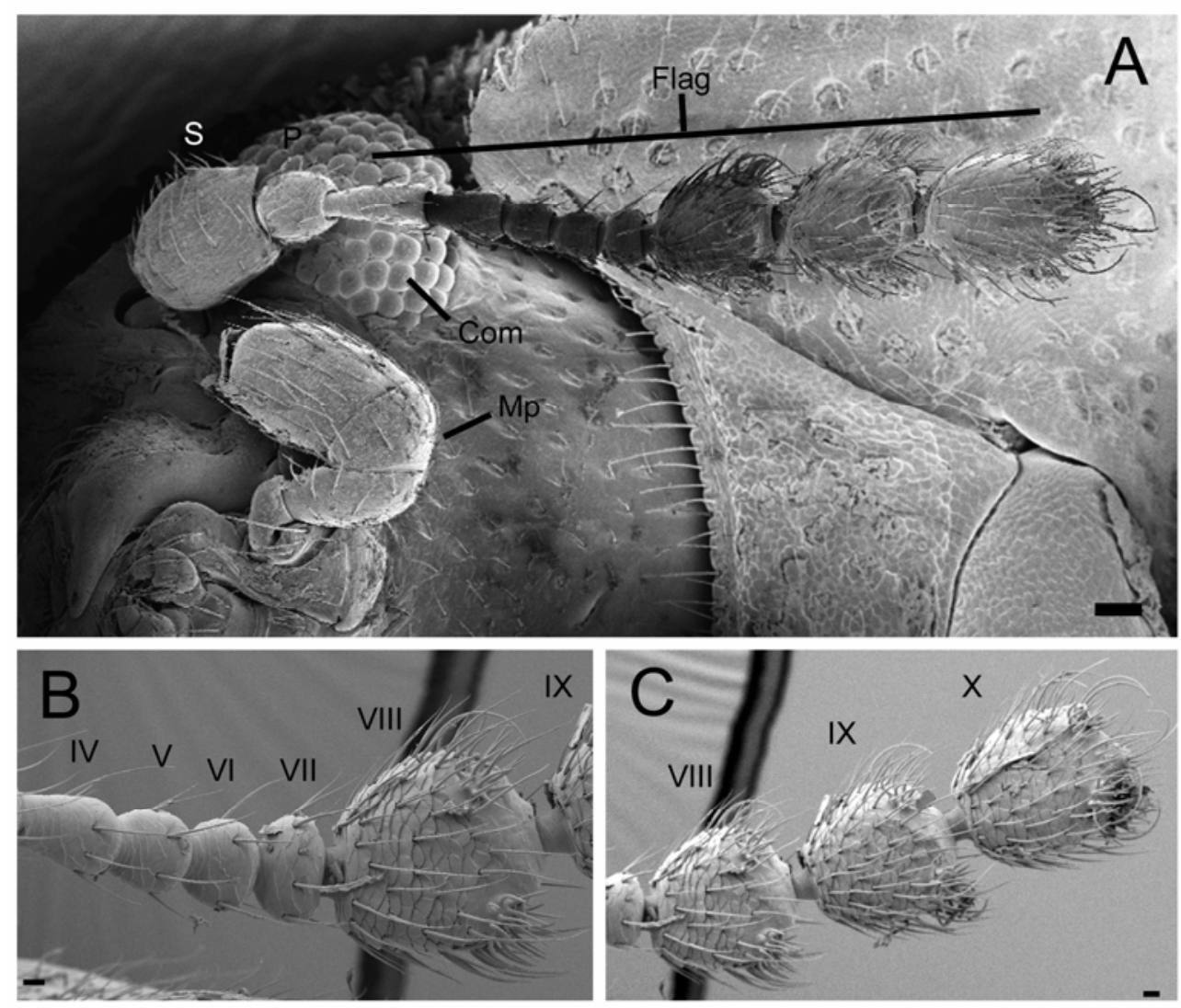

Figure 5-1 Scanning electron micrographs of the antenna of a Cis boleti (Ciidae) dult. A: general overview of the ventral anterior part of the insect showing the entire left antenna. Com: Compound eye; Flag: flagellum; Mp: maxillary palp; S: scape; P: pedicel. B and C: Parts of segments of the flagellum. IV: $4^{\text {th }}$ antennomer, V: $5^{\text {th }}$ antennomer, VI: $6^{\text {th }}$ antennomer, VII: $7^{\text {th }}$ antennomer, VIII: $8^{\text {th }}$ antennomer, IX: $9^{\text {th }}$ antennomer, IX: $10^{\text {th }}$ antennomer. Bar in $\mathrm{A}=30 \mu \mathrm{m}$. Bar in $\mathrm{B}$ and $\mathrm{C}=10 \mu \mathrm{m}$. 


\section{Sensilla coeloconica}

This sensillum type showed a low abundance on all antennomers. They were found only nearby octopus-like clusters, in number of one to three, generally in a lateral or proximal position (Figure 5-4A). The length of this sensillar type is $7.4 \pm 0.20 \mu \mathrm{m}$ and $1.82 \pm 0.52 \mu \mathrm{m}$ in basal width. The sensilla look similar to a morel mushroom (Figure 5-4B), which contain two structures: the upper part similar to a grooved peg with longitudinal ridges and the lower part with a smooth surface. Whether this type of sensilla had pores on its wall was not demonstrated in our study,

\subsubsection{Distribution of the sensillar types}

Sensilla distribution was measure all over the antennal surface, although more examinations were done over the last three antennal segments, since they bear a diversity of dense sensilla, their surface is larger then any other segments and strongly contribute to the odour coding of the species. No significant difference between males and females was observed in the density of any type of sensilla.

Short s. trichodea were regularly distributed on all the antennomers with increasing frequency on the last three antennomers. By counting on the microscope screen the numbers of sensilla on the ventral and dorsal surface of the antenna was determined to be approximately 60, 80, and 100 of the short s. trichodea for antennomer 8, 9, and 10, respectively.

Long s. trichodea were present only on the last three antennomers, occurring on the upper part of each antennomer, surrounding each octopus-like cluster. Often some of these long curved pegs were found to cover the octopus-like clusters as it visible in Figure $5-2 \mathrm{C}$.

S. basiconica were arranged in clusters in the position described above as illustrated in Figure 5-5. No other basiconic sensilla were found on the entire surface of the antenna. 

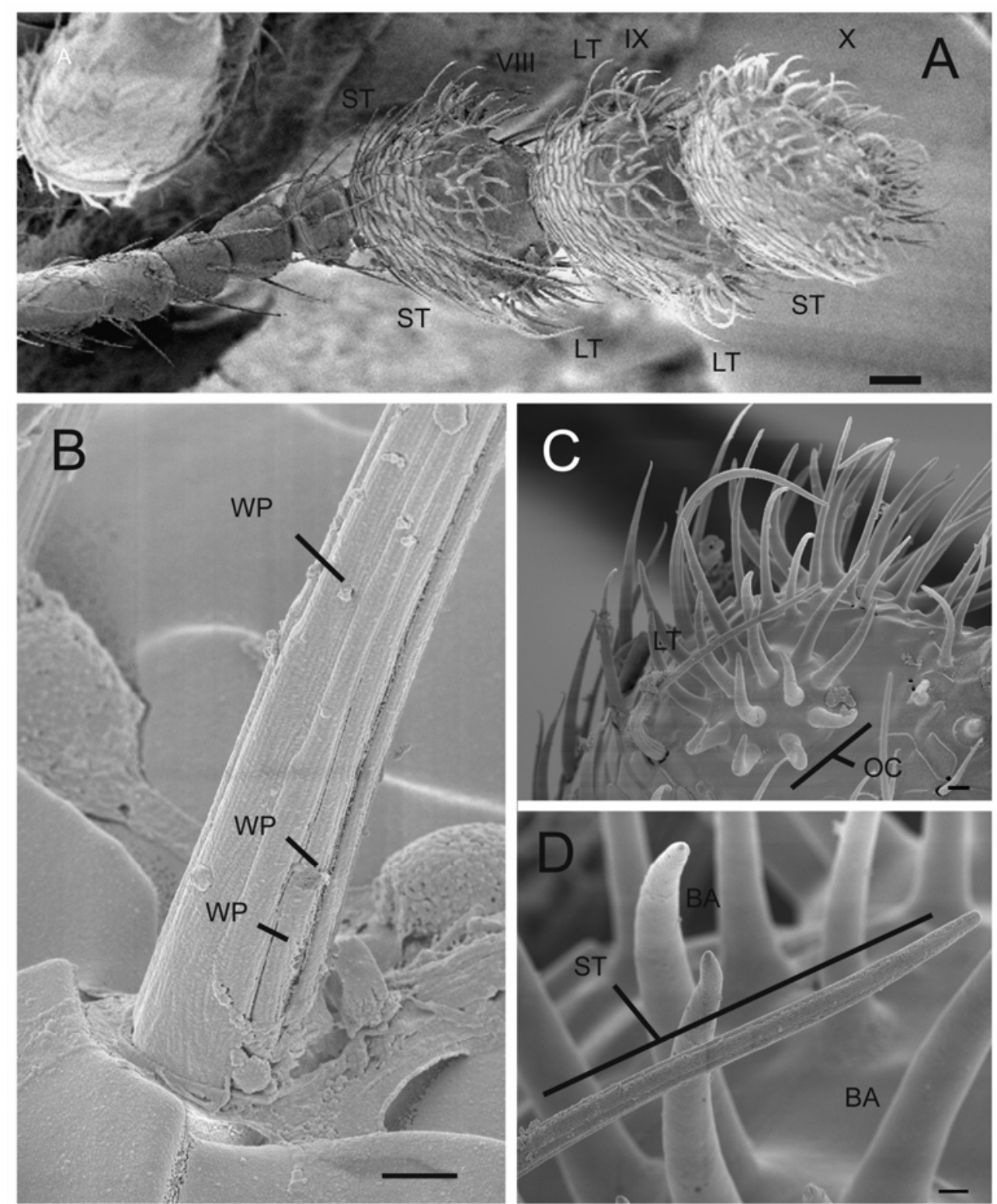

Figure 5-2 Sensilla trichodea. Scanning electron micrographs displaying A: the sensillar distribution on the last segments of Cis boleti antenna. ST: short s. trichodea; LT: long $s$. trichodea. B: basal part of a short sensillum trichodeum. WP: wall pores on the sensillar surface. C: sensilla on the apical part of the $9^{\text {th }}$ segment showing a octopus cluster (OC) surrounded by the long sensilla trichodea (LT). D: high magnification of the terminal part of a long sensillum trichodeum (LT) showing the small longitudinal ridges on the surface. BA: basiconic sensillum. Bar in $\mathrm{A}=20 \mu \mathrm{m}$, in $\mathrm{B}=1 \mu \mathrm{m}$, in $\mathrm{C}=3 \mu \mathrm{m}$, and $\mathrm{D}=1 \mu \mathrm{m}$. 

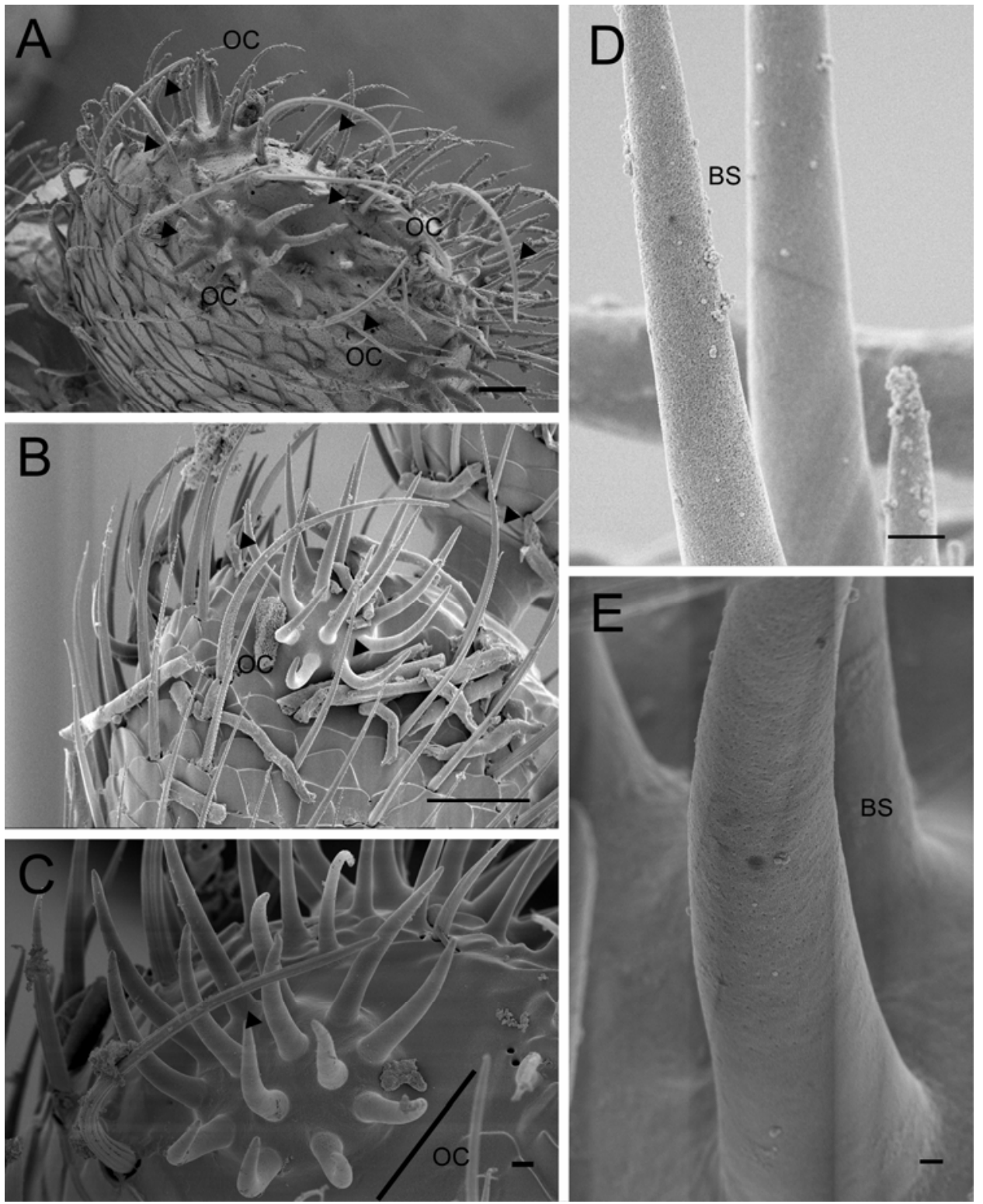

Figure 5-3 Sensilla basiconica. Scanning electron micrographs displaying the octopus-like clusters. Each cluster is formed by $9-14$ basiconic sensilla. A: antennal apex showing the 4 octopus-like clusters (OC) on the distal part. B: distal part of the $9^{\text {th }}$ antennomer showing one octopus-like cluster. C: distal part of the $8^{\text {th }}$ antennomer showing one octopus-like cluster. D and E: high magnification of basiconic sensilla showing dense pores on the external wall surface. Bar in $A$ and in $B=10 \mu \mathrm{m}$, in $C$ and $D=1 \mu \mathrm{m}$, and in $\mathrm{E}=300 \mathrm{~nm}$. 
S. coeloconica were the less abundant sensilla, being present in few units on the upper part of the last three antennomers above or nearby each octopus-like cluster. However, it was difficult to number all the coeloconic sensilla, since they are relatively short and often hidden behind other sensillar types.
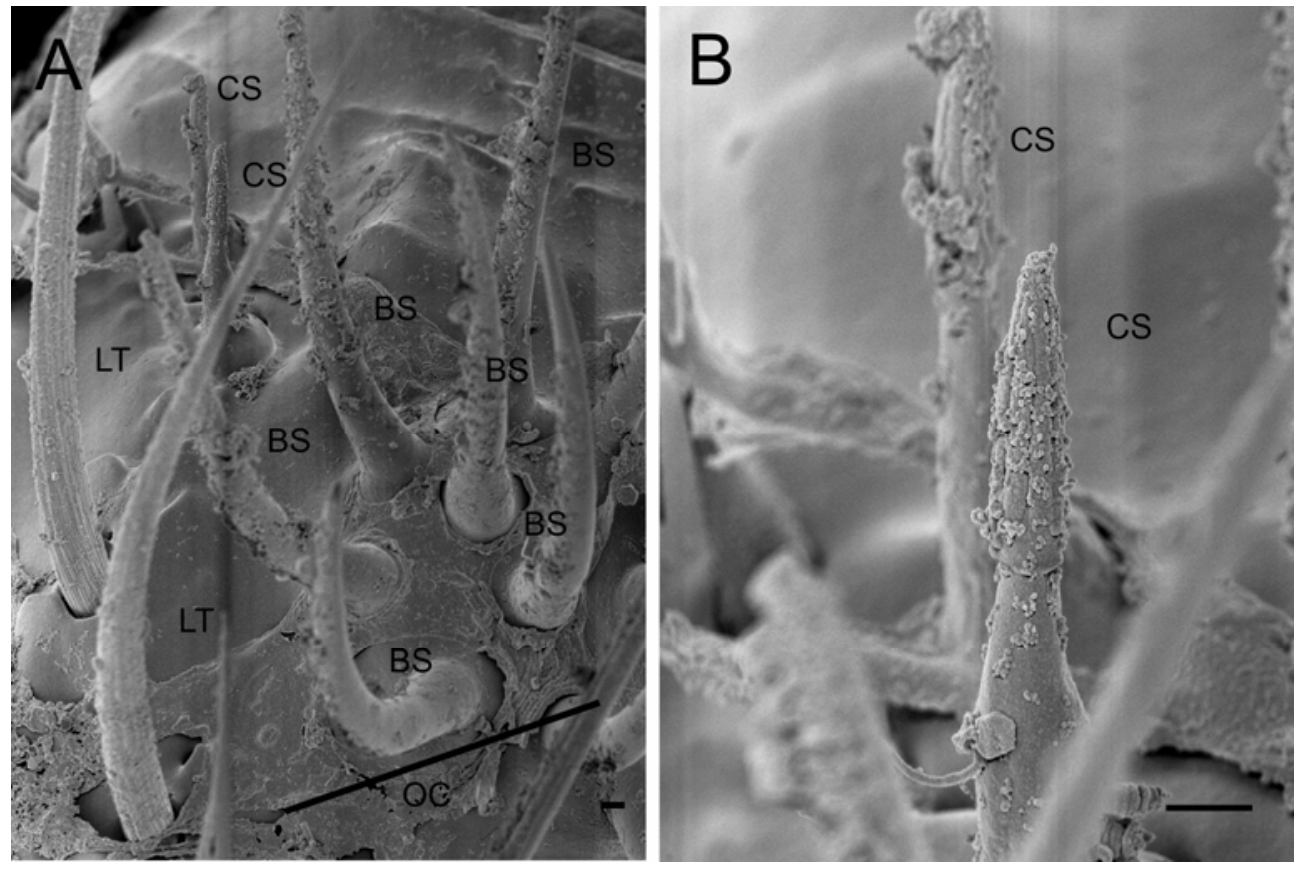

Figure 5-4 Sensilla coeloconica. Scanning electron micrographs displaying (A) the distal part of the $9^{\text {th }}$ antennomer, (B) the high magnification of the 2 coeloconic sensilla located nearby octopus-like cluster. BS: basiconic sensilla; CS: coeloconic sensilla; LT: long trichodea sensilla; $\mathrm{OC}$ : octopus-like cluster. Bar in A and in $\mathrm{B}=1 \mu \mathrm{m}$. 


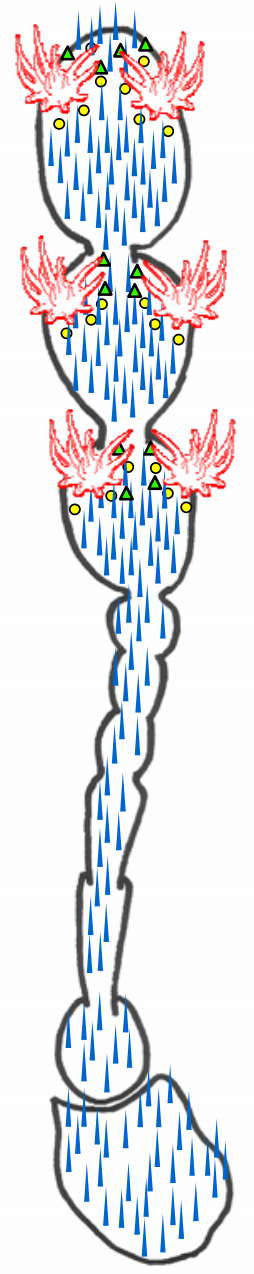

dorsal

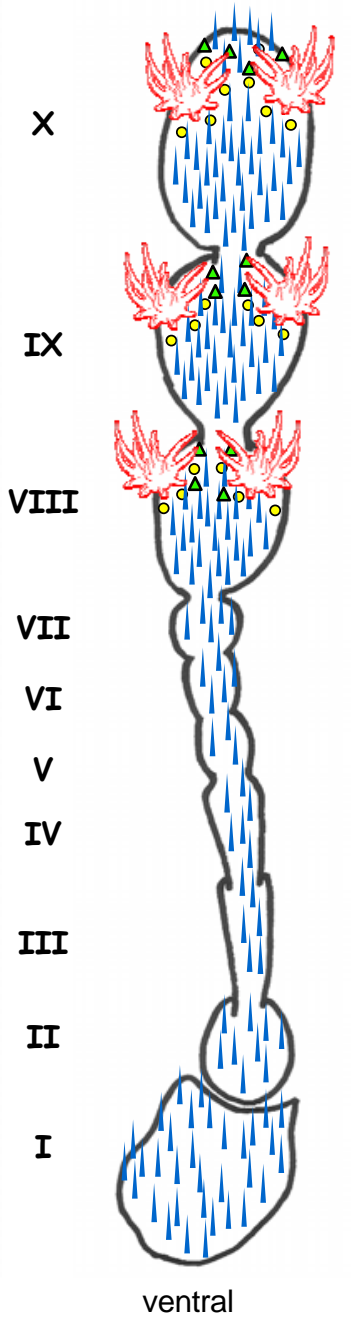

Figure 5-5 Map representation of the distribution of four sensillar morphological categories found on the antennal surface of the adult of Cis boleti (Coleoptera: Ciidae): short trichoid sensilla, long trichoid sensilla, coeloconic sensilla and octopus clusters formed by 9-14 basiconic sensilla. . The distribution of the different sensilla was intended to reflect the real distribution on the antenna, e.g. the high concentration of figures reflects the high concentration on the antenna. Antennal form represents the direct proportion and shape among the different segments, where the entire antenna is approximately $840 \mu \mathrm{m}$ long. 


\subsection{Discussion}

Here we report the first morphological investigation of $C$. boleti antenna. Prior to this study, no report on morphological structure of the adults of $C$. boleti antennal sensory organ has been done, to our knowledge. An investigation was performed on the sensory organs of the antennae and mouthparts of the larvae of $C$. boleti, in a comparative study of larval sensory organs of several beetle species (Alekseev et al. 2006). However, the larval sensilla are morphologically and functionally very different from the adult sensilla, therefore, no comparison is possible between our study and this previous one. According to a recent phylogenetic study among Coleoptera, the Ciidae belong to the Tenebrionoidea superfamily (Hunt et al. 2007). Therefore, we decided to compare C. boleti antennal structure with the one on Tribolium castaneum (Coleoptera: Tenebrionidae), which has a similar gross antennal morphology and a comparable body size. In the antenna of adult $T$. castaneum only two types of sensilla were described: s. trichodea and s. basiconica, both supposed to mediate olfactory signals (Roth and Willis 1951). The distribution of the $s$. trichodea of $T$. castaneum was comparable with the one found for the short s. trichodea of $C$. boleti. Interestingly, the basiconic sensilla of $T$. castaneum were also found to be restricted to the apical ends of the club segments, although in this case they were arranged in a ring around a dense patch of slender trichoid sensilla. Coeloconic sensilla of the antenna of $C$. boleti were very rare and no wall-pores were visible. In other insect species it is believed they have olfactory function (Steinbrecht 1999; Keil 1999), or they are considered as hygro- and thermoreceptors (Roux et al. 2005).

The most peculiar sensillar structures of $C$. boleti antenna are the octopus-like clusters. These multi-sensillar plaques of basiconic sensilla have never been discovered before, to the best of our knowledge. The basiconic sensilla of $C$. boleti are likely comparable with the basiconic sensilla of $T$. castaneum, since they share similar topographic distribution (but the latter ones are not organised in clusters) and have a similar external morphology. The number and the position of these sensilla were found to vary among different species of Tribolium. In some cases two or three basiconic sensilla were found to diverge or to branch from the same cuticle structure, in analogy of our finding in C. boleti (Roth and Willis 
1951). There is a high diversification in coleopteran species, but we suggested that basiconic sensilla of $T$. castaneum and $C$. boleti may have a similar specialise function in odour coding. In other groups of insects, as for example in Lepidoptera, it has been reported that long trichoid sensilla respond to the insect's pheromone rather to plant odour, while basiconic sensilla respond to the so-called general odours or green volatiles (Steinbrecht et al. 1996). C. boleti is not know to produce pheromones, but the presence only in the males of a gland setiferous organ on the $1^{\text {st }}$ visible abdominal sternite may indicate that sex pheromones are secreted (Faustini and Halstead 1982). On the other hand, the lack of differences between the sense organs of males and female negate the possibility that the trichoid sensilla may act as sex-pheromone receptors. Determining which sensillar types are used by $C$. boleti to code host fungivorous volatiles, like the highly attractive 1-octen-3-ol, and pheromone components will require further electrophysiological research.

\section{Acknowledgement}

This experiment was carried out with kind help of Mr. Matthias Hahn, Institut für Materialphysik and Johann-Friedrich-Blumenbach-Institut für Zoologie \& Anthropologie, Georg-August University of Göttingen.

\subsection{References}

Alekseev MA, Sinitsina EE, Chaika SY. 2006. Sensory organs of the antennae and mouthparts of beetle larvae (Coleoptera). Entomological Review 86: 638-648.

Altner H. 1977. Insect sensillum specificity and structure: an approach to a new typology. In Olfaction and Taste VI. LeMagnen J, McLeod P. (Eds). Information Retrieval, Washington. pp. 295-303.

Faustini DL, Halstead DGH. 1982. Setiferous structures of male Coleoptera. Journal of Morphology 173: 43-72.

Fossli TE, Andersen J. 1998. Host preference of Cisidae (Coleoptera) on tree-inhabiting fungi in northern Norway. Entomologica Fennica 9: 65-78.

Guevara R, Rayner ADM, Reynolds S. 2000. Orientation of specialist and generalist fungivorous Ciid beetles to host and non-host odours. Physiological Entomology 25: 288295. 
Hanski I. 1989. Fungivory: fungi, insects and ecology. In: Wilding N, Collins NM, Hammond PM, Webber JF. (Eds). Insect-fungus interactions. Academic Press, London: pp. 25-68.

Hunt T, Bergsten J, Levkanicova Z., Papadopoulou A, St John O, Wild R, Hammond PM, Ahrens D, Balke M, Caterino MS, Gómez-Zurita J, Ribera I, Barraclough TG, Bocakova M, Bocak L, Vogler AP. 2007. A comprehensive phylogeny of beetles reveals the evolutionary origins of a super-radiation. Science 318: 1913-1916.

Jonsell M, Nordlander G. 2004. Host selection patterns in insects breeding in bracket fungi. Ecological Entomology 29: 697-705.

Keil TA. 1999. Morphology and development of the peripheral olfactory organs. In: Insect olfaction. Hansson BS. (Ed). Berlin Springer-Verlag. pp. 5-47.

Komonen A. Kouki J. 2005. Occurrence and abundance of fungus-dwelling beetles (Ciidae) in boreal forests and clearcuts: habitat associations at two spatial scales. Animal Biodiversity and Conservation 28: 137-147.

Kozlov MV, Zhu J, Philipp P, Francke W, Zvereva EL, Hansson BS, Löfstedt C. 1996. Pheromone specificity in Eriocrania semipurpurella (Stephens) and E. sangii (Wood) (Lepidoptera: Eriocraniidae) based on chirality of semiochemicals. Journal of Chemical Ecology 22: 431-454.

Lawrence JF. 1973. Host preference in Ciid beetles (Coleoptera: Ciidae) inhabiting the fruiting body of Basidiomycetes in North America. Bulletin Museum of Comparative Zoology at Harvard College 145: 163-212.

Renthal R, Velásquez D, Olmos D, Hampton J, Wergin WP. 2003. Structure and distribution of antennal sensilla of the red imported fire ant. Micron 34: 405-13.

Roth LM, Willis ER. 1951. Hygroreceptors in adults of Tribolium (Coleoptera, Tenebrionidae). Journal of Experimental Zoology 116: 527-570.

Roux O, van Baaren J, Gers C, Arvanitakis L, Legal L. 2005. Antennal structure and oviposition behaviour of the Plutella xylostella specialist parasitoid Cotesia plutellae. Microscopy Research and Technique 68: 36-44.

Schneider D. 1964. Insect antennae. Annual Review of Entomology 9: 103-122.

Steinbrecht RA. 1996. Structure and function of insect olfactory sensilla. In: Olfaction in mosquito-host interactions. Bock GR, Cardew G. (Eds). Wiley, Chichester. pp 158-177.

Steinbrecht RA. 1999. Olfactory receptors. In: Atlas of arthropod sensory receptors-Dynamic morphology in relation to function. Eguchi E, Tominaga Y. (Eds). Springer-Verlag, Tokyo. pp. 155-176.

Thakeow P, Angeli, S, Weißbecker B, Schütz S. 2008. Antennal and behavioural responses of Cis boleti to fungal odour of Trametes gibbosa. Chemical Senses 33: 379-387.

Ulland S, Ian E, Borg-Karlson A-K, Mustaparta H. 2006. Discrimination between enantiomers of linalool by olfactory receptor neurons in the cabbage moth Mamestra brassicae (L.). Chemical Senses 31: 325-334. 


\section{CHAPTER 6}

\section{Antennal and Behavioural Responses of Cis boleti to Fungal Odour of Trametes gibbosa}

Prodpran Thakeow, Sergio Angeli, Bernhard Weißbecker, and Stefan Schütz

Thakeow P, Angeli S, Weißbecker B, Schütz S. 2008. Antennal and Behavioural Responses of Cis boleti to Fungal Odour of Trametes gibbosa. Chemical Senses 33: 379-387.

Contributions to this paper: I performed the experiments and prepared the manuscript for which I am the corresponding author. 



\subsection{Abstract}

Cis boleti (Coleoptera: Ciidae), preferentially colonises fungi from the genus Trametes that are known as important wood decomposers. The aim of our research was to investigate if C. boleti uses the chemical volatile composition of its fungal host, Trametes gibbosa, as a key attraction factor. Therefore, the $T$. gibbosa fruiting body volatiles were analysed by using gas chromatography-mass spectrometry (GC-MS), with parallel electroantennographic detection (GC-EAD) using adults of $C$. boleti. Furthermore, we examined the behavioural responses of $C$. boleti to the $T$. gibbosa volatile compounds. The dominant component of the T. gibbosa fruiting body bouquet was 1-octen-3-ol. Other volatiles, like the aldehydes hexanal, nonanal and (E,E)-2,4-decadienal and the terpene $a$-bisabolol were present in minor quantities. 1-Octen-3-ol was released with a ratio of the $(R)$ and $(S)$ enantiomers of 93:7, respectively. Electroantennography employing C. boleti antennae yielded consistently dominant responses to 1-octen-3-ol. GC-EAD and EAG responses to pure standard compounds showed that C. boleti also perceived other host-fungal volatiles. A highly significant attraction to 1-octen-3-ol was observed in behavioural tests. Female beetles were significantly attracted to the $(S)-(+)$ enantiomer at ten times lower doses than male beetles. Our finding is the first direct proof that Ciid beetles use 1-octen-3-ol as a key cue for host finding.

Keywords: fungivorous insect, VOCs, host selection, GC-MS/EAD, (S)-(+)-1-octen-3-ol, EAG 


\subsection{Introduction}

Wood-rotting fungi, like bracket fungi, are known to release a wide range of volatile organic compounds (VOCs) such as alcohols, aldehydes, esters, ketones, acids and terpenoids (Gross et al. 1989; Fäldt et al. 1999; Rösecke et al. 2000; Rösecke and König 2000; Ewen et al. 2004; Thakeow et al. 2006; Ziegenbein et al. 2006). Two important features of these fungal volatile patterns are the group of 8-carbon aliphatic compounds (C8-compounds) and the group of terpenoids (Fäldt et al. 1999; Thakeow et al. 2007). The C8-compounds as octanols, octenols and octanones are common and contribute to the typical fungal odour (Tressl et al. 1982; Wurzenberger and Grosch 1982; Gross et al. 1989). Especially 1-octen-3-ol, known also as mushroom alcohol, is the most characteristic fungal volatile, being used as aroma in several food industries (Hadar and Dosoretz 1991). The pattern of VOCs released by fungi is often species-specific (Wheatley 2002). However, recent analyses showed that VOC pattern may be affected considerably by the developmental stage and/or the type of fungal substrate (Wheatley et al. 1997, Zeppa et al. 2004, Thakeow et al. 2007). Fungi of the genus Trametes (Basidiomycetes) are growing on different substrates as the trunks of dead trees, stored wood logs and construction wood causing considerable economic losses (Zabel and Morrell 1992). On the other side these fungi are ecologically important as major organisms decomposing biomass in forests (Boddy 1991; Boddy and Watkinson 1995).

Ciid beetles belong to the family Ciidae (Coleoptera) and are a group of fungivorous insects which colonise bracket fungi (Basidiomycetes: Polyporaceae) (Hanski 1989). Most Ciid beetles are smaller than $3 \mathrm{~mm}$ and host specificity ranges from monophagous to polyphagous. For example, Cis bilamellatus has no host preference among bracket fungi, while Cis nitidus is specialised to Ganoderma adspersum (Guevara et al. 2000a). Cis boleti is oligophagous, its host range is restricted to the genus Trametes (Fossli and Andersen 1998; Guevara et al. 2000a), and it is often found associated to Trametes gibbosa and Trametes versicolor in the German beech forests. To the best of our knowledge there are no direct evidences of which chemicals are perceived for host selection of Ciid beetles, although it has been hypothesised that the chemical composition of fungal volatiles plays an 
important role (Jonsell and Nordlander 1995, 2004; Guevara et al. 2000a, 2000b, 2000c; Komonen and Kouki 2005).

To find out whether fungal volatiles play a role in host selection of Ciid beetles, we characterised the fungal volatiles of Trametes gibbosa using gas chromatography-mass spectrometry (GC-MS), verified the antennal responses by gas chromatographyelectroantennographic detection (GC-EAD) and performed behavioural tests for host selection of Cis boleti.

\subsection{Materials and methods}

\subsubsection{Collection of fungi and insects}

Fruiting bodies of Trametes gibbosa (Pers.) Fr., growing on decayed beech (Fagus sylvatica) were collected from a natural forest protection area close to Göttingen (Germany), called Königsbuche. The fruiting bodies were stored in a cool, dark room at $10^{\circ} \mathrm{C}$ throughout the experiments. In order to prevent desiccation, the fruiting bodies were sprayed with tap water every week. Adults of Cis boleti were taken directly from the T. gibbosa fruiting bodies, sexed and used for all experiments.

\subsubsection{Extraction of $T$. gibbosa volatiles}

In order to obtain a sufficient sample of volatile compounds from the T. gibbosa fruiting bodies we performed a Soxhlet extraction. Twelve grams of T. gibbosa fruiting bodies were cut into small pieces and were put in an extraction thimble. Soxhlet extraction was carried out using a conventional system consisting of $250 \mathrm{ml}$ round bottom flask. The extraction was done with $150 \mathrm{ml}$ dichloromethane (GC-grade, Merck, Darmstadt, Germany) for $6 \mathrm{~h}$ at the solvent reflux temperature. The original extract was reduced to $2.0 \mathrm{ml}$ on a rotary evaporator at $40^{\circ} \mathrm{C}$ and standard atmosphere. The final extract was stored at $-80^{\circ} \mathrm{C}$, and 
used for T. gibbosa volatile identification as well as for the physiological and behavioural tests of C. boleti.

\subsubsection{T. gibbosa headspace analysis and emission rate of 1-octen-3-ol}

In order to investigate the headspace constitution of the $T$. gibbosa bouquet we decided to collect the fungal headspace volatiles using prepacked Tenax ${ }^{\circledR}$-TA type adsorbent tubes (Gerstel, Mülheim an der Ruhr, Germany, art. 012260-005-00). The adsorbents (60/80 mesh) have a surface area of $35 \mathrm{~m}^{2} \mathrm{~g}^{-1}$, and a density of $0.25 \mathrm{~g} \mathrm{ml}^{-1}$. The dimension of adsorbent bed is $60 \mathrm{~mm}$ in length and $4 \mathrm{~mm}$ in diameter. The sampling was carried out for 30 min using close loop stripping technique with a flow rate of $160 \mathrm{ml} \mathrm{min}{ }^{-1}$. Each sample, approximately $1 \mathrm{~cm}^{3}$ of fruiting body, was placed in a 250-ml PTFE bottle. We tested 2 samples of minimally $(<10 \%)$ and 3 samples of fully $(\sim 100 \%)$ colonised $T$. gibbosa fruiting bodies. The sampling was started after each sample was placed in the PTFE bottle for 10 min. The headspace volatiles were then analyzed by means of gas chromatography and mass spectrometry (GC-MS). After the headspace sampling was done, we dried the fruiting bodies in an oven at $105^{\circ} \mathrm{C}$ till a constant weight was obtained. The emission rate of 1-octen-3-ol was calculated by considering the quantity of released compound and expressed per mass of dried fruiting body and time (ng $\left.\mathrm{g}^{-1} \mathrm{~h}^{-1}\right)$.

\subsubsection{Chemicals}

1-pentanol (99\%, Aldrich, Steinheim, Germany), 1-hexanol (99\%, Aldrich, Steinheim, Germany), 3-octanol (>97\%, VWR, Darmstadt, Germany), (E)-2-octen-1-ol (97\%, Merck, Darmstadt, Germany), 1-octanol (98\%, Aldrich, Steinheim, Germany), 1-octen-3-ol (>98\%, Merck, Darmstadt, Germany), (S)-(+)-1-octen-3-ol (99.8\%, ACROS, Geel, Belgium), (R)-(-)-1-octen-3-ol (99\%, ACROS, Geel, Belgium), 3-octanone (>96\%, VWR, Darmstadt, Germany), hexanal (98\%, Aldrich, Steinheim, Germany), heptanal (95\%, ACROS, Geel, Belgium), (E)-2-heptenal (97\%, Aldrich, Steinheim, Germany), nonanal (>98\%, Merck, Darmstadt, Germany), (E,E)-2,4-heptadienal (90\%, Aldrich, Steinheim, 
Germany), (E,E)-2,4-decadienal (90\%, APCR, Karlsruhe. Germany), acetic acid (>99.8\%, Fluka, Buchs, Switzerland), propanoic acid (>99.5\%, Aldrich, Steinheim, Germany), butanoic acid (99\%, ABCR, Karlsruhe. Germany), hexanoic acid (98\%, Merck, Darmstadt, Germany), octanoic acid (>99\%, Merck, Darmstadt, Germany), $a$-bisabolol ( $>85 \%$, Fluka, Buchs, Switzerland), 2-pentyl furan (98\%, ABCR, Karlsruhe. Germany) and 2-methyl phenol (>99\%, Aldrich, Steinheim, Germany)

\subsubsection{GC-MS analysis}

A gas chromatograph $(6890 \mathrm{~N}$, Agilent Technologies, Paolo Alto, USA) coupled to a mass spectrometer (5973, Agilent Technologies, Paolo Alto, USA) was used for analysing the constituents in the extract and the headspace VOCs of T. gibbosa. Two column types, HP5MS (Non-polar column, Agilent Technologies, Paolo Alto, USA), 30 m x 0.25 mm i.d., $0.25 \mu \mathrm{m}$ film thickness and INNOWAX (Polar column, Agilent Technologies, Paolo Alto, USA), $30 \mathrm{~m} \times 0.25 \mathrm{~mm}$ i.d., $0.25 \mu \mathrm{m}$ film thickness were used in order to validate the composition of the samples. The extract was injected in a quantity of $1 \mu \mathrm{l}$ into the injector in the pulsed splitless mode at a temperature of $250^{\circ} \mathrm{C}$. Helium was used as a carrier gas at a flow rate of $1.0 \mathrm{ml} \mathrm{min}{ }^{-1}$. The oven temperature for the extract sample was programmed for an initial temperature of $50^{\circ} \mathrm{C}$, held for $1.5 \mathrm{~min}$, heated at a rate of $6.5^{\circ} \mathrm{C} \mathrm{min}-1$ to $250^{\circ} \mathrm{C}$ and held for $10.0 \mathrm{~min}$ at $250^{\circ} \mathrm{C}$. The operating conditions of GC-MS for analysing the Tenax ${ }^{\circledR}$-headspace samples were as follows. A thermodesorption system with a cold injection system (TDS-CIS, Gerstel, Mülheim an der Ruhr, Germany) was used. The tubes were heated up to $280^{\circ} \mathrm{C}$ in order to desorb the VOCs. The temperature program started at $40^{\circ} \mathrm{C}$, held for $3 \mathrm{~min}$, heated at a rate of $7.5^{\circ} \mathrm{C} \mathrm{min}^{-1}$ to $200^{\circ} \mathrm{C}$, and held for $5 \mathrm{~min}$ at

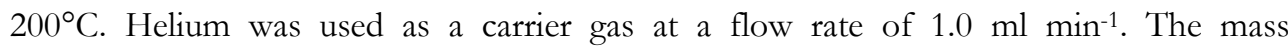
spectrometer was operated in the scan mode in a range of 20-400 amu, a source temperature of $230^{\circ} \mathrm{C}$ and EI mode at $70 \mathrm{eV}$. 


\subsubsection{Identification and quantification of $T$. gibbosa volatiles}

The chromatograms were preliminary interpreted with Enhanced chemstation version D00.00.38 (Agilent Technologies, Paolo Alto, USA), the Mass Spectral Search library of the National Institute of Standards and Technology (NIST, Gaithersburg, USA), and the Massfinder version 3.0 software together with the library 'Terpenoids and Related Constituents of Essential Oils' (Hochmuth, König, Joulain, Hamburg, Germany). The interpretation was confirmed by matching the mass spectra and retention times with those of authentic standards on the two different columns used. Linear retention indices were calculated for each identified volatile using the retention times of $n$-alkane series (from $\mathrm{C}_{10}$ till $\mathrm{C}_{23}$ ) as reference compounds, applying the linear equation developed by Van den Dool and Kratz (1963). The quantification of 1-octen-3-ol was done by five-point calibration of the standard compound and evaluation of peak areas in the selected ion monitoring mode. Moreover, quantification of the volatile compounds was performed by passing the $T$. gibbosa extract on a gas chromatograph and a flame ionisation detector (GC-FID; Agilent Technologies, Paolo Alto, USA) using 1-octen-3-ol as an internal standard.

The enantiomer identification of 1-octen-3-ol of the T. gibbosa extract was done in cooperation with Dr. Holm Frauendorf (Institute of Organic and Molecular Chemistry, Faculty of Organic Chemistry, Göttingen University) by performing enantioselective gas chromatography on a Carlo Erba Instrument, HRGC 5300 Mega Series (Milan, Italy). The instrument was equipped with a $25 \mathrm{~m} \times 0.25 \mathrm{~mm}$ i.d. column coated with Heptakis (2,3-diO-acetyl-6-O-TBDMS)- $\beta$-cyclodextrin (50\% in OV1701) (Prof. König, Hamburg, Germany). The injector (split/splitless) and FID were operated at 220 and $240^{\circ} \mathrm{C}$, respectively. The experiment was run isothermally at $80^{\circ} \mathrm{C}$. Two standards of rac-1-octen3-ol and $(S)-(+)-1$-octen-3-ol were used. 


\subsubsection{Electrophysiological measurements}

The electrophysiological analyses were carried out with gas chromatograph-mass spectrometer/electroantennographic detector (GC-MS/EAD), as described in Weissbecker et al. (2004). The insect antenna was dissected and placed in an antenna holder (Prof. Koch, Kaiserslautern, Germany) (Färbert et al. 1997), where both ends of the antenna were immersed in an adapted-insect-hemolymph electrolyte solution (Kaissling and Thorson 1980). The antennal activity of 10 males and 10 females of C. boleti adults was recorded. As the antennae of $C$. boleti adults are quite small (0.7-1 mm long), each excised antenna was mounted on antenna holder using a piece of filter paper to make sure the contact with the electrolyte solutions was effective. This experiment was done by injecting $1 \mu$ l of $T$. gibbosa extract on an HP 6890N GC equipped with INNOWAX column, with the same parameters as for GC-MS analyses. The EAD was carried out under humidified air at room temperature with a flow rate at $201 \mathrm{~h}^{-1}$.

Electroantennography (EAG) was employed to confirm the responsiveness of the antennae to $10^{-3}$ dilution in paraffin oil (Uvasol ${ }^{\circledR}$, Merck, Darmstadt, Germany) of the following chemicals:1-pentanol, 1-hexanol, 3-octanol, (E)-2-octen-1-ol, 1-octanol, 1octen-3-ol, 3-octanone, hexanal, heptanal, (E)-2-heptenal, octanal, (E)-2-octenal, nonanal, (E,E)-2,4-heptadienal, (E,E)-2,4-decadienal, acetic acid, propanoic acid, butanoic acid, hexanoic acid, octanoic acid, $a$-bisabolol, 2-pentyl furan and 2-methyl phenol. For the two enantiomers of 1 -octen-3-ol, we performed a dilution series from $10^{-6}$ to $10^{-3}$ in order to obtain a dose-response curve. Small pieces of filter paper $\left(2 \mathrm{~cm}^{2}\right.$; Schleicher \& Schuell, Dassel, Germany) were soaked with $100 \mu$ of the standard dilution or paraffin oil only (control). The filter paper was inserted into a $10 \mathrm{ml}$ glass syringe (Poulten \& Graf GmbH, Wertheim, Germany). A reproducible stimulus was supplied by puffing $5 \mathrm{ml}$ of air over the antenna (Schütz et al. 1999). The EAG response of the antennae was recorded for each standard dilution from at least five male and five female beetles. The response to paraffin oil was considered as negative control and was subtracted from all the reported EAG measurements. 


\subsubsection{Behavioural tests}

Behavioural investigations were done by using a dual choice bioassay. The setup consisted of a closed Petri dish (13 cm diameter) used as an arena. A filter paper $\left(1.5 \mathrm{~cm}^{2}\right)$ treated with the tested sample (as T. gibbosa fruiting body extract or 1-octen-3-ol) was placed in a side part of the Petri dish (1 cm from the border) and a control filter paper treated with paraffin oil as control was placed in the opposite side. In a typical experiment, ten animals of the same sex were placed in the middle of the Petri dish and were allowed to walk for $15 \mathrm{~min}$ in the darkness. The number of beetles was then counted, regarding to the test compound area, the neutral area (a central segment of $2 \mathrm{~cm}$ ) and in the control area. Two indices were calculated: the activity index $\left(A_{c} I\right)$ as the number of active animals ( $=$ total number of beetles placed in the arena minus the beetles in the neutral area) divided by the total number of beetles placed in the arena and the attraction index $\left(A_{t} I\right)$ as the number of beetles found in the test compound area divided by the number of active

animals. The significance of the results was statistically evaluated by an analysis of variance (ANOVA) using Statistica 7 (2004) (Statsoft Inc., Tulsa, USA).

We performed different bioassays with this setup. Experiment 1: This experiment was done in order to ensure the similarity of the T. gibbosa extract to the fruiting body volatiles. T. gibbosa extract was diluted with GC-grade dichloromethane (Merck, Darmstadt, Germany) to obtain a concentration of 1-octen-3-ol, which showed to have a similar release rate of 1 -octen-3-ol as the fresh $T$. gibbosa fruiting body by performing headspace analysis of both samples. In one site of the Petri dish $50 \mu$ l of the diluted T. gibbosa extract was dropped on the filter paper and on the opposite side a cube $\left(1 \times 1 \times 0.5 \mathrm{~cm}^{3}\right)$ of fresh fruiting body was placed. Experiment 2: This experiment was done in order to measure the attraction of $C$. boleti to different doses of $(R)-(-)$ - and $(S)-(+)-1$-octen-3-ol. Dilution series of $10^{-5}-10^{-3}$ were prepared by mixing the pure enantiomers with paraffin oil. In one site of the Petri dish $20 \mu \mathrm{l}$ of paraffin oil solution was dropped on filter paper, whereas on the opposite side, only paraffin oil $(20 \mu \mathrm{l})$ was dropped on filter paper as a control. 


\subsection{Results}

\subsubsection{Volatile compounds of $T$. gibbosa extract}

A total of 23 volatile chemical compounds were characterised with GC-MS and GC-FID analyses of $T$. gibbosa extract. The identified compounds are listed in Table 6-1, where they are shown in an elution order according to the non-polar column and they are classified with regard to their chemical functions. The volatile compounds were categorised into six broad groups: alcohols, ketones, acids, aldehydes, terpenoids and aromatics. The most abundant compounds were five alcohols (49\%) comprising 1-octen-3-ol, 1-hexanol, 1 octanol, 3-octanol and (E)-2-octen-1-ol; eight aldehydes (45\%) comprising hexanal, heptanal, octanal, nonanal, (E)-2-heptenal, (E)-2-octenal, $(E, E)$-2,4-heptadienal and (E,E)2,4-decadienal; one ketone (5\%) 3-octanone; one terpene a-bisabolol. Two aromatics comprising of 2-pentyl furan and 2-methyl phenol and two acids comprising hexanoic and octanoic acids were present in trace quantities. The most dominant compound was 1 octen-3-ol (37\%), followed by hexanal (25\%), nonanal (6\%), (E)-2-octenal (5\%) and 3octanone (5\%). More detailed information is given in Table 6-1.

In the headspace analysis there were totally 15 volatiles identified. The volatile pattern was different from the extract, but both displayed similar volatile profile with 1-octen-3-ol being the dominant volatile and followed by hexanal. In addition to 1-octen-3-ol, and the other four alcohols previously identified, here we detected 1-pentanol. However, this compound was also present in the fruiting body extract but it was coeluted with the solvents. Among the other chemicals we detected four aldehydes comprising of heptanal, (E)-2-heptenal, octanal and nonanal; one ketone 3-octanone; two aromatic compounds 2pentyl furan and 2-methyl phenol and one terpene $\beta$-bisabolene.

The emission rate of 1-octen-3-ol in the headspace was calculated by comparing minimally and fully colonised fruiting bodies. 1-Octen-3-ol was found to be released at

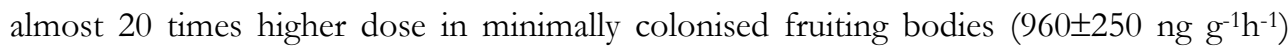
than in fully colonised fruiting bodies $\left(50 \pm 10 \mathrm{ng} \mathrm{g}^{-1} \mathrm{~h}^{-1}\right)$. This result was highly significant $[\mathrm{F}(1,7)=277.97, p<0.001]$. 
Table 6-1 Volatile compounds of Trametes gibbosa identified by GC-MS in fruiting body headspace and extract

\begin{tabular}{|c|c|c|c|c|c|c|c|}
\hline \multirow[t]{2}{*}{ No. } & \multirow[t]{2}{*}{ Compounds ${ }^{1}$} & \multicolumn{2}{|c|}{ Linear retention indices } & \multirow{2}{*}{$\begin{array}{c}\text { Quantity in } \\
\text { extract }^{2} \text { (ppm) }\end{array}$} & \multirow{2}{*}{$\begin{array}{l}\text { Proportion } \\
\text { in extract }{ }^{3}\end{array}$} & \multirow{2}{*}{$\begin{array}{l}\text { Proportion in } \\
\text { headspace }^{3}\end{array}$} & \multirow{2}{*}{$\begin{array}{c}\text { Chemical } \\
\text { classes }\end{array}$} \\
\hline & & HP-MS5 & INNOWAX & & & & \\
\hline 1 & acetic acid & n.d. & 1460 & tr. & tr. & - & acid \\
\hline 2 & propanoic acid & n.d. & 1540 & tr. & $\operatorname{tr}$. & - & acid \\
\hline 3 & butanoic acid & n.d. & 1629 & $\operatorname{tr}$. & $\operatorname{tr}$. & - & acid \\
\hline 4 & 1-pentanol & 779 & 1237 & tr. & tr. & 0.01 & alcohol \\
\hline 5 & hexanal & 803 & 1082 & 55 & 0.25 & 0.15 & aldehyde \\
\hline 6 & 1-hexanol & 879 & 1341 & 10 & 0.04 & 0.02 & alcohol \\
\hline 7 & heptanal & 907 & 1183 & 3 & 0.01 & tr. & aldehyde \\
\hline 8 & (E)-2-heptenal & 962 & 1324 & 7 & 0.03 & 0.01 & aldehyde \\
\hline 9 & 1-octen-3-ol & 980 & 1438 & 80 & 0.37 & 0.69 & alcohol \\
\hline 10 & 3-octanone & 990 & 1251 & 10 & 0.05 & 0.03 & ketone \\
\hline 11 & 2-pentyl furan & 993 & 1228 & tr. & tr. & tr. & aromatic \\
\hline 12 & 3-octanol & 995 & 1380 & 5 & 0.02 & 0.03 & alcohol \\
\hline 13 & hexanoic acid & 998 & 1843 & tr. & tr. & - & acid \\
\hline 14 & $\begin{array}{l}\text { octanal } \\
(E, E)-2,4-\end{array}$ & 1001 & 1287 & 1 & 0.01 & 0.01 & aldehyde \\
\hline 15 & heptadienal & 1020 & 1494 & tr. & tr. & - & aldehyde \\
\hline 16 & 2-methyl phenol & 1060 & 1993 & tr. & tr. & 0.01 & aromatic \\
\hline 17 & (E)-2-octenal & 1062 & 1428 & 11 & 0.05 & - & aldehyde \\
\hline 18 & (E)-2-octen-1-ol & 1067 & 1603 & 7 & 0.03 & 0.01 & alcohol \\
\hline 19 & 1-octanol & 1074 & 1542 & 5 & 0.02 & 0.03 & alcohol \\
\hline 20 & nonanal & 1106 & 1390 & 12 & 0.06 & 0.01 & aldehyde \\
\hline 21 & $\begin{array}{l}\text { octanoic acid } \\
(E, E)-2,4-\end{array}$ & 1182 & 2050 & tr. & tr. & - & acid \\
\hline 22 & decadienal & 1320 & 1806 & 8 & 0.04 & - & aldehyde \\
\hline 23 & $\beta$-bisabolene & 1516 & - & - & - & tr. & terpene \\
\hline 24 & $\alpha$-bisabolol & 1693 & 2228 & 4 & 0.02 & - & terpene \\
\hline
\end{tabular}

${ }^{1}$ The compounds were verified by comparing the mass spectra and retention indices of authentic standards, except $\beta$-bisabolene which was identified by matching the mass spectra with library and internal databases.

${ }^{2}$ tr.: trace, less than $1 \mathrm{ppm}$

${ }^{3}$ tr.: trace, less than 0.01

n.d.: non detected 
The enantioselective gas chromatography of 1-octen-3-ol showed an average $\alpha$-value of $1.04 \pm 0.02$ for the two enantiomers $(R)-(-)$ - and $(S)-(+)-1$-octen-3-ol. In the fruiting body extract the enantiomer ratio of $(R)-(-)$ - and $(S)-(+)-1$-octen-3-ol was $92.9 \%$ and $7.1 \%$, respectively.

\subsubsection{Electrophysiological response of $C$. boleti antennae to $T$. gibbosa volatiles}

Two types of experiments, GC-EAD and EAG were carried out to study the electrophysiological response of $C$. boleti to its host volatiles as shown in Table 6-2. The GC-EAD analysis of T. gibbosa extract yielded consistent responses to 1-octen-3-ol. The antennal activity of 10 males and 10 females of $C$. boleti adults was recorded and only 1 male and 2 female antennae did not show antennal response in correspondence with the elution of 1-octen-3-ol at the retention time of $12.93 \mathrm{~min}$ (Figure 6-1). We also recorded few responses to 3-octanone, in both male and female antennae ( 2 males and 1 female). Afterwards all the volatiles (23) present in the fruiting volatile body extract were tested in a $10 \mathrm{ng}$ quantity by performing GC-EAD to C. boleti antennae. It was found that 6 out of the 23 compounds were able to elicit antennal activity at different intensity. Those compounds were (E)-2-heptenal, 1-octen-3-ol, 3-octanone, octanal, (E,E)-heptadienal and nonanal. Among them, 1-octen-3-ol induced the strongest response $(0.46 \mathrm{mV})$, while the other compounds elicited weaker responses in a range of $0.1-0.2 \mathrm{mV}$.

The EAG experiments of the same 23 standard compounds $\left(10^{-3}\right.$ dilution in paraffin oil) showed that acetic acid elicited similar responses as the paraffin oil, therefore it was not considered as a stimulating compound. Propanoic and butanoic acids as well as $(E, E)$ 2,4-decadienal and $a$-bisabolol elicited very weak responses. 1-hexanol as well as the four C8 alcohols (1-octanol, 3-octanol, 1-octen-3-ol, (E)-2-octen-1-ol) elicited strong EAG responses.

A lower response was observed for 1-pentanol. In addition, there were four aldehydes (heptanal, (E)-2-heptenal, (E,E)-2,4-heptadienal and nonanal) which excited the antennae in the same range as the alcohol compounds. Dose-response curves of both enantiomers 
of the most sensitively detected compound, $(R)-(-)$ and $(S)-(+)-1$-octen-3-ol $\left(10^{-6}-10^{-3}\right.$ in paraffin oil) for C. boleti males and females were recorded (Figure 6-2). No significant differences were observed in the EAG response to either enantiomer between the $\operatorname{sexes}[(R)$-form, $\mathrm{F}(1,36)=3.72, \mathrm{p}=0.06$ and $(S)$-form, $\mathrm{F}(1,36)=2.55, \mathrm{p}=0.12]$. There were, however, differences with respect to the sexes and doses $[(R)$-form, $F(3,36)=10.41$, $\mathrm{p}<0.001$ and $(S)$-form, $\mathrm{F}(3,36)=8.32, \mathrm{p}<0.001]$. Among the ranges of the tested doses, the female beetles showed a small amount of scatter in their responses yielding three stages of dose discrimination, at $10^{-6}$, overlap of $10^{-5}-10^{-4}$, and $10^{-3}$. In comparison, the male beetles showed a higher degree of scatter in their responses yielding only two stages of discrimination at $10^{-6}-10^{-4}$ and $10^{-3}$.

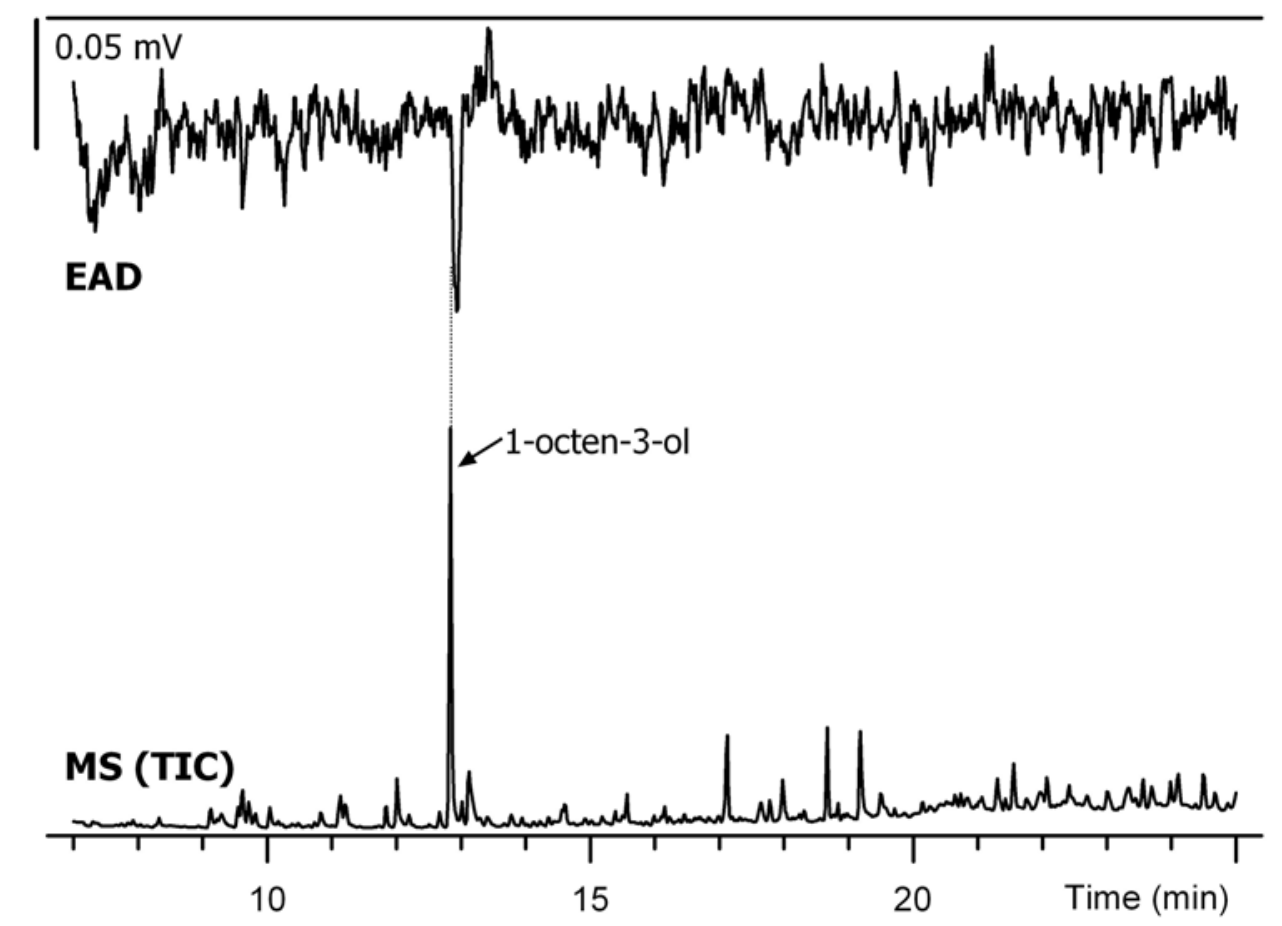

Figure 6-1 Gas chromatography (GC) - electroantennographic detection (EAD) and mass spectrometer (MS) chromatograms of C. boleti response to 1-octen-3-ol in $T$. gibbosa fruiting body extract. TIC: total ion current. 
Table 6-2 Electroantennographic responses of $C$. boleti antennae to $T$. gibbosa volatiles and standard compounds

\begin{tabular}{|c|c|c|c|c|c|}
\hline \multirow[b]{2}{*}{ No. } & \multirow[b]{2}{*}{ Compounds } & \multirow{2}{*}{$\begin{array}{l}\text { Quantity } \\
\text { in extract } \\
\text { (ppm) }\end{array}$} & \multirow{2}{*}{$\begin{array}{c}\text { EAG }^{\mathrm{a}} \\
10^{-3} \text { dilution in } \\
\text { paraffin oil }\end{array}$} & \multicolumn{2}{|c|}{ GC-EAD $^{b}$} \\
\hline & & & & $\begin{array}{c}10 \text { ng standard } \\
\text { compound }\end{array}$ & $\begin{array}{c}\text { T. gibbosa } \\
\text { extract }\end{array}$ \\
\hline 1 & acetic acid & tr. & & & \\
\hline 2 & propanoic acid & tr. & + & & \\
\hline 3 & butanoic acid & tr. & + & & \\
\hline 4 & 1-pentanol & tr. & ++ & & \\
\hline 5 & hexanal & 55 & ++ & & \\
\hline 6 & 1-hexanol & 10 & ++++ & & \\
\hline 7 & heptanal & 3 & ++++ & & \\
\hline 8 & (E)-2-heptenal & 7 & ++++ & $*$ & \\
\hline 9 & 1-octen-3-ol & 80 & +++++ & $* * * * *$ & $* *$ \\
\hline 10 & 3-octanone & 10 & +++ & $* *$ & $*$ \\
\hline 11 & 2-pentyl furan & tr. & ++ & & \\
\hline 12 & 3-octanol & 5 & ++++ & & \\
\hline 13 & hexanoic acid & tr. & + & & \\
\hline 14 & octanal & 1 & +++ & $* *$ & \\
\hline 15 & $(E, E)$-2,4-heptadienal & tr. & +++++ & $* *$ & \\
\hline 16 & 2-methyl phenol & tr. & +++ & & \\
\hline 17 & $(E)$-2-octenal & 11 & +++ & & \\
\hline 18 & (E)-2-octen-1-ol & 7 & +++ & & \\
\hline 19 & 1-octanol & 5 & ++++ & & \\
\hline 20 & nonanal & 12 & +++ & $* *$ & \\
\hline 21 & octanoic acid & tr. & ++ & & \\
\hline 22 & $(E, E)$-2,4-decadienal & 8 & + & & \\
\hline 23 & $\alpha$-bisabolol & 4 & + & & \\
\hline
\end{tabular}




\subsubsection{Behavioural test}

To ensure the similarity between the fruiting body and the extract, a behavioural test was carried out. The attraction index of the fruiting body against the extract was 0.53 . The activity index, which measures the induction of insect movement and searching behaviour, was equal to 0.65 . The attraction index revealed no statistical difference, showing that the extract has a similar attraction as the fruiting body.
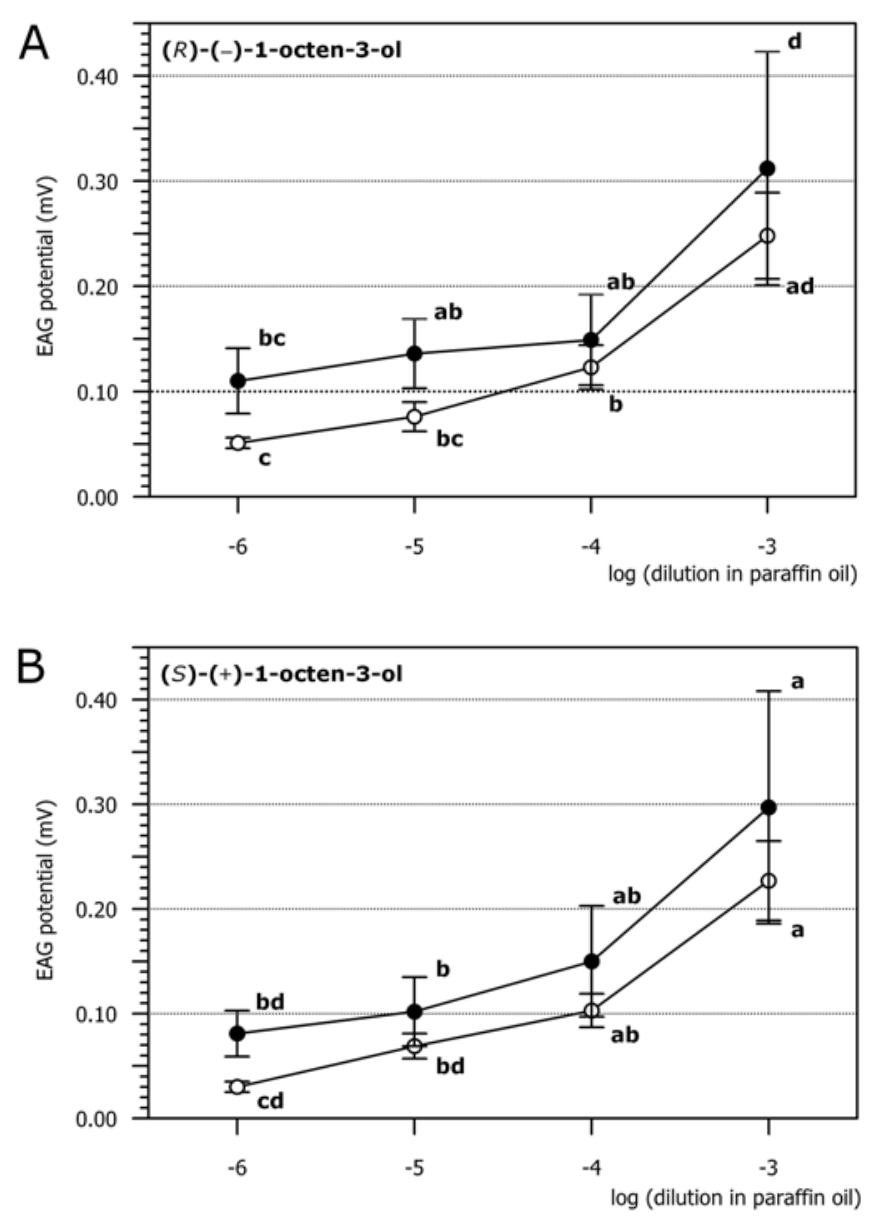

Figure 6-2 EAG responses (mean $\pm \mathrm{SE})$ of $C$. boleti males $(\bullet)$ and females $(\circ)$ to 1-octen-3ol. A: $(R)-(-)-1$-octen-3-ol, B: $(S)-(+)-1$-octen-3-ol. Different letters indicate significant differences between samples. 

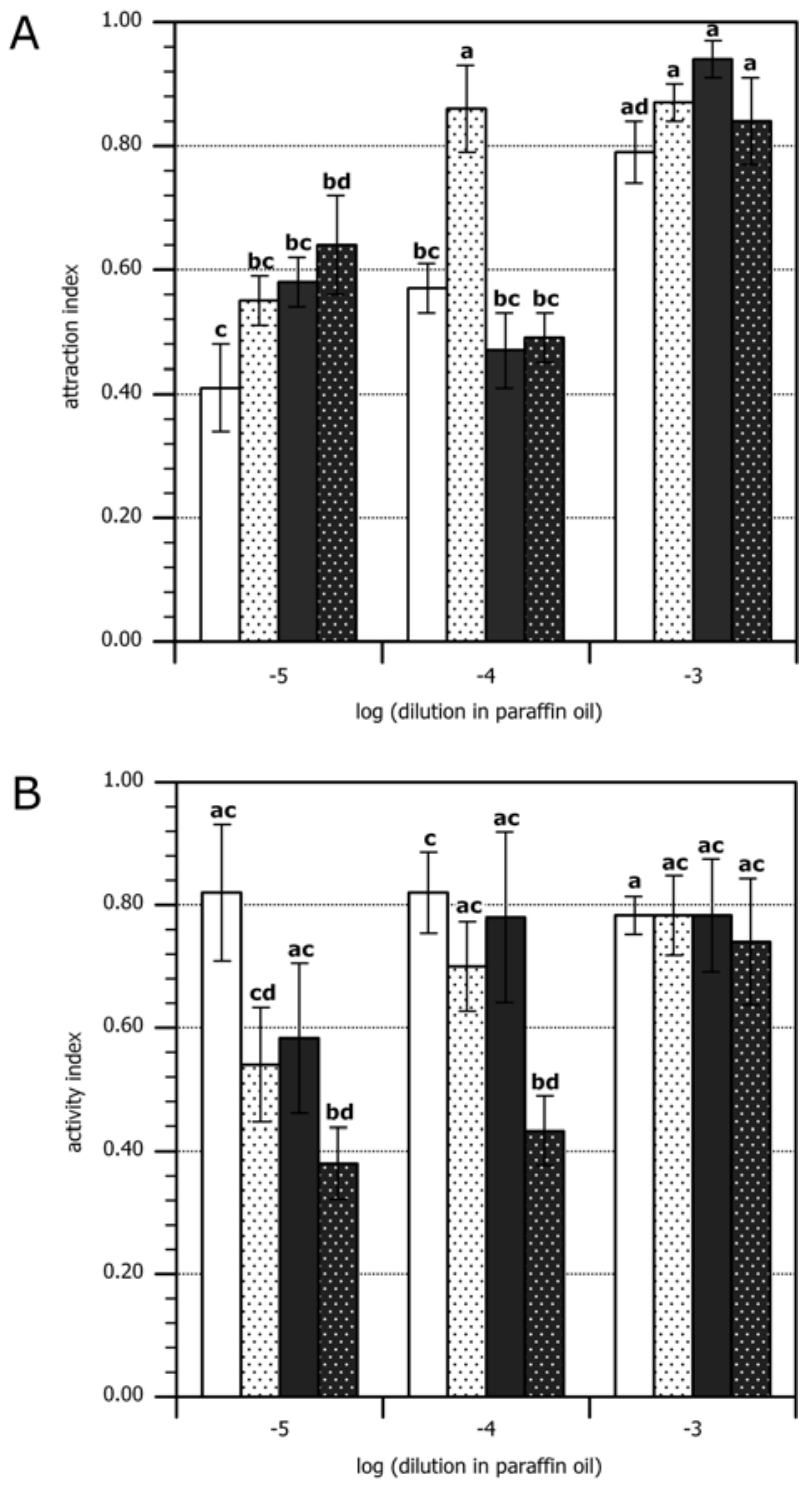

Figure 6-3 Behavioural responses to 1-octen-3-ol enantiomers. A: attraction index, B: activity index; white bar: female, dark bar: male, bar without dots: $(R)$-form and bar with dots: $(S)$ form. Values $=($ mean \pm SE $)$. Different letters indicate significant differences between samples. 
A second experiment was carried out to test the preference of $C$. boleti males and females to the two enantiomers of 1-octen-3-ol. The results are illustrated in Figures 6-3A and 6-3B, showing the attraction index and the activity index, respectively. No statistical difference was found between the sexes in the attraction to the two enantiomers $[F(1,52)$ $=0.49, \mathrm{p}=0.48]$. In each sex significant differences were observed in the attraction to each of the enantiomers $[\mathrm{F}(1,52)=6.50, \mathrm{p}<0.059]$ and among the different dilutions $[\mathrm{F}(2,52)=34.67, \mathrm{p}<0.001]$. The male beetles were significantly more attracted to both enantiomers at a dilution of $10^{-3}$ compared to a dilution of $10^{-4}$ and $10^{-5}$. The female beetles were significantly more attracted to $(R)-(-)-1$-octen-3-ol at a dilution of $10^{-3}$, but for the $(S)-(+)-1$-octen-3-ol they were already significantly more attracted to a dilution of $10^{-4}$. In Figures 6-3B, the activity index induced by $(R)-(-)-1$-octen-3-ol was high for both male and female beetles throughout the range of dilutions examined. The activity index of the male beetles induced by $(S)-(+)-1$-octen-3-ol was increased to the level of the $(R)-(-)$ enantiomer at a dilution of $10^{-3}$, whereas the female activity reached this level already at dilutions of $10^{-4}$.

\subsection{Discussion}

In Ciid beetles, fungal VOCs have been proposed as a mechanism in host finding (Jonsell and Nordlander 1995, 2004; Fäldt et al. 1999; Guevara et al. 2000). It has been hypothesised that two main VOCs fractions may play an important role in host finding by Ciid beetles: C8-compounds and terpenoids (Fäldt et al. 1999; Guevara et al. 2000). In T. gibbosa fruiting body we found a range of volatile compounds, including alcohols, terpenoids, aldehydes and aromatic compounds. Dichloromethane extract of T. gibbosa fruiting body showed a composition dominated by 1 -octen-3-ol (37\%), and other seven C8 compounds. The terpenoid fraction was characterised only by one sesquiterpenic alcohol, a-bisabolol. This compound was found in high proportion also in other woodrotting fungi as Schizophyllum commune (Ziegenbein et al. 2006) and Pblebia radiate (Gross et al. 1989). Interestingly in the headspace analysis we did not find this compound but $\beta$ bisabolene in trace quantity. Bisabolene and bisabolol share the same precursor, farnesyl 
diphosphate (Jones et al. 2006). Bisabolene is released by enzymatic reaction from fungal tissues and bisabolol is proposed to be a product of hydrolysis (Benedict et al. 2001; Köllner et al. 2004). Fruiting body extract and headspace share a similar volatile profile, although acidic compounds were not detected in the headspace, being possibly byprFoducts of acid hydrolysis of Soxhlet extraction. Extraction method allowed the identification of three aldehydes, which were not identified by headspace analysis, comprising (E,E)-2,4-heptadienal, (E)-2-octenal, (E,E)-2,4-decadienal.

We analysed the release rate of 1-octen-3-ol in two different colonisation stages and we found that T. gibbosa releases from 50 to $1000 \mathrm{ng} \mathrm{g}^{-1} \mathrm{~h}^{-1} \mathrm{of} 1$-octen-3-ol, with a higher release rate in case of minimally colonised fruiting body. The higher release rate of 1octen-3-ol in the minimally colonised fruiting body was most probably due to the fact that it was in a growing stage and had been additionally damaged by the insects. Whereas, the likely reason why there was a lower release rate in the fully colonised fruiting body was that tissues had been already consumed. Comparable release rates of 1-octen-3-ol have been found in other species of bracket fungi, also with a variation depending on the fungal age (factor of 100) and on the season (factor of 10) (Fäldt et al. 1999; Wu et al. 2005).

The enantiomeric composition of 1-octen-3-ol released by T. gibbosa displayed a ratio of 93:7 of the $(R)$ and $(S)$ enantiomers, respectively. The R:S of other bracket fungi species range in a species-specific manner, from a minimum of $89 \%$ to a maximum $98 \%$ of the (R)-enantiomer (Ziegenbein et al. 2006). For example, these authors found ratios of the (R)- and (S)-1-octen-3-ol of 90:10 in the wood-rotting fungi Schizophyllum commune and 98:2 in Datronia mollis hydrodistilates.

By coupling gas chromatography with mass-spectrometry and electroantennographic detection (GC-MS/EAD) of fruiting body extract, we proved for the first time that 1octen-3-ol elicits consistent responses to $C$. boleti antennae. Furthermore, 3-octanone was found to elicit occasionally antennal responses in this concentration range. To prove if other T. gibbosa volatiles are perceived by $C$. boleti beetles we performed GC-EAD analyses of all identified compounds in the extract, by running 10-ng of each authentic standard though the GC-EAD. In these experiments we found that the highest antennal response was elicited by 1-octen-3-ol, followed by 3-octanone, octanal, (E,E)-2,4-heptadienal, 
nonanal and (E)-2-heptenal (Table 6-2). A further investigation was done by performing EAG experiments with all volatiles identified in T. gibbosa at higher odour concentration $\left(10^{-3}\right.$ dilution in paraffin oil). Here we found that the acid compounds elicited very weak antennal responses, in agreement with the observation that they are not constituents of fruiting body volatiles but present in the extract as by-products. The alcohol fraction together with the aldehyde fraction elicited strong EAG responses. (E,E)-2,4-heptadienal showed similar response as 1-octen-3-ol, although in GC-EAD experiment we recorded a lower response than the one of 1-octen-3-ol. The only terpenoid with more than trace contribution to the fungal volatile pattern, $\alpha$-bisabolol, elicited very weak EAG response. Moreover, in behavioural experiments fresh fruiting body compared with fruiting body extract showed similar attraction to the beetles. We may therefore suppose that terpenoids do not play a major role in host finding. Therefore, we focus our attention on 1-octen-3ol, which is the major component of the fungal volatile bouquet and elicits the strongest antennal response. In behavioural test, the female beetles showed a statistically higher attraction to a dose of the $(S)$-enantiomer equal to $10^{-4}$, while a dose equal to $10^{-3}$ was necessary to show a statistically higher attraction for the $(\mathrm{R})$-enantiomer. The males were strongly attracted only to the high dose $\left(10^{-3}\right)$ and did not show a discriminated behaviour between the two enantiomers. Moreover, the searching activity of female beetles was increased selectively by even the lower release rates of $(S)-(+)-1$-octen-3-ol. Such an enantiomeric discrimination has been observed in several other insect species, both at the electrophysiological and at the behavioural level (Ulland et al. 2006), and convincing examples have been found in pheromone perception (Kozlov et al. 1996). For instance, the cabbage moth, Mamestra brassicae, detected enantiomers of linalool with different intensity, showing ten times higher sensitivity to $(R)-(-)$-linalool than to $(S)-(+)$-linalool (Ulland et al. 2006). However, in this study, it is the first time that an enantiomeric discrimination for Ciid beetles has been demonstrated. The results of the behavioural assays suggested that female beetles play a major role in the fruiting body colonisation of bracket fungi. This assumption is in agreement with the results reported by Fäldt et al. (1999), where a higher number of wood-decomposing female beetles were found in 1octen-3-ol baited traps. Moreover, also in the deathwatch beetle, Xestobium rufovillosum 
(Coleoptera, Anobiidae) females perform the first colonisation of fungal decayed wood (Fisher 1940; Belmain et al. 1998). The task of colonising pioneers is not only to locate and to identify a suitable fungus species but also to assess the developmental stage and age of the fruiting body. C. boleti is reported to be frequently a second coloniser following a first colonisation made by the Ciid beetle Octotemnus glabriculus (Guevara et al. 2000). The activity of the first insects colonising a fungal host causes damage to the fruiting body and consequently alters the pattern of VOCs. This variation in the volatile profile may be an important hint for host suitability to second-coloniser Ciid beetles and allows a successive colonisation of the fungal fruiting bodies.

In this study, it was shown that minimally colonised fruiting bodies release 1-octen-3-ol at high emission rates. Moreover, it was demonstrated in the electrophysiological and behavioural tests that $C$. boleti beetles are able to perceive and to behaviourally respond to 1-octen-3-ol. The two enantiomers of 1-octen-3-ol affect the behaviour of female and male beetles in a different manner. Thus, 1 -octen-3-ol emission rate and enantiomeric ratio are important information for host fungus suitability. These results do not exclude that other volatiles detected at higher concentrations may contribute to host discrimination, while 1-octen-3-ol is important in host finding. Whether the differences in the enantiomeric ratios of 1-octen-3-ol in various fungal species are sufficient to allow Ciid beetles to differentiate between fungal species needs further confirmation. In order to understand better the mechanisms of host selection in Ciid beetles more investigations of the volatile composition during fungal development are needed. Moreover, the distribution of the antennal sensilla as well as analysis with single sensillum recording could allow characterising the olfactory structures responsible for enantiomeric discrimination and fungal volatile perception in these insects.

\section{Acknowledgements}

Prodpran Thakeow is grateful to the Royal Thai Government and Chiang Mai University for their financial support. The authors would like to thank Dr. Norbert Menke, Forestry Experimental Station, Lower Saxony, Germany, for insect classification and Dr. Holm 
Frauendorf, Institute of Organic and Molecular Chemistry, Faculty of Chemistry,

Göttingen University, for 1-octen-3-ol enantiomer identification.

\subsection{References}

Belmain SR, Blaney WM, Simmonds MSJ. 1998. Host selection behaviour of deathwatch beetle, Xestobium rufovillosum: Oviposition preference choice assays testing old $v s$ new oak timber, Quercus sp. Entomologia Experimentalis et Applicata 89: 193-199.

Benedict CR, Lu JL, Pettigrew DW, Liu J, Stipanovic RD, Williams HJ. 2001. The cyclization of farnesyl diphosphate and nerolidyl diphosphate by a purified recombinant $\delta$-cadinene synthase. Plant Physiology 125: 1754-1765.

Boddy L. 1991. Importance of wood decay fungi in forest ecosystems. In: Arora DK, Rai B, Mujerji KG, Knudsen GR (Eds). Handbook of applied mycology. Soils and plants. Vol. 1. Marcel Dekker, Inc., New York. pp. 507-540.

Boddy L, Watkinson SC. 1995. Wood decomposition, higher fungi, and their role in nutrient redistribution. Canadian Journal of Botany 73 (Suppl.): S1377-S1383.

Ewen RJ, Jones PRH, Ratcliffe NM, Spencer-Phillips PTN. 2004. Identification by gas chromatography-mass spectrometry of the volatile organic compounds emitted from the wood-rotting fungi Serpula lacrymans and Coniophora puteana, and from Pinus sylvestris timber. Mycological Research 108: 806-814.

Fäldt J, Jonsell M, Nordlander G, Borg-Karlson AK. 1999. Volatiles of bracket fungi Fomitopsis pinicola and Fomes fomentarius and their functions as insect attractants. Journal of Chemical Ecology 25: 567-590.

Färbert P, Koch UT, Färbert A, Staten RS, Cardé RT. 1997. Pheromone concentration measured with electroantennogram in cotton fields treated for mating disruption of Pectinophora gossypiella (Lepidoptera: Gelechiidae). Environmental Entomology 26: 11051116.

Fisher RC. 1940. Studies of the biology of the deathwatch beetle, Xestobium rufovillosum de Geer: Part III, fungal decay in timber in relation to the occurrence and rate of development of the insect. Annals of Applied Biology 27: 545-557.

Fossli TE, Andersen J. 1998. Host preference of Cisidae (Coleoptera) on tree-inhabiting fungi in northern Norway. Entomologia Fennica. 9: 65-78.

Gross B, Gallois A, Spinnler HE, Langlois D. 1989. Volatile compounds produced by the ligninolytic fungus Pblebia radiata Fr. (Basidiomycetes) and influence of the strain specificity on the odorous profile. Journal of Biotechnology 10: 303-308.

Guevara R, Rayner ADM, Reynolds S. 2000. Effects of fungivory by two specialist Ciid beetles (Octotemnus glabriculus and Cis boleti) on the reproductive fitness of their host fungus, Coriolus versicolor. New Phytology 145: 137-144.

Guevara R, Rayner ADM, Reynolds S. 2000a. Orientation of specialist and generalist fungivorous ciid beetles to host and non-host odours. Physiological Entomology 25: 288295.

Guevara R, Hutcheson KA, Mee AC, Rayner ADM, Reynolds SE. 2000b. Resource partitioning of the host fungus Coriolus versicolor by two ciid beetles: the role of odour compounds and host ageing. Oikos 91: 184-194. 
Guevara R, Rayner ADM, Reynolds SE. 2000c. Orientation of specialist and generalist fungivorous ciid beetles to host and non-host odours. Physiol Entomol. 25: 288-295.

Hadar Y, Dosoretz CG. 1991. Mushroom mycelium as a potential source of food flavour. Trends in Food Science and Technology 2: 214-218.

Hanski I. 1989. Fungivory: fungi, insects and ecology. In: Wilding N, Collins NM, Hammond PM, Webber JF (Eds). Insect-Fungus Interactions. Academic Press, London. pp. 25-68.

Jones CG, Ghisalberti EL, Plummer JA, Barbour EL. 2006. Quantitative co-occurrence of sesquiterpenes; a tool for elucidating their biosynthesis in Indian sandalwood, Santalum album. Phytochemistry 67: 2463-2468.

Jonsell M, Nordlander G. 1995. Field attraction of Coleoptera to odours of the wood-decaying polypores Fomitopsis pinicola and Fomes fomentarius. Annales Zoologici Fennici 32: 391-402.

Jonsell M, Nordlander G. 2004. Host selection patterns in insects breeding in bracket fungi. Ecological Entomology 29: 697-705.

Kaissling KE, Thorson J. 1980. Insect Olfactory Sensilla: Structural, Chemical and Electrical Aspects of the Functional Organisation. In: Satelle DB, Hall LM, Hildebrand JG (Eds). Receptors for Neurotransmitters, Hormones and Pheromone in Insects. Elsevier/NorthHolland Biomedical Press, Amsterdam. pp. 261-282.

Köllner TG, Schnee C, Gershenzon J, Degenhardt J. 2004. The variability of sesquiterpenes emitted from two Zea mays cultivars is controlled by allelic variation of two terpene synthase genes encoding stereoselective multiple product enzymes. Plant cell 16: 11151131.

Komonen A, Kouki J. 2005. Occurrence and abundance of fungus-dwelling beetles (Ciidae) in boreal forests and clearcuts: habitat associations at two spatial scales. Animal Biodiversity and Conservation 28.2: 137-147.

Kozlov MV, Zhu J, Philipp P, Francke W, Zvereva EL, Hansson BS, Löfstedt C. 1996. Pheromone specificity in Eriocrania semipurpurella (Stephens) and E. sangii (Wood) (Lepidoptera: Eriocraniidae) based on chirality of semiochemicals. Journal of Chemical Ecology 22: 431-454.

Lawrence JF. 1973. Host preference in ciid beetles (Coleoptera: Ciidae) inhabiting the fruiting body of Basidiomycetes in North America. Bulletin of the Museum of Comparative Zoology at Harvard University 145: 163-212.

Rösecke J, König WA. 2000. Constituents of various wood-rotting basidiomycetes. Phytochemistry 54: 603-610.

Rösecke J, Pietsch M, König WA. 2000. Volatile constituents of wood-rotting basidiomycetes. Phytochemistry 54: 747-750.

Schütz S, Weißbecker B, Koch UT, Hummel HE, 1999. Detection of volatiles released by diseased potato tubers using a biosensor on the basis of intact insect antennae. Biosensors and Bioelectronics 14: 221-228.

Thakeow P, Weißbecker B, Schütz S. 2006. Volatile organic compounds emitted from fungalrotting beech (Fagus sylvatica). Mitteilungen der Deutschen Gesellschaft für allgemeine und angewandte Entomologie 15: 157-160.

Thakeow P, Holighaus G, Schütz S. 2007. Volatile compounds for wood assessment. In: Kües U. (Ed). Wood production, wood technology and biotechnological impacts. Universitätsverlag Göttingen, Göttingen. pp. 197-228.

Tressl R, Bahri D, Engel KH. 1982. Formation of eight-carbon and ten-carbon components in mushrooms (Agaricus campestris). Journal of agricultural and food chemistry 30: 89-83. 
Ulland S, Ian E, Borg-Karlson A-K, Mustaparta H. 2006. Discrimination between enantiomers of linalool by olfactory receptor neurons in the cabbage moth Mamestra brassicae (L.). Chemical Senses 31: 325-334.

Van den Dool H, Kratz PD. 1963. A generalization of the retention index system including linear temperature programmed gas-liquid partition chromatography. Journal of Chromatography 11: 463-471.

Weissbecker B, Holighaus G, Schütz S. 2004. Gas chromatography with mass spectrometric and elecroantennographic detection: analysis of wood odorants by direct coupling of insect olfaction and mass spectrometry. Journal of Chromatography A 1056: 209-216.

Wheatley RE, Hackett C, Bruce A, Kundzewicz A. 1997. Effect of substrate composition on production and inhibitory activity against wood decay fungi of volatile organic compounds from Trichoderma spp. International Biodeterioration and Biodegradation. 39: 199-205.

Wheatley RE. 2002. The consequences of volatile organic compound mediated bacterial and fungal interactions. Antonie van Leeuwenhoek. 81: 257-264.

Wu S, Zorn H, Krings U, Berger RG. 2005. Characteristic volatiles from young and aged fruiting bodies of wild Polyporus sulfureus (Bull.:Fr.) Fr. Journal of agricultural and food chemistry 53: 4525-4528.

Wurzenberger M, Grosch W. 1982. The enzymic oxidative breakdown of linoleic acid in mushrooms (Psalliota bispora). Zeitschrift für Lebensmittel-Untersuchung und-Forschung 175: 186-190.

Zabel RA, Morrell JJ. 1992. Wood Microbiology: decay and its prevention. Academic Press, Inc., New York.

Zeppa S, Gioacchini AM, Guidi C, Guescini M, Pierleoni R, Zambonelli A, Stocchi V. 2004. Determination of specific volatile organic compounds synthesised during Tuber borchii fruit body development by solid-phase microextraction and gas chromatography/mass spectrometry. Rapid Communications in Mass Spectrometry 18: 199-205.

Ziegenbein RC, Hanssen HP, König WA. 2006. Chemical constituents of the essential oils of three wood-rotting fungi. Flavour and Fragrance Journal 21: 813-816. 


\section{CHAPTER 7}

Electroantennographic response of Suillia mikii to volatiles released by autolytic Coprinus comatus,

Coprinopsis cinerea, and Coprinopsis atramentaria

fruiting bodies 



\subsection{Abstract}

The headspace-volatile organic compounds (HS-VOCs) of Coprinus comatus, Coprinopsis cinerea, and Coprinopsis atramentaria, were examined by using two sampling techniques, close loop stripping analysis and solid phase microextraction. The VOCs were analysed using gas chromatography-mass spectrometry (GC-MS). Twenty seven volatile compounds were identified in the headspace of fruiting bodies in their autolytic stages, covering seven chemical classes, alcohols, ketones, aldehydes, esters, hydrocarbons, N-containing and Scontaining compounds. Among the detected VOCs, 11 were alcoholic compounds, including 3-methyl-1-butanol as a frequent main constituent. Besides alcohols, there were $\mathrm{N}, \mathrm{N}$-dimethyl formamide, benzoxazol, indole as N-containing compounds and dimethyl trisulphide as S-containing compound. These compounds might contribute to the pungent odour of these fungi in their autolytic stage. The HS volatile extracts were used for an electrophysiological examination of the olfactory perception by the associated fly Suillia mikii (Diptera; Heleomyzidae). Electroantennographic detection coupled with GC-MS showed that the adults of $S$. mikii reproducibly responded to five volatiles released by the autolytic fruiting bodies. Those were ethyl acetate, 1-undecene, 2-nonanone, dimethyl trisulphide and one unidentified compound. These compounds are specifically formed during the autolytic stage of fruiting body development when the fungal sporulation takes place. Therefore, the examined Coprinus and Coprinopsis species might benefit from the attraction of the flies by providing additional dispersal of their spores.

Keywords: fungal feeding insect, VOCs, host selection, GC-MS/EAD 


\subsection{Introduction}

Fruiting body development of fungi is a complex process as exemplified in the Basidiomycete Coprinus cinereus (Kües 2000). During the development, many biochemical processes take place, necessarily resulting in a release of volatile organic compounds (VOCs). Basidiomycetes in different developmental stages, as mycelium, immature and mature fruiting bodies, release different VOC patterns as shown for several Agaricus species (Keshri et al. 2003) and for Coprinopsis cinerea (Thakeow et al. manuscript in preparation). In a similar way, fruiting bodies of the Ascomycete Tuber borchii with different mature spore contents release specific patterns of VOC (Zeppa et al. 2004). Similar to plant volatiles, these fungal VOCs might be unavoidable by-products of developmental processes or compounds released for communication purposes. Interspecific communication might have developed by co-evolution, as some indication was found in fungus-plant interaction (Akiyama et al. 2005) and fungus-insect interaction (Thakeow et al. 2007). Many fungivorous insects feeding on different fungal parts like mycelium, fruiting bodies or spores (Lawrence 1989) rely on chemical cues for host fungal finding and identification (Fäldt et al. 1999; Thakeow et al. 2008).

The aim of this study is to chemically characterise the volatiles specific to the autolytic stage of three Coprinopsis species and to electrophysiologically identify the volatiles perceived by the associated fly Suillia mikii.

\subsection{Materials and methods}

\subsubsection{Fungi and insects}

The fruiting bodies of $C$. comatus and $C$. atramentaria were collected from the surroundings of Göttingen, Germany. The fruiting bodies of $C$. cinerea were kindly provided by Prof. Ursula Kües and Wassana Chaisaena, Section of Molecular Wood Biotechnology, GeorgeAugust-University Göttingen. The Suillia mikii (Diptera; Helomyzidae) flies were caught after their targeted flight and landing on the autolytic fruiting bodies of the Coprinopsis 
species. Fungal samples and insects were stored at $8^{\circ} \mathrm{C}$ in the dark prior to the experiments.

\subsubsection{Analysis of $C$. comatus, $C$. atramentaria, and $C$. cinerea volatile organic compounds}

Sampling of volatiles from five grams samples of autolytic fruiting bodies in 60-ml septum cap vials was carried out by using two sampling techniques, close loop stripping analysis (CLSA) and solid phase microextraction (SPME). CLSA-tubes (CLSA-Filter, Gränicher + Quartero, Daumazan, France) containing activated charcoal were used for active sampling the volatiles released into the septum cap vials for $30 \mathrm{~min}$ at a sampling rate of $160 \mathrm{ml}$ $\min ^{-1}$. After that, the trapped volatiles were eluted by a solvent mixture of methanol (GCgrade, Merck, Germany) and methylene chloride (Suprasolv-grade, Merck, Germany) (ratio 2:1). The obtained solution was kept at $-80^{\circ} \mathrm{C}$ for further analysis. A SPME fibre, Carboxen $^{\mathrm{TM}} /$ Polydimethylsiloxane (PDMS) StableFlex ${ }^{\mathrm{TM}}$ (polymer thickness $85 \mu \mathrm{m}$ ) (Supelco, USA) was used for passive sampling. Prior to sampling, the fibre was cleaned by exposing it in the GC injection port for $5 \mathrm{~min}$ at $250^{\circ} \mathrm{C}$ and helium flow of $1.0 \mathrm{ml} \mathrm{min}{ }^{-1}$. After that, the sampling was carried out by exposing the fibre in the headspace of the septum cap vial for $30 \mathrm{~min}$. Later the fibre was retracted to its housing, and for analysis, it was directly injected to GC injection port.

The gas chromatograph (GC, HP-6890N, Agilent Technologies, Paolo Alto, USA) was equipped with a polar column of INNOWAX (30 m x $0.25 \mathrm{~mm}$ i.d., $0.25 \mu \mathrm{m}$ film thickness). Helium was used as a carrier gas with flow rate $1.0 \mathrm{ml} \mathrm{min}^{-1}$. The GC operating programs for those two sampling methods are shown in Table 7-1. 
Table 7-1 GC operating programs for volatiles sampled with CLSA and SPME methods

\begin{tabular}{cccccc}
\hline Method & $\begin{array}{c}\text { Initial } \\
\text { temperature } \\
\left({ }^{\circ} \mathrm{C}\right)\end{array}$ & $\begin{array}{c}\text { Time at initial } \\
\text { temperature } \\
(\mathrm{min})\end{array}$ & $\begin{array}{c}\text { Heating } \\
\text { rate } \\
\left({ }^{\circ} \mathrm{C} \mathrm{min}^{-1}\right)\end{array}$ & $\begin{array}{c}\text { Final } \\
\text { temperature } \\
\left({ }^{\circ} \mathrm{C}\right)\end{array}$ & $\begin{array}{c}\text { Hold time at final } \\
\text { temperature } \\
(\mathrm{min})\end{array}$ \\
\hline CLSA & 50 & 1.5 & 6.5 & 250 & 10 \\
SPME & 40 & 1.5 & 7.0 & 200 & 10 \\
\hline
\end{tabular}

The mass spectrometric analysis was performed by an MS-5973N (Agilent Technologies, Paolo Alto, USA) with the mass scan range of 20-400 amu, source temperature of $230^{\circ} \mathrm{C}$ and $\mathrm{EI}$ mode at $70 \mathrm{eV}$. The chromatograms were analysed with the database of Massfinder version 3.0 software together with the library "Terpenoids and Related Constituents of Essential Oils” (Hochmuth, König, Joulain, Hamburg, Germany), Enhance chemstation version D00.00.38 (Agilent Technologies, Paolo Alto, USA) and National Institute of Standards and Technology (NIST, Gaithersburg, USA) Mass Spectral Search program. The identification of compounds was confirmed by matching of mass spectra and retention times of authentic standards with the original samples.

\subsubsection{Electrophysiological response of $S$. mikii to $C$. comatus, $C$. atramentaria, and $C$. cinerea volatiles}

The electrophysiological response of $S$. mikii to $C$. comatus, $C$. cinerea, and $C$. atramentaria volatiles was accomplished on HP 6890N GC equipped with INNOWAX column (Agilent Technologies, Paolo Alto, USA) with a dimension of $30 \mathrm{~m}$ x $0.25 \mathrm{~mm}$ i.d., 0.25 $\mu \mathrm{m}$ film thickness. The end of the column was separated into two paths, (i) mass spectrometer (MS) and (ii) electroantennographic detection (EAD). Two pieces of deactivated capillary were connected to a Graphpack 3D/2 flow splitter (Gerstel, Mülheim, Germany), in which one capillary $(1 \mathrm{~m}$ x $0.1 \mathrm{~mm}$, i.d.) led to the MS and the other (1 $\mathrm{m}$ x $0.15 \mathrm{~mm}$, i.d.) joined to an olfactory detector port (ODP-2, Gerstel, Mülheim an der Ruhr, Germany). The detailed description of the setup is given in Weissbecker et al. (2004). 
In order to adapt the GC effluent to optimum conditions to the insect antenna humidified air at room temperature with a flow rate of $20 \mathrm{l} \mathrm{h}^{-1}$ was added as a make-up gas. The insect antenna was cut and placed in an antenna holder (Prof. Dr. Uwe Koch, Kaiserslautern, Germany) (Färbert et al. 1997). Both ends of the antennae were immersed in an adapted-insect-hemolymph electrolyte solution (Kaissling and Thorson 1980). This solution brought contact to a pair of $\mathrm{Ag} / \mathrm{AgCl}$ electrodes. The signal was later amplified and conversed by an A/D converter type 35900E (Agilent Technologies, Paolo Alto, USA), the signal was recorded by the Agilent GC Chem-Station software (Agilent Technologies, Paolo Alto, USA).

\subsection{Results}

\subsubsection{Volatiles of $C$. comatus, $C$. atramentaria, and $C$. cinerea}

The volatiles of autolysis C. comatus, C. atramentaria, and C. cinerea fruiting body were collected by two sampling methods, CLSA (active sampling) and SPME (passive sampling). These two methods complement each other since not all compounds can be sampled by one of these two methods. There were totally 27 compounds identified and categorised in seven groups, alcohols, ketones, aldehydes, esters, hydrocarbons, Ncontaining and S-containing compounds (Table 7-1). Alcohols contributed the major fraction (11 alcoholic compounds). The samples had a pungent odour, likely resulting from the N-containing compounds of N,N-dimethyl formamide, benzoxazol and indole, and from the S-containing compounds of dimethyl disulphide and dimethyl trisulphide. 
7.4.2. Electrophysiological response of $S$. mikii fly to $C$. comatus, $C$. atramentaria, and $C$. cinerea volatiles

The results of GC-MS/EAD are illustrated in Figure 7-1. It was clearly revealed that the fly reproducibly responded to five compounds of the autolytic C. comatus and $C$. atramentaria fruiting bodies with different intensities. Those compounds were ethyl acetate, 1-undecene, 2-nonanone, dimethyl trisulphide, and an unidentified compound.
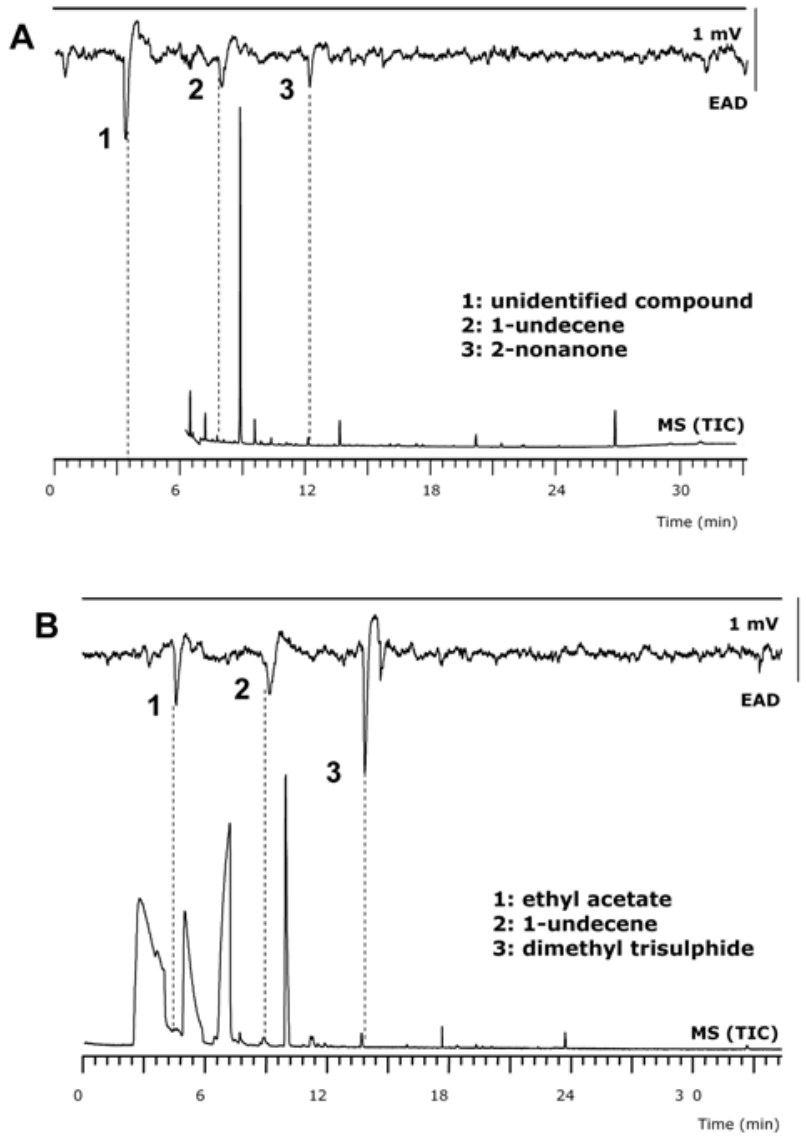

Figure 7-1 Gas chromatogram (GC) - electroantennographic detection (EAD) and mass spectrogram (MS) of Suillia mikii fly to the volatiles of autolytic fruiting bodies. (A) VOCs of Coprinus comatus sampled by close loop stripping analysis and (B) VOCs of Coprinopsis atramentaria by solid phase microextraction. 
Table 7-2 Volatiles of autolysis Coprinus comatus, Coprinopsis atrametaria and Coprinopsis cinerea

\begin{tabular}{|c|c|c|c|c|c|c|}
\hline \multirow[t]{2}{*}{ Compound } & \multirow{2}{*}{$\begin{array}{l}\text { Chemical } \\
\text { structure }\end{array}$} & \multirow{2}{*}{$\begin{array}{l}\text { Retention } \\
\text { index }\end{array}$} & \multirow{2}{*}{$\begin{array}{l}\text { CLSA } \\
\text { FG1* }\end{array}$} & \multicolumn{3}{|c|}{ SPME } \\
\hline & & & & FG1* & FG2* & FG3* \\
\hline \multicolumn{7}{|l|}{ Alcohols } \\
\hline ethanol $^{\mathrm{b}}$ & & $<1100$ & & + & & \\
\hline 1-propanol ${ }^{\mathrm{e}}$ & & $<1100$ & + & & & \\
\hline 2-methyl-1- & & $<1100$ & + & + & & \\
\hline propanol $^{\mathrm{g}}$ & & & & & & \\
\hline 3-methyl-1-butanol ${ }^{\mathrm{a}}$ & & 1206 & + & + & & + \\
\hline 1-hexanol ${ }^{c}$ & & 1350 & & & + & \\
\hline 2-ethyl-1-hexanol ${ }^{\text {b }}$ & & 1475 & + & & & + \\
\hline & & & & & & \\
\hline 1-octen-3-ol ${ }^{\mathrm{b}}$ & & 1438 & & + & & + \\
\hline phenyl ethyl alcohol $^{c}$ & & 1899 & + & + & + & \\
\hline phenol $^{\mathrm{a}}$ & & 1989 & + & & + & \\
\hline 4-methyl phenol ${ }^{\mathrm{f}}$ & & 2059 & + & & & \\
\hline 3-methyl phenol ${ }^{\mathrm{a}}$ & & 2067 & + & & + & \\
\hline
\end{tabular}


Table 7-2 continued

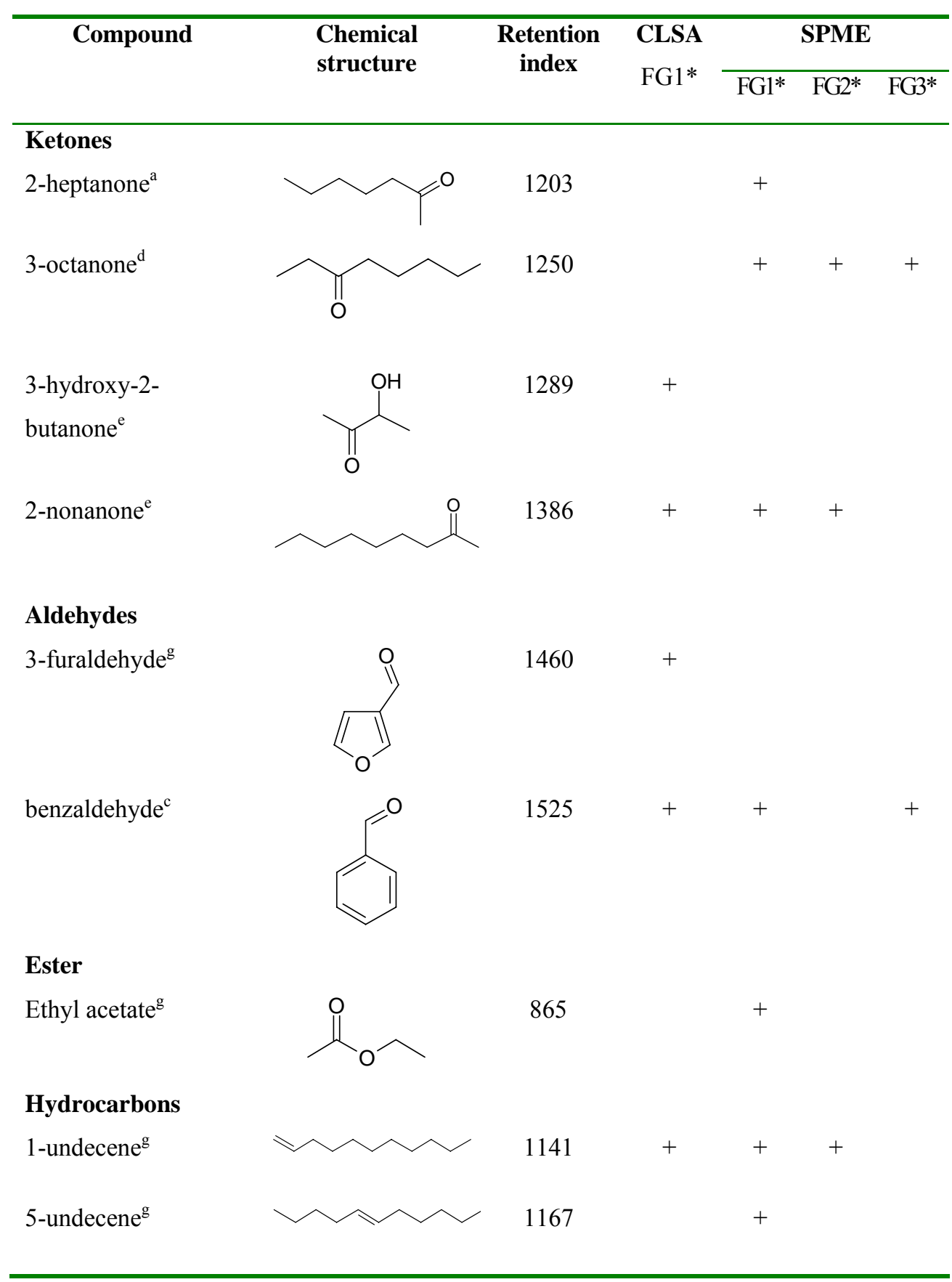


Table 7-2 continued

\begin{tabular}{|c|c|c|c|c|c|c|}
\hline \multirow[t]{2}{*}{ Compound } & \multirow{2}{*}{$\begin{array}{l}\text { Chemical } \\
\text { structure }\end{array}$} & \multirow{2}{*}{$\begin{array}{l}\text { Retention } \\
\text { index }\end{array}$} & \multirow{2}{*}{$\begin{array}{l}\text { CLSA } \\
\text { FG1* }\end{array}$} & \multicolumn{3}{|c|}{ SPME } \\
\hline & & & & FG1* & FG2* & FG3* \\
\hline \multicolumn{7}{|l|}{ Sesquiterpenes } \\
\hline$\beta$-himachalene & & & & & & + \\
\hline cuparene & & 1505 & & & & + \\
\hline \multirow{2}{*}{\multicolumn{7}{|c|}{$\begin{array}{l}\text { N-containing } \\
\text { compounds }\end{array}$}} \\
\hline & & & & & & \\
\hline $\mathrm{N}, \mathrm{N}$-dimethyl & & 1329 & + & & & \\
\hline \multicolumn{7}{|l|}{ formamide $^{\mathrm{g}}$} \\
\hline benzoxazol $^{\mathrm{g}}$ & & 1652 & & + & + & \\
\hline indole $^{\mathrm{e}}$ & & $>2200$ & + & + & + & + \\
\hline \multicolumn{7}{|l|}{ S-containing } \\
\hline \multicolumn{7}{|l|}{ compound } \\
\hline dimethyl disulphide ${ }^{\mathrm{g}}$ & & 1103 & & & & + \\
\hline dimethyl trisulphide ${ }^{\mathrm{g}}$ & & 1387 & + & + & + & \\
\hline
\end{tabular}

*FG1: Coprinus comatus, FG2: Coprinopsis atramentaria, and FG3: Coprinopsis cinerea The compounds were verified by comparing them with mass spectra and RIs from the institute's internal database and co-elution with authentic standards:

${ }^{a}$ Aldrich, Steinheim, Germany

${ }^{\mathrm{b}}$ Merck, Darmstadt, Germany

${ }^{c}$ Acros, Geel, Belgium

${ }^{\mathrm{d}}$ VWR, Darmstadt, Germany

${ }^{\mathrm{e}}$ Fluka, Buchs, Switzerland

${ }^{f}$ ABCR, Karlsruhe, Germany

${ }^{g}$ by matching the mass spectra with library databases 


\subsection{Discussion}

To effectively identify volatile organic compounds (VOCs), it is worth to perform experiments by using two sampling techniques. In this manner, more complete volatile profile can be accomplished, since each sampling method, i.e., SPME and CLSA, possesses its own advantage and disadvantage. SPME is a powerful sampling technique, which has been developed since the 1990s, and is widely used in many research areas (Pawliszyn 1997). There are advantages to do experiments using SPME that are solventfree, straightforward, inexpensive, and covering wide ranges of chemicals (Zhang et al. 1994). However, a disadvantage by using SPME as a sampling method is that it is a oneshot experiment. This means when the SPME fibre is injected to the GC injection, all the volatiles are released and there is no more volatile left for further experiments. This drawback can be overcome by using CLSA sampling method since the collected volatiles on the activated charcoal are eluted with solvent, which could be kept for several experiments. Nevertheless, using solvents hinders the identification of small compounds, like ethanol with retention times in the range of the solvent retention time. As shown in Figure 7-1 and Table 7-2 there were compounds which were sampled by SPME but not by CLSA. Those were ethanol, 1-hexanol, 1-octen-3-ol, 2-heptanone, 3-octanone and benzoxazol. At the same time, there were compounds which were collected by CLSA but not by SPME. Those were 1-propanol, 3-methyl phenol, 4-methyl phenol, 3-furaldehyde and $\mathrm{N}, \mathrm{N}$-dimethyl formamide. This difference might rise from volatility of the compounds and the different selectivity of the adsorbents.

3-Methyl-1-butanol was a dominant compound and is found to be released also from many other types of fungi such as Trametes versicolor (Thakeow and Schütz manuscript in preparation). This 3-methyl-1-butanal (dehydrogenated form of 3-methyl-1-butanol) was marked to be released from the dead mycelium of Serpula lacrymans (Ewen et al. 2004). The typical fungal odour of 1-octen-3-ol and 3-octanone were detected only in minute amounts, which normally dominate in fungal volatile pattern. This is probably due to the fact that the growth phase of the fungus was stopped, which might relate to release of these typical fungal odours (Thakeow et al. 2007). In C. cinerea, it was found that the 
quantity of 1-octen-3-ol was decreased during whole life cycle development, from primary primordia to the autolytic fruiting body (Thakeow et al. manuscript in preparation). Many heteroatom-containing compounds were detected, probably contributing to the stink odour of the autolytic fungi, like 3-furaldehyde, benzaldehyde, N,N-dimethyl formamide, benzoxazol, indole, dimethyl disulphide, and dimethyl trisulphide. The last two compounds were found as a volatile from spoiled meat (Brown 1982) and arum plant (Kite and Hetterschieid 1997).

During growth development of fungi, they differently released volatiles as revealed in C. cinerea (Thakeow et al. manuscript in preparation) and Tuber borcbii (Zeppa et al. 2004). The volatiles could be by-products of metabolism that the fungivorous insects use for their host identification. Besides that the volatiles could be released in order to attract the insects for involving their reproduction like when they are autolysis, dimethyl disulphide and dimethyl trisulphide, which smells similar to spoiled meat (Gill 1982), is released to catch the attention of flies. In this study, it was demonstrated that the fly can electrophysiologically and reproducibly perceive the volatiles released from autolysis Coprinus and Coprinopsis species fruiting bodies. This remarkable selectivity could lead to the development of VOC-based early warning system for fungal-decayed meat as it has been done in fungal infested potatoes (Schütz et al 1999).

\section{Acknowledgement}

I would like to thank to Dr. Pavel Plašil, Forest Zoology and Forest Conservation, Büsgen Institute, George-August-University Göttingen for the Suillia mikii fly identification, and Prof. Ursula Kües and Wassana Chaisaena, Section of Molecular Wood Biotechnology, Büsgen Institute, George-August-University Göttingen for providing Coprinopsis cinerea cultures.

\subsection{References}

Akiyama K, Matsuzuki K-I, Hayashi H. 2005. Plant sesquiterpenes induce hyphal branching arbuscular mycorrhizal fungi. Nature 435: 828-827. 
Brown MH (Ed). 1982. Meat Microbiology. Applied Science Publishers, London \& New York. Ewen RJ, Jones PRH, Ratcliffe NM, Spencer-Phillips PTN. 2004. Identification by gas chromatography-mass spectrometry of the volatile organic compounds emitted from the wood-rotting fungi Serpula lacrymans and Coniophora puteana, and from Pinus sylvestris timber. Mycological Research 108: 806-814.

Fäldt J, Jonsell M, Nordlander G, Borg-Karlson KA. 1999. Volatiles of bracket fungi Fomitopsis pinicola and Fomes fomentarius and their functions as insect attractants. Journal of Chemical Ecology 25: 567-589.

Gill CO. 1982. Microbial interaction with meats. In: Brown MH (Ed). Meat Microbiology. Applied Science Publishers, London \& New York. pp. 225-264.

Kaissling KE, Thorson J. 1980. In: Receptors for Neurotransmitters, Hormones and Pheromone in Insects. Satelle DB, Hall LM, Hildebrand JG (Eds).Elsevier/NorthHolland Biomedical Press, Amsterdam. pp. 261-281.

Keshri G, Challen M, Elliott T, Magan N. 2003. Differentiation of Agaricus species and other homobasidiomycetes based on volatile production patterns using an electronic nose system. Mycological research 107: 609-613

Kite GC, Hetterschieid WLA. 1997. Inflorescence odours of Amorphophallus and Pseudodracontium (Araceae). Phytochemistry 46: 71-75.

Kües U. 2000. Life history and development processes in the basidiomycete Coprinus cinereus. Microbiology and Molecular Biology Reviews 64: 316-353.

Lawrence JF. 1989. Mycophagy in the Coleoptera: Feeding strategies and morphological adaptations. In: Insect-fungus interactions. Wilding N, Collins NM, Hammond PM, Webber JF. Academic press, London. pp. 2-23.

Pawliszyn J. 1997. Solid phase microextraction: theory and practice. VCH, New York.

Schütz S, Weißbecker B, Koch UT, Hummel HE, 1999. Detection of volatiles released by diseased potato tubers using a biosensor on the basis of intact insect antennae. Biosensor and Bioelectronics 14: 221-228.

Ševčik J. 2001. Diptera (excluding Macetophilidae s. str.) associated with fungi in Czech and Slovak Republics: a survey of rearing records from 1998-2000. Acta Universitatis Carolinae Biologica 45: 157-168.

Thakeow P, Angeli, S, Weißbecker B, Schütz S. 2008. Antennal and behavioural responses of Cis boleti to fungal odour of Trametes gibbosa. Chemical Senses 33: 379-387.

Thakeow P, Chaisaena W, Kües K, Schütz S. Monitoring of volatile organic compounds released from Coprinopsis cinerea fruiting body development. Manuscript in preparation.

Thakeow P, Holighaus G, Schütz S. 2007. Volatile compounds for wood assessment. In: Kües U. (Ed). Wood production, wood technology and biotechnological impacts. Universitätsverlag Göttingen, Göttingen. pp. 197-228.

Weissbecker B, Holighaus G, Schütz S. 2004. Gas chromatography with mass spectrometric and elecroantennographic detection: analysis of wood odorants by direct coupling of insect olfaction and mass spectrometry. Journal of Chromatography A. 1056: 209-216.

Zeppa S, Gioacchini MA, Guidi C, Cuescini M, Pierleni R, Zambonelli A, Stocchi V. 2004. Determination of specific volatile organic compounds synthesised during Tuber borchii fruit body development by solid-phase microextraction and gas chromatography/mass spectrometry. Rapid Communications in Mass Spectrometry 18: 199-205.

Zhang Z, Yang MJ, Pawliszyn J. 1994. Solid-phase microextraction. Analytical chemistry. 66: $844 \mathrm{~A}-853 \mathrm{~A}$. 




\section{CHAPTER 8}

Fungivorous Insect Antennae as Biosensors for Wood-rotting Fungi 



\subsection{Abstract}

Quality assessment evaluating the feedstock for wood material production requires a quick and selective detection of fungal infection. A biosensor based on intact insect antenna was tested with beech wood samples infected by Trametes versicolor as a proof of principle. The fungivorous insect, Cis boleti, is evolutionarily optimised for detecting fungi growing on wood. The antenna of $C$. boleti was shown to perceive the typical fungal odour, 1-octen-3ol with high selectivity and a sensitivity of down to $5 \mathrm{ng} \mathrm{ml}^{-1}$ in air. In order to increase the reliability of the antennal response, a biosensor system using the superposition method was employed. The short response time of the antenna enabled the design of a standard protocol to measure fungal volatiles including continuous recalibration of the biosensor system. Using this internal recalibration yielded reproducible responses to the fungal marker volatile compound. An online assessment of wood samples was possible with a throughput of one sample per minute. The life time of $C$. boleti antenna was up to one day.

Keywords: Insect antenna, Cis boleti, GC-EAD, biosensor, VOCs, beech wood, Trametes versicolor 


\subsection{Introduction}

Traditional methods to assess fungal-infected wood are based on visual inspection and physical property testing. Visual inspection is often costly and not reliable enough to meet the high quality requirements for feedstock of certain wood materials. Physical property testing is destructive and can be performed only on selected samples. A complementary method for quality control could be the examination of volatile organic compounds (VOCs) resulting from the metabolism of growing fungi on wood substrate. Techniques based on fungal VOC detection are a promising alternative for specific, sensitive, and rapid routine diagnosis directly from wood samples. The advantage of these methods is that they are working even if there are no visible symptoms of fungal infection because of early developmental stage or obstruction of visible inspection by bark and wood structure. Sampling the air over wood logs allows a high throughput testing without inflicting damage to the wood logs. VOCs of fungal rotted wood are frequently containing 1-octen3-ol as a characteristic marker compound of fungal activity (Combet et al. 2006; Thakeow et al. 2006, 2007). Moreover, additional VOCs of fungal-rotted wood are affected by the infecting species, the wood substrate, and the developmental stage of the fungi (Thakeow et al. 2006, 2007).

Fungivorous insects need to locate and identify suitable wood degrading fungi as nutrients for their offspring. Thus, fungivorous beetles like Cis boleti are evolutionarily optimised for detecting wood degrading fungi. Despite the fact that these beetles are able to distinguish even different species of wood degrading fungi, their antennae respond to the general marker compound of fungal infection, 1-octen-3-ol with high sensitivity and selectivity (Thakeow et al. 2008). Insect antennae of $C$. boleti are therefore utilised as biocomponents of a biosensor on the basis of intact insect antenna. Detection of VOCs by means of a biosensor is a promising technology providing a fast, non-destructive, and selective screening tool. Several biosensors have been developed and applied on this basis as, for example a field measurement system of pheromone concentration (Koch et al. 1997, 2002; Sauer et al. 1992), a smoke detector (Schütz et al. 1999a), and a biosensor for 
the detection of potatoes infected by Phytophtora infestans in potato storage (Schütz et al. 1999b).

This study is designed to examine the feasibility of using C. boleti antenna as a biocomponent in a biosensor for the detection of fungal infection in wood.

\subsection{Materials and methods}

\subsubsection{Cis boleti}

The fruiting bodies of the wood rotting fungus Trametes gibbosa (Basidiomycete; Polyporaceae) colonised with $C$. boleti were collected from Königsbuche, a natural forest protection area near Göttingen, Germany. In this area T. gibbosa is abundant and is colonised by Ciid beetles with high rates. The colonised fruiting bodies were stored in a dark room at $10^{\circ} \mathrm{C}$ and were sprayed with tap water in order to maintain humidity.

\subsubsection{Electrophysiological response of $C$. boleti to 1-octen-3-ol}

\subsubsection{Response of $C$. boleti to 1-octen-3-ol}

In this experiment, gas chromatography-mass spectrometry/electroantennographic detection (GC-MS/EAD) was used for examining the perception of C. boleti to 1-octen-3ol in different concentration. 1-octen-3-ol (Merck, Darmstadt, Germany) was dissolved in pentane (Merck, Darmstadt, Germany) with different concentration (0.01, 0.1 and $\left.1 \mathrm{~g} \mathrm{l}^{-1}\right)$. One $\mu$ of each solution was injected to the injection port $\left(250^{\circ} \mathrm{C}\right)$ of a gas chromatograph (HP 6890N, Agilent Technologies, Paolo Alto, USA) equipped with an INNOWAX column (Agilent Technologies, Paolo Alto, USA) with a dimension of $30 \mathrm{~m} \times 0.25 \mathrm{~mm}$ i.d., $0.25 \mu \mathrm{m}$ film thickness. The temperature program started at $50^{\circ} \mathrm{C}$, held for $1.5 \mathrm{~min}$, and heated up to $250^{\circ} \mathrm{C}$ with a heating rate of $6.5^{\circ} \mathrm{C} \mathrm{min}^{-1}$. The carrier gas was helium, at a flow rate of $1.0 \mathrm{ml} \mathrm{min}{ }^{-1}$. The gas chromatographic column was split into to two paths (i) to the mass spectrometer (MS) and (ii) to the electroantennographic detector (EAD). Two 
pieces of deactivated capillary were connected to a Graphpack 3D/2 flow splitter (Gerstel, Mülheim, Germany), one capillary ( $1 \mathrm{~m}$ x $0.1 \mathrm{~mm}$, i.d.) directing to the MS and the other $(1 \mathrm{~m} \times 0.15 \mathrm{~mm}$, i.d.) directing to an olfactory detector port modified to interface to the EAD (ODP-2, Gerstel, Mülheim an der Ruhr, Germany), mass spectrometric analysis by MS 5793 (Agilent Technologies, Paolo Alto, USA) was carried out with the mass scan range of $20-400 \mathrm{amu}$, source temperature $230^{\circ} \mathrm{C}$ and EI mode at $70 \mathrm{eV}$. For preparation, one antenna of male C. boleti was cut and placed in an antenna holder both ends immersing in Ringer solution (Kaissling and Thorson, 1980), leaving the middle part of antenna exposed to volatile compounds eluted from the GC column. More detail of GCMS/EAD had been fully described by Weißbecker (Weissbecker et al. 2004).

For dose-response measurement, a dilution series of 1-octen-3-ol (Merck, Darmstadt, Germany) from $10^{-6}$ to $10^{-3}$ was prepared in paraffin oil (Uvasol®, Merck, Darmstadt, Germany). Small pieces of $18-\mathrm{cm}^{2}$ filter paper (Schleicher \& Schuell, Dassel, Germany) were put into $10 \mathrm{ml}$ glass syringes (Poulten \& Graf GmbH, Wertheim, Germany). Then, $200 \mu$ l of the standard dilution or paraffin oil (control) was spread on the filter paper. The test compound evaporated and accumulated inside the syringe at a concentration proportional to the concentration of the substance in the solution and its vapour pressure according to Henry's law. A reproducible 5-ml volume was puffed over the antenna for stimulation (Schütz et al. 1999b).

\subsubsection{Evaluation of Antennal Performance}

The antennal longevity of $C$. boleti both male and female was assessed. The insect antenna was prepared in the same procedure as mentioned in 2.2. Afterwards, it was periodically tested with the standard 1-octen-3-ol at dilution of $10^{-4}$ at 10, 20, 30 and 60 min after the antenna excision. The antennal responses to the standard were recorded. 


\subsubsection{Biosensor System}

The experiment was performed with the portable biosensor system, previously jointly developed with Prof. Dr. Uwe T. Koch and his co-workers, University Kaiserslautern, Germany (Koch 1990). It is a robust and portable EAG system for pheromone measurement. The machine was described in Färbert et al. 1997. In our experiment, this instrument was modified from the original setting by adding the test chamber part after the filter as shown in Figure 8-1. The original instrument was constructed without the part indicated as number (2). The test specimen, e.g. fungal infested wood could be placed inside. When the experiment was carried out, a pump (8) sucked down the air which is filtered through the activated carbon (1). In the mean time, the VOCs of the test chamber move through the mixing chamber to the biosensor-head. The biosensor- head contains the antenna holder chamber (7) and the antenna holder (8). The electropotential response of the detecting antenna to VOCs is transferred from the EAG output (10) to the amplification and recording unit.

The response of $C$. boleti antenna to a $\left(0.5 \times 0.5 \times 1.0 \mathrm{~cm}^{3}\right)$ sample of fungal infested wood in the portable EAG system was preliminary investigated. The dilution series of 1octen-3-ol (Merck, Darmstadt, Germany) in paraffin oil (Uvasol ${ }^{\circledR}$, Merck, Darmstadt, Germany) were prepared from $10^{-4}$ to $10^{-2}$, and $200 \mu$ of each solution was spread on a filter paper housed inside the Teflon-barrel which was placed in the syringes, parts numbers 3, 4 and 5 in Figure 8-1, respectively. 


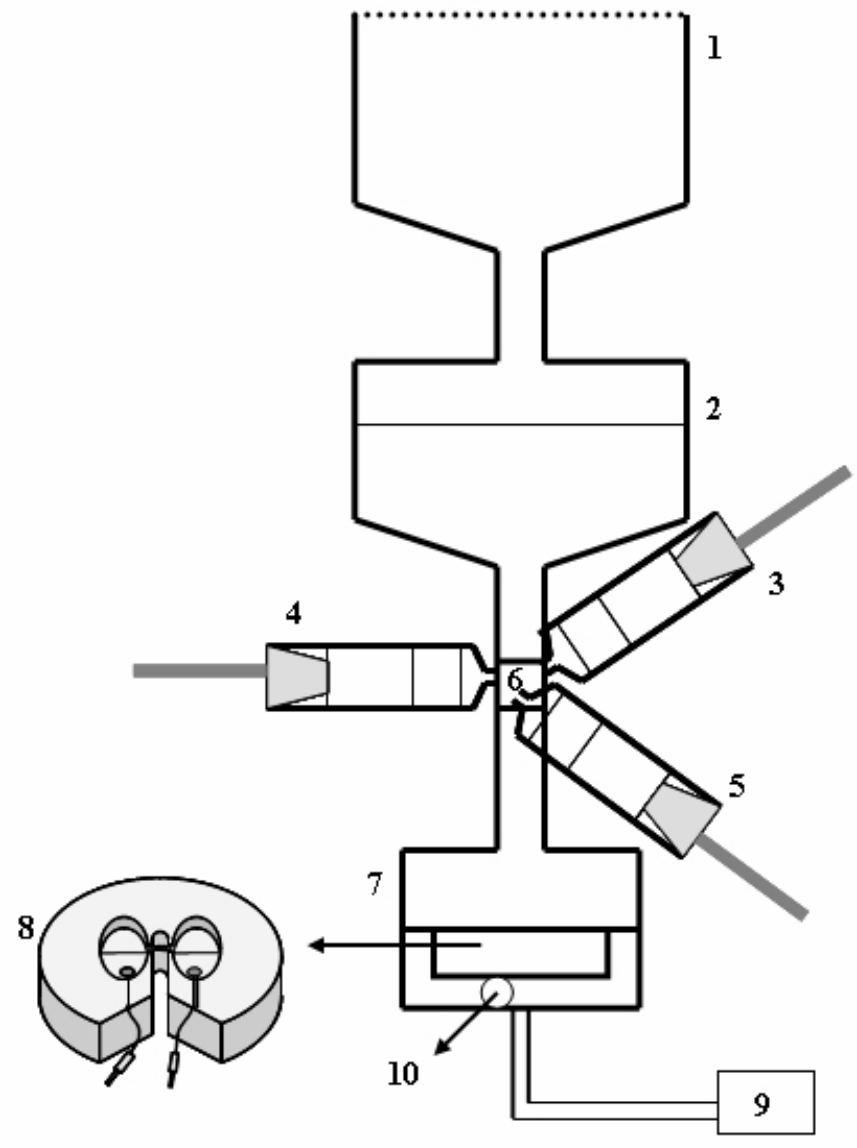

Figure 8-1 Schematic of EAG system. (1) Filter filled with activated charcoal, (2) Specimen chamber, (3, 4 and 5) Syringes containing Teflon barrel filled with filter paper soaked with compound-paraffin oil, (6) Mixing chamber, (7) Antenna holder chamber, (8) Antenna holder, (9) Pump, and (10) EAG Signal output. 


\subsection{Results}

Our previous study showed that $C$. boleti consistently responded to 1-octen-3-ol extracted from it host fungus Trametes gibbosa (Thakeow et al. 2008). This compound is commonly present in fungi and generally known as a mushroom odour (Tressl et al. 1982; Combet et al. 2006). Therefore, this fungivorous insect was investigated for the feasibility to be a biocomponent in biosensor used for monitoring fungal infested wood.

\subsubsection{Electrophysiological response of $C$. boleti to 1-octen-3-ol}

\subsubsection{Response of C. boleti to 1-octen-3-ol}

By using GC coupled with MS/EAD for testing the response of $C$. boleti to 1-octen-3-ol, it was shown that the insect responded well and consistently to this compound. The GCMS/EAD chromatograms (Figure 8-2) depicted a response of $C$. boleti antenna responded to 1 -octen-3-ol $(5 \mathrm{ng})$ at the retention time of 12.38 and $12.50 \mathrm{~min}$, for MS and EAD, respectively. The dose-response curves in Figure 8-3 demonstrated the sensitivity of the antennae to 1-octen-3-ol as a marker compound for a fungal-infested wood. The female and male beetles showed similar response to different doses, namely, the higher the dose, the higher the response. However, the females tended to responded to 1-octen-3-ol stronger than males.

\subsubsection{Evaluation of Antennal Performance}

In order to assess the suitability for a practical application, the reproducibility and longevity of the response of the antenna to 1-octen-3-ol was tested. As depicted in Figure 8-4, the female insects showed higher EAG potential than the male insects throughout the $60 \mathrm{~min}$ after the antennae were cut. After $10 \mathrm{~min}$ of excision, the response of females was $0.30 \pm 0.06 \mathrm{mV}$ and of males was $0.27 \pm 0.03 \mathrm{mV}$. After two injections at 20 and $30 \mathrm{~min}$, the antennae were left without any injection of 1-octen-3-ol. At $60 \mathrm{~min}$, the response was examined again, it revealed that the female response maintained $(0.28 \pm 0.06 \mathrm{mV})$, while the 
male response was decreased $(0.18 \pm 0.03 \mathrm{mV})$. The female antenna yielded consistent responses up to 24 hours of permanent measurement use.

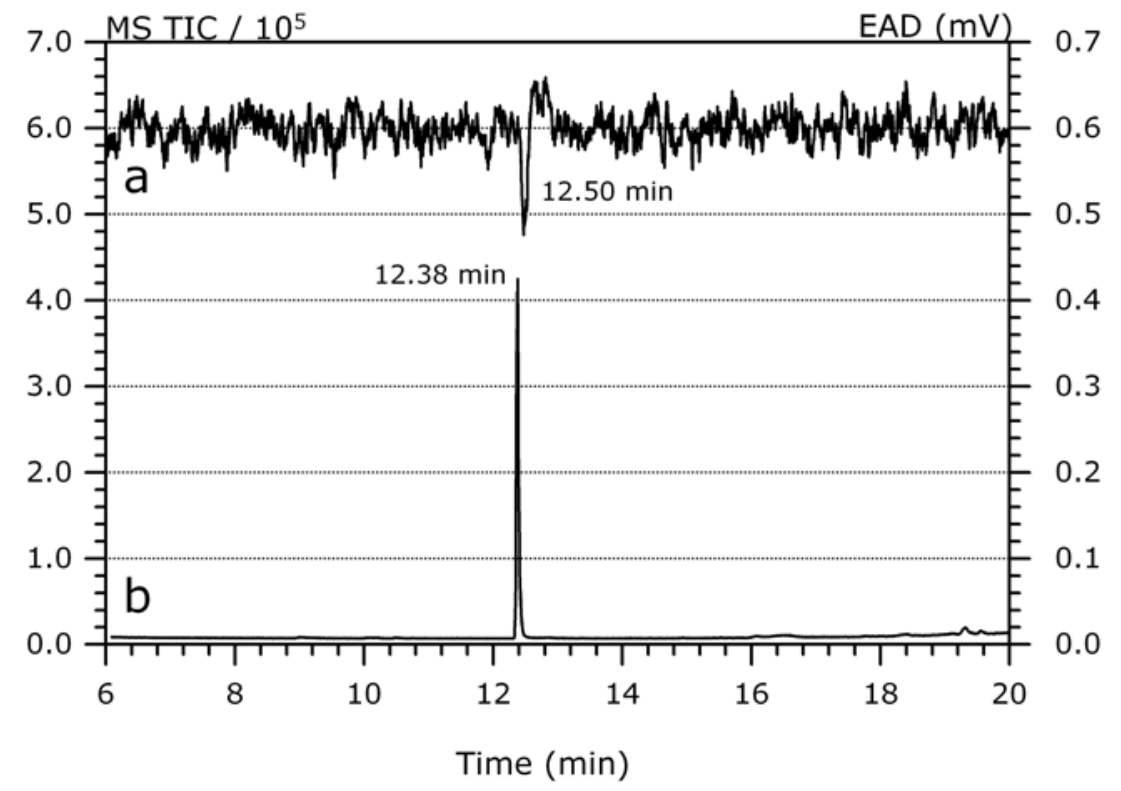

Figure 8-2 An example of gas chromatography (CG) - mass spectrometry (MS)/ electroantennographic detection (EAD) chromatograms of $C$. boleti (male) response to $5 \mathrm{ng}$ of 1-octen-3-ol. a: EAD, b: MS and TIC: total ion current. 


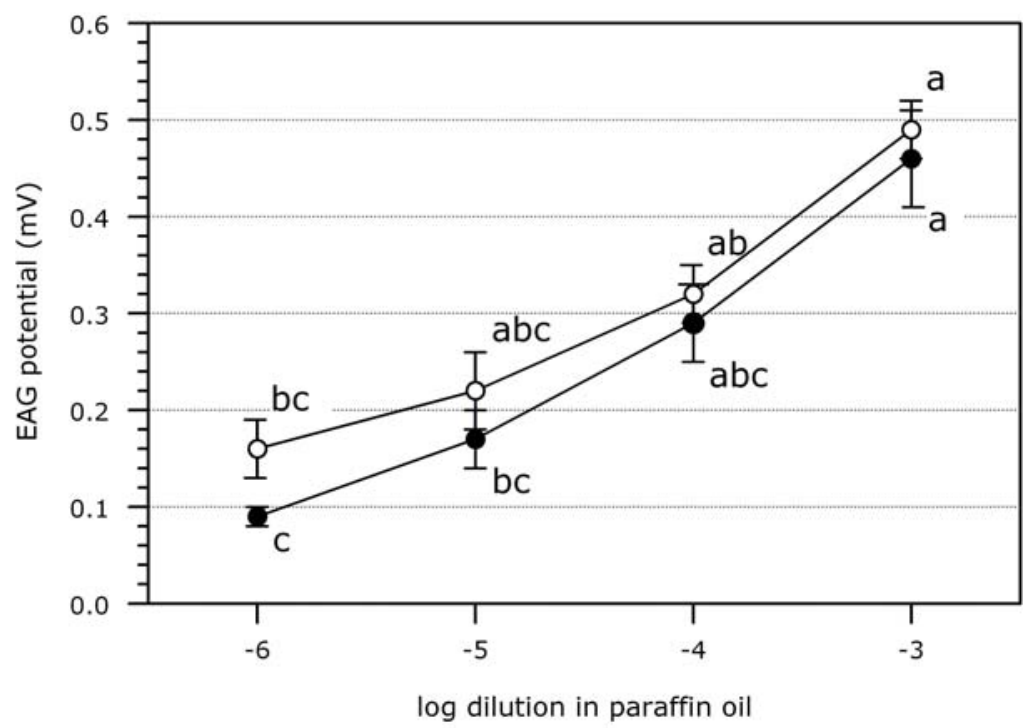

Figure 8-3 Dose-response curves of male $(\bullet)$ and female (०) C. boleti to 1-octen-3-ol. Value $=$ mean \pm SE. Different letters indicate significant differences between samples.

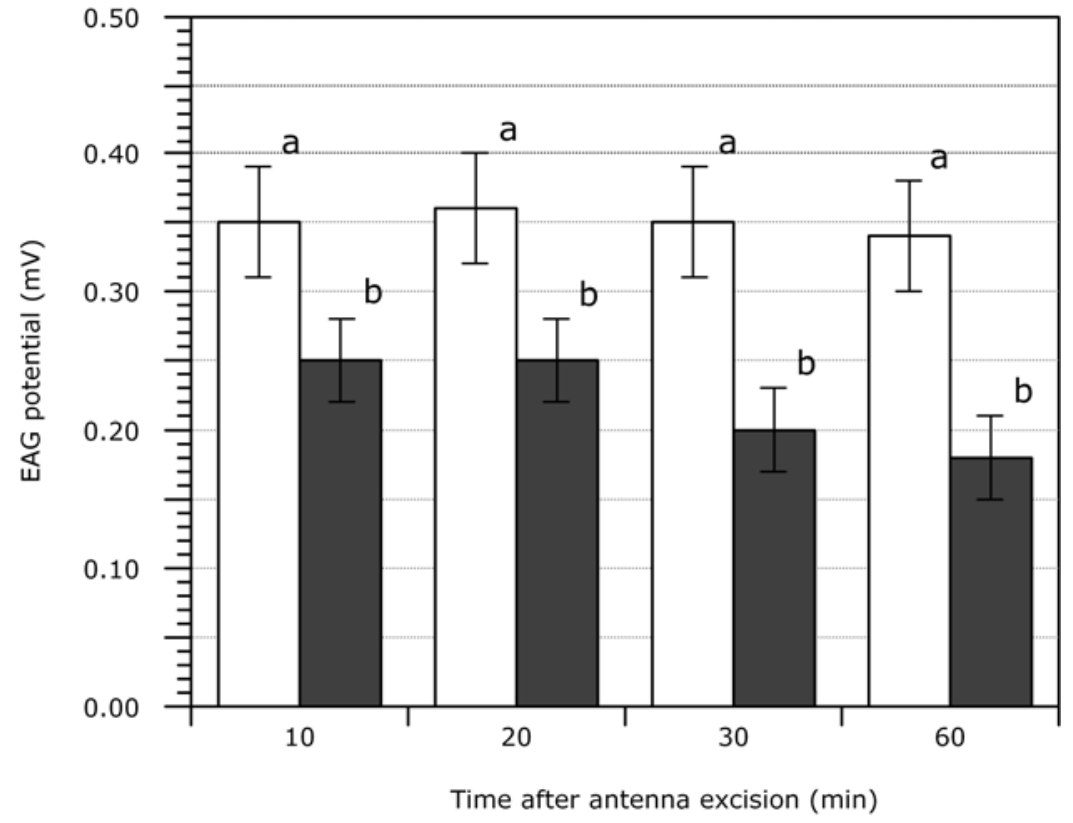

Figure 8-4 EAG responses (mean \pm SE) of male ( $\square)$ and female $(\square)$ C. boleti to 1-octen-3-ol at a dilution of $10^{-4}(\mathrm{n}=5$ for each sex). Different letters indicate significant differences between samples. 


\subsubsection{C. boleti antennal response using the portable biosensor system}

A proof of principle experiment employing C. boleti antenna as a biocomponent in the portable biosensor system for detecting fungal infestation on wood specimen was carried out. C. boleti antenna was excised and placed in an antenna holder, which was enclosed antennal holder chamber. This part was later connected to the portable biosensor system (Figure 8-1). The antennal response to a standard compound 1-octen-3-ol at different dilutions, $10^{-4}, 10^{-3}$ and $10^{-2}$, was measured. The $10^{-4}$ dilution of 1 -octen-3-ol did not elicit clear responses comparing to the other two dilutions. The $10^{-3}$ and $10^{-2}$ dilutions of 1 octen-3-ol repeatedly elicited C. boleti antennal responses of $1.31 \pm 0.10$ and $3.08 \pm 0.14 \mathrm{mV}$, respectively. After that a wood specimen (beech rotted with Trametes versicolor), was put in the specimen chamber and the pump (flow rate $20 \mathrm{l} \mathrm{h}^{-1}$ ) was started passing the air inside the chamber over the mounted antenna. In the meantime, the calibrating standard puffs of 1-octen-3-ol were injected in the order to measure the 1-octen-3-ol concentration released by the wood sample and also passed over the antenna. This superposition technique was shown for the first time with a fungivorous insect. Under the atmosphere of fungalinfested wood volatiles, containing 1-octen-3-ol, the antennal response of $C$. boleti to the standard dilutions of 1-octen-3-ol became lower than before. The responses were reduced to be $1.12 \pm 0.15$ and $2.78 \pm 0.31 \mathrm{mV}$ for $10^{-3}$ and $10^{-2}$ dilutions of 1 -octen-3-ol, respectively. The antennal responses between with and without infected-beech wood were significantly different $\left[\mathrm{F}(1,10)=6.74, \mathrm{p}<0.1\right.$ and $\mathrm{F}(1,10)=17.66, \mathrm{p}<0.01$ for dilutions of $10^{-3}$ and $10^{-2}$, respectively], demonstrating a reliable detection of fungal infected wood.

\subsection{Discussion}

There have been several approaches aiming to investigate the infestation of fungi on wood, for example, Fourier-transformed infrared spectrometry (FTIR) (Naumann et al. 2005), Matrix Assisted Laser Desorption Ionization Time-of-flight Mass Spectrometry (MALDI-TOF-MS) (Schmidt and Kallow 2005), polymerase chain reaction (PCR) (Parfitt et al. 2003; Guglielmo et al. 2007), and terminal restriction fragment length polymorphism 
(T-RFLP) (Råberg et al. 2005). These techniques are efficient in identification of fungal species infecting wood samples, but not appropriate for quick and non-destructive screening. Therefore, techniques based on fungal VOC detection on the basis of intact insect antennae are a promising alternative for specific, sensitive, and rapid routine diagnosis directly from wood samples. Testing by antenna-based biosensor has been achieved in several fields, especially in agriculture (Milli et al. 1997; Schöning et al. 1998; Schroth et al. 1999; Schütz et al. 1997, 1999; Sevonkaev and Katz 2008).

This work demonstrated that $C$. boleti antenna can be used as a biocomponent in the portable biosensor system for sensing 1-octen-3-ol as a general indicator of fungal activity in wood samples. This biosensor approach might complement visual inspection of feedstock for wood material production. Moreover, an identification of fungal species or groups of fungal species might become feasible by this biosensor technique employing insects responding selectively to species specific fungal volatiles like sesquiterpene (Thakeow et al. 2006). Thus, this quick and damage free screening tool might complement the aforementioned more sophisticated methods of fungal identification in wood samples. Despite the fact that the biosensor system demonstrated a high selectively and high sensitivity to important fungal compounds it is not ready yet for industrial routine application. First of all, the limited life time of the biocomponent is an obstacle to feedstock monitoring. Transferring important principles of stabilisation, prefiltering and recognition from insect olfaction to other technologies will be essential for bringing bioinspired sensor technology into industrial application (Eberheim et al. 2004; Thakeow et al. 2007).

\subsection{References}

Combet E, Henderson J, Eastwood DC, Burton KS. 2006. Eight-carbon volatiles in mushrooms and fungi: properties, analysis, and biosynthesis. Mycoscience 47: 317-326.

Eberheim A, Schieberle P, Schütz S, Kohl D. 2004. Fire recognition based on new technologies. Abstracts of the XXII International Conference of Entomology in Brisbane, Australia 15.-21. August 2004 (unpaged). 
Färbert P, Koch UT, Färbert A, Staten RT, Cardé RT. 1997. Pheromone concentration measured with EAG in cotton fields treated for mating disruption of Pectinophora gossypiella (Lepidoptera: Gelechiidae). Environmental Entomology 26: 1105-1116.

Guglielmo F. Bergemann SE, Gonthier P, Nicolotti G, Garbelotto. 2007. A multiplex PCR-based method for the detection and early identification of wood rotting fungi in standing trees. Journal of Applied Microbiology 103: 1490-1507.

Kaissling KE, Thorson J. 1980. Receptors for Neurotransmitters, Hormones and Pheromones in insects, in Satelle DB, Hall LM \& Hildebrand JG (Eds). Elsevier/North-Holland Biomedical Press. 261 pp.

Koch UT, Cardé AM, Cardé RT. 2002. Calibration of an EAG system to measure airborne concentration of pheromone formulated for mating disruption of the pink bollworm moth, Pectinophora gossypiella (Saunders) (Lep., Gelechiidae). Journal of Applied Entomology 126: 431-435.

Koch UT, Lüder W, Clemens S, Cichon LI. 1997. Pheromone measurements by field EAG in apple orchards. Technology Transfer in Mating Disruption, IOBC wprs Bulletin 20: 181190.

Koch UT. 1990. A portable EAG system for measurement of pheromones in the field. In: Proceedings of the $200^{\text {th }}$ National Meeting of the American Chemical Society, Division of Agricultural and Food Chemistry, Washington, DC, 26-30 August 1990. Abstract 31.

Milli R, Koch UT, de Kramer JJ. 1997. EAG measurement of pheromone distribution in apple orchards treated for mating disruption of Cydia pomonella. Entomologia Experimentalis et Applicata 82: 289-297.

Naumann A, Navarro-Gonzalez M, Peddireddi S, Kues U, Polle A. 2005. Fourier transform infrared microscopy and imaging: detection of fungi in wood. Fungal Genetics and Biology 42: 829-35.

Parfitt D, Hynes J, Rogers JH, Boddy L. 2003. New PCR assay detects rare tooth fungi in wood where traditional approaches fail. Mycological research 109: 1187-1194.

Råberg U, Höberg NOS, Land CJ. 2005. Detection and species discrimination using rDNA TRFLP for identification of wood decay fungi. Holzforschung 59: 696-702.

Schmidt O, Kallow W. 2005. Differentiation of indoor wood decay fungi with MALDI-TOF mass spectrometry. Holzforschung 59: 374-377.

Sauer AE, Karg G, Koch UT, de Krammer JJ, Milli R. 1992. A portable EAG system for the measurement of pheromone concentrations in the field. Chemical Senses 17: 543-553.

Schöning MJ, Schütz S, Riemer A, Weißbecker B, Steffen A, Kordos P, Lüth H, Hummel HE. 1998. A BioFET on the basis of insect antennae. Sensor Actuators B 47: 234-237.

Schroth P, Schöning MJ, Kordos P, Lüth H, Schütz S, Weißbecker B, Hummel HE. 1999. Insect-based BioFETs with improved signal characteristics. Biosensors and Bioelectronics 14: 303-308.

Schütz S, Weißbecker B, Hummel HE, Apel K-H, Schmitz H, Bleckmann H. 1999a. Insect antennae as a smoke detector. Nature 398: 298-299.

Schütz S, Weißbecker B, Koch UT, Hummel HE. 1999b. Detection of volatiles released by diseased potato tubers using a biosensor on the basis of intact insect antennae. Biosensors \& Bioelectronics 14: 221-228.

Schütz S, Weißbecker B, Schroth P, Schöning MJ. 2001. Linkage of inanimate structures to biological systems - Smart materials in biological micro- and nanosystems. In: Hoffmann $\mathrm{KH}$. (Ed.) Lecture notes in computational science and engineering. Springer-Verlag, Heidelberg-New York. pp. 215-221. 
Sevonkaev IV, Katz E. 2008. Biosensors based on immobilized insects fragments. Journal of Solid State Electrochemistry 12: 7-14.

Thakeow P, Angeli, S, Weißbecker B, Schütz S. 2008. Antennal and behavioural responses of Cis boleti to fungal odour of Trametes gibbosa. Chemical Senses 33: 379-387.

Thakeow P, Holighaus G, Schütz S. 2007. Volatile compounds for wood assessment. In: Kües U. (Ed). Wood production, wood technology and biotechnological impacts. Universitätsverlag Göttingen, Göttingen. pp. 197-228.

Thakeow P, Weißbecker B, Schütz S. 2006. Volatile organic compounds emitted from fungalrotting beech (Fagus sylvatica). Mitteilungen der Deutschen Gesellschaft für allgemeine und angewandte Entomologie 15: 157-160.

Tressl R, Bahri D, Engel K-H. 1982. Formation of eight-carbon and ten-carbon components in mushrooms (Agaricus campestris). Journal of Agricultural and Food Chemistry 30: 89-93.

Weissbecker B, Holighaus G, Schütz S. 2004. Gas chromatography with mass spectrometric and electroantennographic detection: analysis of wood odour by direct coupling of insect olfaction and mass spectrometry. Journal of Chromatography A 1056: 209-216. 



\section{CHAPTER 9}

General Discussion 



\subsection{General discussion}

Wood-decaying fungi are the most important microorganisms that can colonize and degrade wood and wood products (Carroll and Wicklow 1992; Hoff et al., 2004) causing economic losses in wood industry (Zabel and Morrell 1992). For that reason, several efforts have been undertaken to prevent wood degradation by fungi in several processes (Hill 2006). Moreover, several efforts were done to develop standard testing methods to evaluate and to predict the degradability of natural wood as well as of wood (Eaton and Hale 1993). The

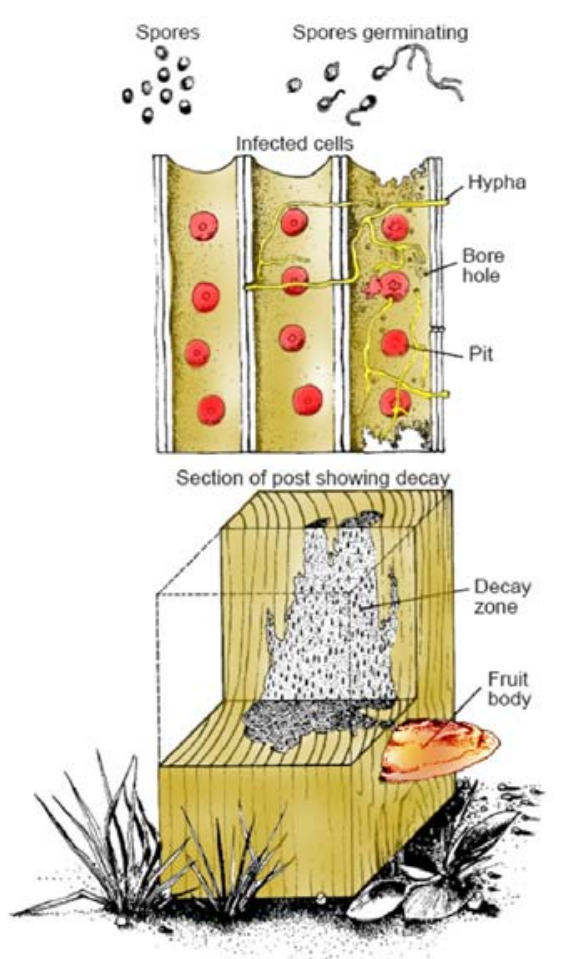

Figure 9-1 The cycle wood-decaying fungi (top to bottom). Thousands of spores produced in a fruiting body are distributed by wind or insects. On contacting moist, susceptible wood, they germinate to create new infections in the wood cells. In time, serious decay develops that may be accompanied by formation of new fruiting bodies (after Highley 1999). traditional testing methods are generally based on physical properties, for example, visual inspection, strength, weight loss, and more precisely by the so-called modulus of elasticity (MOE) and modulus of rupture (MOR) (Green et al. 1999; Curling et al. 2002; Goodell et al. 2003). The changes of those properties are the consequence of fungal degradation (Figure 9-1.).

The evaluation of wood decay by visual inspection is a subjective technique that does not detect early decay. For instance, it has been described that early stages of brown rot decay, not detectable with visual inspections, already caused losses in strength in the order of $70 \%$ of $\mathrm{MOE}$ (Wilcox 1978). However, the alteration of the wood physical properties occurs after a period of time from infection, which may last for several weeks. 
Therefore, there is a need of new approaches to test wood decay during the first, critical stages of fungal infections. One promising methodology regards the possibility to detect volatile organic compounds released by the fungal metabolisms or resulting from the interaction of the fungal compounds with wood metabolites. These methods would provide a fast and non-destructive measurement and could be a complement to the traditional testing techniques. With the aim to achieve this objective, we performed several experiments to define and develop such methodology. Several investigations were carried out measuring the volatile compounds released from different decay fungi and fungalwood specimens. To study the feasibility of using VOCs as marker compounds for fungus-infested wood we developed a new olfactory-based biosensor where the biocomponent is the antenna of fungivorous insects which are highly sensitive and specialised in detecting the volatile compounds of fungal-infested wood.

\subsection{Volatile sampling techniques}

Volatile identification is strongly dependent on sampling techniques. For our investigation we adopted two sampling methods in order to detect and characterise the headspaceVOCs (HS-VOCs) of our samples. The active sampling was carried out by circulating the HS VOCs through activated charcoal and the porous polymer, poly(oxy-2,6-diphenyl-1,4phenylene), known as Tenax-TA ${ }^{\mathrm{TM}}$ (Gerstel, Germany). The passive sampling was carried out by suspending SPME fibres in the headspace, where the volatiles adsorb to the fibre according to their physical and chemical properties. It is well known that SPME has a markedly different performance than the porous polymers, resulting in different ratios of adsorbed compounds (Agelopoulos and Pickett 1998). Nevertheless, SPME is widely used in many research fields, and it has become very popular due to its simplicity in manual operation, the variety of polymer-matrixes with different affinity to volatile compounds, and the adequate performance in specified conditions (Zhang and Pawliszyn 1993; Buzzini et al. 2003; Jeleń 2003; Zeppa et al. 2004; Thakeow et al. 2006). In Chapter 7 we described 
and provided the results of two types of VOCs sampling methods, which allowed us to obtain optimised information about the released volatiles.

Sampling conditions are also important to volatile identification. For example, in case of SPME, the sampling depends on equilibrium between a volatile compound (i.e. its vapour pressure) and the fibre. Therefore, many factors like sampling temperature, humidity, sampling time, sample concentration, polymer types, and headspace volume influence the VOC patterns (Current et al. 2001; Yang et al. 2001). Therefore, all relevant parameters were monitored during SPME sampling experiments. Comparisons of results obtained under different conditions were handled with care.

\subsection{Identification of VOCs in fungi}

There are several chemical categories of VOCs released from wood, infected wood, and microorganisms (Chapter 2). Those compounds cover broad ranges of chemical classes, i.e., alcohols, aldehydes, acids, ketones, esters, sulphur (S)-containing compounds, nitrogen (N)-containing compounds and terpenoids. VOCs released are influenced by many factors, for example, stage of fungal development and substrates. Subsequently, VOCs provide information about the condition of a sample. For example, Serpula lacrymans grown on Pinus sylvestris sawdust released 1-octen-3-ol as a major compound when it was alive, while 3-methylbutanal and 2-methylbutanal were released when it was dead (Ewen et al. 2004).

In a similar way, the young fruiting body of Polyporus sulfureus released 1-octen-3-ol as a dominant compound, when it became aged, this fungal alcohol was not anymore abundantly released and 3-methylbutanoic acid was additionally detected (Wu et al. 2005). In our experiments we found that 1-octen-3-ol was highly present in fresh fungal-infected beech wood, while its relative concentration decreased in the later stages of mycelium growth, as reported in Chapter 3. In contrast to that, 3-methyl-1-butan-1-ol was released continuously during the growth stages of the T. versicolor mycelium in infected beech wood. We may notice that 3-methyl-1-butan-1-ol can be consequently oxidised to from 3- 
methylbutanal which be further oxidised to 3-methylbutanoic acid, as schematically shown in Figure 9-2. Therefore, we propose that these compounds could be involved in fungal aging processes.

We discovered that at specific developmental stages the ink cap fungus Coprinopsis cinerea released different volatile compounds. The two sesquiterpenes $\beta$-himachalene and cuparene were released during the stipe elongation and cap expansion stages, while dimethyl disulfide was released during autolytic stage, as described in Chapter 4.

\section{A}<smiles>CC(C)CCO</smiles>

3-methylbutan-1-ol

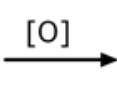

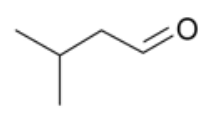

3-methylbutanal

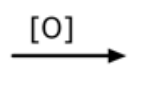

B

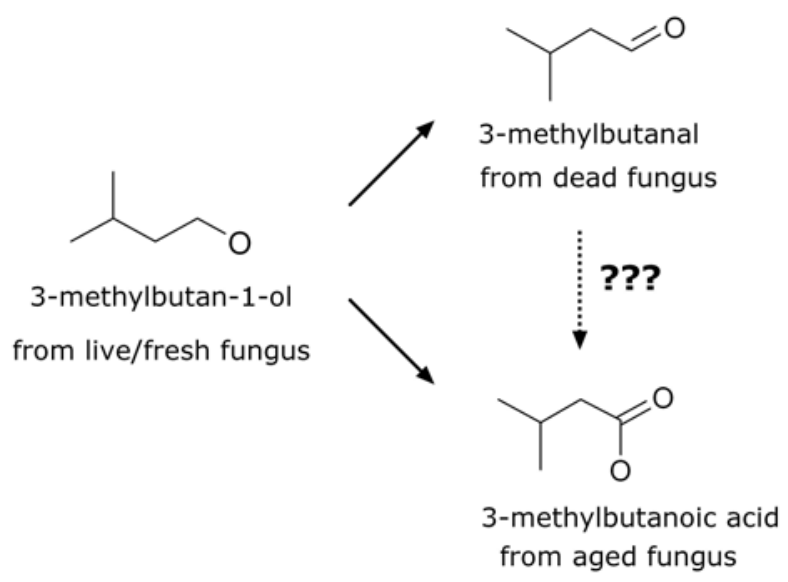

Figure 9-2 (A) Chemical oxidation of 3-methylbutan-1-ol and (B) Proposed biosynthetic relation of 3-methylbutan-1-ol, 3-methylbutanal, and 3-methylbutanoic acid at different stages of fungal development. 
These fungal-stage-related VOCs are not characteristic only of basidiomycetes but they are also present in ascomycetes. A remarkable example was given by the ascomycete Tuber borchii. Several S-containing compounds, e.g. 5-methyl-3H-1,2-dithiol-3-one, were found only in later stages of ascus spore maturation, while 1-octen-3-ol was detected only the last stage of spore maturation (Zeppa et al. 2004). In another ascomycete, Penicillium paneum, it was found that 1-octen-3-ol regulates the germination process at different developmental stages of conidia (Chitarra et al. 2004).

Nutrients and the physical environments strongly influence growth and development of fungi (Kües 2000; Chang and Miles 2004) and alter VOC patterns released (Wheatley et al. 1997; Bruce et al. 2000; Fiedler et al. 2001; Gao and Martin 2002: Gao et al. 2002, Scotter et al. 2005; Thakeow et al. 2007). Production of volatile organic compounds by Trichoderma was influenced by the type of growth media, where an aminoacid-rich media promoted the releasing of $\mathrm{N}$ - and S-containing compounds, whereas a carbohydrate-rich media promoted the releasing of alcohols, acids, aldehydes, and ketones (Bruce et al. 2004).

All these results support the hypothesis that fungal VOCs play an essential role in the regulation of fungal development and may strongly influence important ecological processes such as fungus-plant, fungus-insect and fungus-fungus interactions. Moreover, some specific volatile compounds released by fungi have antibacterial and antimicrobiological activity. An example which led to commercial applications is the endophytic fungus Muscodor albus, which released mixture of volatiles effectively inhibiting and killing certain other fungi and bacteria. The majority of these compounds were identified and an artificial mixture mimicked the antibiotic effects of the genuine fungal volatile compounds (Strobel et al. 2001; Strobel and Daisy 2003). The fact that alteration in fungal VOCs is strongly related to the developmental stage and substrate may lead to practical application. For instance, the harvesting period and the substrates used for fungal cultivation could be selectively adopted in order to obtain high-nutrient quality fungi and pharmaceutical active compounds. 


\subsection{Insect antennae as biocomponents in biosensors}

Insect olfaction is a complex system (Kanaujia and Kaissling 1985; Steinbrecht and Kasang 1972) which shows a high sensitivity and selectivity in odour perception. Insects have been able to fill a variety of ecological niches, for examples fruit flies are associated with fruits, blowflies are associated with rotten meat, fungivorous insects are associated with fungi, and bark beetles are associated with trees. This ecological diversity potentially allows making use of their antennae as biocomponents of biosensors for a large number of purposes.

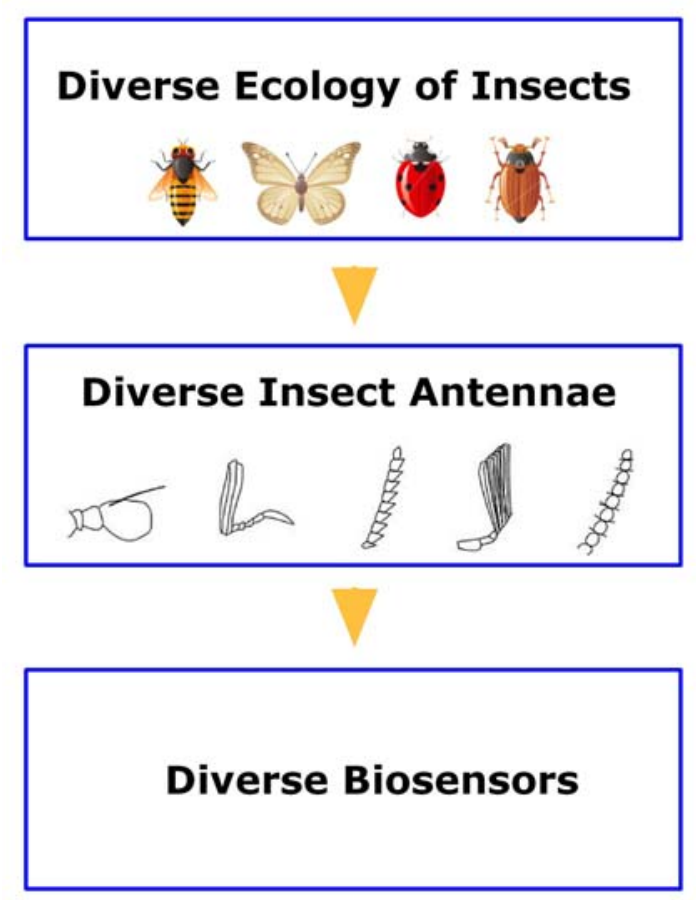

Figure 9-3 General idea of using the diversity of insect antennae as biocomponents in biosensors. 
Some insect species have been deeply studied in relation with their host selectivity. The Colorado potato beetle Leptinotarsa decemlineata (Coleoptera: Chrysomelidae) perceived VOCs released from potato plants and also infected potatoes with high sensitivity (Schütz et al. 1999a). The jewel beetle Melanopbila acuminata (Coleoptera: Buprestidae) efficiently sensed smoke form forest fire at concentration as low as a few part per billion (Schütz et al. 1999b). The bark beetles (Scolytus, Dendroctonus, Hylurgops, Trypodendron, and Tomicus) detected the suitability of their host trees for oviposition (Byer 1995).

These examples are just a few among several ones where insect olfaction was investigated in great detail. However, there have been only few cases of using insect antennae as biocomponents in biosensor devices. A review where the researches of olfactory-based biosensors were summarised in a concise and comparable way has been recently written by Sevonkaev and Katz (2007).

In our investigations we aimed to develop a fast and non destructive biosensor testing method of wood durability against decay fungi. For this reason, we chose to examine the antennal responses of two different insect species. The fungivorous beetle, Cis boleti and the fungal-associated fly, Suillia mikii, were selected as promising candidates for detecting fungal VOCs. C. boleti was able to perceive several volatile compounds of Trametes gibbosa, and remarkably the insect discriminated between the two enantiomers of 1-octen-3-ol (Thakeow et al. 2008 and Chapter 6). Therefore, a portable biosensor using the superposition method and equipped with the C. boleti antenna was constructed. The biosensor yielded reproducible responses to the fungal marker volatile compound as described in Chapter 8 . The fly $S$. mikii responded to some volatiles specifically released by the autolytic fruiting bodies of Coprinus and Coprinopsis, such as 1-undecene, 2-nonanone, dimethyl disulphide, and dimethyl trisulphide (Chapter 4). The antennal preparation of the two insects, C. boleti and S. mikii is shown in Figure 9-4. 

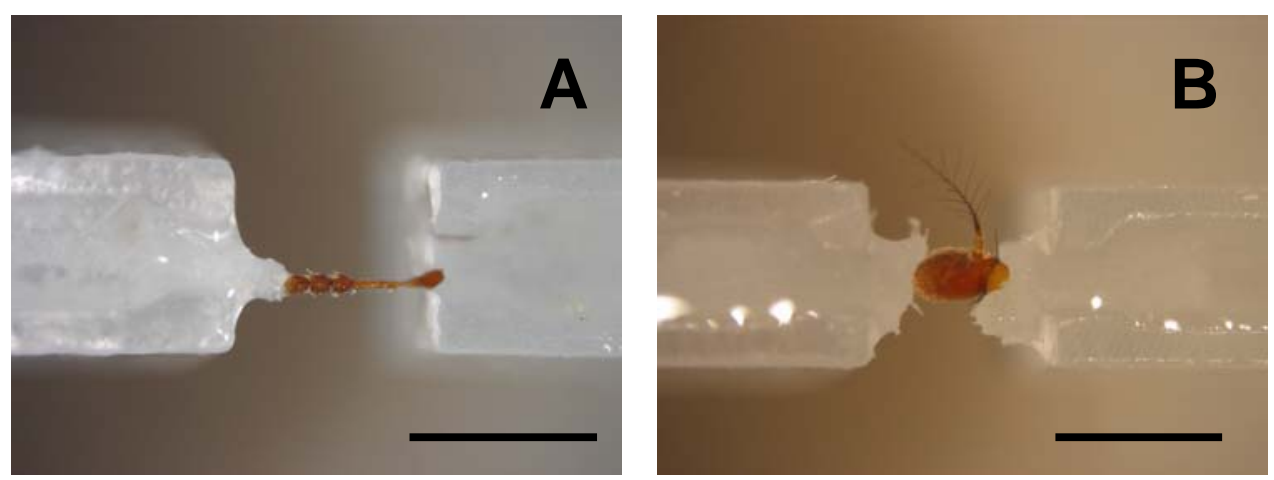

Figure 9-4 Excised insect antennae placed in EAG antennal holder. (A) Cis boleti antenna, bar: $1 \mathrm{~mm}$ and (B) Suillia mikii antenna, bar: $1 \mathrm{~mm}$.

These pioneer studies on decay wood testing with olfactory-based biosensors are very promising, since we demonstrated a high sensitivity and selectivity of the biocomponents. However, still there are some problems in detection, caused by the receptor degradation due to natural aging processes in the biocomponents, although we were able to record antennal signals up to one day after the antenna was cut from the insect. The fluctuation of the signals during measurements and the individual variability of the antenna are critical aspects of these types of biosensors. Therefore, there is a need of a frequent re-calibration system which was accomplished in our experiment by the superposition technique. However, more experiments have to be carried out before our biosensors will perform robust and consistent measurements to reach the requirements of industrial applications. Nevertheless, our work demonstrated that $C$. boleti antenna can be used as a biocomponent in the portable biosensor system for sensing 1-octen-3-ol as a general indicator of fungal activity in wood samples. 


\subsection{Conclusion and future prospectives}

In this research it was demonstrated that fungal-infected beech wood released specific volatile patterns for each tested fungal species. C8 compounds were commonly released, while sesquiterpenes were species-specifically released. Those compounds can be used as markers for fungal-infected wood, either as general or species-specific indicators of infected wood. The fungivorous beetle $C$. boleti and the fugal associated fly $S$. mikii perceived the volatiles released from fungal fruiting bodies with high sensitivity. Especially, C. boleti showed consistent responses to 1-octen-3-ol as an important cue for host finding. Furthermore, excised antennae of $C$. boleti were employed as biocomponents in a biosensor. This new and promising testing method of wood durability against decay fungi provides fast and non-destructive measurements.

The characterisation of the physiological mechanisms utilised by C. boleti to detect host fungal volatiles may be part of further studies. To investigate in detail the olfactory system of $C$. boleti experiments with single sensillum recording (SSR) should be performed. Moreover, transmission electron microscopy (TEM) of the different chemosensory sensilla will provide important information about the ultrastructure of these organs and therefore to their physiological functions. Moreover, SSR recording may discover if the two enantiomers of 1-octen-3-ol are perceived by different sensilla, leading to a possible application of enantiomer discrimination.

A further task could be also the development of a protein-based biosensor for detecting wood decay. It can be presumed that fungivorous insects express odorant receptors and odorant binding proteins with high sensitivity to the fungal odours. Such proteins could be immobilised on a conductive substrate and implemented in a biosensor, as recently proposed by Prof. Trowell (Trowell 2008) in an ongoing project where the olfactory receptors of Drosophila melanogaster are included in a biosensor for detecting food aroma compounds. 


\subsection{References}

Agelopoulos NG, Pickett JA. 1998. Headspace analysis in chemical ecology: Effects of different sampling methods on ratios of volatile compounds present in headspace samples. Journal of Chemical Ecology 24: 1161-1172.

Bruce A, Wheatley ER, Humphris NS, Hackett CC, Florence EJM. 2000. Production of volatile organic compounds by Trichoderma in media containing different amino acids and their effect on selected wood decay fungi. Holzforschung 54: 481-486.

Bruce A, Verrall S, Hackett AC, Wheatley ER. 2004. Identification of volatile organic compounds (VOCs) from bacterial and yeast causing growth inhibition of sapstain fungi. Holzforschung 58: 193-198.

Buzzini P, Martini A, Cappelli F, Pagnoni UM, Davoli P. 2003. A study on volatile organic compounds (VOCs) produced by tropical ascomycete yeast. Antonie von Leeuwenhoek 84: 301-311.

Byers JA. 1995. Host tree chemistry affecting colonization in bark beetles. In: Carde RT, Bell WJ (Eds). Chemical Ecology of Insects 2. Chapman and Hall, New York. pp. 154-213.

Chang ST, Miles GP. 2004. Mushrooms: Cultivation, nutritional value, medicinal effect and environmental impact, $2^{\text {nd }}$ edition. Chapter 4: Overview of the biology of fungi. CRC Press, New York. pp. 53-144.

Chitarra GS, Abee T, Rombouts FM, Posthumus MA, Diijksterhuis J. 2004. Germination of Penicillium paneum conidia is regulated by 1 -octen-3-ol, a volatile self-inhibitor. Applied and Environmental Microbiology 70: 2823-2829.

Carroll GC, Wicklow DT. (Eds). 1992. The fungal community, its organization and role in the ecosystem vol. 9, Marcel Dekker, New York.

Curling SF, Clausen CA, Winandy JE. 2002. Relationships between mechanical properties, weight loss, and chemical composition of wood during incipient brown-rot decay. Forest Products Journal 52: 34-39.

Current RW, Meyer MJ, Borgerding AJ. 2001. Rapid aqueous sample extraction of VOCs: effect of physical parameters. Talanta 55: 519-529.

Eaton RA, Hale MDC. 1993. Wood: decay, pests and protection. Chapman and Hall, London.

Ewen RJ, Jones PRH, Ratcliffe NM, Spencer-Phillips PTN. 2004. Identification by gas chromatography-mass spectrometry of the volatile organic compounds emitted from the wood-rotting fungi Serpula lacrymans and Coniophora puteana, and from Pinus sylvestris timber. Mycological Research 108: 806-814.

Fiedler K, Schütz E, Geh S. 2001. Detection of microbial volatile organic compounds (MVOCs) produced by moulds on various materials. International Journal of Hygiene and Environmental Health 204: 111-121.

Gao P, Korley F, Martin J. 2002. Determination of unique volatile metabolites produced by five Aspergillus species commonly found in problem buildings. American Industrial Hygiene Association Journal 63: 135-140.

Gao P, Martin J. 2002. Volatile metabolites produced by three strains of Stachybotrys chartarum cultivated on rice and gypsum board. Applied Occupational and Environment Hygiene 17: 430-436.

Goodell B, Nicholas DD, Schultz TP. (Eds). 2003. Wood deterioration and preservation: advances in our changing world. American Chemical Society, Washington DC. 
Green DW, Winandy JE, Kretschmann DE. 1999. Mechanical properties of wood. In: Wood Handbook: Wood as an Engineering Material. Gen. Tech. Rept. FPL-GTR-113. USDA Forest Serv., Forest Prod. Lab., Madison, Wisconsis.

Highley TL. 1999. Biodeterioration of wood. In: Wood Handbook: Wood as an Engineering Material. Gen. Tech. Rept. FPL-GTR-113. USDA Forest Serv., Forest Prod. Lab., Madison, Wisconsin.

Hill C. 2006. Wood Modification: Chemical, thermal and other processes. John Wiley \& Sons Ltd., West Sussex.

Hoff JA, Klopfenstein NB, McDonald GI, Tonn JR, Kim MS, Zambino PJ, Hessburg PF, Rogers JD, Peever TL, Carris LM. 2004. Fungal endophytes in woody roots of Douglas-fir (Pseudotsuga menziesii) and ponderosa pine (Pinus ponderosa). Forest Pathology 34: 255-271.

Jeleń HH. 2003. Use of solid phase microextraction (SPME) for profiling fungal volatile metabolites. Letters in Applied Microbiology 36: 263-267.

Kanaujia L, Kaissling E-E. 1985. Interaction of pheromone with moth antennae: adsorption, desorption and transport. Journal of Insect Physiology 31: 71-81.

Kües U. 2000. Life history and development processes in the basidiomycete Coprinus cinereus. Microbiology and Molecular Biology Reviews 64: 316-353.

Schütz S, Weißbecker B, Hummel HE, Apel K-H, Schmitz H, Bleckmann H. 1999a. Insect antennae as a smoke detector. Nature 398: 298-299.

Schütz S, Weißbecker B, Koch UT, Hummel HE. 1999b. Detection of volatiles released by diseased potato tubers using a biosensor on the basis of intact insect antennae. Biosensors \& Bioelectronics 14: 221-228.

Scotter MJ, Langford SV, Wilson FP, McEwan JM, Chambers TS. 2005. Real-time detection of common microbial volatile organic compounds from medically important fungi by Selected Ion Flow Tube-Mass Spectrometry (SIFT-MS). Journal of Microbiological Methods 63: 127-134.

Sevonkaev I, Katz E. 2007. Biosensors based on immobilized insect fragments. Journal of Solid State Electrochemistry 12: 7-14.

Steinbrecht RA, Kasang G. 1972. Capture and conveyance of odour molecules in an insect olfactory receptor. In: Olfaction and taste IV. Schneider D (Ed). Wissenschaftliche Verlagsgesellschaft, Stuttgart. pp. 193-199.

Strobel GA, Dirkse E, Sears J, Markworth C. 2001. Volatile antimicrobials from Muscodor albus, a novel endophytic fungus. Microbiology 147: 2943-50.

Strobel G, Daisy B. 2003. Bioprospecting for microbial endophytes and their natural products. Microbiology and Molecular Biology Reviews 67: 491-502.

Thakeow P, Weißbecker B, Schütz S. 2006. Volatile organic compounds emitted from fungalrotting beech (Fagus sylvatica). Mitteilungen der Deutschen Gesellschaft für allgemeine und angewandte Entomologie 15: 157-160.

Thakeow P, Holighaus G, Schütz S. 2007. Volatile compounds for wood assessment. In: Kües U. (Ed). Wood production, wood technology and biotechnological impacts. Universitätsverlag Göttingen, Göttingen. pp. 197-228.

Thakeow P, Angeli, S, Weißbecker B, Schütz S. 2008. Antennal and behavioural responses of Cis boleti to fungal odour of Trametes gibbosa. Chemical Senses 33: 379-387.

Trowell S. "The Flagship Cybernose project" for quality biosensors for the Food Futures National Research Flagship of the Australian National University. http://www.csiro.au/partnerships/ps241.html (verified 20/01/08). 
Wheatley R, Hackett C, Bruce A, Kundzewicz A. 1997. Effect of substrate composition on production of volatile organic compounds from Trichoderma spp. inhibitory to wood decay fungi. International Biodeterioration and Biodegradation 39: 199-205.

Wilcox WW. 1978. Review of literature on the effects of early stages of decay on wood strength. Wood and Fiber Science Journal 9: 252-257.

Wu S, Zorn H, Krings U, Berger RG. 2005. Characteristic volatiles from young and aged fruiting bodies of wild Polyporus sulfureus (Bull.: Fr.) Fr. Journal of Agriculture and Food Chemistry 53: 4524-4528.

Yang X, Chen Q, Zhen J, Zhang JS, Shaw CY. 2001. Effects of environmental and test conditions on VOC emission from "wet" coating materials. Indoor air 11: 270-278.

Zabel RA, Morrel JJ. 1992. Wood Microbiology: Decay and its prevention. Academic press, Inc., New York.

Zeppa S, Gioacchini MA, Guidi C, Cuescini M, Pierleni R, Zambonelli A, Stocchi V. 2004. Determination of specific volatile organic compounds synthesised during Tuber borchii fruit body development by solid-phase microextraction and gas chromatography/mass spectrometry. Rapid Communications in Mass Spectrometry 18: 199-205.

Zhang Z, Pawliszyn J. 1993. Headspace solid phase microextraction. Analytical Chemistry 65: 1843-1852. 
Curriculum Vitae 


\section{CURRICULUM VITAE}

\section{Personal Data}

Name: Ms. Prodpran Thakeow

Place $\&$ date of birth: Chiangkham, Phayao, Thailand, 20 th August 1973

Working place: Department of Product Development Technology, Faculty of Agro-Industry, ChiangMai University, 50100 Thailand

Telephone: +66-53-948230-3

Home Address: $\quad 99$ Mu 7, Yuan, Chiangkham, Phayao 56110 Thailand

e-mail: ㅎthakeo@gwdg.de, prodpran@chiangmai.ac.th

\section{Educational qualifications}

\section{PhD degree}

(Oct 03- Mar 08)

Master degree

(Jun 97-Oct 00)

Bachelor degree

(Jun 92- Apr 96)

High school

(May 86- Mar 92)

Primary school

(May 80- Mar 86)
Wood biology and technology $\mathrm{PhD}$ program

Institute of Forest Zoology and Forest Conservation

George-August-University Göttingen, Germany

Dissertation: Development of a basic sensor system for wood degradation using volatile organic compounds Supervisor: Prof. Dr. Stefan Schütz

Petrochemistry and polymer science, Faculty of Science

Chulalongkorn University, Thailand

Thesis: Chemical modification of cassava starch for tensile properties of degradable polyethylene sheets

Supervisor: Prof. Dr. Suda Kiatkamjornwong

Chemistry, ChiangMai University, Thailand

Chiangkham wittayakhom, Phayao, Thailand

Piyamitr-wittaya, Phayao, Thailand 


\section{Working experience}

2002-Present Lecturer, Department of Product Development, Faculty of AgroIndustry, ChiangMai University, Thailand

2003-2008 PhD student, Institute of Forest Zoology and Forest Conservation, Georg-August-University Göttingen, Göttingen, Germany

2000-2002 Research and development engineer, Pacific Insulating Material (Thailand) Ltd.

1996-1997 Factory logistic staff, Lever Brothers (Thailand) Pub. Ltd.

(Present: Unilever)

\section{Publications}

\section{International papers}

Thakeow P, Angeli, S, Weißbecker B, Schütz S. 2008. Antennal and behavioural responses of Cis boleti to fungal odour of Trametes gibbosa. Chemical Senses 33: 379387.

Thakeow P, Weißbecker B, Schütz S. 2006. Volatile organic compounds emitted from fungal-rotting beech (Fagus sylvatica). Mitteilungen der Deutschen Gesellschaft für allgemeine und angewandte Entomologie 15: 157-160.

Kiatkamjornwong S, Thakeow P, Sonsuk M. 2001. Chemical modification of cassava starch for degradable polyethylene sheets. Polymer Degradation and Stability 73: 363375.

\section{Textbook}

Thakeow P, Holighaus G, Schütz S. 2007. Volatile compounds for wood assessment. In: Kües U. (Ed). Wood production, wood technology and biotechnological impacts. Universitätsverlag Göttingen, Göttingen. pp. 197-228. 


\section{Oral presentations}

Thakeow P, Schütz S. Insect Antennae as Promising Biosensors for Wood-rotting Fungi. Cost Action E37 (sustainability through new technologies for enhanced wood durability) Workshop in Braşov, Romania. 17-19 June 2007.

Thakeow P, Angeli S, Weißbecker B, Schütz S. Assessment of Fungivorous Insect Antennae as Biosensors for Detecting Wood Rotting Fungi. 17th Congress of European Chemoreception Organization, Granada, Spain. 4-8 September 2006.

Thakeow P, Chaisaena W, Kües U, Schütz S. Investigation of volatile organic compounds emitted by Coprinopsis cinerea. VAAM conference, Jena, Germany. 19-22 March 2006.

Thakeow P, Weißbecker B, Schütz S. Volatile organic compounds emitted from fungalrotting beech (Fagus sylvatica). Entomologentagung Dresden (DGaaE), Dresden, Germany. 21-24 March 2005.

Thakeow P, Schütz S. Volatile organic compounds (VOCs) as indicators in testing resistance against Basidomycetes. Cost Action E37 (sustainability through new technologies for enhanced wood durability) Workshop in Reinbeck, Germany. 8-9 November 2004.

\section{Posters}

Thakeow P, Angeli S, Weißbecker B, Schütz S. 1-Octen-3-ol as an important cue in fungal host finding of Cis boleti. 23 ${ }^{\text {rd }}$ International Congress of Entomology (ICE), Durban, South Africa. 6-12 July 2008.

Thakeow P, Angeli S, Ripon S, Simapaisan P, Thanapornpoonpong S, Schütz S. Volatile Organic Compounds of Thai Aroma Rice. 17th Congress of European Chemoreception Organization, Granada, Spain. 4-8 September 2006.

Thakeow P, Schütz S. Volatile organic compounds of wood-rot fungi metabolites. VAAM-Workshop; Stoffwechsel der Pilze. Fachhochschule Lausitz, Germany. 1618 September 2004. 


\section{Abstract}

Thakeow P, Angeli S, Wießbecker B, Schütz S. 2006. Assessment of fungivorous insect antennae as biosensors for detecting wood rotting fungi. Chemical Senses 31 (8), E67.

Thakeow P, Angeli S, Ripon S, Simapaisan P, Thanapornpoonpong S, Schütz S. 2006. Volatile organic compounds of Thai aroma rice. Chemical Senses 31 (8), E63.

Thakeow P, Chaisaena W, Kües U, Schütz S. 2006. Investigation of volatile organic compounds emitted by Coprinopsis cinerea. Biospekturm-Tagungsband p. 66.

Thakeow P, Weißbecker B, Schütz, S. Volatile organic compounds emitted from fungalrotting beech (Fagus sylvatica). Entomologentagung Dresden (DGaaE), 21-24 March 2005.

\section{Awards}

- The Royal Thai Government

- Grants from the European Chemoreception Research Organization (ECRO)

- Grants from COST Action E37

\section{Training course}

16 April - 11 May 2007 Workshop on pheromone measurement by field EAG by Prof. Dr. Uwe T. Koch

Technical University Kaiserslautern 